US Army Corps

of Engineers

Prepared for the U.S. Army Corps of Engineers, Portland District,

under an Interagency Agreement with the U.S. Department of Energy

Contract DE-AC05-76RL01830

\title{
Survival and Passage of Juvenile Chinook Salmon and Steelhead Passing Through Bonneville Dam, 2010
}

\section{Final Report}

GR Ploskey

MA Weiland

JS Hughes

CM Woodley

Z Deng

TJ Carlson

$\mathrm{J}$ Kim
IM Royer

GW Batten

AW Cushing

SM Carpenter

DJ Etherington

DM Faber

ES Fischer
$\mathrm{T} \mathrm{Fu}$

MJ Hennen

TD Mitchell

TJ Monter

JR Skalski

RL Townsend

SA Zimmerman

December 2011

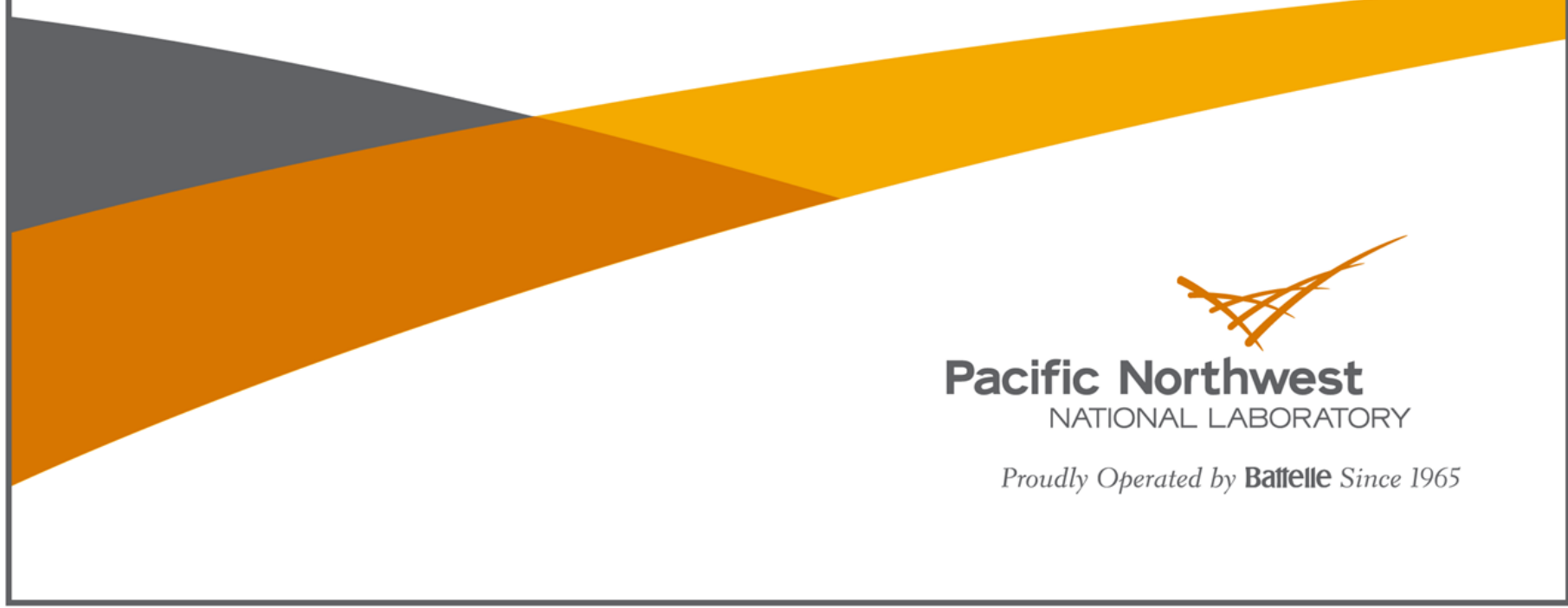




\section{DISCIAAIMER}

This report was prepared as an account of work sponsored by an agency of the United States Government. Neither the United States Government nor any agency thereof, nor Battelle Memorial Institute, nor any of their employees, makes any warranty, express or implied, or assumes any legal liability or responsibility for the accuracy, completeness, or usefulness of any information, apparatus, product, or process disclosed, or represents that its use would not infringe privately owned rights. Reference herein to any specific commercial product, process, or service by trade name, trademark, manufacturer, or otherwise does not necessarily constitute or imply its endorsement, recommendation, or favoring by the United States Government or any agency thereof, or Battelle Memorial Institute. The views and opinions of authors expressed herein co not necessarily state or rellect those of the United States Government or any agency thereof

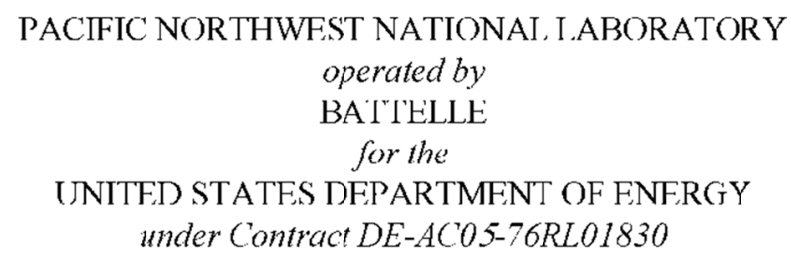

Printed in the United States of America

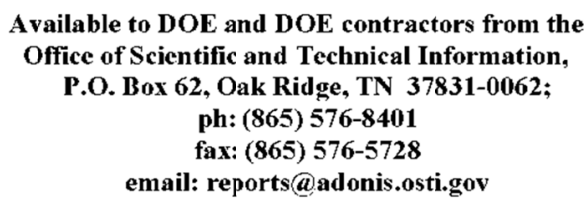

This document was printed on recycled paper. 
PNNL-20835

\section{Survival and Passage of Juvenile Chinook Salmon and Steelhead Passing Through Bonneville Dam, 2010}

\section{Final Report}

\author{
GR Ploskey \\ MA Weiland \\ JS Hughes \\ CM Woodley \\ Z Deng \\ TJ Carlson \\ J Kim
}

\author{
IM Royer \\ GW Batten \\ AW Cushing ${ }^{1}$ \\ SM Carpenter \\ DJ Etherington \\ DM Faber \\ ES Fischer
}

$\mathrm{T} \mathrm{Fu}$

MJ Hennen

TD Mitchell ${ }^{1}$

TJ Monter ${ }^{1}$

JR Skalski

RL Townsend ${ }^{2}$

SA Zimmerman

December 2011

Prepared for the U.S. Army Corps of Engineers Portland District, under an Interagency Services Agreement with the U.S. Department of Energy Contract DE-AC05-76RL01830

Pacific Northwest National Laboratory

Richland, Washington 99352

\footnotetext{
${ }^{1}$ Pacific State Marine Fisheries Commission, Portland, Oregon.

${ }^{2}$ Columbia Basin Research, University of Washington, Seattle, Washington.
} 


\begin{abstract}
Pacific Northwest National Laboratory (PNNL) and subcontractors conducted an acoustic-telemetry study of juvenile salmonid fish passage and survival at Bonneville Dam in 2010. The study was conducted to assess the readiness of the monitoring system for official compliance studies under the 2008 Biological Opinion and Fish Accords and to assess performance measures including route-specific fish passage proportions, travel times, and survival based upon a single-release model. This also was the last year of evaluation of effects of a behavioral guidance structure installed in the Powerhouse 2 forebay. The study relied on releases of live Juvenile Salmon Acoustic Telemetry System tagged smolts in the Columbia River and used acoustic telemetry to evaluate the approach, passage, and survival of passing juvenile salmon. This study supports the U.S. Army Corps of Engineers continual effort to improve conditions for juvenile anadromous fish passing through Columbia River dams.
\end{abstract}




\section{Preface}

The U.S. Army Corps of Engineers (USACE) Portland District, contracted with the Pacific Northwest National Laboratory (PNNL), in Richland, Washington, to conduct an acoustic-telemetry survival study at the Bonneville Dam in 2010. The PNNL assembled a study team consisting of staff from PNNL, the Pacific States Marine Fisheries Commission (PSMFC), and the University of Washington. The Portland District provided all funding and oversight.

This final report presents behavioral and fish passage results for tagged yearling and subyearling Chinook salmon smolts and juvenile steelhead as part of a survival study conducted at Bonneville Dam during 2010.

This report should be cited as follows:

Ploskey GR, MA Weiland, JS Hughes, CM Woodley, Z Deng, TJ Carlson, J Kim, IM Royer, GW Batten, AW Cushing, SM Carpenter, DJ Etherington, DM Faber, ES Fischer, T Fu, MJ Hennen, TD Mitchell, TJ Monter, JR Skalski, RL Townsend, and SA Zimmerman. 2011. Survival and Passage of Juvenile Chinook Salmon and Steelhead Passing Through Bonneville Dam, 2010. PNNL-20835, Final Report, Pacific Northwest National Laboratory, Richland, Washington. 


\section{Executive Summary}

Researchers at the Pacific Northwest National Laboratory collaborated with others at the Pacific States Marine Fisheries Commission, U.S. Army Corps of Engineers Portland District, and the University of Washington to conduct a 2010 study primarily to estimate survival rates of subyearling and yearling Chinook salmon smolts and juvenile steelhead passing through 1) the Bonneville Dam forebay, 2) the forebay, dam, and $81 \mathrm{~km}$ of tailwater, and 3) through the dam and its various routes and $81 \mathrm{~km}$ of tailwater. The study also estimated additional passage performance measures, most of which were stipulated in the Columbia Basin Fish Accords, evaluated affects of two spill treatments on passage and survival metrics, and evaluated the performance of the behavioral guidance structure (BGS) in the Powerhouse 2 (B2) forebay.

The 2010 study was not an official compliance test as described by the 2008 Federal Columbia River Power System Biological Opinion, because passage conditions for the dam had not been finalized. The Powerhouse 1 (B1) sluiceway was expanded for 2010 to roughly triple the amount of flow passing through surface-flow outlets from the B1 forebay, but flow was not accurately measured in 2010 and some of the floating sluiceway gates were sticking during the fish passage season. In addition, regional fishery managers wanted to add one more year of evaluation of a BGS installed in the B2 forebay. Managers also wanted to evaluate the effects of two spill treatments on fish-passage metrics and survival in summer 2010. One spill treatment consisted of a 24-h 95,000-cfs spill and the other consisted of 85,000 -cfs day and 120,000-cfs night spill. Unit 11, which is adjacent to the Bonneville Powerhouse 2 Corner Collector (B2CC) and critical for proper functioning of that surface-flow outlet, was out of service throughout 2010. The Portland District also wanted researchers to evaluate the performance of two independent cabled arrays deployed on every dam face (B1, the spillway, and B2) to make certain that the arrays would be ready for an official compliance test in 2011.

Acoustically tagged subyearling and yearling Chinook salmon smolts and juvenile steelhead released in the Columbia River upstream of John Day Dam (near Arlington, Oregon), in The Dalles tailrace, and in the tailwater near Hood River, Oregon, that were detected either at the Bonneville Dam forebay entrance array or at the face of the dam were available to form virtual releases. Single-release passage-survival estimates were made for fish passing through two river reaches: 1) the dam and $81 \mathrm{~km}$ of tailwater and 2 ) the forebay, dam, and $81 \mathrm{~km}$ of tailwater. Releases of live acoustically tagged fish at three sites upstream of Bonneville Dam totaled 3880 yearling Chinook salmon and 3885 juvenile steelhead in spring and 4449 subyearling Chinook salmon in summer. These tagged fish were released to support passage survival studies at John Day Dam, The Dalles Dam, and Bonneville Dam in 2010. The Juvenile Salmon Acoustic Telemetry System tag model number ATS-156dB, weighing $0.438 \mathrm{~g}$ in air, was used in this investigation.

This report provides a comprehensive summary of 2010 results, including route-specific passage survival estimates. Dam-passage survival to the Bonneville tailrace could not be estimated in 2010 because there were no reference releases of fish in the Bonneville tailrace or tailwater. Forebay to tailrace survival could not be estimated for the same reason.

The study results are summarized in the following tables. 
Table ES.1. Estimates of Single-Release, Tag-Life-Corrected Estimates of Dam-Passage Survival at Bonneville Dam in 2010

\begin{tabular}{|c|c|c|c|}
\hline & \multicolumn{3}{|c|}{ Passage Survival (dam and $81 \mathrm{~km}$ of tailwater) } \\
\hline Duration & $\begin{array}{l}\text { Yearling Chinook } \\
\text { Salmon }\end{array}$ & Steelhead & $\begin{array}{l}\text { Subyearling Chinook } \\
\text { Salmon }\end{array}$ \\
\hline 2010 & $0.952(\mathrm{SE}=0.0040)$ & $0.945(\mathrm{SE}=0.0043)$ & $0.958(\mathrm{SE}=0.0055)^{(\mathrm{a})}$ \\
\hline $\begin{array}{l}\text { During } 24-\mathrm{h} 95,000-\mathrm{cfs} \\
\text { Spill }(7 / 2 \text { to } 7 / 18)^{(\mathrm{b})}\end{array}$ & & & $0.926(\mathrm{SE}=0.0089)$ \\
\hline $\begin{array}{c}\text { During 85,000-cfs Day and } \\
\text { 120,000-cfs Night Spill } \\
(7 / 2 \text { to } 7 / 18)^{(b)} \\
\end{array}$ & & & $0.903(\mathrm{SE}=0.0111)$ \\
\hline \multicolumn{4}{|c|}{$\begin{array}{l}\text { The survival estimate for the entire summer study was based on virtual releases of fish regrouped from } \\
\text { The Dalles tailrace and Hood River, Oregon, releases only because virtual release survival for fish } \\
\text { released upstream of John Day and The Dalles dams near Roosevelt, Washington, was significantly } \\
\text { lower than that of fish releases in the Bonneville pool. } \\
\text { Survival estimates for the two spill treatments were based on virtual releases of fish regrouped from } \\
\text { all upstream release sites to maximize power to detect differences. Pooled estimates were pooled over } \\
\text { the period of time in which spill treatments were as prescribed. }\end{array}$} \\
\hline
\end{tabular}

Table ES.2. Fish Accords Performance Measures at Bonneville Dam in 2010

\begin{tabular}{lccc}
\hline \multicolumn{1}{c}{ Performance Measures } & $\begin{array}{c}\text { Yearling Chinook } \\
\text { Salmon }\end{array}$ & Steelhead & $\begin{array}{c}\text { Subyearling Chinook } \\
\text { Salmon }^{(\mathrm{a})}\end{array}$ \\
\hline $\begin{array}{l}\text { Forebay Entrance Array to } \\
\text { rkm 153 Survival }\end{array}$ & $0.951(\mathrm{SE}=0.0040)$ & $0.944(\mathrm{SE}=0.0043)$ & $0.956(\mathrm{SE}=0.0054)$ \\
$\begin{array}{l}\text { Forebay Residence Time (h) } \\
\text { (Median; Mean) }\end{array}$ & $0.74 ; 1.27(\mathrm{SE}=0.046)$ & $1.69 ; 4.22(\mathrm{SE}=0.112)$ & $0.69 ; 1.14(\mathrm{SE}=0.042)$ \\
$\begin{array}{l}\text { 100-m Forebay Residence } \\
\text { Time (h) (Median; Mean) }\end{array}$ & $0.18 ; 1.84(\mathrm{SE}=0.267)$ & $1.43 ; 6.06(\mathrm{SE}=0.566)$ & $0.13 ; 1.00(\mathrm{SE}=0.164)$ \\
$\begin{array}{l}\text { Tailrace Egress Time (h) } \\
\text { (Median; Mean) }\end{array}$ & $0.46 ; 0.94(\mathrm{SE}=0.104)$ & $0.41 ; 1.12(\mathrm{SE}=0.135)$ & $0.42 ; 1.45(\mathrm{SE}=0.259)$ \\
$\begin{array}{l}\text { Project Passage Time (h) } \\
\text { (Median; Mean) }\end{array}$ & $1.29 ; 2.21(\mathrm{SE}=0.114)$ & $2.40 ; 5.32(\mathrm{SE}=0.177)$ & $1.26 ; 2.58(\mathrm{SE}=0.245)$ \\
$\begin{array}{l}\text { Spill-Passage Efficiency } \\
\text { (SPE) }\end{array}$ & $0.528(\mathrm{SE}=0.009)$ & $0.406(\mathrm{SE}=0.009)$ & $0.524(\mathrm{SE}=0.009)$ \\
$\begin{array}{l}\text { Spill + B2CC Passage } \\
\text { Efficiency }\end{array}$ & $0.717(\mathrm{SE}=0.008)$ & $0.712(\mathrm{SE}=0.008)$ & $0.615(\mathrm{SE}=0.008)$ \\
\hline $\begin{array}{l}\text { (a) Subyearling Chinook values are for the entire summer study period } \\
\text { (b) SPE is the number of fish passing the spillway divided by the number passing the entire dam. } \\
\text { (c) Spill + B2CC passage efficiency is a metric specified by the 2008 Fish Accords. }\end{array}$ & \\
\hline
\end{tabular}


Table ES.3. Survival Study Summary

Year: 2010

Study Site(s): Bonneville Dam

Objective(s) of study: Estimate dam-passage survival for yearling Chinook salmon and steelhead and associated Fish Accords performance measures using a single-release survival model; evaluate whether the behavioral guidance structure (BGS) in the B2 forebay improved B2CC passage efficiency, and test two spill treatments to see which one improved subyearling Chinook salmon survival

Hypothesis $($ Null $=\mathrm{H} 0$; Alternative $=\mathrm{H} 1)$ :

H0: B2CC passage efficiency (2010 with B2 BGS) $\leq$ B2CC passage efficiency (2004 or 2005 without B2 BGS)

H1: B2CC passage efficiency (2010 with B2 BGS) >B2CC passage efficiency (2004 or 2005 without B2 BGS)

H0: Subyearling survival under $95 \mathrm{kcfs}$ summer spill $\leq$ survival under $85 \mathrm{kcfs}$ day $/ 120 \mathrm{kcfs}$ night spill

H1: Subyearling survival under $95 \mathrm{kcfs}$ summer spill $>$ survival under $85 \mathrm{kcfs}$ day $/ 120 \mathrm{kcfs}$ night spill

Fish: Species race:

Yearling Chinook salmon $(\mathrm{CH} 1)$

Juvenile steelhead (STH)

subyearling Chinook salmon (CH0)

\begin{tabular}{lccc|lrrr}
\hline Size (median): & CH1 & STH & CH0 & Sample Size: & CH1 & STH & CH0 \\
Weight (g): & 31.4 & 78.1 & 12.4 & \# release sites: & 3 & 3 & 3 \\
Length (mm): & 152.0 & 214.0 & 110.0 & \# releases & 94 & 94 & 96 \\
& & & & Total \# released: & 3880 & 3885 & 4449 \\
\hline Tag: & & Analytical Model: & Characteristics of Estimate: & & \\
Type/model: Advanced & Virtual/single release & Effects Reflected (direct, total, etc.): Direct & \\
Telemetry Systems (ATS)- & & & Absolute or Relative: & Relative & \\
156dB & & & & & \\
Weight (gm): 0.438 g (air) & & & & &
\end{tabular}

Environmental/Operating Conditions (daily from April 28 through July 18):

Discharge (kcfs): mean 246.4, minimum 156.0, maximum 397.7

Temperature $\left({ }^{\circ} \mathrm{C}\right.$ - scroll case): mean 15.0 , minimum 11.1 , maximum 19.4

Total Dissolved Gas (tailrace): mean $111.5 \%$, minimum $104.8 \%$, maximum $117.4 \%$

Treatment(s): $95 \mathrm{kcfs}$ spill and $85 \mathrm{kcfs}$ spill during the day and $120 \mathrm{kcfs}$ overnight from July 2-19, 2010

Unique Study Characteristics: Turbine Unit 11 was offline all year and turbine 13 operated very little in summer; first year B1 sluiceway was widened for increased discharge; the B2 BGS was installed in the B2 forebay; turbine intake extensions were installed at every other intake on north half of B2 (15A, 15C, 16B, 17A, 17C, 18B).

Survival and Passage

Estimates:

Survival: Forebay entrance array (CR236) to CR153

Survival: Dam face to the primary array (CR153)

Forebay Residence Time (h)

(median; mean)

100-m Forebay Residence

Time (h)

(median; mean)

$\begin{array}{ccc}\text { Yearling Chinook } & \text { Steelhead } & \text { Subyearling Chinook } \\ 0.951(\mathrm{SE}=0.0040) & 0.944(\mathrm{SE}=0.0043) & 0.956(\mathrm{SE}=0.0054) \\ 0.952(\mathrm{SE}=0.0040) & 0.945(\mathrm{SE}=0.0043) & 0.958(\mathrm{SE}=0.0055) \\ 0.74 ; 1.27(\mathrm{SE}=0.046) & 1.69 ; 4.22(\mathrm{SE}=0.112) & 0.69 ; 1.14(\mathrm{SE}=0.042) \\ 0.18 ; 1.84(\mathrm{SE}=0.267) & 1.43 ; 6.06(\mathrm{SE}=0.566) & 0.13 ; 1.00(\mathrm{SE}=0.164) \\ & & \end{array}$


Table ES.3. (contd)

\begin{tabular}{|c|c|c|c|}
\hline Estimates: & Yearling Chinook & Steelhead & Subyearling Chinook \\
\hline & $46.094(\mathrm{SF}=0.10$ & $11 \cdot 112(\mathrm{SF}=0$ & $042 \cdot 145(\mathrm{SE}=0259)$ \\
\hline Time $(\mathrm{Cl}$ & $(\mathrm{SE}=($ & $40 ; 5.32(\mathrm{SE}=0.177)$ & $1.26 ; 2.58(\mathrm{SE}=0.245)$ \\
\hline fficiency & & & \\
\hline mincicicy & & & \\
\hline \multicolumn{4}{|c|}{$\begin{array}{l}\text { Results: This was not an official compliance test requiring paired reference releases, but single-release estimates } \\
\text { for yearling Chinook salmon still exceeded the } 2008 \text { Biological Opinion (BiOp) requirement of } 0.96 \text {, and single- } \\
\text { release estimates for steelhead were very close to the BiOp requirement and may have met the requirement had } \\
\text { there been official reference releases to produce absolute survival estimates. Spill-passage efficiency was as high as } \\
\text { or higher than previously reported for radio-telemetry and fixed aspect hydroacoustic studies. The B2 behavioral } \\
\text { guidance structure installed in } 2008,2009 \text {, and } 2010 \text { increased the B2CC passage efficiency of yearling Chinook } \\
\text { salmon by about } 12.5 \% \text { over } 2004 \text { and } 2005 \text { estimates, but benefits were not obvious for juvenile steelhead or } \\
\text { subyearling Chinook salmon. A one-tailed paired t-test indicated that mean dam passage survival was significantly } \\
\text { higher }(\mathrm{P}=0.047) \text { for subyearling Chinook salmon during the } 95 \text {-kcfs spill treatment }(0.926) \text { than it was during the } \\
85 \mathrm{kcfs} \text { day } / 120 \mathrm{kcfs} \text { night spill treatment }(0.887) \text {. However, the calculated mean for the } 85 \mathrm{kcfs} \text { day and } 120 \mathrm{kcfs} \\
\text { night treatment }(0.887) \text { was biased low by one point estimate on } 7 / 15 \text { (survival }=0.713 ; \mathrm{n}=48) \text { relative to the } \\
\text { pooled estimate for the season treatment }(0.903) \text {. The } 1 / 295 \% \text { confidence intervals for the two pooled estimates of } \\
0.926 \text { ( } 95 \text {-kcfs treatment) and } 0.903(85 / 120-\mathrm{kcfs} \text { treatment) overlapped, suggesting that those pooled estimates did } \\
\text { not differ significantly between the treatments. }\end{array}$} \\
\hline
\end{tabular}




\section{Acknowledgments}

This study was the result of hard work by dedicated scientists from the Pacific Northwest National Laboratory (PNNL), Pacific States Marine Fisheries Commission (PSMFC), the U.S. Army Corps of Engineers (USACE) Portland District, and the University of Washington (UW). Their teamwork and attention to detail, schedule, and budget were essential for the study to succeed in providing high-quality results to decision-makers.

- PNNL: T Abel, C Arimescu, G Batten, R Brown, S Carpenter, J Carter, K Carter, E Choi, K Deters, G Dirkes, D Faber, E Fischer, T Fu, G Gaulke, M Gay, K Hall, K Ham, R Harnish, M Hennen, M Hughes, G Johnson, F Khan, J Kim, K Knox, B Lamarche, K Lavender, J Martinez, G McMichael, B Noland, E Oldenburg, G Ploskey, I Royer, N Tavan, S Titzler, N Trimble, M Weiland, C Woodley, and $\mathrm{S}$ Zimmerman

Susan Ennor edited this report and Kathy Neiderhiser formatted it.

- UW, CBR: J Lady, A Seaburg, and P Westhagen

- PSMFC: R Martinson (Supervisor), G Kolvachuk (JDA SMF), Dean Ballinger (BON SMF), C Anderson, A Cushing, D Etherington, G George, S Goss, T Monter, T Mitchell, R Plante, M Walker, R Wall, M Wilberding

- USACE Portland District: B Eppard, M Langeslay, B Cordie, D Schwartz, M Zyndol, and electricians, operators, and biologists at John Day Dam, The Dalles Dam, and Bonneville Dams. We particularly thank biologists at Bonneville Dam (J Rerecich, B Hausmann, and K Welch) that provided coordination between the research team and the project.

Advanced Telemetry Systems, Inc. (ATS) manufactured the acoustic tags. Autonomous and dammounted hydrophones were manufactured by Sonic Concepts, Seattle, Washington. Precision Acoustic Systems, also in Seattle, made the quad channel receivers and conducted node acceptance tests for PNNL. Cascade Aquatics, Inc. in Ellensburg, Washington, activated and delivered the acoustic tags. Schlosser Machine Shop fabricated anchors for autonomous nodes and frames for star clusters that were deployed in the spillway forebay. 


\section{Acronyms and Abbreviations}

\begin{tabular}{|c|c|}
\hline ATS & Advanced Telemetry Systems, Inc. ${ }^{\circledR}$ \\
\hline B1 & Bonneville Powerhouse 1 \\
\hline B2 & Bonneville Powerhouse 2 \\
\hline $\mathrm{B} 2 \mathrm{CC}$ & Bonneville Powerhouse 2 Corner Collector \\
\hline B2 JBS & Bonneville Powerhouse 2 Juvenile Bypass System \\
\hline BGS & behavior guidance structure \\
\hline $\mathrm{BiOp}$ & Biological Opinion \\
\hline $\mathrm{BON}$ & Bonneville Dam \\
\hline BPA & Bonneville Power Administration \\
\hline BRZ & boat restricted zone \\
\hline${ }^{\circ} \mathrm{C}$ & degree(s) Celsius or Centigrade \\
\hline $\mathrm{CF}$ & CompactFlash (card) \\
\hline $\mathrm{cfs}$ & cubic feet per second \\
\hline $\mathrm{CHO}$ & subyearling Chinook salmon \\
\hline $\mathrm{CH} 1$ & yearling Chinook salmon \\
\hline $\mathrm{CI}$ & confidence interval (95\%) \\
\hline CJS & Cormack-Jolly-Seber (model) \\
\hline CL & confidence limit $( \pm 1 / 295 \%)$ \\
\hline $\mathrm{cm}$ & centimeter(s) \\
\hline DART & Data Access in Real Time \\
\hline FCRPS & Federal Columbia River Power System \\
\hline $\mathrm{ft}$ & foot(feet) \\
\hline g & $\operatorname{gram}(\mathrm{s})$ \\
\hline gal & gallon(s) \\
\hline $\mathrm{g} / \mathrm{L}$ & gram(s) per liter \\
\hline GPS & global positioning system \\
\hline h & hour(s) \\
\hline in. & inch(es) \\
\hline JBS & Juvenile Bypass System \\
\hline JMF & Juvenile Monitoring Facility below the Second Powerhouse (B2) \\
\hline JSATS & Juvenile Salmon Acoustic Telemetry System \\
\hline $\mathrm{kcfs}$ & thousands of cubic feet per second \\
\hline $\mathrm{kg}$ & kilogram(s) \\
\hline $\mathrm{km}$ & kilometer(s) \\
\hline $\mathrm{L}$ & liter(s) \\
\hline $\mathrm{m}$ & meter \\
\hline
\end{tabular}




\begin{tabular}{|c|c|}
\hline $\mathrm{MCN}$ & McNary Dam \\
\hline $\mathrm{mg} / \mathrm{L}$ & milligram(s) per liter \\
\hline $\mathrm{mL}$ & milliliter(s) \\
\hline $\mathrm{mm}$ & millimeter(s) \\
\hline MOA & Memorandum of Agreement \\
\hline $\mathrm{m} / \mathrm{s}$ & meter(s) per second \\
\hline MS-222 & tricaine methanesulfonate \\
\hline MSL & mean sea level \\
\hline NOAA & National Oceanic and Atmospheric Administration \\
\hline PIT & passive integrated transponder \\
\hline PNNL & Pacific Northwest National Laboratory \\
\hline PSMFC & Pacific States Marine Fisheries Commission \\
\hline PTAGIS & Passive Integrated Transponder (PIT) Tag Information System \\
\hline PVC & polyvinyl chloride \\
\hline rkm & river kilometer \\
\hline RME & research, monitoring, and evaluation \\
\hline ROR & run-of-river \\
\hline RPA & Reasonable and Prudent Alternative \\
\hline$\mu \mathrm{s}$ & microsecond(s) \\
\hline $\mathrm{s}$ & second(s) \\
\hline SAS & Statistical Analysis System \\
\hline SE & standard error \\
\hline SPE & spill-passage efficiency \\
\hline STH & juvenile steelhead \\
\hline USACE & U.S. Army Corps of Engineers \\
\hline UW & University of Washington \\
\hline
\end{tabular}




\section{Contents}

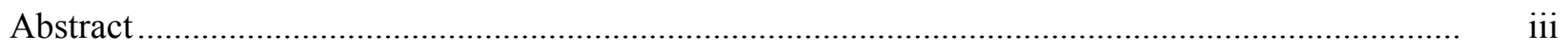

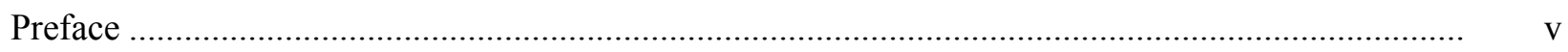

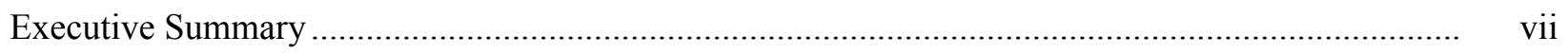

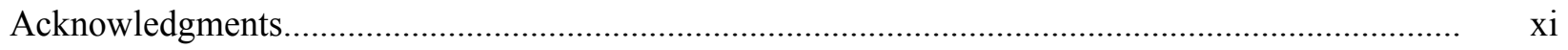

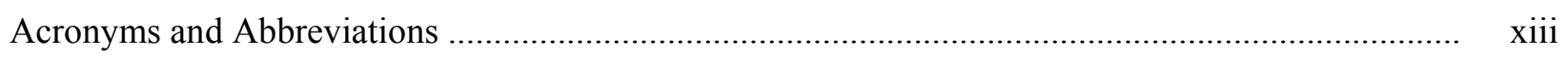

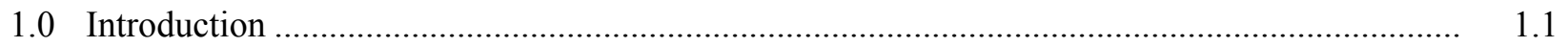

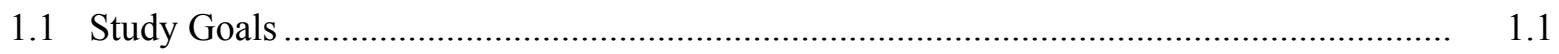

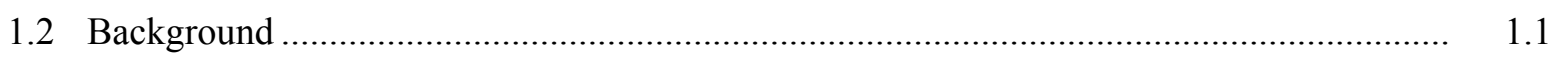

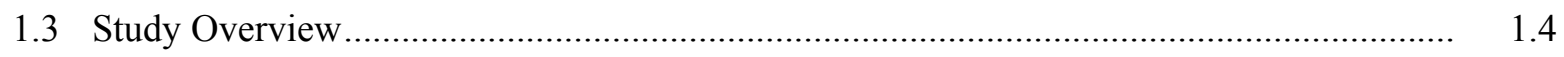

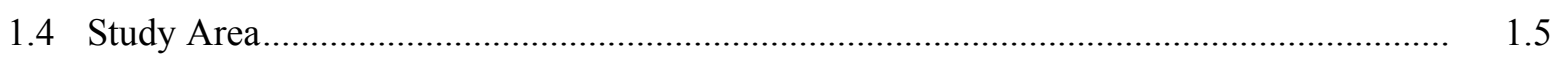

1.4.1 Bonneville Lock and Dam............................................................................. 1.5

1.4.2 Modeled River Discharge Relative to Historical Estimates ................................. 1.7

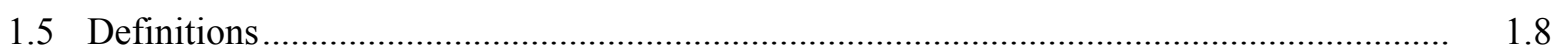

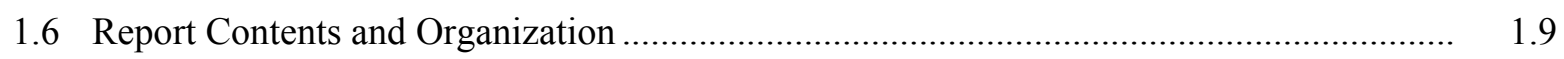

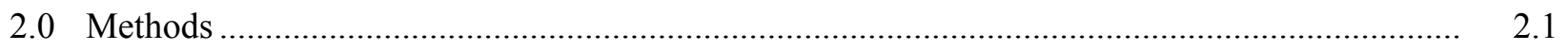

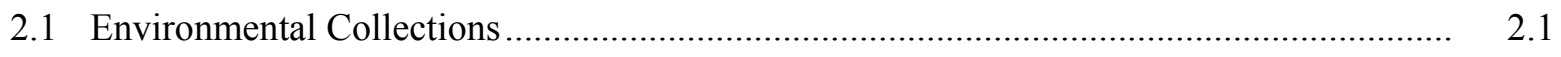

2.2 Release-Recapture Design and Sample Sizes ......................................................... 2.1

2.2.1 Federal and State Permitting .......................................................................... 2.2

2.2.2 Acoustic and PIT Tags .................................................................................. 2.3

2.3 The Collection and Tagging Site........................................................................... 2.3

2.4 Fish Collection, Tagging, and Holding ................................................................... 2.3

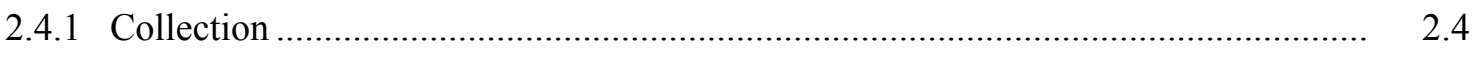

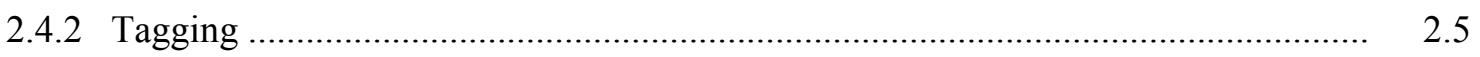

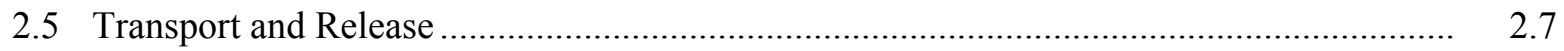

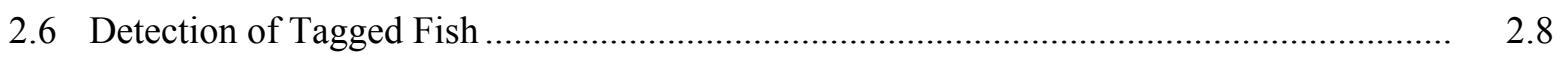

2.6.1 Cabled Dam-Face Arrays ......................................................................... 2.8

2.6.2 Autonomous Node Arrays.............................................................................. 2.12

2.6.3 Node Retrieval, Servicing, and Redeployment ................................................ 2.15

2.7 Project Discharge and Water Temperature .............................................................. 2.16

2.8 Acoustic Signal Processing ....................................................................................... 2.16

2.8.1 Binary Waveform Data Files......................................................................... 2.17

2.8.2 Filtering Decoded Data .............................................................................. 2.18

2.8.3 Tracking Fish Movements .............................................................................. 2.19

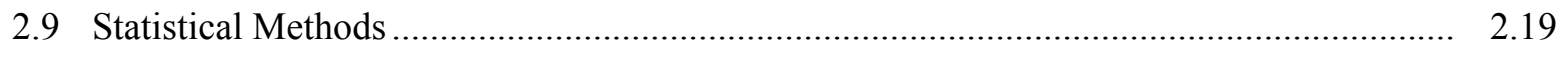

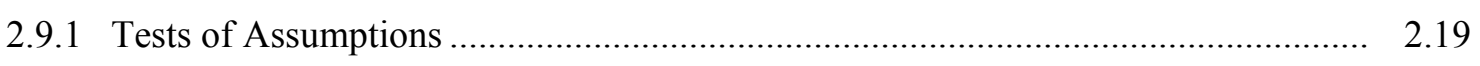

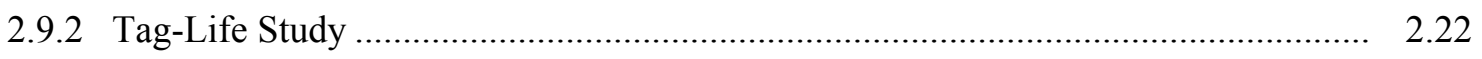




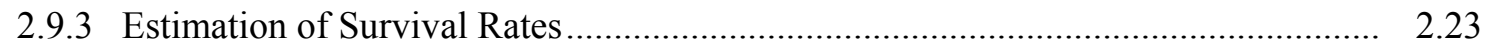

2.9.4 Estimation of Travel Times.......................................................................... 2.24

2.9.5 Estimation of Passage Efficiencies................................................................ 2.24

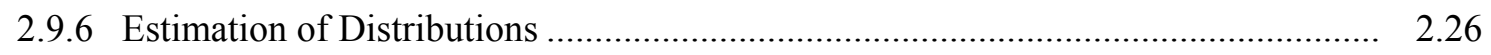

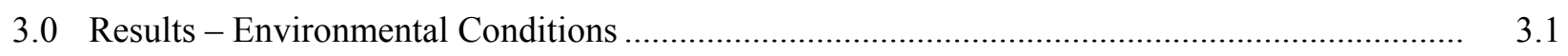

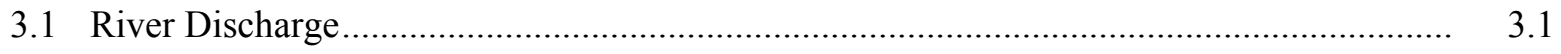

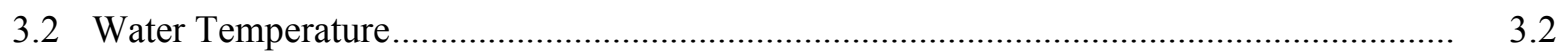

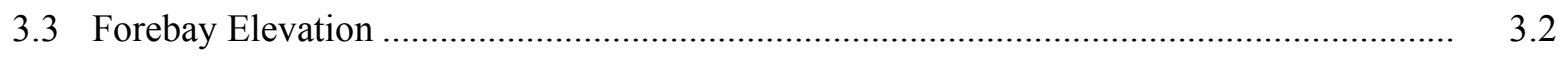

3.4 Summer Spill Treatments ....................................................................................... 3.3

4.0 Results - Yearling Chinook Salmon..........................................................................

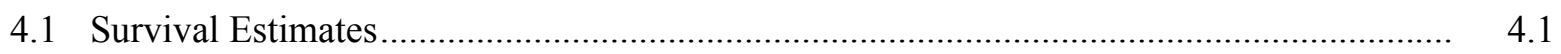

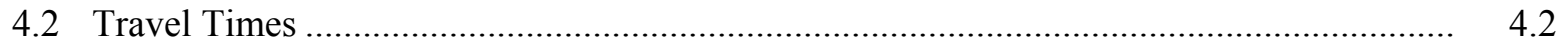

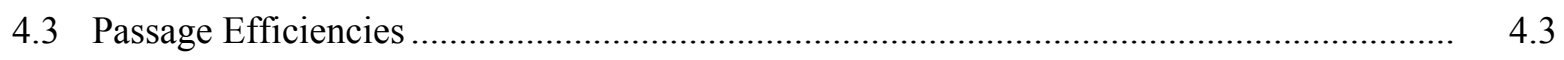

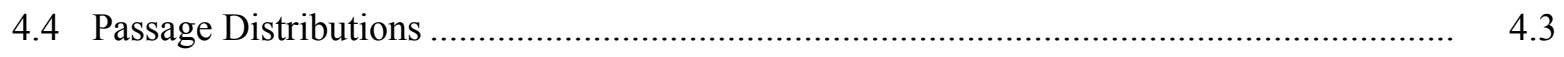

4.5 Effect of the B2 Behavioral Guidance System .......................................................... 4.4

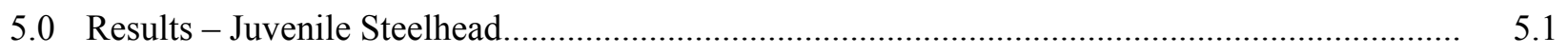

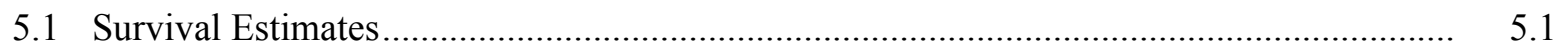

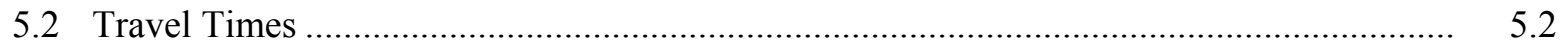

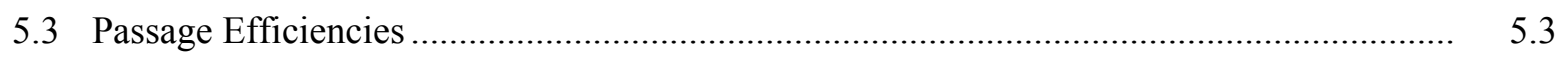

5.4 Passage Distributions ........................................................................................... 5.4

5.5 Effect of the B2 Behavioral Guidance System ............................................................ 5.5

6.0 Results - Subyearling Chinook Salmon ...................................................................... 6.1

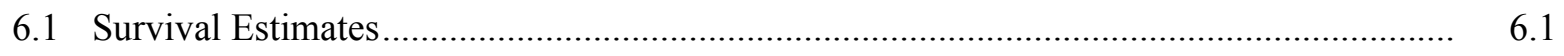

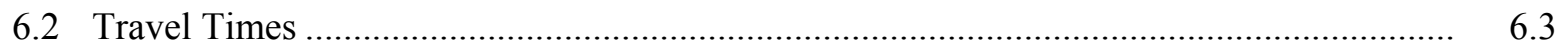

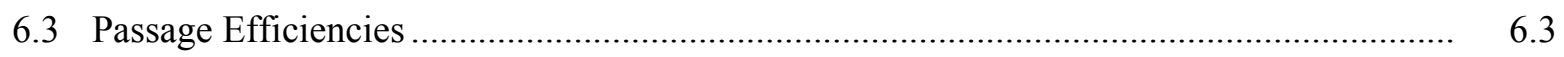

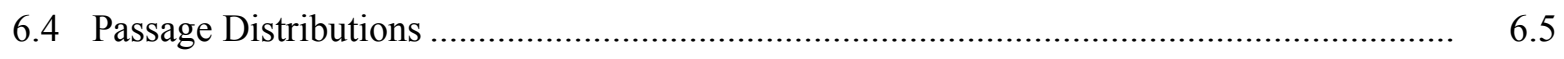

6.5 Effect of the B2 Behavioral Guidance System ........................................................... 6.6

6.6 Effects of Spill Treatments on Performance Metrics .................................................... 6.7

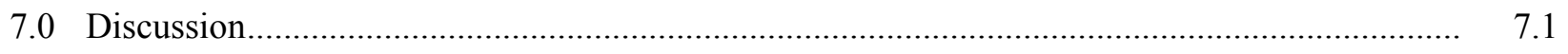

7.1 Statistical Performance and Survival Model Assumptions ............................................ 7.1

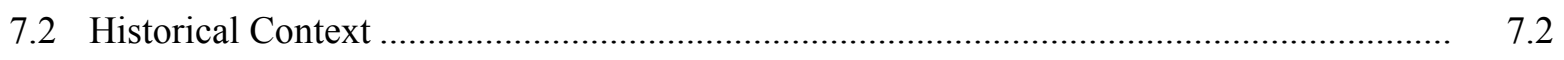

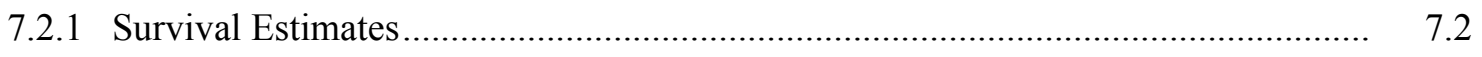

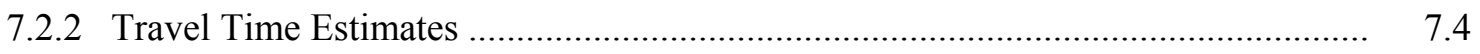

7.2.3 Passage-Efficiency Estimates.................................................................... 7.6

7.3 Day and Night Effects on Passage Metrics ................................................................. $\quad 7.6$

7.4 Effect of Spillway Discharge Treatments in Summer .................................................... 7.7

7.5 Performance of the B2 Behavior Guidance Structure ................................................... 7.8

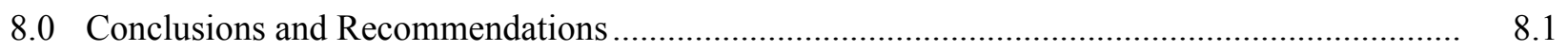

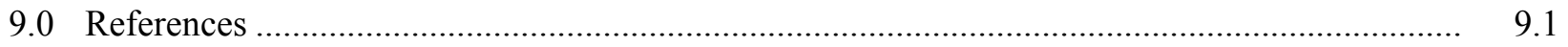


Appendix A - Fish-Tagging Tables

A. 1

Appendix B - Hydrophone and Autonomous Node Deployment Tables

B. 1

Appendix C - Capture Histories

C. 1

Appendix D - Detection and Survival Probabilities .

D.1

Appendix E - Assessment of Survival Model Assumptions ..

E.1 


\section{Figures}

1.1 Plan View of the Bonneville Dam Project ..................................................................... 1.6

1.2 The Behavioral Guidance Structure with One Section Shown out of the Water; and as Deployed in the Forebay of the Bonneville Dam Second Powerhouse ......................... 1.6

1.3 Bonneville Dam Study Area ........................................................................................... 1.7

1.4 Plot of Modeled Columbia River Discharge in the 2009-2010 Water Year and

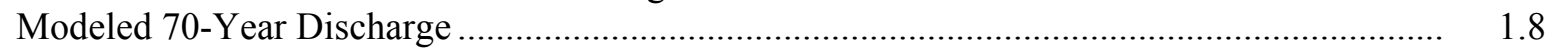

2.1 Schematic of the 2010 Study Design ......................................................................... 2.2

2.2 JSATS 0.43-g Acoustic Micro-Transmitter and PIT Tag Surgically Implanted in Yearling and Subyearling Chinook Salmon and Steelhead Smolts in 2010 ...

2.3 Surgical Implantation of Tags .................................................................................... 2.7

2.4 Post-Surgery Holding Tank with Recovery Buckets .......................................................... 2.7

2.5 Schematic of Dam-Face Receiver System Showing the Main Components and Direction of Signal Acquisition and Processing ................................................................. 2.9

2.6 Location of Hydrophones on the Dam Face and in the Immediate B1, B2, and Spillway Forebays of Bonneville Dam in 2010 ............................................................... 2.10

2.7 Four-Inch-Diameter Trolley Pipe Mounted on Piers at B2 ............................................... 2.11

2.8 Trolleys Used to Deploy Hydrophones at B1 and B2 and the Spillway ................................. 2.12

2.9 Front View Schematic of Hydrophone Deployments at Three Turbines Showing

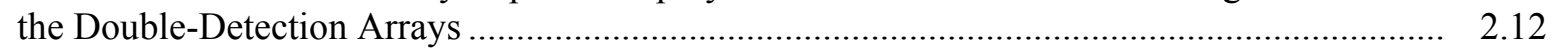

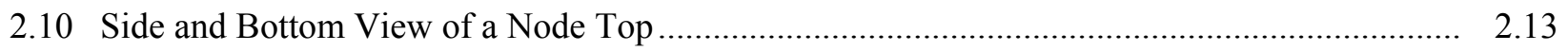

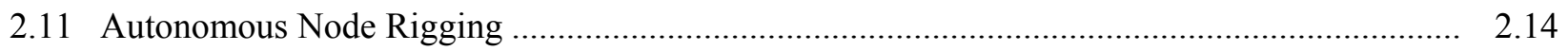

2.12 Locations of Autonomous Nodes in Study Arrays ............................................................. 2.15

2.13 Autonomous Node Retrieval.................................................................................... 2.16

2.14 Example of Time-Domain Waveforms and Corresponding Cross-Correlations Acquired at the John Day Dam Spillway....

3.1 Average Daily Water Discharge from Bonneville Dam During the 2010 Study and for the Preceding 10-Year Period.

3.2 Daily Outflow and Spill Discharge of Water from Bonneville Dam for the Period from April 26 Through June 13, 2010 and 10-Year Averages from 2000 Through 2009.

3.3 Bonneville Dam Average Daily Forebay Water Temperatures During the 2010 Study and for the Preceding 10-Year Period ................................................................................. 3.2

3.4 Bonneville Dam Hourly Estimates of Forebay Elevation ..................................................... 3.2

3.5 Plot of Spill Discharge Rate During Summer 2010 Showing Eight Successfully Realized Spill Treatment Blocks.

4.1 Horizontal Distribution of Yearling Chinook Salmon Passage in Spring 2010 ....................... 4.5

5.1 Horizontal Distribution of Juvenile Steelhead Passage in Spring 2010 ................................. 5.4

6.1 Plot of Virtual Single-Release Survival Estimates and 95\% Confidence Intervals for Subyearlings Released in The Dalles Tailrace and Near Hood River, Oregon Compared to an Estimate for Fish Released Near Roosevelt, Washington .... 
6.2 Horizontal Distribution of Subyearling Chinook Salmon Passage in Spring 2010 ................. 6.6

6.3 Plot of Subyearling Chinook Salmon Survival Rates by Spill Treatment Date ....................... 6.8

\section{Tables}

ES.1 Estimates of Single-Release, Tag-Life-Corrected Estimates of Dam Passage

Survival at Bonneville Dam in 2010

viii

ES.2 Fish Accords Performance Measures at Bonneville Dam in 2010.

viii

ES.3 Survival Study Summary

ix

1.1 Definitions of Performance Measures in This Study ....

1.8

2.1 Sample Sizes of Acoustic-Tag Releases Used in the 2010 Survival Study at Bonneville Dam

2.2 Number of Fish Rejected by Criteria During Spring and Summer Tagging at John Day Dam...

2.3 Relative Release Times for the Acoustic-Tagged Fish to Accommodate Downstream Mixing

4.1 Route-Specific Dam-Passage Survival Estimates for Yearling Chinook Salmon

4.2 Travel Times for Yearling Chinook Salmon

4.3 Passage Efficiencies for Yearling Chinook Salmon

4.4 Passage Percentage for Tagged Yearling Chinook Salmon Migrating Downstream Through B2CC and B2 Turbine Routes.

5.1 Route-Specific Dam-Passage Survival Estimates for Juvenile Steelhead

5.2 Travel Times for Juvenile Steelhead.

5.3 Passage Efficiencies for Juvenile Steelhead

5.4 Passage Percentage for Tagged Juvenile Steelhead Migrating Downstream Through $\mathrm{B} 2 \mathrm{CC}$ and B2 Turbine Routes ....

6.1 Route-Specific Dam-Passage Survival Estimates for Subyearling Chinook Salmon ...

6.2 Travel Times for Subyearling Chinook Salmon .

6.3 Passage Efficiencies for Subyearling Chinook Salmon

6.4 Passage Percentage for Tagged Subyearling Chinook Salmon Migrating Downstream Through B2CC and B2 Turbine Routes

6.5 Virtual Single-Release Dam-Passage Survival Estimates and 95\% Confidence Intervals by Spill Treatment in Summer 2010

6.6 Statistical Tests on Subyearling Chinook Salmon Survival by Spill Treatment.

6.7 Comparison of Subyearling Chinook Salmon Travel Time and Passage Metrics

Under the Two Summer Spill Treatments

7.1 Survival of Yearling Chinook Salmon that Passed Through Various Routes at Bonneville Dam in Some Years from 2002 Through 2010

7.2 Survival of Juvenile Steelhead that Passed Through Various Routes at Bonneville Dam in Some Years from 2004 Through 2010 
7.3 Survival of Subyearling Chinook Salmon that Passed Through Various Routes at Bonneville Dam in Some Years from 2004 Through 2010 .

7.4 Comparison of Passage-Efficiency Metric Estimates in 2010 Relative to Available Historical Ranges for Non-Drought Years... 


\subsection{Introduction}

In a continual effort to improve conditions for juvenile anadromous fish passing through Columbia River dams, the U.S. Army Corps of Engineers (USACE) Portland District has funded numerous evaluations of fish passage and survival. In 2010, researchers at the Pacific Northwest National Laboratory (PNNL) in collaboration with the Pacific States Marine Fisheries Commission (PSMFC), USACE, Portland District, and the University of Washington (UW), conducted this juvenile fish passage and survival study.

\subsection{Study Goals}

The primary goal of this study was to estimate the survival of yearling and subyearling Chinook salmon and juvenile steelhead passing through the dam by various routes and $81 \mathrm{~km}$ of tailwater using a single-release survival model. This effort provided the opportunity to evaluate the adequacy of the proposed monitoring system for conducting official compliance studies in future years. Additional passage performance measures stipulated by the Columbia Basin Fish Accords also were estimated, as were single-release estimates of route-specific survival rates. Performance measures included spill passage efficiency, forebay residence time, tailrace egress time, and project passage time. A behavioral guidance structure (BGS) was still installed in the Bonneville Powerhouse 2 (B2) forebay, and its effect on performance measures was evaluated as well in both seasons. A goal specific to the summer study was to evaluate effects of two spillway discharge treatments on survival rates and passage performance measures.

The 2010 study was not an official compliance test as described by the 2008 Federal Columbia River Power System (FCRPS) Biological Opinion (BiOp; NOAA 2008), because passage conditions for the dam had not been finalized. The Bonneville Powerhouse 1 (B1) sluiceway was expanded for 2010 to roughly triple the amount of flow passing through surface-flow outlets from the B1 forebay, but flow was not accurately measured in 2010 and some of the floating sluiceway gates were sticking during the fish passage season. Both of these conditions should be remedied for 2011. In addition, regional fishery managers wanted to add one more year of B2 behavioral guidance structure (BGS) evaluation and for summer 2010 wanted to evaluate effects of two spill treatments on fish-passage metrics and survival. Unit 11, which is adjacent to the Bonneville Powerhouse 2 Corner Collector (B2CC) and critical for proper functioning of that surface-flow outlet, was out of service throughout 2010. The USACE also wanted researchers to evaluate the performance of two independent cabled arrays deployed on every dam face (B1, the spillway, and B2) for detecting and tracking fish to make certain that the arrays would be ready for an official compliance test in 2011.

\subsection{Background}

The consequence of our inability to manage and predict salmon populations is both ecologically and socially costly and has been thoroughly demonstrated over the past 20-30 years. Three factors help to explain the difficulty of understanding salmon passage and behavior. First, salmonids are exposed to a multi-dimensional complex of environmental conditions, which is difficult to replicate experimentally or to mathematically model (Underwood et al. 2000; Kerr 1990). Next, salmonids move across a heterogeneous environment, both natural and manmade, which requires addressing the questions of 
individual fitness, loss and gain, movements and behavior (Beitinger and Fitzpatrick 1979; Kramer et al. 1997; Hochachaka 1990). Lastly, biologists struggle to link individual fitness response to population level responses (Kerr 1990) resulting in a disjuncture between local and regional efforts and results. This specifically applies to the FCRPS. While outmigrating juvenile salmonids maneuver through the complicated FCRPS, their stress load and injuries, whether additive or synergistic, alter their fitness and subsequently their performance. ${ }^{1}$ While this knowledge seems common, no one to date has attempted to fully capture outmigrating juvenile salmonids' fitness data and apply them to population level fitness.

Over the past 25 years, much work has been done to increase passage survival rates for juvenile salmonids at the three lower main-stem dams. Progress at dams has entailed structural and operational improvements designed to benefit juvenile salmonid passage while minimizing impacts on power production as much as possible. For example, there has been extensive work on in-turbine screen systems and juvenile bypass system (JBS) facilities at McNary Dam (MCN), John Day Dam (JDA), and Bonneville Dam (BON). Also, numerous spill-level evaluations have been conducted at all three dams. At Bonneville Dam in 2009 a surface-flow outlet was refurbished at B2, a BGS was deployed in the B2 forebay, spillway flow deflectors were modified and have been studied, and the B1 sluiceway was reconfigured. Given these major improvements, the $2008 \mathrm{BiOp}$ called for performance standards and required the USACE to collect data on juvenile salmonid survival rates to compare to the BiOp standards starting in 2010.

While prescribed comparisons of dam survival with standards in the BiOp are very important, there are also ongoing needs to evaluate route-specific passage proportions and survivals, forebay resident times, tailrace egress times, and to occasionally test structures or operations to identify new ways of improving dam survival. Without route-specific information, it is difficult or impossible to determine why a dam failed to meet a standard or to identify ways to fix problems. Baseline biological data on fish distributions were summarized by Giorgi and Stevenson (1995) for JDA, The Dalles Dam (TDA), and BON; by Anglea et al. (2001) for JDA; by Johnson et al. (2007) and Ploskey et al. (2001) for TDA, and by Ploskey et al. (2007a) for BON. During the early 2000s, fish-passage proportions were most often estimated using fixed-aspect hydroacoustic or radio-telemetry methods, and survival estimates with active tags were based on detections of radio-tagged fish above and below the dams.

Before 2006, acoustic telemetry had only been used twice at Portland District projects, once at BON (Faber et al. 2001) and once at TDA (Cash et al. 2005). These studies focused on fish approach and passage. The Juvenile Salmon Acoustic Telemetry System (JSATS) was designed to meet the needs of passage and survival studies for juvenile salmonids in the Columbia River basin, and it avoids many of the limitations of other telemetry systems. In 2006, non-route-specific survival studies were conducted at JDA, TDA, and BON to assess the feasibility of using the JSATS for estimating dam-passage survival (Ploskey et al. 2007b). In 2007, a JSATS acoustic-telemetry survival study was conducted at the BON spillway (Ploskey et al. 2008), and in 2008, a JSATS route-specific survival study was conducted at JDA (Weiland et al. 2009), the BON spillway (Ploskey et al. 2009), and B2 (Faber et al. 2010). In 2009, JSATS route-specific studies were conducted at JDA (Weiland et al. 2011a) and B2 (Faber et al. 2011). The technology and tools for using JSATS are maturing thanks to significant advances with each year of

\footnotetext{
${ }^{1}$ Performance designates a volume of capacities where the volume is determined by the environmental conditions and interactions among the systems which contribute to those capabilities (Bennett 1989). Performance specifically refers to the application of various levels of biological organization from simple physiological functions to more complex organismal responses.
} 
study. The dam-face arrays deployed at JDA in 2008 detected over $99 \%$ of the tagged juvenile salmonids approaching the dam, and most approaching fish were successfully tracked. Over $98 \%$ were assigned a route of passage with high confidence. In 2009, the double array at JDA had a detection efficiency of 96.4\% for yearling Chinook salmon smolts, $95.6 \%$ for steelhead, and $97.9 \%$ for subyearling Chinook salmon smolts. High detection efficiencies also were observed in survival studies conducted in 2010 and spring 2011.

In 2009, PNNL conducted an acoustic-telemetry study at BON (Faber et al 2011). The study evaluated the effects of the BGS located in the forebay of the B2 and estimated passage and survival of yearling Chinook salmon (CH1), subyearling Chinook salmon (CH0), and juvenile steelhead (STH) passing downstream through this powerhouse, the dam as a whole, and through B1 and the spillway combined. The BGS was deployed to increase the survival of fish passing through B2 by increasing the percentage of outmigrating smolts entering the $\mathrm{B} 2 \mathrm{CC}$ - a surface-flow outlet known to be a relatively benign route for downstream passage at this dam. The BGS benefitted the collection efficiency and effectiveness for $\mathrm{CH} 1$ passing through the $\mathrm{B} 2 \mathrm{CC}$, but did not change $\mathrm{STH}$ or $\mathrm{CH} 0$ collection efficiency compared to prior study years. The B2CC passage efficiency for STH is very high with or without the BGS. Survival estimates for all smolts passing downstream through B2 were very high using triple-, paired-, and single-release Cormack-Jolly-Seber (Cormack 1965; Jolly 1965; Seber 1965) modeling methods and would meet current BiOp standards. Turbine unit 11 provides flow into the south of the B2 where the $\mathrm{B} 2 \mathrm{CC}$ is located; thus, the fact that this unit was off during summer may have reduced $\mathrm{B} 2 \mathrm{CC}$ efficiency for $\mathrm{CH} 0$. To satisfactorily test the effect the BGS has on improving the B2CC efficiency for $\mathrm{CH} 0$, turbine 11 should be operational throughout the testing period.

The 2008 BiOp on operation of the FCRPS contains a Reasonable and Prudent Alternative (RPA) that includes actions calling for measurements of juvenile salmonid survival (RPAs 52.1 and 58.1). These RPAs are being addressed as part of the federal research, monitoring, and evaluation (RME) effort for the FCRPS BiOp. Most importantly, the FCRPS BiOp includes performance standards for juvenile salmonid survival in the FCRPS against which the Action Agencies (Bonneville Power Administration, Bureau of Reclamation, and USACE) must compare compliance testing performance estimates, as follows (after the RME Strategy 2 of the RPA):

Juvenile Dam Passage Performance Standards - The Action Agencies' juvenile performance standards are an average across Snake River and lower Columbia River dams of $96 \%$ average dam passage survival for spring Chinook salmon and steelhead and 93\% average across all dams for Snake River subyearling Chinook. Dam passage survival is defined as survival from the upstream face of the dam to a standardized reference point in the tailrace.

The 2008 Columbia Basin Fish Accords Memorandum of Agreement [MOA] between the Three Treaty Tribes and FCRPS Action Agencies (3 Treaty Tribes and Action Agencies 2008), known informally as the Fish Accords, ${ }^{1}$ contains three additional requirements relevant to the 2010 survival studies (after the MOA Attachment A):

Dam Survival Performance Standard - Meet the 96\% dam passage survival standard for yearling Chinook salmon and steelhead and the 93\% standard for subyearling Chinook. Achievement of the standard is based on 2 years of empirical survival data....

\footnotetext{
${ }^{1}$ Available at http://www.salmonrecovery.gov/Files/BiologicalOpinions/MOA_ROD.pdf.
} 
Spill-Passage Efficiency and Delay Metrics - Spill-passage efficiency (SPE) and delay metrics under current spill conditions ... are not expected to be degraded ("no backsliding") with installation of new fish-passage facilities at the dams....

Future Research, Monitoring and Evaluation - The Action Agencies' dam survival studies for purposes of determining juvenile dam passage performance will also collect information about SPE, survival and delay between boat-restricted zones (BRZs), and other distribution and survival information. SPE and delay metrics will be considered in the performance check-ins or with Configuration and Operations Plan updates, but not as principal or priority metrics over dam survival performance standards. Once a dam meets the survival performance standard, SPE and delay metrics may be monitored coincidentally with dam survival testing.

This report summarizes the results of the 2010 spring acoustic-telemetry study of CH1 and STH at BON. This study is a precursor to a full-scale compliance study to be performed in 2011. Only singlerelease survival estimates were calculated for BON because there were no paired reference releases of fish downstream of BON in 2010. Therefore, BiOp performance standards were not explicitly tested. Surviving acoustically tagged juvenile STH and $\mathrm{CH} 1$ smolts released in the Columbia River upstream of JDA (near Arlington, Oregon), in TDA tailrace, and in the tailwater near Hood River, Oregon, were available to form virtual releases either at the BON forebay entrance array or at the face of the dam. Single-release passage survival estimates were made for fish passing through two river reaches: 1) the dam and $81 \mathrm{~km}$ of tailwater and 2) the forebay, dam, and $81 \mathrm{~km}$ of tailwater. A total of $3880 \mathrm{CH} 1 \mathrm{smolts}$ and 3885 juvenile STH were tagged and released to support survival studies at JDA, TDA, and BON in spring 2010. The JSATS tag model number ATS-156dB, weighing $0.438 \mathrm{~g}$ in air, was used in this investigation.

\subsection{Study Overview}

The purpose of spring 2010 monitoring at BON was to estimate single-release survival rates for $\mathrm{CH} 1$ and STH smolts, evaluate B2 BGS performance, and evaluate fish-passage metrics specified by the 2008 Fish Accords by taking advantage of fish released for the BiOp performance testing at TDA. For each fish stock, the following metrics were estimated using the JSATS technology:

- In this report, dam-passage survival is defined as survival from the upstream face of the dam to the first survival array located $81 \mathrm{~km}$ downstream of BON. The survival estimate includes the mortality of fish in this $81-\mathrm{km}$ river reach in addition to mortalities associated with dam passage. A singlerelease point estimate $>96 \%$ also would exceed the BiOp standard for a paired-release estimate, because the single-release estimate is more conservative than the paired-release estimate.

- In this report, we present two estimates of fish-passage efficiency (FPE): 1) SPE, which is defined as the number of fish passing through the spillway divided by the number passing the dam, and 2) spill + B2CC passage efficiency, as specified in the 2008 Fish Accords.

- Forebay residence time, defined by the median, mean, and standard error of the mean times that smolts take to travel the last 100-m upstream of the dam before passing into the dam (i.e., from the 100 -m mark to the dam face).

- Tailrace egress time, defined as the median, mean, and standard error of the mean times that smolts take to travel through the dam to the downstream tailrace boundary. 
- Project passage time, defined as the median, mean, and standard error of the mean times that smolts take to travel from the forebay entrance array through the dam to the tailrace egress array.

- Survival from the forebay entrance array to the primary array $81 \mathrm{~km}$ downstream of the dam was estimated instead of forebay-to-tailrace survival, which was specified as BRZ-to-BRZ survival in the Fish Accords. Forebay-to-tailrace survival estimates require tailrace and tailwater references releases that were not part of the 2010 study. We did provide a single-release estimate of survival from the forebay entrance array to the dam face.

The purpose of 2010 monitoring at BON was to estimate performance measures outlined in the 2008 FCRPS BiOp and the Fish Accords for CH1 and juvenile STH in spring and for subyearling Chinooks salmon in summer using a single-release passage and survival model, evaluate B2 BGS performance, and evaluate the effects of two spill treatments in summer.

The study methods and results described in the ensuing sections of this report are reported by run of fish and performance measure.

\subsection{Study Area}

The BON project area and modeled river discharge relative to historical estimates are described below.

\subsubsection{Bonneville Lock and Dam}

Bonneville Lock and Dam consists of several dam structures that together span the Columbia River between Oregon and Washington at rkm 235.1, about $65 \mathrm{~km}$ east of Portland, Oregon. From the Oregon shore north toward Washington, the current project is composed of a navigation lock, the 10-turbineunit B1, Bradford Island, an 18-gate spillway, Cascades Island, and the 8-turbine-unit B (Figure 1.1).

Primary fish passage routes include the spillway and two powerhouses; however, within each powerhouse, passage can be through surface-flow outlets, turbines, or the JBS. Smolts enter the JBS after encountering screens in the upper part of the turbine intakes. Screens divert fish to gatewell slots where they pass through orifices opening into a bypass channel, which carries them to an outfall downstream of the dam. The JBS at B1 was removed in 2004 because other routes were safer for fish. In 2003, the icetrash sluiceway channel at B2 was modified and lengthened so that water was discharged downstream from the tip of Cascades Island in 2004 and thereafter. The modified B2 sluiceway has since been referred to as the $\mathrm{B} 2 \mathrm{CC}$. All modifications were specifically designed to maximize non-turbine passage and survival of juvenile salmonids. In 2008 and 2009, a BGS was installed in the B2 forebay to guide fish toward the B2CC (Figure 1.2), and this device was still installed for testing in 2010. 


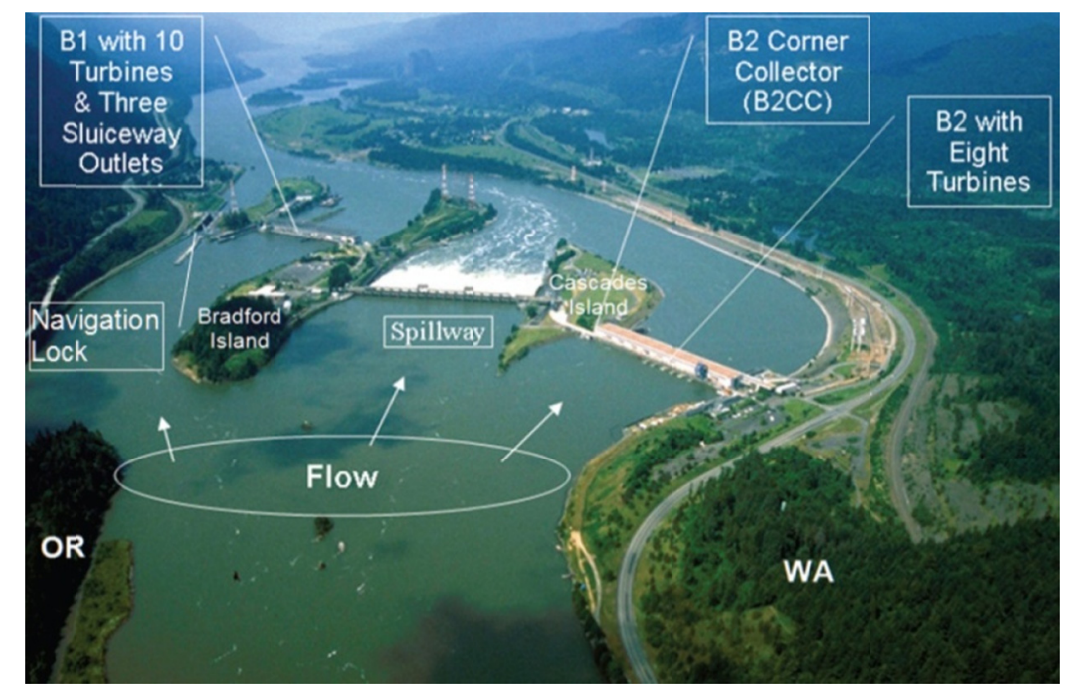

Figure 1.1. Plan View of the Bonneville Dam Project. The B1 sluiceway outlets and the B2 Corner Collector are surface overflow passage routes.
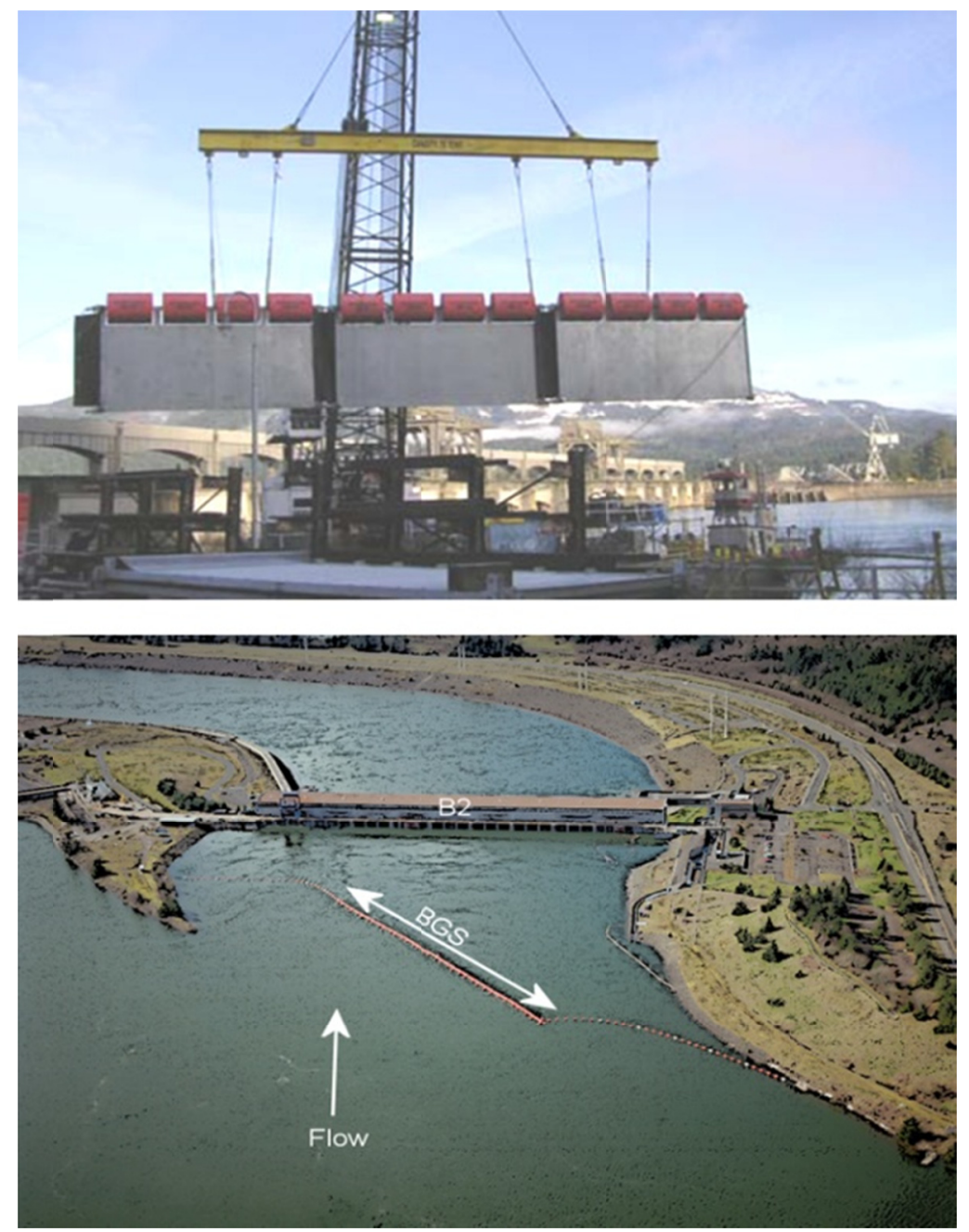

Figure 1.2. The Behavioral Guidance Structure with One Section Shown out of the Water (top); and as Deployed in the Forebay of the Bonneville Dam Second Powerhouse (B2; bottom) 
Fish with implanted passive integrated transponder (PIT) and acoustic tags were released at three locations upstream of BON and were detected on arrays of underwater hydrophones deployed at six river cross sections from rkm 236 to 86 (Figure 1.3). An array is a group of underwater receivers (nodes) deployed across an entire cross section of the river to listen for acoustic tags. Receivers located on the dam were cabled together and time synchronized by a global positioning system (GPS) clock, and receivers away from the dam were battery power devices called autonomous nodes. The distance between the uppermost release site near Roosevelt, Washington, and the last survival array at Oak Point, Washington, was $304 \mathrm{rkm}$. Excluding distances traveled by fish released at sites upstream of BON, the study area covered about $150 \mathrm{~km}$ of the lower Columbia River from BON to Oak Point, Washington, at rkm 86 (Figure 1.3). Cabled underwater hydrophones were deployed at two depths (shallow and deep) on every major pier at B1, B2, and the spillway to detect the passage of tagged fish and to assign passage routes based on a combination of three-dimensional (3D) tracking, two-dimensional (2D) tracking, and the location of last detection. Detection data from the primary array at CR153 and two downstream arrays deployed by a post-FCRPS (Estuary) survival study were used to enumerate capture histories and estimate the survival of smolts passing through BON.

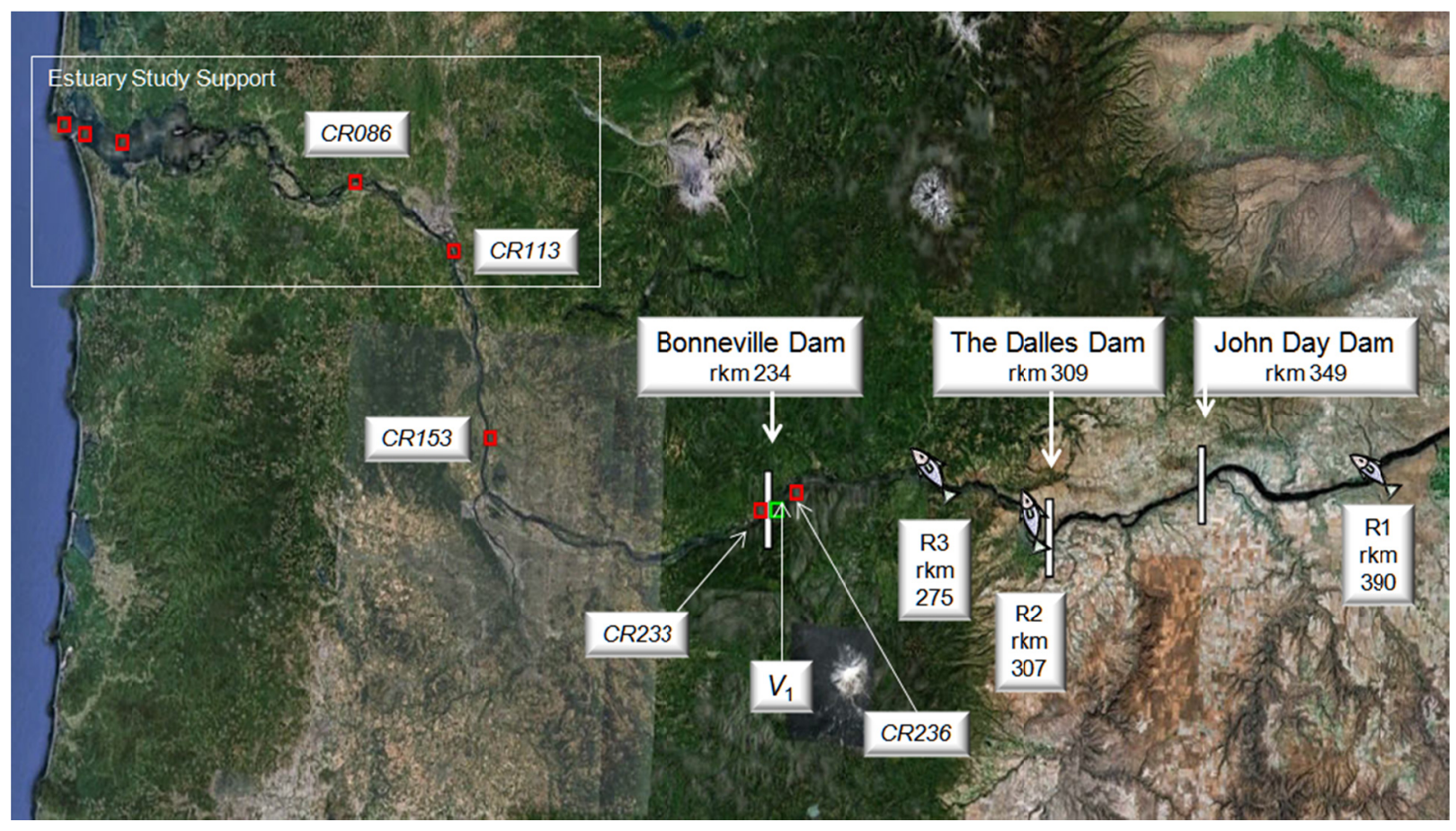

Figure 1.3. Bonneville Dam (BON) Study Area. Fish were released at three sites (R1, R2, and R3) upstream of Bonneville Dam and those detected at the face of BON were grouped to form a virtual release $\left(\mathrm{V}_{1}\right)$. Arrays of acoustic receivers were deployed in the BON forebay, tailrace, and at least six survival detection sites downstream, although only detections on arrays CR153, CR113, and CR086 were used to estimate survival in this report. (The background image was derived from Google Maps.)

\subsubsection{Modeled River Discharge Relative to Historical Estimates}

Modeled river discharge for water year 2009-2010 was between the 5th and 95th percentile of modeled discharge between 1929 and 1999 (Figure 1.4). 


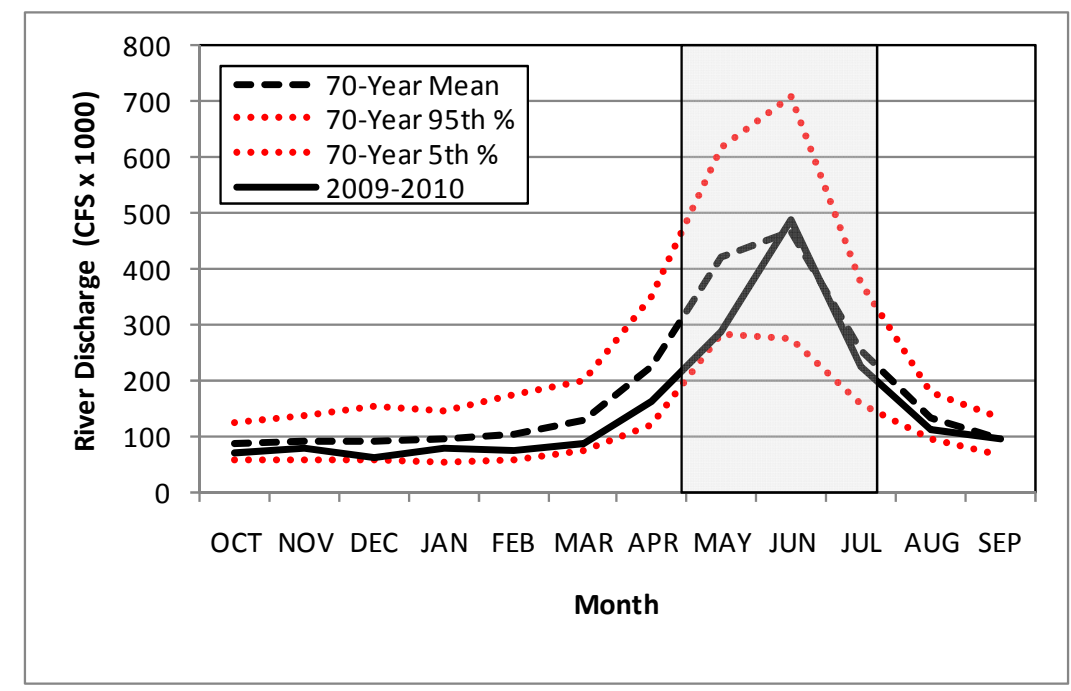

Figure 1.4. Plot of Modeled Columbia River Discharge in the 2009-2010 Water Year and Modeled 70-Year (1929-1999) Discharge. The mean and 5th and 95th percentiles are presented. Historical modeled estimates are from 2000 Level Modified Flow Report, and modeled estimates water year 2009-2010 were from River Forecast Center Runoff Model.

\subsection{Definitions}

For this report, we define virtual single-release survival, travel time, and passage efficiency metrics (Table 1.1). The survival metrics differ from those in the virtual paired-reference release design of Skalski (2009).

Table 1.1. Definitions of Performance Measures in This Study

\begin{tabular}{ll}
\hline \multicolumn{1}{c}{ Measure } & \multicolumn{1}{c}{ Definition } \\
\hline $\begin{array}{l}\text { Dam-passage } \\
\text { survival }\end{array}$ & $\begin{array}{l}\text { Survival from the upstream face of the dam to the primary survival detection array located } 81 \mathrm{~km} \\
\text { downstream from the dam. }\end{array}$ \\
$\begin{array}{l}\text { Forebay to } \\
\text { primary array } \\
\text { survival }\end{array}$ & $\begin{array}{l}\text { Survival from a forebay array 2 km upstream of the dam to the primary survival detection array } \\
\text { located } 81 \mathrm{~km} \text { downstream from the dam. }\end{array}$ \\
$\begin{array}{l}\text { Paired-release } \\
\text { survival }\end{array}$ & $\begin{array}{l}\text { Virtual single-release survival estimates for the dam and non-B2CC routes were divided by the } \\
\text { virtual single-release estimate for fish passing through the B2CC to provide a surrogate paired- } \\
\text { release estimate of survival. The B2CC typically has a virtual single-release survival rates that are }\end{array}$ \\
& $\begin{array}{l}\text { as high as or higher than those of tailrace reference releases of fish, which were not part of this } \\
\text { study. Therefore, paired-release estimates reported here should be conservative relative paired- } \\
\text { release estimates based on actual tailrace reference releases of fish. }\end{array}$ \\
$\begin{array}{l}\text { Forebay } \\
\text { residence time }\end{array}$ & $\begin{array}{l}\text { Median and average times required for smolts to travel from the time of first detection on the } \\
\text { forebay entrance array until the time of last detection on the dam-face array }\end{array}$ \\
$\begin{array}{l}\text { 100-m forebay } \\
\text { residence time }\end{array}$ & $\begin{array}{l}\text { Median and average times required for smolts to travel the last 100 } \mathrm{m} \text { of forebay until they pass } \\
\text { through the dam }\end{array}$ \\
$\begin{array}{l}\text { Tailrace } \\
\text { egress time }\end{array}$ & $\begin{array}{l}\text { Median and average time required for smolts to pass through the tailrace after they pass through } \\
\text { the dam, i.e., from time of last detection on the dam-face array until the time of last detection on } \\
\text { the tailrace egress array }\end{array}$
\end{tabular}


Table 1.1. (contd)

\begin{tabular}{ll}
\hline \multicolumn{1}{c}{ Measure } & \multicolumn{1}{c}{ Definition } \\
\hline $\begin{array}{l}\text { Spill-passage } \\
\text { efficiency }\end{array}$ & $\begin{array}{l}\text { Proportion of fish passing through the dam via the spillway, }{ }^{(\mathrm{a})} \text { and the proportion of fish passing } \\
\text { through the spillway and } \mathrm{B} 2 \mathrm{CC}^{(\mathrm{b})}\end{array}$ \\
$\begin{array}{l}\text { Project-passage } \\
\text { time }\end{array}$ & $\begin{array}{l}\text { Median and average time smolts take to travel from first detection on the array } 2 \mathrm{~km} \text { upstream of } \\
\text { the dam until the last detection on the tailrace exit array } 2-k m \text { downstream of the dam }\end{array}$ \\
Fish-passage & Proportion of fish passing through the dam via the spillway, sluiceway, and JBS. ${ }^{(\mathrm{c})}$ \\
efficiency & \\
\hline $\begin{array}{l}\text { (a) The historical definition. } \\
\text { (b) 2008 Fish Accord definition of spill-passage efficiency. } \\
\text { (c) By non-turbine routes. }\end{array}$
\end{tabular}

\subsection{Report Contents and Organization}

The ensuing chapters of this report present the study methods (Chapter 2.0), followed by results for survival, travel time, passage efficiency, and passage distribution information for CH1 (Chapter 3.0), STH (Chapter 4.0), and CH0 (Chapter 5.0). Discussion (Chapter 6.0) and references (Chapter 7.0) close out the main body of the report. In the appendices, we provide the fish tagging and release data (Appendix A), hydrophone locations (Appendix B), capture histories (Appendix C), detection and survival estimates (Appendix D), and an assessment of the assumptions for the survival estimates (Appendix E). 


\subsection{Methods}

Study methods cover environmental conditions, the release-recapture design and hydrophone deployment; tag life; fish handling, tagging, and release procedures; acoustic signal processing; and statistical methods. The primary research tool was the JSATS (McMichael et al. 2010).

\subsection{Environmental Collections}

Water discharge data by spill bay and turbine unit and elevation data for the forebay and tailrace are acquired by the USACE in 5-minute increments by the automated data-acquisition system at BON. Operators at the dam provided the data weekly. The 5-minute discharge data for the entire dam and spillway were averaged by day and plotted together with daily averages for the previous 10 -year period to provide some historical perspective for 2010 observations. Average water discharge and forebay water temperature data from 1999 through 2009 were downloaded from the UW Data Access in Real Time website (DART; http://www.cbr.washington.edu/dart).

Spill treatments in summer were broken into eight consecutive 2-day blocks. Each block consisted of 1 day of randomly selected spill treatment followed by another day with the alternative treatment. Spill treatments consisted of either $24 \mathrm{~h}$ of $95-\mathrm{kcfs}$ spill or $85-\mathrm{kcfs}$ day and 120-kcfs night spill. Treatments began after river discharge lowered to levels deemed manageable by the dam operators.

\subsection{Release-Recapture Design and Sample Sizes}

The release-recapture design used to estimate dam-passage survival at BON consisted of a combination of a virtual release $\left(\mathrm{V}_{1}\right)$ of fish at the forebay entrance array or at the face of the dam and the detection of the same fish below the dam (Figure 2.1). Releases of tagged fish near Roosevelt, Washington, TDA tailrace, and Hood River, Oregon, supplied a source of fish known to have arrived alive at the forebay entrance array or at the face of BON. By releasing the fish far enough upstream, they should have arrived at the dam in a spatial pattern typical of run-of-river (ROR) fish. This virtual-release group was then used to estimate survival of fish passing through the forebay, dam, and to $81 \mathrm{~km}$ downstream of the dam or the dam and $81 \mathrm{~km}$ of tailwater (Figure 2.1). We were unable to account and adjust for this extra mortality in the tailwater because there were no paired releases of fish below BON. The sizes of the releases of the acoustic- and PIT-tagged fish used in the dam-passage survival estimates are summarized in Table 2.1. 


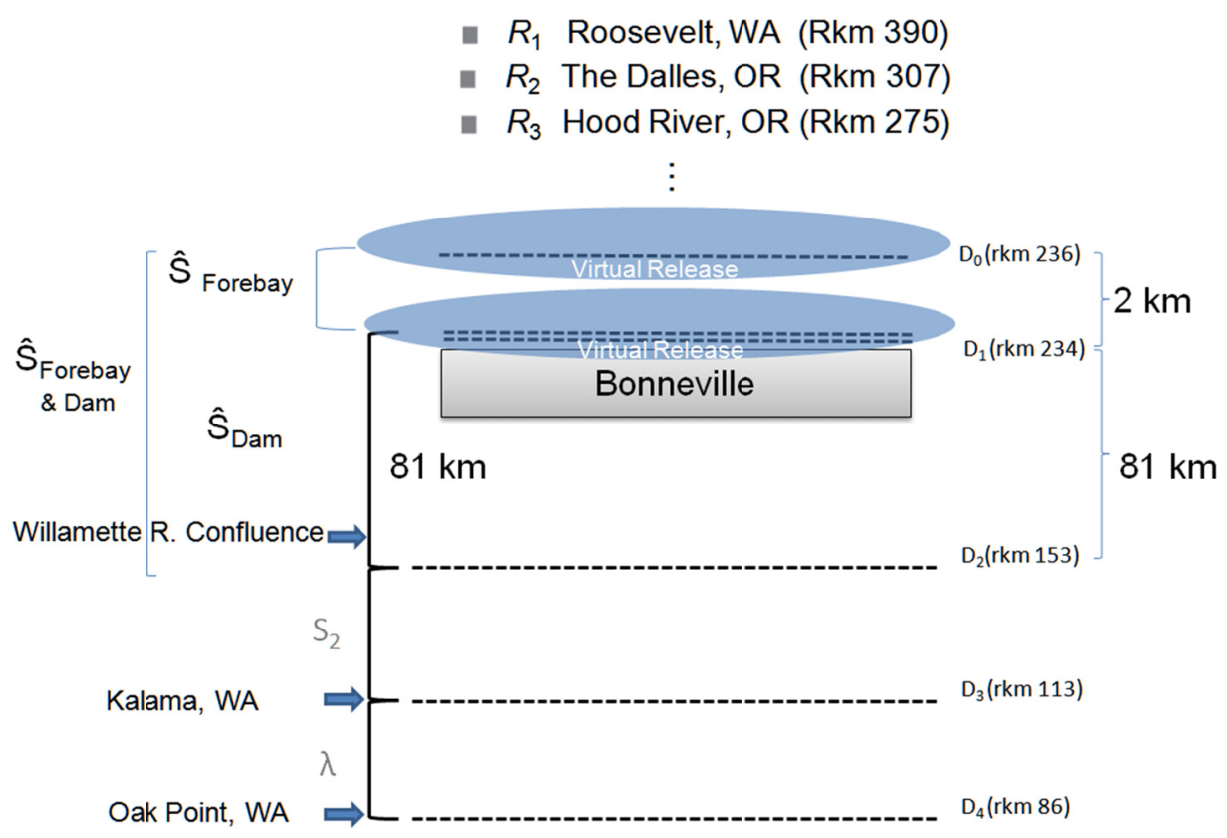

Figure 2.1. Schematic of the 2010 Study Design. The diagram shows the three releases of fish that could be regrouped to form virtual releases at the forebay entrance array $\left(D_{0}\right)$ or dam-face array $\left(D_{1}\right)$ and subsequent detections or non-detections on three downstream arrays $\left(D_{2}, D_{3}\right.$, and $\mathrm{D}_{4}$ ) that were used to create capture histories for estimating single-release survival rates down to the primary array $\left(\mathrm{D}_{2}\right)$.

Table 2.1. Sample Sizes of Acoustic-Tag Releases Used in the 2010 Survival Study at Bonneville Dam

\begin{tabular}{|c|c|c|c|c|c|}
\hline \multirow[b]{2}{*}{ Release Location } & \multirow[b]{2}{*}{$\begin{array}{l}\text { Yearling } \\
\text { Chinook }\end{array}$} & \multirow[b]{2}{*}{$\begin{array}{l}\text { Juvenile } \\
\text { Steelhead }\end{array}$} & \multicolumn{3}{|c|}{ Subyearling Chinook Salmon } \\
\hline & & & $\begin{array}{c}\text { Pooled } \\
\text { Treatments }\end{array}$ & $\begin{array}{c}\text { 85-kcfs Day } \\
\text { 120-kcfs } \\
\text { Night Spill }\end{array}$ & $\begin{array}{c}\text { 24-h, } \\
\text { 95-kcfs Spill }\end{array}$ \\
\hline Above John Day near Arlington, Oregon $\left(R_{1}\right)$ & 2287 & 2288 & 2849 & & \\
\hline The Dalles Dam Tailrace $\left(R_{2}\right)$ & 796 & 799 & 800 & & \\
\hline Bonneville Reservoir $\left(R_{3}\right)$ & 797 & 798 & 800 & & \\
\hline Total Tagged and Released $\left(R_{1}, R_{2}\right.$, and $\left.R_{3}\right)$ & 3880 & 3885 & 4449 & & \\
\hline \multicolumn{6}{|l|}{ Virtual Release Numbers $\left(\mathrm{V}_{1}\right)$} \\
\hline Dam and $81 \mathrm{~km}$ of tailwater passage & 3358 & 3373 & $1443^{(a)}$ & $725^{(\mathrm{b})}$ & $896^{(\mathrm{b})}$ \\
\hline $\begin{array}{l}\text { (a) Based on TDA tailrace and Hood Ri } \\
\text { (b) Based on all upstream releases (Roo }\end{array}$ & nly. & & d) & . & atment \\
\hline
\end{tabular}

\subsubsection{Federal and State Permitting}

Records were kept on all smolts handled and collected (both target and non-target species) for permit accounting. Collections were conducted in conjunction with routine sampling at the Smolt Monitoring Facility (SMF) at JDA to minimize handling impacts. Surgical candidates collected from routine SMF target sample sizes were accounted for under permits issued to the SMF. Additional fish needed to meet 
research needs (beyond SMF goals) were accounted for under separate federal and state permits. A federal scientific take permit was authorized for this study by the National Oceanic and Atmospheric Administration (NOAA) Fisheries Hydropower Division's FCRPS Branch and administered by NOAA (permit number 13-09PNNL40). The Oregon Department of Fish and Wildlife authorized take for this study under permit number P14273. The federal and Oregon permits were both authorized under the 2004 FCRPS BiOp. All requirements and guidelines of both permits were met and reports of collection and release were reported to both agencies.

\subsubsection{Acoustic and PIT Tags}

The acoustic tags used in the 2010 study (Figure 2.2) were manufactured by Advanced Telemetry Systems, Inc. ${ }^{\circledR}$ (ATS). Each tag, model number ATS-156dB, measured $12.02 \mathrm{~mm}$ in length, $5.21 \mathrm{~mm}$ in width, $3.72 \mathrm{~mm}$ in thickness, and weighed $0.430 \mathrm{~g}$ in air ( $0.29 \mathrm{~g}$ in water). The tags had a nominal transmission rate of 1 pulse every 3 seconds. Nominal tag life was expected to be about 25 days. Each tag was acoustically activated by Cascade Aquatics, Inc., using a Pinger dish designed by ATS to activate or deactivate tags. Each pulse from an activated JSATS tag contains a complex phase-encoded signal that uniquely identifies the transmitting tag without varying pulse duration.

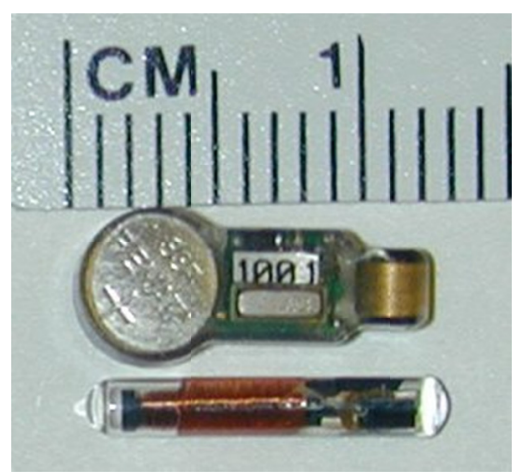

Figure 2.2. JSATS 0.43-g Acoustic Micro-Transmitter and PIT Tag Surgically Implanted in Yearling and Subyearling Chinook Salmon and Steelhead Smolts in 2010

\subsection{The Collection and Tagging Site}

Fish obtained from the JDA JBS were surgically implanted with JSATS tags, and then transported to three different release points, as described in the following sections. The SMF is situated on the south side of JDA at the downriver edge of the JBS where bypassed juvenile salmonids and other fishes are routed through a series of flumes and dewatering structures. Smolts can be diverted into the SMF as part of a sample of the JBS population for routine smolt monitoring (Martinson et al. 2006) or directed into the tailrace through an outfall pipe located downstream of the facility. Routinely sampled smolts also were rerouted to the tailrace outfall after they were examined unless they were selected for tagging as part of this study of survival rates.

\subsection{Fish Collection, Tagging, and Holding}

The collection, tagging, holding, and release of fish during this study are described in the following sections. 


\subsubsection{Collection}

Juvenile salmonids were diverted from the JBS and routed into a 1795-gal holding tank in the SMF. About 150-200 smolts and other fishes were crowded with a panel net into a 20- by 24-in. pre-anesthetic chamber. Water levels in the chamber were lowered to about 8 in. $(48 \mathrm{~L})$ at which point fish were anesthetized with $60 \mathrm{~mL}$ of a stock tricaine methanesulfonate (MS-222) solution prepared at a concentration of $50 \mathrm{~g} / \mathrm{L}$. Once they were anesthetized, fish were routed into the examination trough. Technicians added MS-222 as needed to maintain sedation, and 5 to $10 \mathrm{~mL}$ of PolyAquaTM was added to reduce fish stress. Water temperatures were monitored in the main holding tank and in the examination trough, and water in the trough was refreshed before temperatures there increased more than $2^{\circ} \mathrm{C}$ above those observed in the main holding tank.

Once they were in the examination trough, smolts targeted for surgical procedures were evaluated in accordance with the following specific acceptance and rejection criteria:

- Qualifying (Acceptable) Conditions

- $\quad$ size $>95 \mathrm{~mm}$

- visible elastomer tag(s) present or absent

- adipose-fin clipped or unclipped

- presence of trematodes, copepods, leeches

- short operculum

- healed (moderate) injuries (e.g., bird strikes)

$-\quad \leq 3 \%$ fungal patch

- minor fin blood

- partial descaling (3-19\%)

- STH with eroded pectoral or ventral fins (likely hatchery STH).

- Disqualifying Conditions

$-\quad \geq 20 \%$ descaling

- body punctures (showing blood, e.g., predator marks, bird strikes, head wounds, nose/snout injuries)

- obvious signs of bacterial kidney disease

- $\quad$ eye hemorrhage or pop eye

- $\quad>3 \%$ coverage with fungus

- deformed

- holdovers (fish not "spring” CH1 or "summer" CH0)

- PIT- or radio-tagged or other post-surgical fishes

- notable operculum damage (except short operculum)

- presence of columnaris, furuncles 
- injured caudal peduncles

- injured caudal fins

- fin hemorrhage.

Non-target species and fish that did not meet the above criteria were released to the river through the SMF holding system after a 30-minute recovery period. Accepted fish were counted and released into transfer buckets containing fresh river water before being moved to one of six 80 -gal pre-surgery holding tanks, where they were held for 18 to 30 hours before surgery. The pre-surgery holding duration depended on the time of collection and the time of tagging on the next day.

During spring and summer tagging seasons, 1,957 out of 12,214 fish were rejected for tagging (16\%). Fish that were rejected during the tagging process were placed in a recovery tank to allow for the anesthesia to be displaced from their system before releasing them. The total number of fish rejected and reason for their rejection are listed in Table 2.2.

Table 2.2. Number of Fish Rejected by Criteria During Spring and Summer Tagging at John Day Dam $(\mathrm{CH} 1=$ Yearling Chinook, $\mathrm{SH}=$ Steelhead, $\mathrm{CH0}=$ Subyearling Chinook $)$

\begin{tabular}{lccc}
\hline \multicolumn{1}{c}{ Rejection Criteria } & $\begin{array}{c}\text { Number } \\
\text { Rejected CH1 }\end{array}$ & $\begin{array}{c}\text { Number } \\
\text { Rejected SH }\end{array}$ & $\begin{array}{c}\text { Number } \\
\text { Rejected CH0 }\end{array}$ \\
\hline Descaling & 147 & 208 & 227 \\
Fungus & 48 & 60 & 9 \\
Bacterial kidney disease & 2 & 0 & 2 \\
Skeletal deformation & 8 & 6 & 10 \\
Parasites & 0 & 4 & 34 \\
Emaciation & 1 & 0 & 1 \\
Lacerations & 30 & 47 & 71 \\
Hemorrhage & 12 & 2 & 5 \\
Popeye & 12 & 6 & 5 \\
Fin rot & 5 & 1 & 5 \\
Head defect & 1 & 1 & 1 \\
Lesions & 14 & 21 & 23 \\
Moribund & 0 & 0 & 2 \\
Operculum damage & 16 & 42 & 25 \\
Size & 11 & 151 & 203 \\
PIT-tagged & 156 & 149 & 119 \\
Other & 16 & 33 & 5 \\
\hline
\end{tabular}

\subsubsection{Tagging}

The number of personnel on hand was the biggest contributor to ensuring that all tagged fish were handled as efficiently and un-intrusively as possible to minimize handling times. A team of eight or nine people conducted the tagging process. One individual was responsible for anesthetizing fish and delivering them to be weighed and measured; two people were responsible for weighing, measuring, and 
recording data; one person was responsible for taking lateral photographs with a high-resolution digital camera; three people performed surgeries to implant tags in the fish; and one or two people were responsible for moving tagged fish into the post-surgery tanks.

The team followed the latest guidelines for surgical implantation of acoustic transmitters in juvenile salmonids (USACE 2011). Procedure development is an ongoing process initiated by the USACE for contractors conducting survival studies. Numerous steps were taken to minimize the handling impacts of collection and surgical procedures. Most smolts used for tagging were part of the routine collection for SMF monitoring and additional fish did not have to be collected to meet the tagging quota on most days.

Fish were netted in small groups from the 80-gal holding tanks and placed in a 5-gal "knockdown" bucket with water and $20 \mathrm{~mL}$ of a $40-\mathrm{g} / \mathrm{L}$ stock solution of MS-222. Once a fish lost equilibrium, it was transferred to a processing table in a small container of river water. Species type, whether the adipose fin was intact or clipped, and fork length $( \pm 1 \mathrm{~mm})$ were recorded on a GTCO CalComp Drawing Board VI digitizer board. Fish were weighed $( \pm 0.01 \mathrm{~g})$ on an Ohaus Navigator scale and returned to the small transfer container along with an assigned PIT tag and an activated acoustic tag. Length, weight, species type, tag codes, and fin clip were all added automatically into the tagging database by PIT Tag Information System (PTAGIS) P3 software to minimize human error. The transfer container, fish, and tags were assigned a recovery bucket number and passed to the photo table. Photographs were taken of both sides of the fish while in the transfer container and then given to a surgeon for tag implantation.

An established protocol was used in the tagging process to help minimize the handling impact on tagged fish. All surgical instruments were sterilized daily in an autoclave and each surgeon used four complete sets of instruments during each day's tagging. When a set was not being used, it was placed in a $70 \%$ ethanol solution for approximately 10 minutes. The instruments were then transferred to a distilled water bath for 10 minutes, to remove residual ethanol and any remaining particles, before being used again. To reduce the disruption of the mucus membrane at the incision, Poly-Aqua was used to help replace the membrane that was removed from the fish's epidermal layers. Anesthesia buckets were kept within $\pm 1^{\circ} \mathrm{C}$ of river temperature. Anesthesia solutions were either replaced or cooled with ice when temperatures exceeded protocols.

During surgery (Figure 2.3), the fish to be tagged were anesthetized in an 18.9-L (5-gal) "knockdown" bucket with fresh river water and MS-222 (tricaine methanesulfonate; $80 \mathrm{mg} / \mathrm{L}$ ). Anesthesia buckets were refreshed repeatedly to maintain the temperature within $\pm 2{ }^{\circ} \mathrm{C}$ of current river temperatures. Each fish was weighed and measured before tagging. Then, each fish was placed ventral side up and a gravity-fed anesthesia supply line was placed into its mouth. The dilution of the "maintenance" anesthesia was $40 \mathrm{mg} / \mathrm{L}$. Using a \#15 surgical blade or a Micro-Sharp stab scalpel with a 5-mm blade (depending on the surgeon's preference), a 6- to 8-mm incision was made ventrally in the body cavity, $3 \mathrm{~mm}$ from and parallel to the mid-ventral line and equidistant from the pelvic girdle and pectoral fin. A PIT tag was inserted followed by an acoustic tag. Both tags were inserted toward the anterior end of the fish. Two interrupted sutures of 5-0 monofilament with an RB-1 needle were used to close the incision. After closing the incision, the fish were placed in a 5-gal aerated recovery bucket and closely monitored until fish had reestablished equilibrium. Each bucket held one to five fish depending on the size of the fish and the number to be released at each site. Water in the transport buckets also was within $\pm 1^{\circ} \mathrm{C}$ of river water temperature. Each transport bucket had many 3/8-inch-diameter holes drilled through the upper one third of its height and around its circumference to allow water to flow through each bucket when it was submerged in a large post-surgery holding tank that had fresh river water flowing 
through it (Figure 2.4). The large holding tanks were insulated to keep the water temperature within acceptable limits. Fish were held in these tanks for 18 to 30 hours before being transported for release into the river.

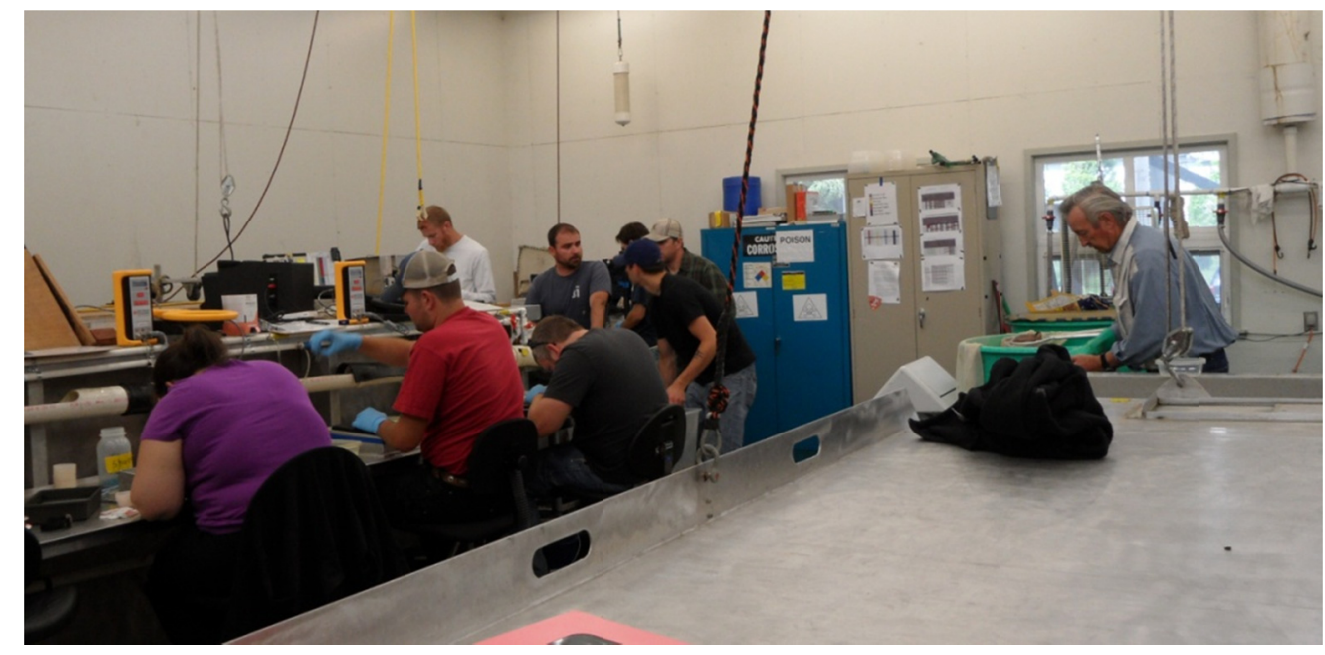

Figure 2.3. Surgical Implantation of Tags

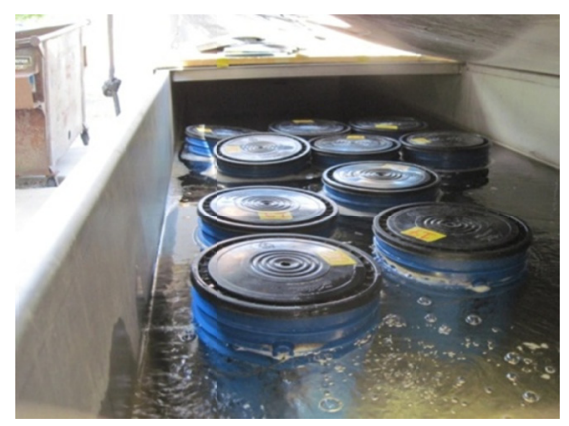

Figure 2.4. Post-Surgery Holding Tank with Recovery Buckets

\subsection{Transport and Release}

Tagged fish were transported from JDA by truck to the three release locations: Roosevelt, Washington, upstream of JDA near rkm 390; TDA tailrace near rkm 307; Hood River near rkm 275. To transport tagged fish, two 3/4-ton trucks were outfitted with two 180 -gal Bonar insulated totes. The totes could hold ten 5-gal fish buckets. The totes had snug-fitting lids and extra space to accommodate the addition of ice on hot days. A network of valves and plastic tubing was attached to an oxygen tank for delivering oxygen to the totes from a 2200-psi oxygen tank during transport. The Bonar totes were filled with fresh river water before fish buckets were removed from the post-surgery holding tanks and placed in the totes. Air lines were then placed into the totes. A YSI meter was used to measure the dissolved oxygen and the temperature of water in the totes before, during, and after transport to make sure that these properties stayed within acceptable limits. Transportation routes were adjusted to provide equal travel times to each release location from JDA.

Upon arriving at a release site, fish buckets were transferred to a boat for transport to the in-river release location. There were five release locations at each release cross section. Equal numbers of 
buckets of fish were released at each of the five locations for a given cross-section. During spring, releases occurred for 37 consecutive days (from April 28 to June 1, 2010). During summer, releases occurred for 35 consecutive days (from June 13 to July 17, 2010). Releases alternated between daytime and nighttime, every other day, over the course of the study. The timing of the releases at the three locations was staggered to help facilitate downstream mixing (Table 2.3).

Just before fish were released in the river, fish buckets were opened to check for dead fish. Every dead fish was returned to the tagging facility and scanned with a BioMark portable transceiver PIT-tag scanner to identify the implanted PIT-tag code. The associated acoustic-tag code was identified later from tagging data which recorded all pairs of PIT and acoustic tags implanted in fish the previous day. Dead tagged fish were released once a week to determine if they were detected on downstream survivaldetection arrays. Post-tagging, pre-release mortalities were low for each run of fish studied in 2010 $(\mathrm{YC}=0.1 \% ; \mathrm{STH}=0.05 \% ; \mathrm{SYC}=0.22 \%)$.

Table 2.3. Relative Release Times for the Acoustic-Tagged Fish to Accommodate Downstream Mixing. Releases were timed to accommodate the approximately 60-h travel time between $R_{1}$ and $R_{2}$ and the 13-h travel time between $R_{2}$ and $R_{3}$.

\begin{tabular}{ccc}
\hline & \multicolumn{2}{c}{ Relative Release Times } \\
\cline { 2 - 3 } Release Location & Daytime Start & Nighttime Start \\
\hline$R_{1}(\mathrm{rkm} 390)$ & Day 1: $0900 \mathrm{~h}$ & Day 2: $2000 \mathrm{~h}$ \\
$R_{2}(\mathrm{rkm} \mathrm{307)}$ & Day 3: $2000 \mathrm{~h}$ & Day 5: $0900 \mathrm{~h}$ \\
$R_{3}(\mathrm{rkm} 275)$ & Day 4: $0900 \mathrm{~h}$ & Day 5: 2200 h \\
\hline
\end{tabular}

\subsection{Detection of Tagged Fish}

Two types of JSATS arrays — cabled and autonomous - were deployed to detect fish implanted with JSATS acoustic transmitters and released at Roosevelt, Washington, as they passed downstream through the study reach between the BON forebay array, at rkm 236, and Oak Point, Washington, at rkm 86 (Table 2.1). An array is defined as a group of nodes deployed within $1 \mathrm{~km}$ of a specific river cross section to detect acoustically tagged fish. Nodes were deployed at distances $\leq 150 \mathrm{~m}$ from each other and $\leq 90 \mathrm{~m}$ from the shore. However, additional nodes sometimes had to be deployed in entrances to or exits from side channels formed by islands downstream of BON.

\subsubsection{Cabled Dam-Face Arrays}

The cabled dam-face receiver was designed by PNNL for the USACE Portland District using an offthe-shelf user-build system (Weiland et al. 2011b). Each cabled receiver consists of a computer, dataacquisition software, digital signal-processing cards with field-programmable logic gate array (DSP+FPGA), GPS card, a four-channel signal-conditioning receiver with gain control, hydrophones, and cables (Figure 2.5). The software that controls data acquisition and signal processing is the property of the USACE and is made available by the USACE as needed. 


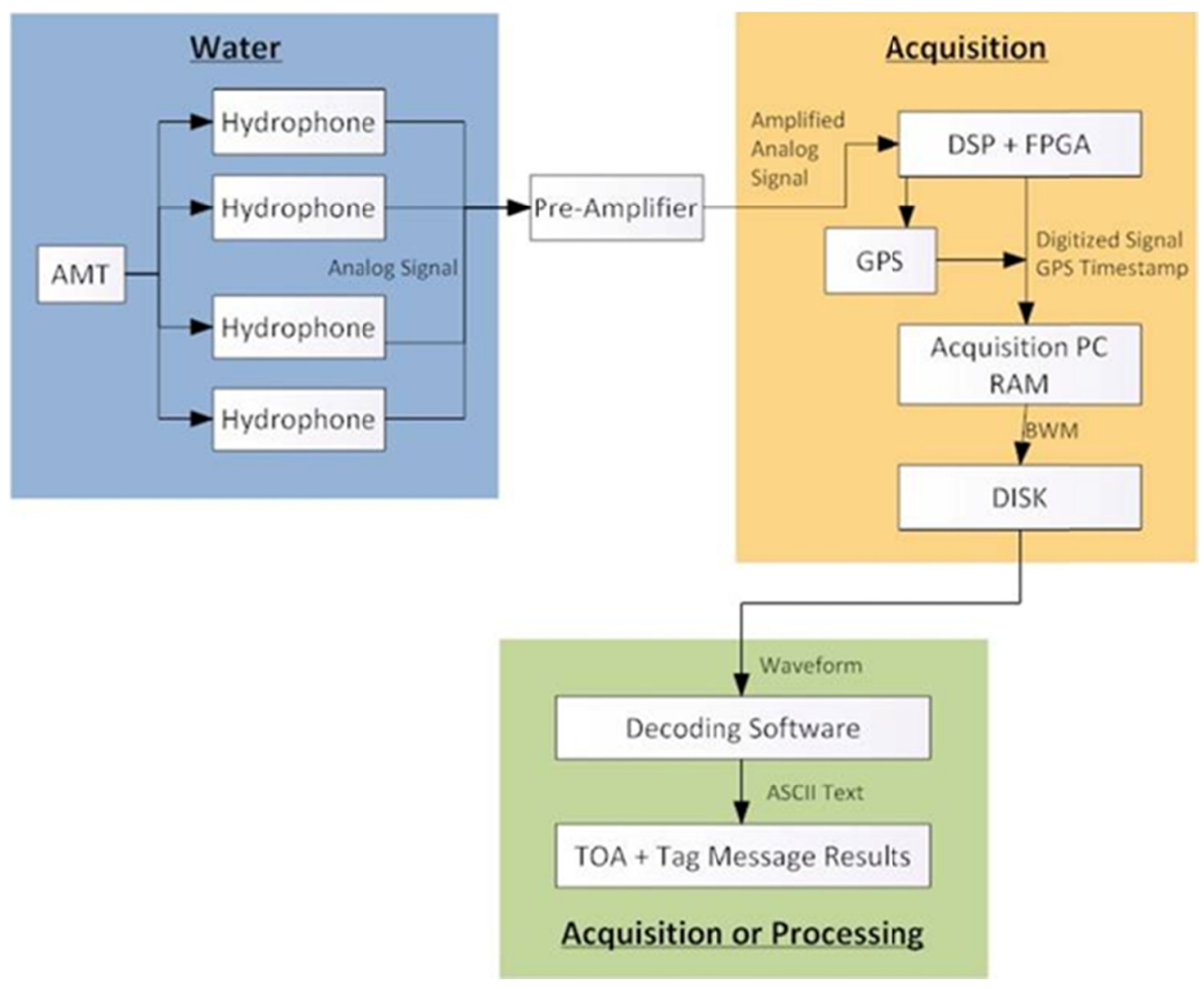

Figure 2.5. Schematic of Dam-Face Receiver System Showing the Main Components and Direction of Signal Acquisition and Processing. Abbreviations are as follows: AMT = acoustic microtransmitter implanted in fish; DSP = digital signal processing card; FPGA = field programmable logic gate array; GPS = global positioning system; $\mathrm{PC}=$ personal computer; $\mathrm{RAM}=$ random access memory; $\mathrm{BWM}=$ binary waveform; TOA $=$ time of arrival.

A modular JSATS cabled array was deployed along the upstream face of BON to detect JSATStagged smolts approaching the dam. Two hydrophones were deployed at different depths on each main pier and eight hydrophones were attached to clump mounts that were lowered to the bottom of the forebay about 33 m upstream of the dam face (Figure 2.7). Clump-mounted hydrophones were deployed to provide additional detections off of the plane of the dam face to increase the resolution of 3D tracking (Deng et al. 2011a).

The dam-face cabled array consisted of 84 cabled hydrophones mounted on piers or walls adjacent to piers and distributed among 22 four-channel receivers. Hydrophones were deployed on trolleys in pipes attached to the main piers at the powerhouse and spillway and on some adjacent concrete walls (Figure 2.6) in a known fixed geometry. The GPS coordinates and elevations of dam-face mounted cabled hydrophones are listed in Appendix B. Trolley pipes at the powerhouse were 4 in. in diameter, and made of powder-coated schedule 40 steel pipe that were slotted down one side for deployment of the trolley. Pipes at the powerhouses were $80 \mathrm{ft}$ long and extended from deck level at elevation $90 \mathrm{ft}$ above mean sea level (MSL) down to a mid-intake depth at elevation ranging from 12 to $15 \mathrm{ft}$ above MSL (Figure 2.7). A cone was attached to the top of the pipe to assist with trolley insertion. At the powerhouses (B1 and B2), hydrophones were deployed at two elevations, one shallow (between about 
63 and $70 \mathrm{ft}$ above MSL) and the other deep (between about 12 and $15 \mathrm{ft}$ above MSL). The precise elevation of each hydrophone was calculated by measuring cable and trolley lengths between shallow and deep hydrophones and the length of cable to the top of the pipe and the slope of the pier on which the slotted pipe was mounted. Reference beacons (Figure 2.8) transmitting at $156 \mathrm{~dB} \| 1 \mu \mathrm{Pa}$ at $1 \mathrm{~m}$ were attached to four or five hydrophone trolleys at each dam structure so that transmitted signals could be detected by every hydrophone on each dam face. Detection of beacon signals provided feedback on hydrophone performance throughout the season.

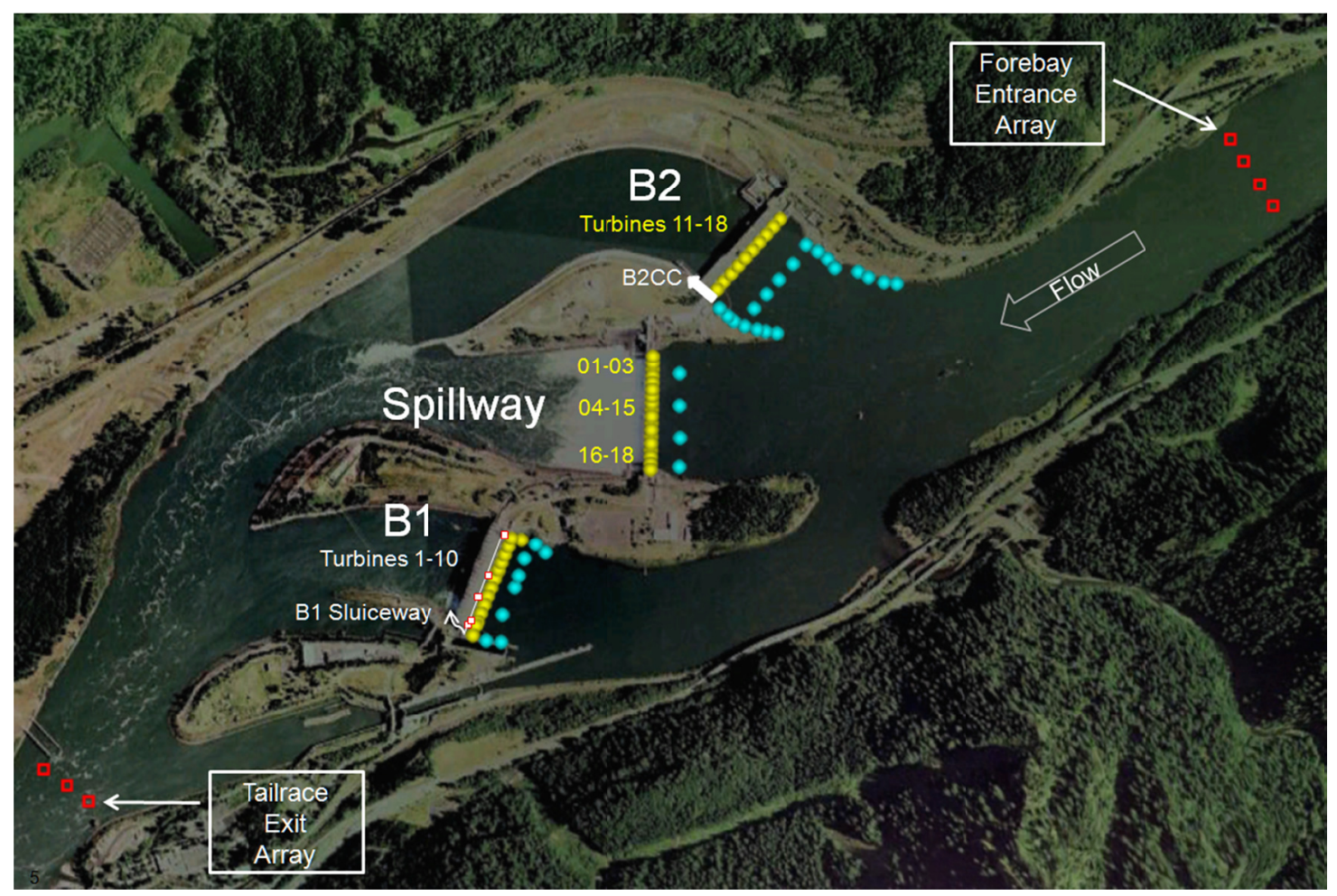

Figure 2.6. Location of Hydrophones on the Dam Face (yellow dots) and in the Immediate B1, B2, and Spillway Forebays (blue dots) of Bonneville Dam in 2010. Red squares indicate positions of autonomous node deployments in the forebay entrance array and tailrace exit array. The direction of surface-flow outlet flow is indicated by white arrows at each powerhouse.

Ten clump mounts were also deployed in the forebays about 75-100 m upstream of dam faces and away from shore. There were four at B2, four at the spillway, and two at B1. At B1, two hydrophones also were deployed on either side of the pier extending upstream from between turbines 6 and 7 . Each clump mount and B1 pier mount had a single hydrophone that was used to verify positioning of pier nose deployed hydrophones. There also were 15 near-shore hydrophones deployed on buoys in the B2 forebay. 


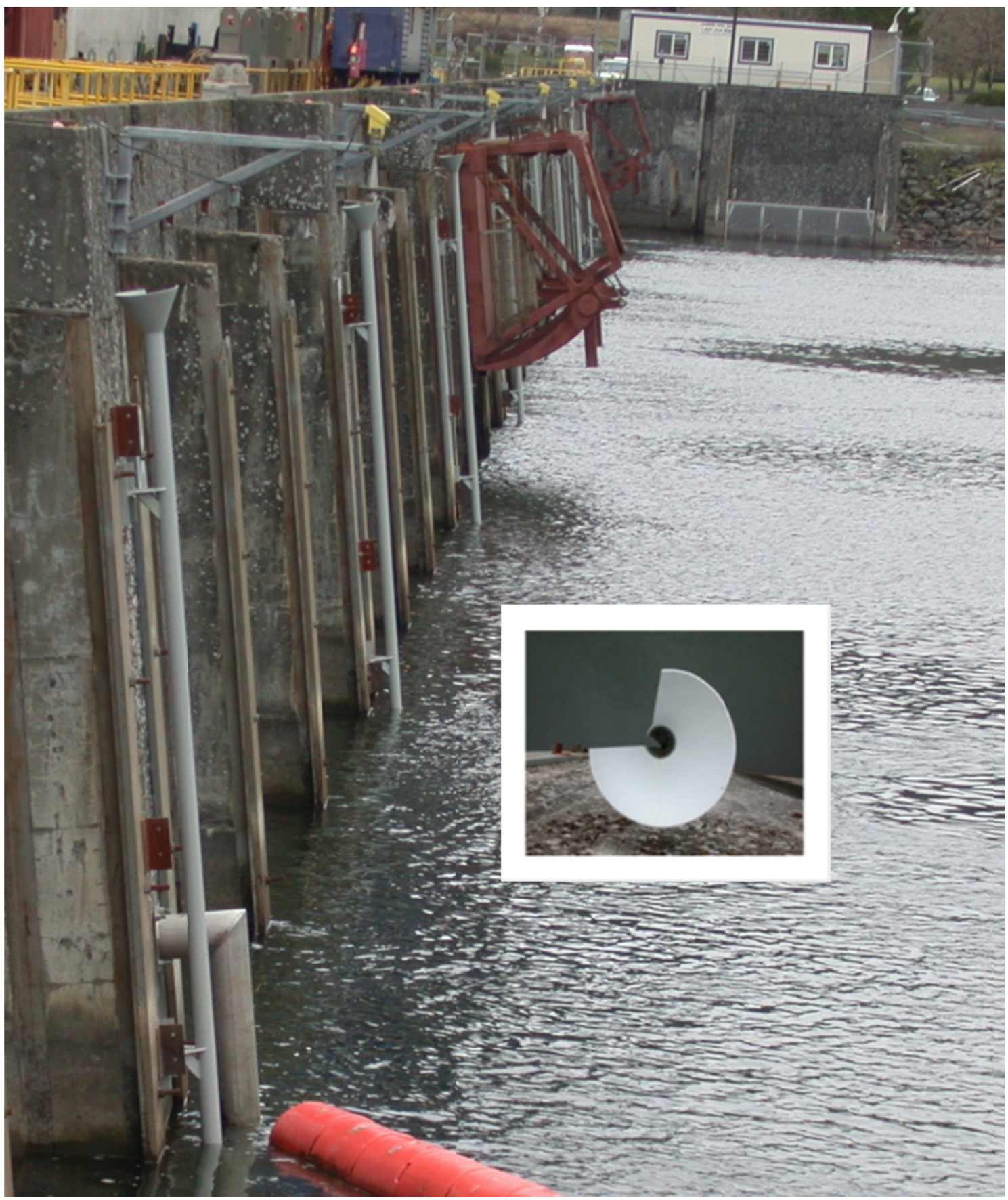

Figure 2.7. Four-Inch-Diameter Trolley Pipe Mounted on Piers at B2 (upper inset view of pipe top). Similar 4-in.-diameter pipes were installed at B1.

At the spillway, hydrophones were mounted on trolleys that were deployed in 8-in.-diameter vertical slotted pipes that extended from about $4 \mathrm{ft}$ above maximum pool to the elevation of the ogee (Figure 2.8). At each spillway pier, one hydrophone was deployed at a shallow elevation (65.87-68.05 ft above MSL) and the other at a deep elevation (38.12-40.39 ft above MSL). The exact elevation of each hydrophone to the nearest $0.01 \mathrm{ft}$ was determined by measuring cable and trolley lengths between hydrophones and the length of cable suspending the trolleys below the top of each pipe. 

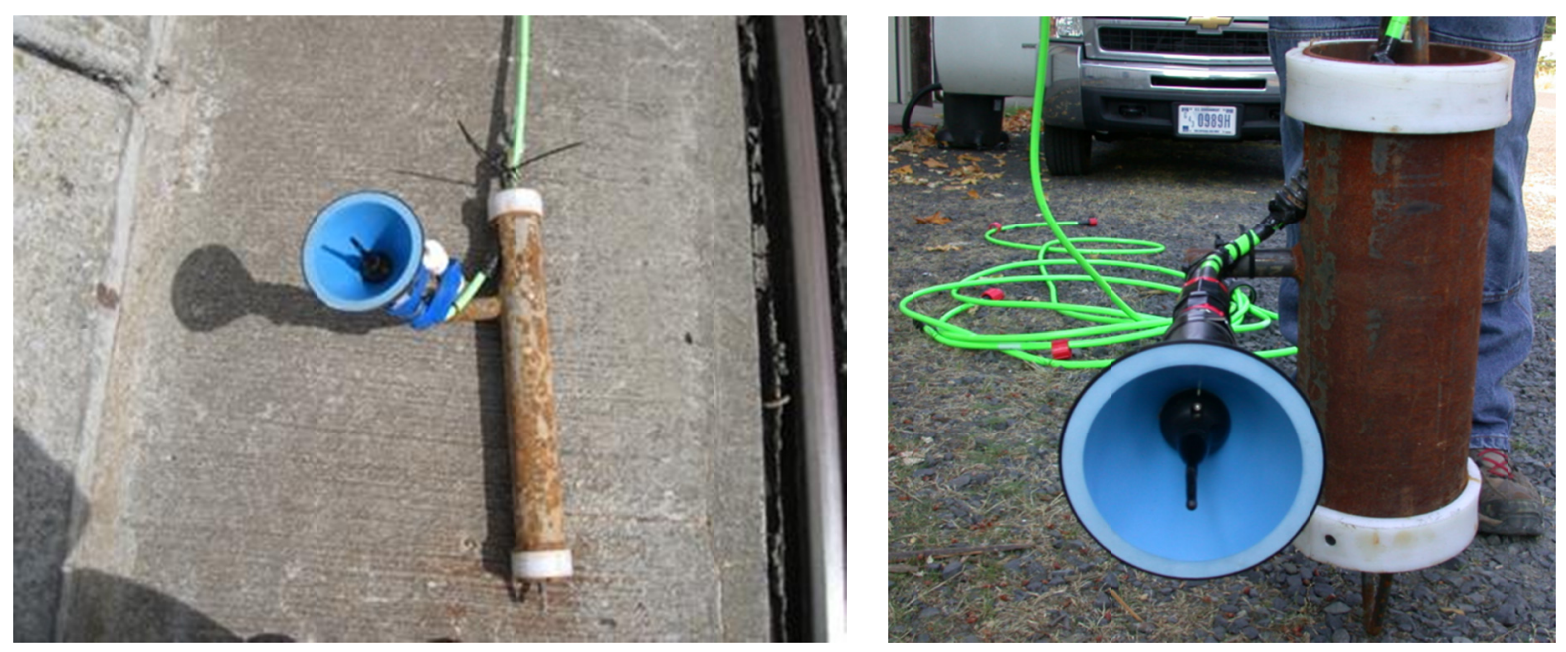

Figure 2.8. Trolleys Used to Deploy Hydrophones at B1 and B2 (left) and the Spillway (right). The photos show 4-in.- (left) and 8-in.- (right) diameter trolleys for slotted pipes. Each trolley had a steel arm to support a hydrophone that was surrounded by a plastic cone lined with anechoic material to prevent sound reception from a downstream direction. The white polyvinyl chloride object immediately to the right of the hydrophone baffle in the left picture is a reference beacon that was attached to four or five trolleys at each dam structure (B1, spillway, and B2).

The 3D double-detection array at the face of BON used to compose the virtual-release group was also used to identify the passage routes of fish through the dam. These passage-route data were used to calculate SPE and spill + B2CC passage efficiency. The 3D tracking data were further used to estimate forebay residence time within the 100-m zone nearest the dam. The fish used in the virtual release at the face of the dam were used to estimate tailrace egress time.

In addition to the detection arrays identified in Figure 2.9, hydrophone arrays were deployed below BON at rkm 49, 37, 22, 8, and 3. These arrays served as potential additional downstream detection arrays to improve precision in the survival analysis for BON.

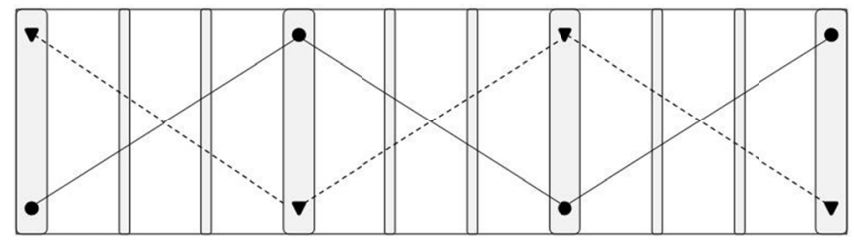

Figure 2.9. Front View Schematic of Hydrophone Deployments at Three Turbines Showing the DoubleDetection Arrays. The circles denote the hydrophones of Array 1 and the triangles denote the hydrophones of Array 2.

\subsubsection{Autonomous Node Arrays}

The Sonic Concepts autonomous acoustic-telemetry receiver (node) used in this study consisted of two coupled parts. The top was made from Schedule 40 10.16-cm-diameter polyvinyl chloride (PVC) pipe that was capped at the top and had a fitting with male threading at the bottom (see Figure 2.10). The 
cap was modified for watertight seating of a hydrophone, and the body below the cap housed the analog and digital boards for processing detected tag signals. A lubricated 10.16-cm-diameter rubber O-ring was fitted over the lower threaded end so that it would form a watertight seal when the node top was screwed together with the bottom. The node bottom was made from approximately $1 \mathrm{~m}$ of 10.16-cm-diameter PVC pipe and the upper end had a fitting with female threads for coupling it to the node top. The lower end of the node bottom was capped and a stainless-steel harness was located just below the upper fitting so the node could be attached to an anchor system, which is described later. An acoustic beacon that transmitted a signal four times louder than acoustic tags once every 15 seconds was attached to the outside of the battery housing just below the threaded end of the housing. This beacon was used to determine the location of a node if it didn't surface after it was acoustically released from an anchor. Beacons also could be used to determine when an adjacent node disappeared.

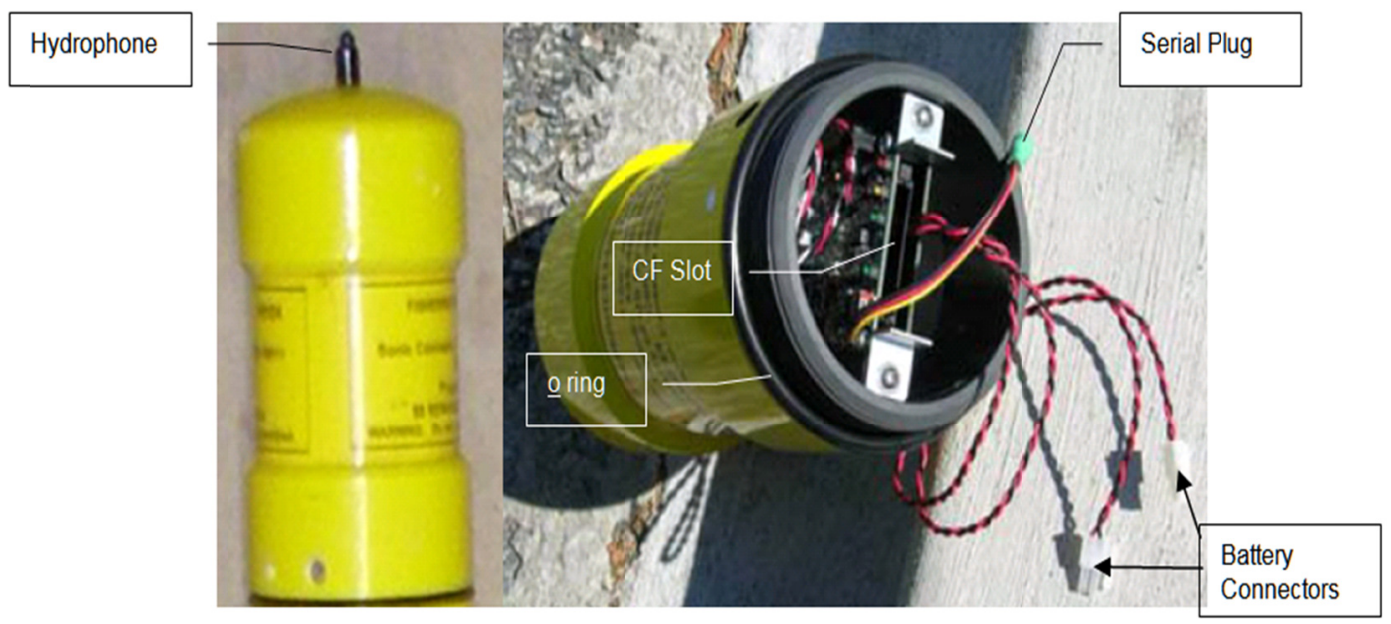

Figure 2.10. Side (left) and Bottom (right) View of a Node Top

Before deployment, 28-day lithium-ion batteries were gently lowered into the node bottom and secured in place with a battery-retention device. Wires from the batteries were attached to connectors from the analog board in the node top. One end of a serial cable was connected to a plug from the board set in the node top and the other end was plugged into a laptop computer so that staff could communicate with the node, set its date and time, and verify detection of a beacon tag. Next, a 1-gigabyte SanDisk Extreme III CompactFlash (CF) card was mounted in a slot on the board set, and the node top and bottom were screwed together until beveled edges of each piece compressed the O-ring to form a watertight seal. Just before putting the node into the water, we verified that a light-emitting diode on the node top housing was flashing, which indicated that the node was functioning properly and data would be written to the $\mathrm{CF}$ card. In the water, air space within the sealed node provided positive buoyancy, while the batteries in the node bottom provided ballast to help keep the node upright.

The length of autonomous node rigging varied with water depth at deployment sites. As shown in Figure 2.11, a 1.5-m section of line with three $2.72-\mathrm{kg}$ buoyancy floats was attached to a strap half way between the node tip and node bottom. An InterOcean Systems Model 11 acoustic release was attached to the other end of the $1.5 \mathrm{-m}$ line. The length of the $0.48-\mathrm{cm}$-diameter wire rope anchor line deployed varied with water depth, from 0.3 to $2 \mathrm{~m}$ long. One end of the anchor line was swagged to a 76.2-mm ring that fit into the mechanical latch end of the acoustic release and the other end was shackled to a 
34-kg anchor. In water $<5.5 \mathrm{~m}$ deep, we bound the node, float line, and acoustic release together with 1 -m-long zip-ties and used a short $(0.3-\mathrm{m})$ anchor line to keep the entire package under $1.5 \mathrm{~m}$ long.

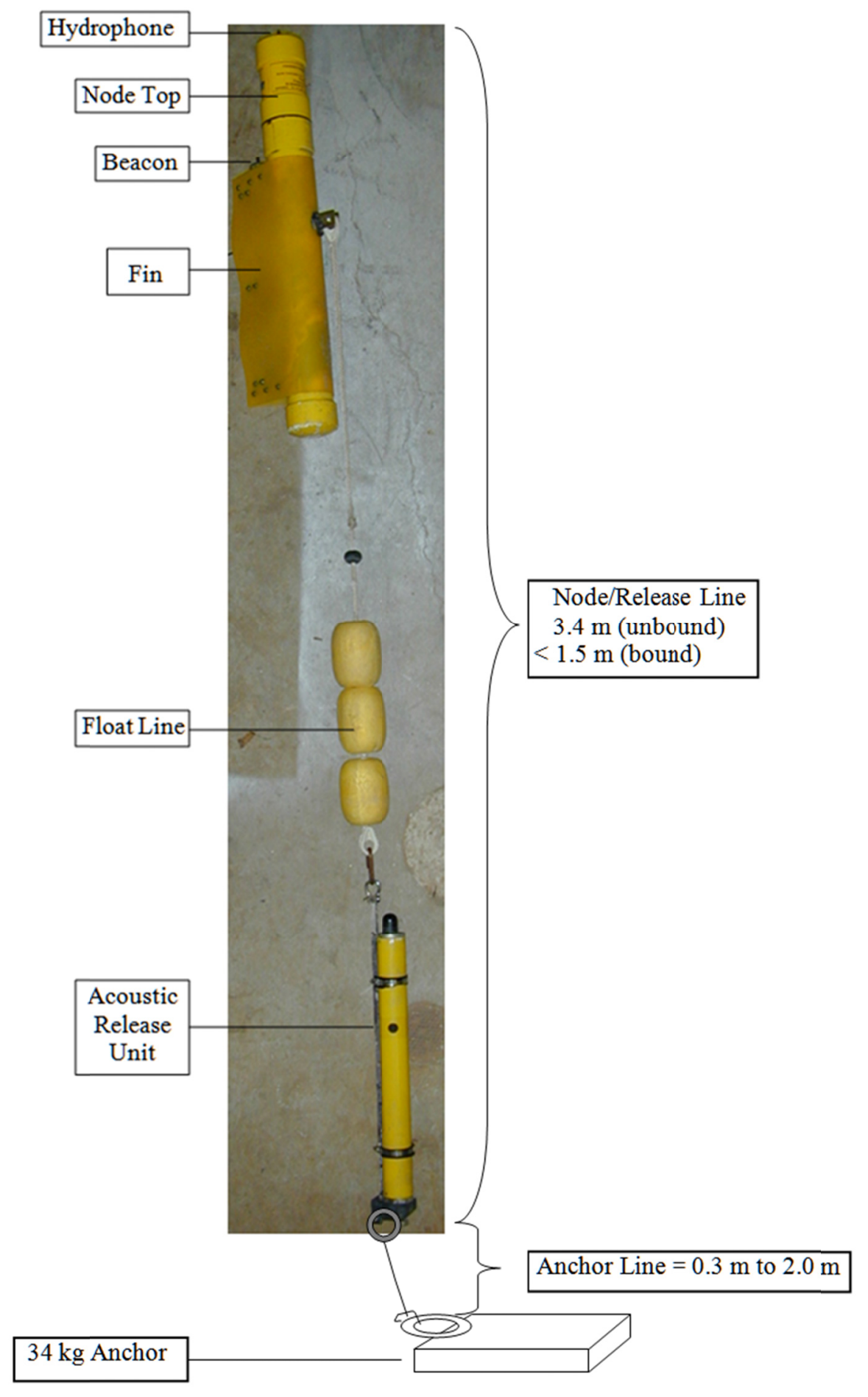

Figure 2.11. Autonomous Node Rigging 
Autonomous nodes were deployed in arrays across river cross sections to detect tagged fish migrating downstream through the study area. Autonomous node arrays for calculating project passage travel times in the BON forebay and tailrace near rkm 236.0 and 233.0, respectively (Figure 2.6; Figure 2.12a), and three arrays used for survival detection and calculations were deployed at rkm 153, 113, and 86.2 (Figure 2.12 panels b, c, and d). The GPS coordinates and depths of autonomous node deployments are listed in Appendix B.

(a) BON Forebay (upper right) \& Tailrace (lower left) Arrays

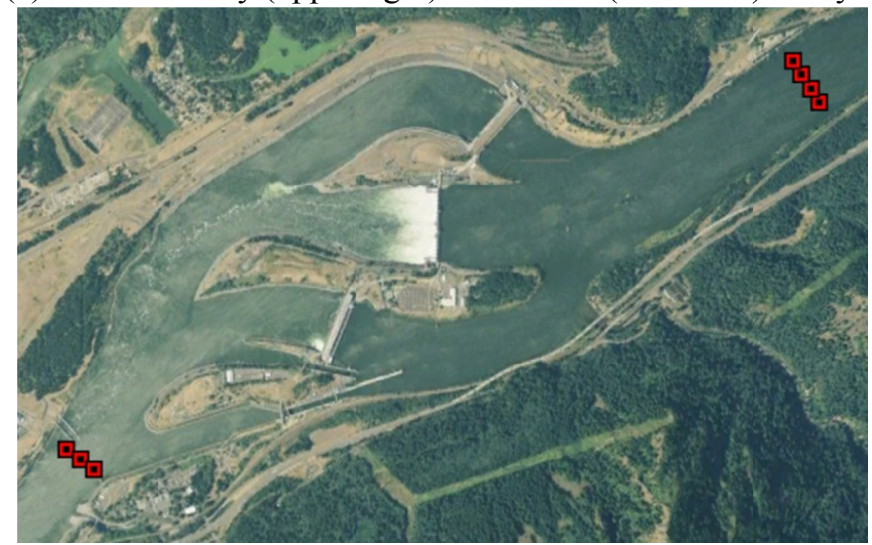

(b) Primary Survival Detection Array

(c) Secondary Survival Detection Array

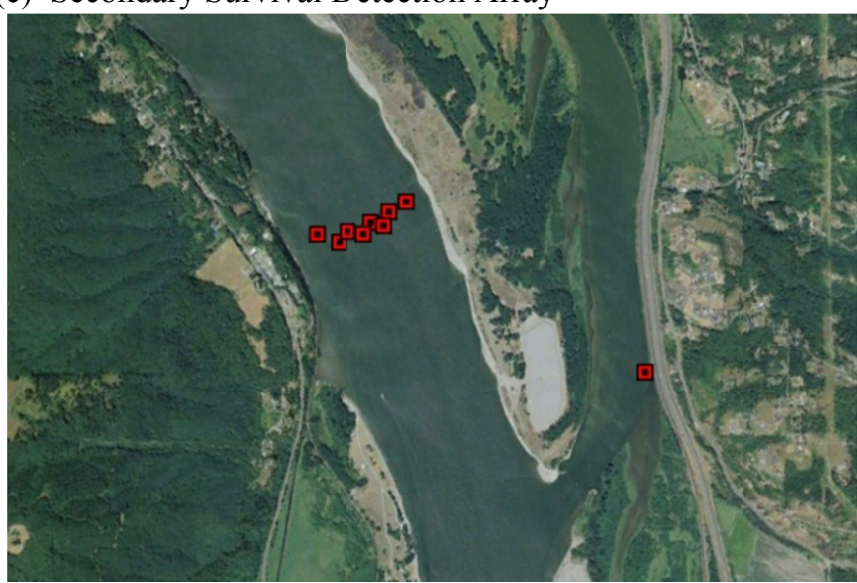

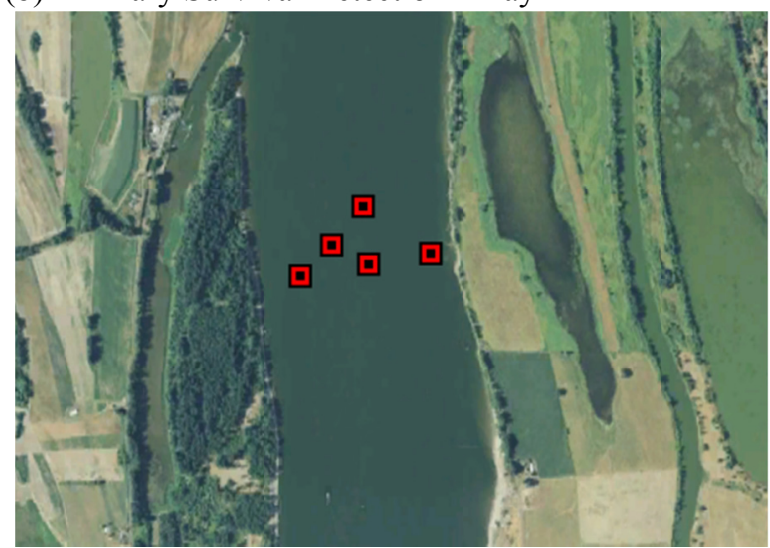

(d) Tertiary Survival Detection Array

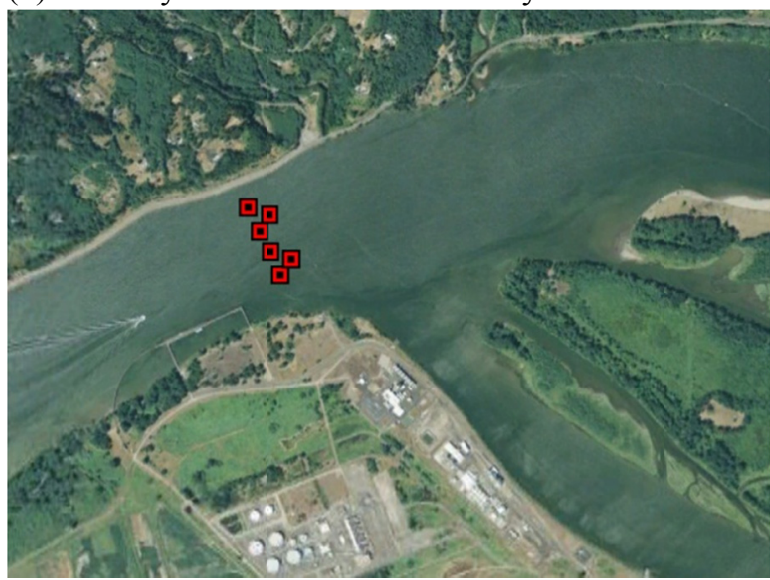

Figure 2.12. Locations of Autonomous Nodes in Study Arrays. Arrays were located in the BON forebay (CR236) and tailrace (CR233) (Panel a), the primary array near Knapp, Washington, about $10 \mathrm{~km}$ downstream of the Columbia and Willamette River confluence (CR153; Panel b), the secondary array near Kalama, Washington (CR113; Panel c), and tertiary array near Oak Point, Washington (CR086; Panel d).

\subsubsection{Node Retrieval, Servicing, and Redeployment}

Autonomous nodes were first deployed in late April, retrieved every 2 weeks to download data, and redeployed. Batteries were replaced every 28 days. The last recovery data in 2010 was on August 9 . The post-FCRPS study deployed and serviced the Kalama and Oak Point arrays monthly. These post-FCRPS arrays were used as secondary and tertiary survival arrays, respectively. The first step in servicing a node was to trigger its acoustic release by entering a release-specific code into a transceiver to transmit an acoustic signal to the release mechanism to free the acoustic release and node from the anchor. After the 
node, floats, and acoustic release surfaced, they were retrieved by boat (Figure 2.13). The next step was to dry the node with a towel, open it, eject the CF card, and download data from the card to a laptop computer. The data file was checked to verify that the node collected data throughout its deployment, records were continuous, and records included time stamps and tag detections. The CF card was replaced every time nodes were retrieved. When data were corrupt, the node top was replaced with a new one and the faulty top was sent to Sonic Concepts in Seattle for repair. The most common problem was damage to the hydrophone tip.

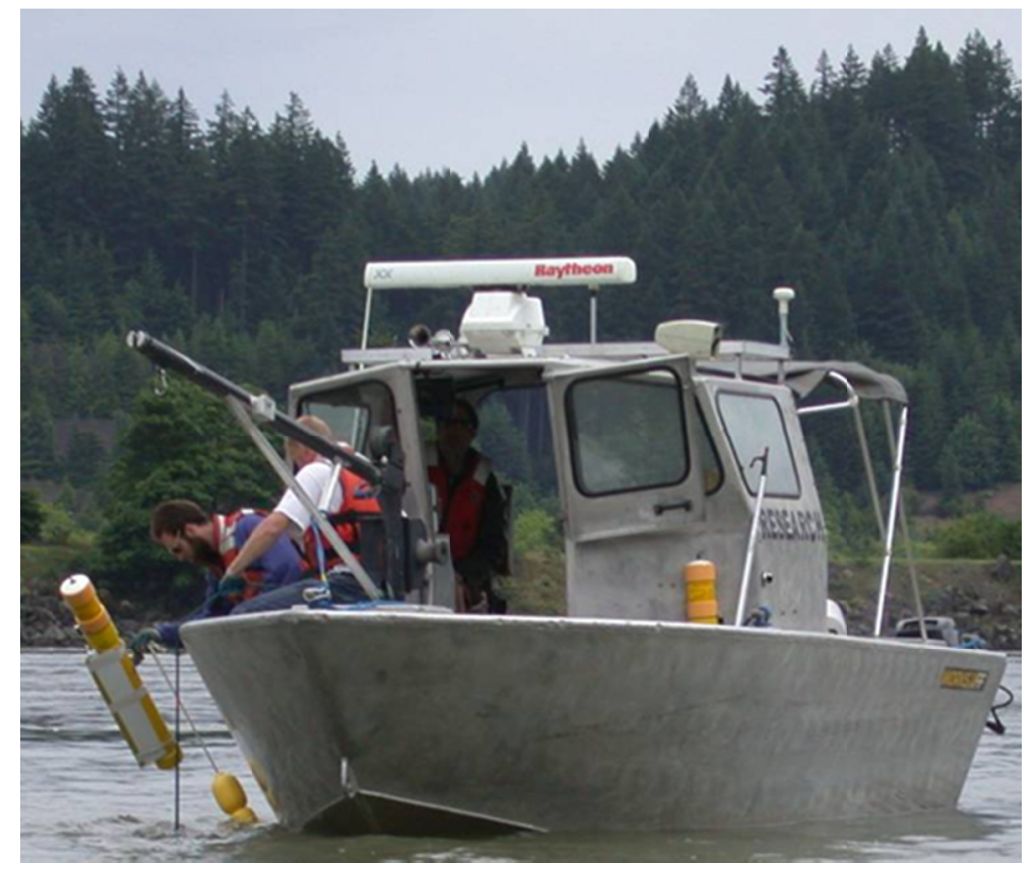

Figure 2.13. Autonomous Node Retrieval

\subsection{Project Discharge and Water Temperature}

Project discharge data by spill bay and turbine unit and forebay and tailwater elevations were acquired in 5-minute increments by the automated data-acquisition systems at BON and provided by the Portland District. Average discharge and forebay water temperature data from 1999 through 2008 were downloaded from the DART (Data Access in Real Time) website (http://www.cbr.washington.edu/dart) and plotted. Five-minute discharges for the entire project and spillway were averaged by day and plotted along with 10-year averages.

\subsection{Acoustic Signal Processing}

Processing of acoustic signals involved the use of binary waveform data files, filtering of decoded data, and tracking of fish movements. 


\subsubsection{Binary Waveform Data Files}

Data collected by the JSATS cabled hydrophones were encoded candidate messages saved in binary time-domain waveform files. Figure 2.13 shows the waveforms of an actual example acquired at the JDA spillway on June 18, 2008. The waveform files were then processed by a decoding utility (Waveform Utilities developed by the USACE and PNNL) that identifies valid tag signals and computes the tag code and time of arrival using Binary Phase Shift keying. Binary Phase Shift keying is a digital-modulation technique that transmits messages by altering the phase of the carrier wave. Several filtering algorithms were then applied to the raw results from the decoding utilities to exclude spurious data and false positives.
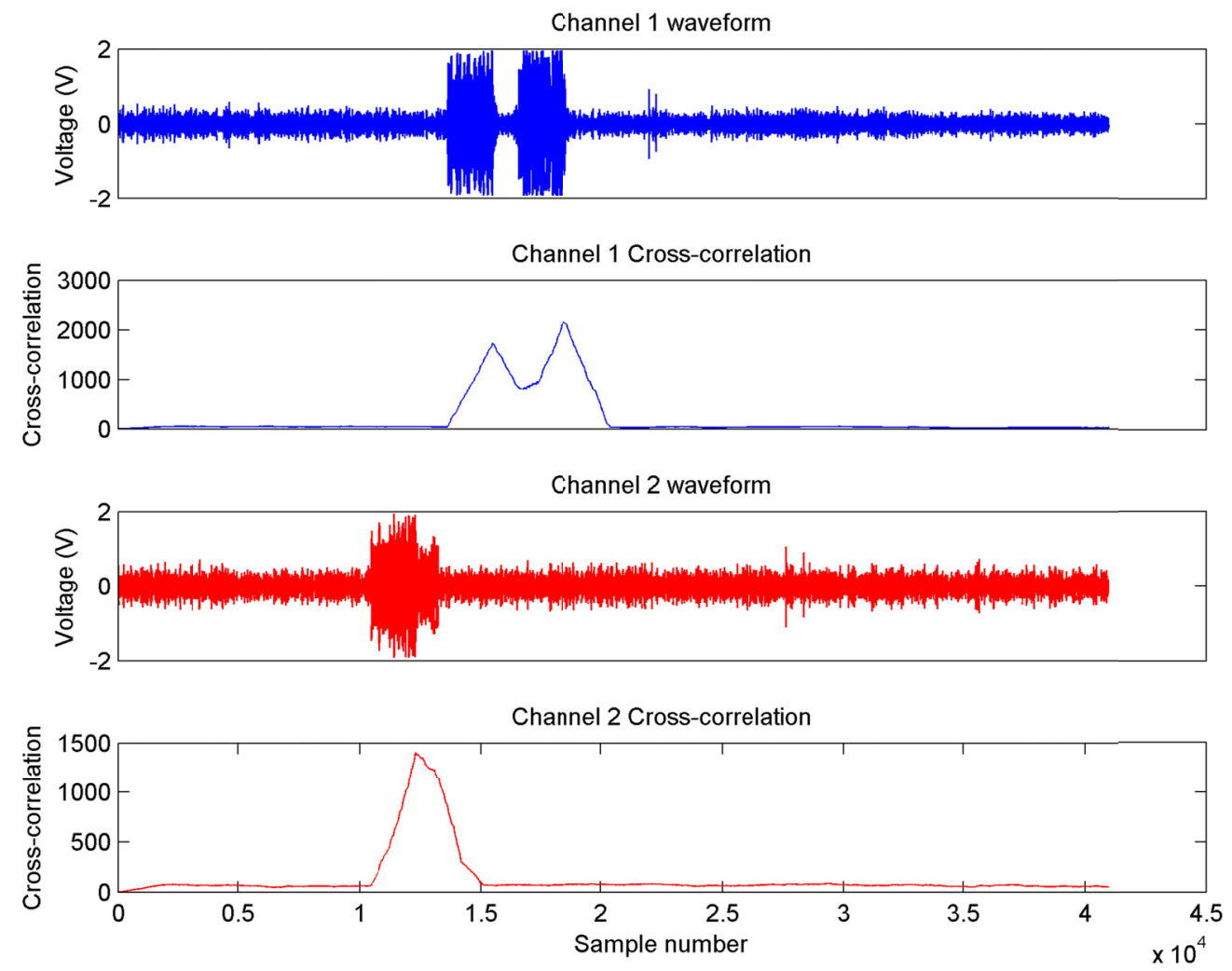

Figure 2.14. Example of Time-Domain Waveforms and Corresponding Cross-Correlations Acquired at the John Day Dam Spillway. The message portion was 1860 samples ( $744 \mu$ s long). Note that multipath components were present in both channels. Decodes from the multipath components were filtered out in post-processing.

Transmissions of JSATS tag codes received on cabled and autonomous hydrophones were recorded in raw data files. These files were downloaded periodically and transported to PNNL offices in North Bonneville and Richland, Washington, for processing. 


\subsubsection{Filtering Decoded Data}

Receptions of tag codes within raw data files were processed to produce a data set of accepted tagdetection events. For cabled arrays, detections from all hydrophones at a dam were combined for processing. The following three filters were used for data from cabled arrays:

- Multipath filter: For data from each individual cabled hydrophone, all tag-code receptions that occur within 0.156 seconds after an initial identical tag code reception were deleted under the assumption that closely lagging signals are multipath. Initial code receptions were retained. The delay of 0.156 seconds was the maximum acceptance window width for evaluating a pulse repetition interval (PRI) and was computed as 2(PRI_Window+12×PRI_Increment). Both PRI_Window and PRI_Increment were set at 0.006 , which was chosen to be slightly larger than the potential rounding error in estimating PRI to two decimal places.

- Multi-detection filter: Receptions were retained only if the same tag code was received at another hydrophone in the same array within 0.3 seconds because receptions on separate hydrophones within 0.3 seconds (about $450 \mathrm{~m}$ of range) were likely from a single tag transmission.

- PRI filter: Only those series of receptions of a tag code (or "messages") that were consistent with the pattern of transmissions from a properly functioning JSATS acoustic tag were retained. Filtering rules were evaluated for each tag code individually, and it was assumed that only a single tag would be transmitting that code at any given time. For the cabled system, the PRI filter operated on a message, which included all receptions of the same transmission on multiple hydrophones within 0.3 seconds. Message time was defined as the earliest reception time across all hydrophones for that message. Detection required that at least six messages were received with an appropriate time interval between the leading edges of successive messages.

Like the cabled-array data, receptions of JSATS tag codes within raw autonomous node data files are processed to produce a data set of accepted tag detection events. A single file is processed at a time, and no information on receptions at other nodes is used. The following two filters are used during processing of autonomous node data:

- Multipath filter: Same as for the cabled-array data.

- PRI filter: Retain only those series of receptions of a tag code (or "hits") that were consistent with the pattern of transmissions from a properly functioning JSATS acoustic tag. Each tag code was processed individually, and it was assumed that only a single tag will be transmitting that code at any given time.

The output of the filtering processes for both cabled and autonomous hydrophones was a data set of events that summarized accepted tag detections for all times and locations where hydrophones were operating. Each unique event record included a basic set of fields that indicated the unique identification number of the fish, the first and last detection time for the event, the location of detection, and how many messages were detected within the event. This list was combined with accepted tag detections from the autonomous arrays and PIT-tag detections for additional quality assurance/quality control analysis prior to survival analysis. Additional fields captured specialized information, where available. One such example was route of passage, which was assigned a value for those events that immediately preceded passage at a 
dam based on spatial tracking of tagged fish movements to a location of last detection. Multiple receptions of messages within an event can be used to triangulate successive tag positions relative to hydrophone locations.

One of the most important quality control steps was to examine the chronology of detections of every tagged fish on all arrays above and below the dam-face array to identify any detection sequences that deviated from the expected upstream to downstream progression through arrays in the river. Except for possible detections on forebay entrance arrays after detection on a nearby dam-face array 1 to $3 \mathrm{~km}$ downstream, apparent upstream movements of tagged fish between arrays that were greater than $5 \mathrm{~km}$ apart or separated by one or more dams were very rare $(<0.015 \%)$ and probably represented false positive detections on the upstream array. False positive detections usually will have close to the minimum number of messages and were deleted from the event data set before survival analysis.

\subsubsection{Tracking Fish Movements}

Tagged fish in the immediate forebay of BON were tracked in three dimensions to determine routes of passage into the $\mathrm{B} 1$ surface-flow outlets and $\mathrm{B} 2 \mathrm{CC}$ passage efficiency, and some combination of 3D, $2 \mathrm{D}$, and last detection was used to assign other routes of passage through the dam. Acoustic tracking is a common technique in bioacoustics based on time-of-arrival differences among different hydrophones. Usually, the process requires a three-hydrophone array for 2D tracking and a four-hydrophone array for 3D tracking. Our methods for 3D tracking are described in detail by Deng et al. (2011a).

\subsection{Statistical Methods}

The statistical methods include tests of assumptions and estimation of dam-passage survival, forebayand dam-passage survival, travel times, passage efficiencies, and distributions.

\subsubsection{Tests of Assumptions}

There were several assumptions of the survival model that could be readily tested. The following table describes survival model assumptions and subsequent sections describe testing conducted in 2010 .

As explained in the Statistical Design for the Lower Columbia River Acoustic-Tag Investigations of Dam Passage Survival and Associated Metrics by Skalski (2009), the assumptions of the virtual singlerelease model and tests of the assumptions are as follows:

\begin{tabular}{ll}
\hline \multicolumn{1}{c}{ Assumption } & \multicolumn{1}{c}{ Test } \\
\hline $\begin{array}{l}\text { A1. Individuals marked for the study } \\
\text { are a representative sample from the } \\
\text { population of inference. }\end{array}$ & $\begin{array}{l}\text { Compare run timing distributions for the test fish versus the smolt } \\
\text { monitoring data by species. Compare fish size and other fitness measures } \\
\text { between tagged fish and run-at-large. }\end{array}$ \\
$\begin{array}{ll}\text { A2. All sampling events are } \\
\text { "instantaneous." That is, sampling } \\
\text { occurs over a negligible distance } \\
\text { relative to the length of the intervals } \\
\text { between sampling events. }\end{array}$ & $\begin{array}{l}\text { No time a tagged fish spends at a sampling array is relatively } \\
\text { brief compared to the time of travel between arrays. }\end{array}$
\end{tabular}




\section{Assumption}

A3. The fate of each tagged individual is independent of the fate of all others.

A4. All tagged individuals alive at a sampling location have the same probability of surviving until the end of that event.

A5. All tagged individuals alive at a sampling location have the same probability of being detected on that event.

A6. All tags are correctly identified and the status of smolt (i.e., alive or dead) is correctly assessed.

A7. Survival in the lower river segment of the first reach is conditionally independent of survival in the upper river segment.

A8. The virtual release group is constructed of tagged fish known to have passed through the dam.

A9. All fish arriving at the dam have an equal probability of inclusion in the virtual release group, independent of passage route through the dam.
Test

No test; commonly accepted as true in tagging studies.

Tests 2 and 3 of Burnham et al. (1987) can be used to assess whether upstream detection has an effect on downstream survival.

No test; this assumption is satisfied by placing hydrophone arrays across the breadth of the river so that all fish, regardless of location, have the same probability of detection. Lab-derived tag-life and tag-expulsion data will be used to assess this assumption.

Releases of dead tagged fish at the dams will be used to confirm the absence of false positive detections due to fish dying during dam passage but being detected downriver. Further, if dead fish are detected at the first detection array downstream of the dam, deployment of multiple additional arrays will allow flexibility to select arrays farther downstream to ensure this assumption is not violated. In addition, because tag loss or failure would violate the assumption, we will perform laboratory tag-life assessments. Release teams checked every bucket carefully for dropped acoustic and PIT tags before releasing fish.

Comparison of the survival estimates through the two downstream reaches formed by the three below-dam hydrophone arrays for the three release groups can therefore be used to help assess the validity of this assumption. Laboratory tagging effects research using run-of-river untagged, PIT-only, and AT+PIT groups collected at the time of tagging and through the sort-by-code systems will be used to assess this assumption. Survival by release location and river reach will be assessed to test for tagging effects.

A double-detection array in the forebay increases detection probabilities close to 1.0 and will be used to test for homogeneous detection rates.

This assumption is met by having very high detection probabilities on dam-face arrays. Thus, we will estimate array detection probabilities.

\subsubsection{Probability of Detection}

Detection probabilities are an integral part of the survival estimation. For any particular passage route the following variables are defined based on detection on two independent hydrophone arrays at the dam face:

- $n_{10}=$ number of tagged smolts detected by the first array but not the second

- $n_{01}=$ number of tagged smolts detected at the second array but not the first

- $n_{11}=$ number of tagged smolts detected at both the first and second arrays. 
From these counts of smolts with various route-specific detection histories, absolute passage abundance $(\hat{N})$ of tagged smolts can be estimated as

$$
\hat{N}=\frac{\left(n_{10}+n_{11}+1\right)\left(n_{01}+n_{11}+1\right)}{\left(n_{11}+1\right)}-1
$$

or

$$
\hat{N}=\frac{\left(n_{1}+1\right)\left(n_{2}+1\right)}{\left(n_{11}+1\right)}-1
$$

where $n_{1}=n_{10}+n_{11}$ and $n_{2}=n_{01}+n_{11}$ with associated variance estimate (Seber 1982)

$$
\widehat{\operatorname{Var}}(\hat{N})=\frac{\left(n_{1}+1\right)\left(n_{2}+1\right)\left(n_{1}-n_{11}\right)\left(n_{2}-n_{11}\right)}{\left(n_{11}+1\right)^{2}\left(n_{11}+2\right)}
$$

The estimated probability of detection $\left(p_{1}\right)$ in the first array is calculated as

$$
\hat{p}_{1}=\frac{n_{11}}{n_{2}}
$$

and the probability of detection $\left(p_{2}\right)$ in the second array as

$$
\hat{p}_{2}=\frac{n_{11}}{n_{1}}
$$

The overall probability of a smolt being detected in the double-array system is given by

$$
\hat{P}=1-\left(1-\hat{p}_{1}\right)\left(1-\hat{p}_{2}\right)=\frac{n_{11}\left(n_{1}+n_{2}+n_{11}\right)}{n_{1} n_{2}}
$$

We estimated passage abundance and the proportion of fish passing through every route through the dam (i.e., B1 sluiceway, B1 turbines, spillway, B2CC, B2 JBS, B2 turbines) as well as for composite routes such as B1 (B1 sluiceway and B1 turbines) or B2 (B2CC, B2 JBS, and B2 turbines). For example, the proportion of the acoustic-tagged smolts passing through the $\mathrm{B} 2 \mathrm{CC}\left(\hat{P}_{B 2 C C}\right)$ was estimated as follows:

$$
\hat{P}_{\text {B2CC }}=\frac{\hat{N}_{\text {B2CC }}}{\hat{N}_{\text {B1_sluiceway }}+\hat{N}_{\text {B1_turbines }}+\hat{N}_{\text {Spill }}+N_{\text {B2CC }}+\hat{N}_{\text {B2_JBS }}+N_{\text {B2_turbines }}},
$$

where $N_{\mathrm{i}}$ is the absolute passage through the $i$ th route, as described above. 


\subsubsection{Burnham et al. 1987 Tests}

Tests 2 and 3 of Burnham et al. (1987) have been used to assess whether upstream detection history has an effect on downstream survival. Such tests are most appropriate when fish are physically recaptured or segregated during capture as in the case with PIT-tagged fish going through the JBS. However, acoustic-tag studies do not use physical recaptures to detect fish. Consequently, there is little or no relevance of these tests in acoustic-tag studies. Furthermore, the very high detection probabilities present in acoustic-tag studies frequently preclude calculation of these tests. For these reasons, these tests were not performed.

\subsubsection{Tests of Mixing}

Evaluation of homogeneous arrival of release groups at downriver detection sites was based on graphs of arrival distributions. The graphs were used to identify any systematic and meaningful departures from mixing. Ideally, the arrival distributions should overlap one another with similarly timed modes.

\subsubsection{Tagger Effects}

Subtle differences in handling and tagging techniques can have an effect on the survival of acoustictagged smolts used in the estimation of dam-passage survival. For this reason, tagger effects on juvenile STH and CH1 smolts were evaluated as part of the compliance study at TDA (Skalski et al. 2010a, b). In that analysis, the single release-recapture model was used to estimate reach survivals for fish tagged by different individuals. The analysis evaluated whether any consistent pattern of reduced reach survivals existed for fish tagged by any of the tagging staff.

For $k$ independent reach survival estimates, a test of equal survival was performed using the $F$-test

$$
F_{k-1, \infty}=\frac{s_{\hat{S}}^{2}}{\left(\frac{\sum_{i=1}^{k} \operatorname{Var}\left(\hat{S}_{i} \mid S_{i}\right)}{k}\right)}
$$

where $s_{\hat{S}}^{2}=\frac{\sum_{i=1}^{k}\left(\hat{S}_{i}-\hat{\bar{S}}\right)^{2}}{k-1}$ and $\hat{\bar{S}}=\frac{\sum_{i=1}^{k} \hat{S}_{i}}{k}$.

The $F$-test was used in evaluating tagger effects.

\subsubsection{Tag-Life Study}

All tags for the spring season were delivered prior to April 23, 2010, and tags from all manufacturing dates were randomly mixed prior to the use of any tags. After mixing, 49 tags were randomly selected for a spring tag-life assessment. Similarly, all tags for summer deployments were delivered prior to the tagging of any fish during the summer tagging season and following mixing, 50 tags were removed randomly for a summer tag-life assessment. As described by Skalski (2009), “....tag loss and tag failure 
would also violate Assumption A6" (see Assumption Testing above). The possibility of acoustic-tag failure depends on travel time relative to battery life. A tag-life curve was constructed for the spring tags and the summer tags. Tag-life curves and the cumulative percent of tags passing survival-detection arrays downstream of each dam were plotted together as a function of time since tag activation. We made taglife corrections to survival estimates, as described in the next section based upon the method described by Townsend et al. (2006).

\subsubsection{Estimation of Survival Rates}

The design for estimating survival for fish passing through 2-km of forebay, the dam, and 81-km of tailwater or through just the dam and $81 \mathrm{~km}$ of tailwater was illustrated in Figure 2.1. Fish detections assigned to the virtual release at the dam face along subsequent capture histories on three survival detection arrays downstream of the dam were further divided by route of passage assignments or summer spill treatment to estimate route- or treatment-specific survival rates.

\subsubsection{Processing Software and Approach}

The 2010 study was a virtual single-release study design in which fish from multiple upstream releases that were detected either by the forebay entrance array or by the dam-face array were entered into a virtual release group specific to one of those arrays. We used TagPro software to select fish releases and detection sites from the 2010 database. TagPro software is an acoustic-tag data preprocessor for survival estimation software programs including Active Tag Life Adjusted Survival (ATLAS) and Survival Under Proportional Hazards SURPH (http://www.cbr.washington.edu/analysis.html). TagPro data files were loaded into ATLAS Version 1.2.1 (6/1/2011) to create virtual single-release capture history files. The three downstream survival detection arrays produced $2^{3}=8$ possible capture histories for each release group $(111,011,101,001,110,010,100$, and 000), where a 1 indicates detection, and a zero indicates no detection on each of three successive survival-detection arrays. For example, "111" indicates detection on all three arrays, whereas " 010 " indicates detection on the second array but not on the first or third arrays. The ATLAS User Manual (see Section 3.3, pages 34-40 in Lady et al. 2010) describes in detail analyses for several study designs including the virtual single-release design used in this study. Tags detected on the dam-face array and then detected or not detected on the three downstream survival detection arrays were in a single TagPro file used to estimate dam-passage survival for a specific run of fish studied. Those files were divided into smaller files according to route-of-passage criteria (B1 turbines, B1 surface-flow outlets, spillway, B2CC, B2 turbines, or B2 JBS) using the Statistical Analysis System (SAS) and resulting route-specific detection histories were analyzed separately in ATLAS using the virtual single-release option to obtain route-specific survival estimates for each run of fish. Similarly, we used SAS to divide large dam-passage TagPro detection files into smaller files according to the spill treatment in effect at the time that each tagged $\mathrm{CH} 0$ passed the dam in summer to provide estimates for each spill treatment. We also divided the summer dam-passage data by spill block and treatment.

\subsubsection{Tag-Life Corrections to Survival Rates}

A virtual release group is composed of fish known to have arrived alive at an acoustic array. These fish may be composed of individuals from multiple release groups upstream. As such, they may have had different times inriver and require different tag-life corrections. Assuming all fish in a virtual release 
have the same downstream survival and detection processes, their subsequent capture histories may be modeled by a joint likelihood (see pages 71 and 72 in Lady et al. 2010). The tag-life corrections for the virtual release site are the unconditional tag survival probabilities from the actual release site to the virtual release site. Corrections for downstream survival detection arrays are conditional tag survival

probabilities, given that the tags were alive at the virtual release site. Tag-life corrections for each release of fish detected at a virtual release site are used to calculate subsequent tag-life corrections at downstream arrays but are not used to directly adjust survival rates.

\subsubsection{Estimation of Travel Times}

Travel times associated with forebay residence and tailrace egress were estimated using medians and arithmetic averages, i.e.,

$$
\bar{t}=\frac{\sum_{i=1}^{n} t_{i}}{n}
$$

with the variance of $\bar{t}$ estimated by

$$
\widehat{\operatorname{Var}}(\bar{t})=\frac{\sum_{i=1}^{n}\left(t_{i}-\bar{t}\right)^{2}}{n(n-1)},
$$

and where $t_{i}$ was the travel time of the $i^{\text {th }}$ fish $(i=1, \ldots, n)$.

Various travel time metrics for individual fish passing the dam were determined as follows:

- Forebay residence time was calculated by subtracting the time of last detection on the dam-face array from the time of first detection on the forebay entrance array.

- 100-m forebay residence time was calculated by subtracting the time of last detection at the dam face from the time of first detection $100 \mathrm{~m}$ upstream of the dam face.

- Tailrace egress time was calculated by subtracting the time of last detection at the dam-face array from the time of last detection at the tailrace exit array downstream of the dam.

- Project passage time was calculated by subtracting the time of first detection on the forebay entrance array from the time of last detection on the tailrace egress array.

\subsubsection{Estimation of Passage Efficiencies}

Spill-passage efficiency was estimated by the fraction

$$
\widehat{\mathrm{SPE}}=\frac{\hat{\mathrm{N}}_{\text {spillway }}}{\hat{\mathrm{N}}_{\text {B1_sluice }}+\hat{\mathrm{N}}_{\text {B1_turbines }}+\hat{\mathrm{N}}_{\text {Spill }}+\hat{\mathrm{N}}_{\mathrm{B} 2 \mathrm{CC}}+\hat{\mathrm{N}}_{\mathrm{B} 2 \text { _JBS }}+\hat{\mathrm{N}}_{\text {B2_turbines }}},
$$

where $\mathrm{N}_{i}$ is the absolute passage through the $i$ th route through the dam. 
The double-detection array was used to estimate absolute abundance $(N)$ through a route using the single mark-recapture model (Seber 1982) independently at each route.

Calculating the variance in stages, the variance of $\widehat{\mathrm{SPE}}$ was estimated as

$$
\operatorname{Var}(\widehat{\mathrm{SPE}})=\frac{\widehat{\mathrm{SPE}}(1-\widehat{\mathrm{SPE}})}{\sum_{\mathrm{i}=1}^{3} \hat{\mathrm{N}}_{\mathrm{i}}}+\widehat{\mathrm{SPE}}^{2}(1-\widehat{\mathrm{SPE}})^{2} \times\left[\frac{\operatorname{Var}\left(\hat{\mathrm{N}}_{\mathrm{B} 1}\right)+\operatorname{Var}\left(\hat{\mathrm{N}}_{\mathrm{B} 2}\right)}{\left(\hat{\mathrm{N}}_{\mathrm{B} 1}+\hat{\mathrm{N}}_{\mathrm{B} 2}\right)^{2}}+\frac{\widehat{\operatorname{Var}}\left(\hat{\mathrm{N}}_{\text {spillway }}\right)}{\hat{\mathrm{N}}_{\text {spillway }}^{2}}\right]
$$

where $\hat{N}_{B 1}$ is the absolute number passing through B1 (B1 sluiceway $+\mathrm{B} 2$ turbine), and $\hat{N}_{B 2}$ is the absolute number passing through $\mathrm{B} 2(\mathrm{~B} 2 \mathrm{CC}+\mathrm{B} 2 \mathrm{JBS}+\mathrm{B} 2$ turbines).

Spillway + B2CC passage efficiency, as required by the 2008 Fish Accords, was calculated as

$$
\widehat{\mathrm{SPE}}_{2}=\frac{\hat{\mathrm{N}}_{\text {spillway }}+\hat{\mathrm{N}}_{\mathrm{B} 2 \mathrm{CC}}}{\hat{\mathrm{N}}_{\text {B1_sluice }}+\hat{\mathrm{N}}_{\mathrm{B} 1_{\text {_turbines }}}+\hat{\mathrm{N}}_{\text {Spillway }}+\hat{\mathrm{N}}_{\mathrm{B} 2 \mathrm{CC}}+\hat{\mathrm{N}}_{\mathrm{B} 2 \_ \text {_BB }}+\hat{\mathrm{N}}_{\text {B2_turbines }}},
$$

where $\mathrm{N}_{i}$ is the absolute passage through the $i$ th route through the dam. The variance of spillway $+\mathrm{B} 2 \mathrm{CC}$ passage efficiency was calculated using the delta method (Seber 1982:7-9):

$$
\operatorname{Var}\left(\widehat{\mathrm{SPE}}_{2}\right)=\frac{\widehat{\operatorname{SPE}}_{2}\left(1-\widehat{\mathrm{SPE}}_{2}\right)}{\sum_{\mathrm{i}=1}^{4} \hat{\mathrm{N}}_{\mathrm{i}}}+{\widehat{\mathrm{SPE}_{2}}}^{2}\left(1-\widehat{\mathrm{SPE}}_{2}\right)^{2} \times\left[\frac{\operatorname{Var}\left(\hat{\mathrm{N}}_{\mathrm{B} 1}\right)+\operatorname{Var}\left(\hat{\mathrm{N}}_{\mathrm{B} 2 \_\mathrm{BS}}\right)+\operatorname{Var}\left(\hat{\mathrm{N}}_{\mathrm{B} 2 \text { turbines }}\right)}{\left(\hat{\mathrm{N}}_{\mathrm{B} 1}+\hat{\mathrm{N}}_{\mathrm{B} 2 \_\mathrm{BB}}+\hat{\mathrm{N}}_{\mathrm{B} 2 \text { turbines }}\right)^{2}}+\frac{\widehat{\operatorname{Var}}\left(\hat{\mathrm{N}}_{\text {spillway }+\mathrm{B} 2 \mathrm{CC}}\right)}{\hat{\mathrm{N}}_{\text {spillway }}^{2}+\mathrm{B} 2 \mathrm{CC}}\right]
$$

where $\hat{N}=\hat{N}_{\text {spillway+B2CC }}+\hat{N}_{\text {B1 }}+\hat{N}_{\text {B2_JBS }}+N_{\text {B2_turbines }}$

Fish-passage efficiency was estimated by the fraction

$$
\widehat{\mathrm{FPE}}=\frac{\hat{\mathrm{N}}_{\text {Spillway }}+\hat{\mathrm{N}}_{B 1 \_ \text {sluice }}+\hat{\mathrm{N}}_{B 2 C C}+\hat{\mathrm{N}}_{B 2 \_J B S}}{\hat{N}} \text {, }
$$

where $\hat{N}$ is the sum of absolute passage through all routes at the dam. Calculating the variance in stages, the variance of $\widehat{\mathrm{FPE}}$ was estimated as

$$
\begin{aligned}
& \operatorname{Var}(\widehat{\mathrm{FPE}})=\frac{\widehat{\mathrm{FPE}}(1-\widehat{\mathrm{FPE}})}{\sum_{i=1}^{5} \hat{N}_{i}}+\widehat{\mathrm{FPE}}^{2}(1-\widehat{\mathrm{FPE}})^{2} \times \\
& {\left[\frac{\operatorname{Var}\left(\hat{\mathrm{N}}_{\text {Spill }}\right)+\operatorname{Var}\left(\hat{\mathrm{N}}_{\mathrm{B} 1 \_ \text {sluice }}\right)+\operatorname{Var}\left(\hat{\mathrm{N}}_{\mathrm{B} 2 \mathrm{CC}}\right)+\operatorname{Var}\left(\hat{\mathrm{N}}_{\mathrm{B} 2 \_\mathrm{BBS}}\right)}{\left(\hat{\mathrm{N}}_{\text {Spill }}+\hat{\mathrm{N}}_{\mathrm{B} 1 \_ \text {sluice }}+\hat{\mathrm{N}}_{\mathrm{B} 2 \mathrm{CC}}+\hat{\mathrm{N}}_{\mathrm{B} 2 \_\mathrm{JBS}}\right)^{2}}+\frac{\widehat{\operatorname{Var}}\left(\hat{\mathrm{N}}_{\mathrm{T}}\right)}{\hat{\mathrm{N}}_{\mathrm{T}}{ }^{2}}\right],}
\end{aligned}
$$


where $\hat{N}_{T}$ is the absolute number of fish passing through B1 and B2 turbines and other terms were defined previously.

\subsubsection{Estimation of Distributions}

The two- and three-dimensional tracks (Section 2.8.3) were used to determine forebay approach distributions and horizontal distributions of passage through the dam. Bonneville Dam provides a unique setting to study fish behavior and passage because it has two islands that separate the spillway from two powerhouses. For every fish detected more than once by the dam-face array, we examined the location of first and last detections at dam structures and used those records to evaluate behavior in the forebay upstream of the dam. Horizontal distributions of passage through the dam were evaluated among the three dam structures (B1, spillway, and B2) and among major passage routes through the dam. Vertical distributions were not evaluated except to differentiate between sluiceway- and turbine-passed fish at B1 and B2. 


\subsection{Results - Environmental Conditions}

Environmental conditions include river discharge, water temperature, and forebay elevation.

\subsection{River Discharge}

Total water discharge at BON in 2010 fluctuated between 150 and $275 \mathrm{kcfs}$ during the spring tagging period (Figure 3.1). These levels were consistently below the previous 10-year average. Starting in June, discharge increased to levels well above the 10-year average, peaking at $398 \mathrm{kcfs}$ on June 12 . After this peak, total outflow began a general decline, reaching $156 \mathrm{kcfs}$ at the end of the summer tagging period on July 14. By the end of this period total outflow fluctuated near the 10-year average.

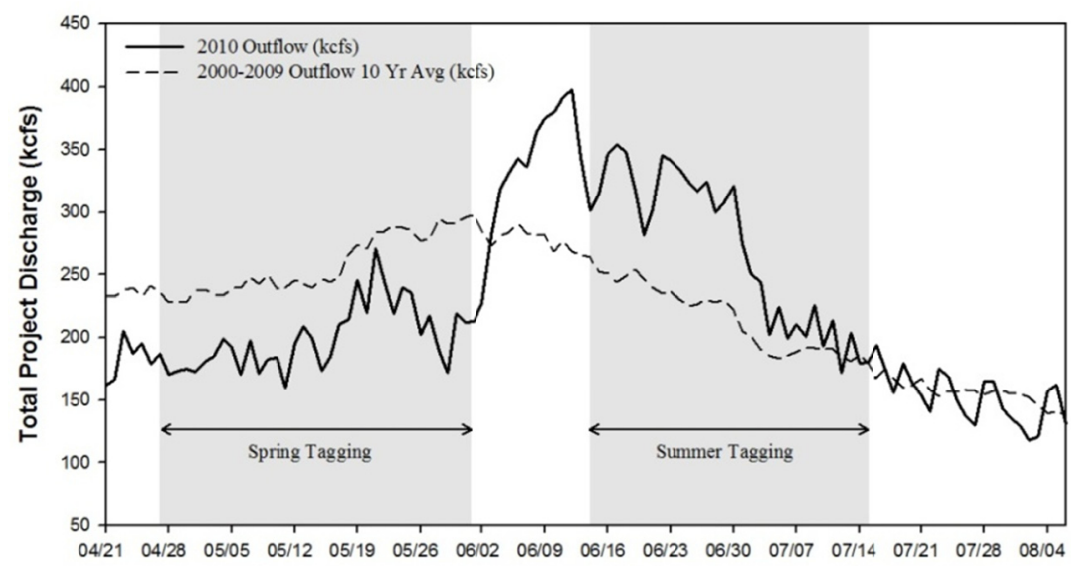

Figure 3.1. Average Daily Water Discharge (kcfs) from Bonneville Dam During the 2010 Study and for the Preceding 10-Year (2000-2009) Period

Daily spill discharge was within $25 \mathrm{kcfs}$ of the average for the previous 10 years until June 6 and higher than the average after June 6 (Figure 3.2).

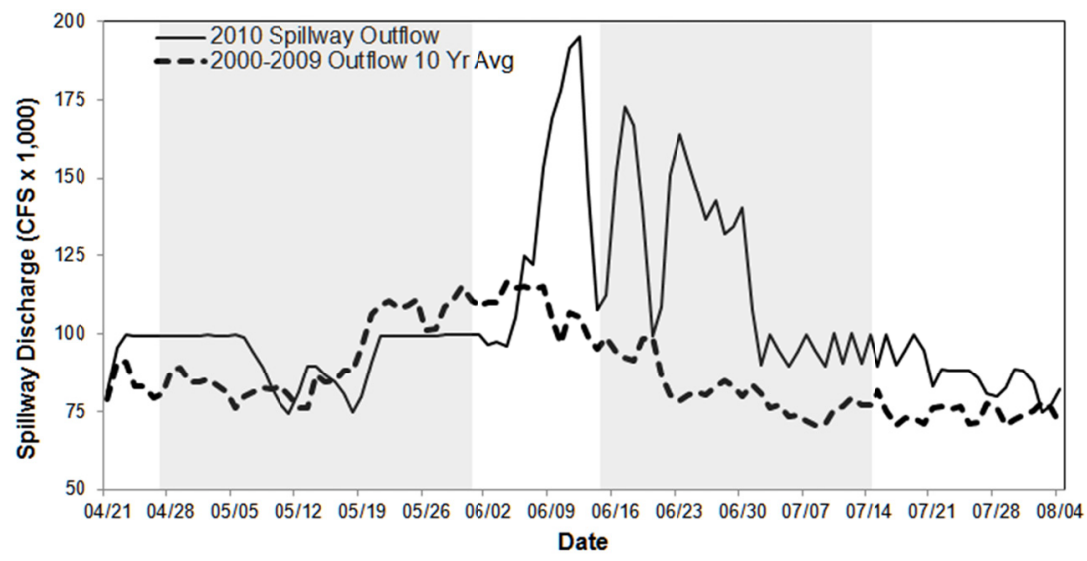

Figure 3.2. Daily Outflow and Spill Discharge of Water from Bonneville Dam for the Period from April 26 Through June 13, 2010 (labeled outflow and spill) and 10-Year Averages from 2000 Through 2009 


\subsection{Water Temperature}

The daily average water temperature for 2010 started at $11.3^{\circ} \mathrm{C}$ on April 28, very close to the previous 10-year average of $10.7^{\circ} \mathrm{C}$ (Figure 3.3). Temperatures steadily increased throughout the study, but by the end of the spring tagging season 2010 temperatures were $\sim 1.0-1.5^{\circ} \mathrm{C}$ below the 10 -year average. This trend continued through the end of July.

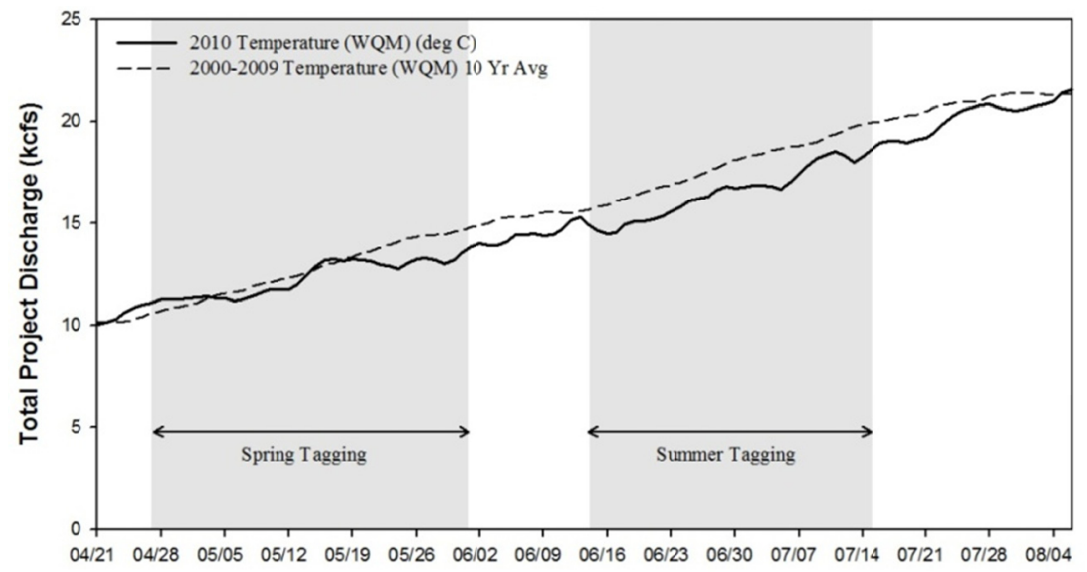

Figure 3.3. Bonneville Dam Average Daily Forebay Water Temperatures $\left({ }^{\circ} \mathrm{C}\right)$ During the 2010 Study and for the Preceding 10-Year Period

\subsection{Forebay Elevation}

In 2010, forebay elevation ranged from 73.14 to $77.77 \mathrm{ft}$ and averaged $75.34 \mathrm{ft}$ above MSL. The median elevation was identical to the mean (Figure 3.4).

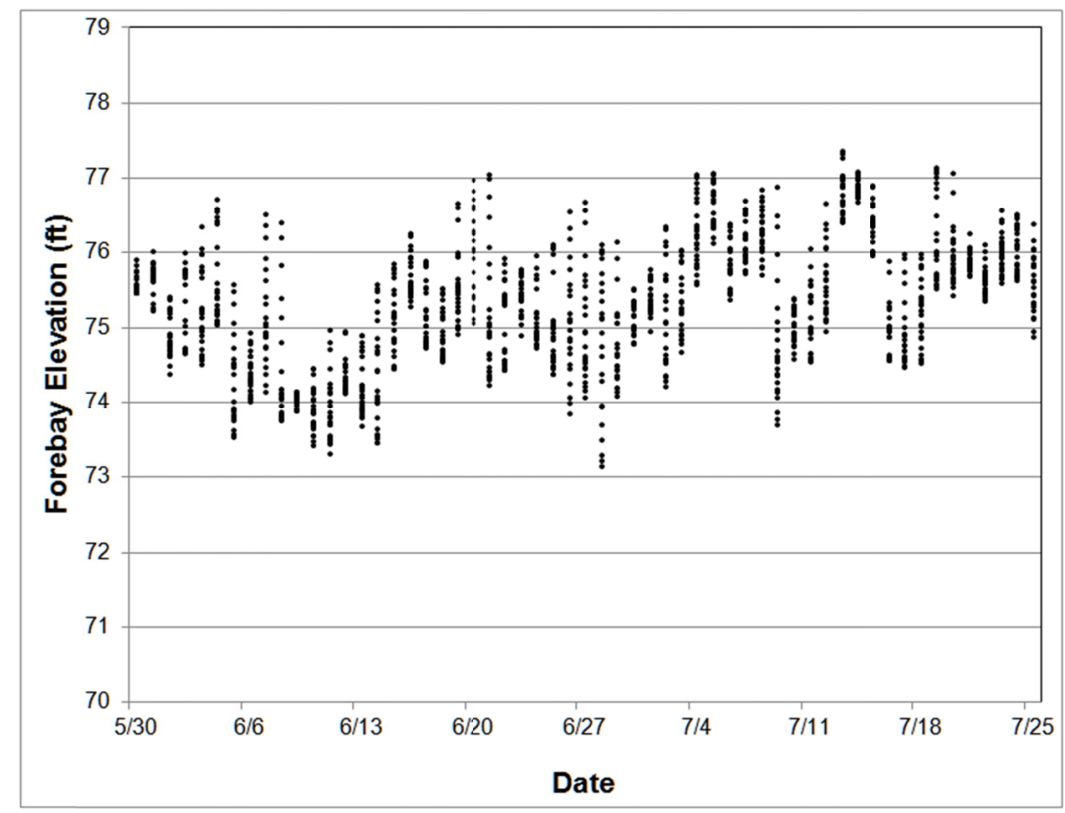

Figure 3.4. Bonneville Dam Hourly Estimates of Forebay Elevation. Elevation is in feet above MSL. 


\subsection{Summer Spill Treatments}

Spill treatments occurred from July 2-18, when river discharge had lowered to levels deemed manageable by the dam operators (Figure 3.5). There were eight consecutive treatments in total; each treatment was composed of a 2-day block. On the first day of each block, a randomly selected spill treatment was executed, followed by a second day with the alternative treatment. Spill treatments consisted of either $24 \mathrm{~h}$ of $95-\mathrm{kcfs}$ spill or a cycle of $85-\mathrm{kcfs}$ day and 120-kcfs night spill.

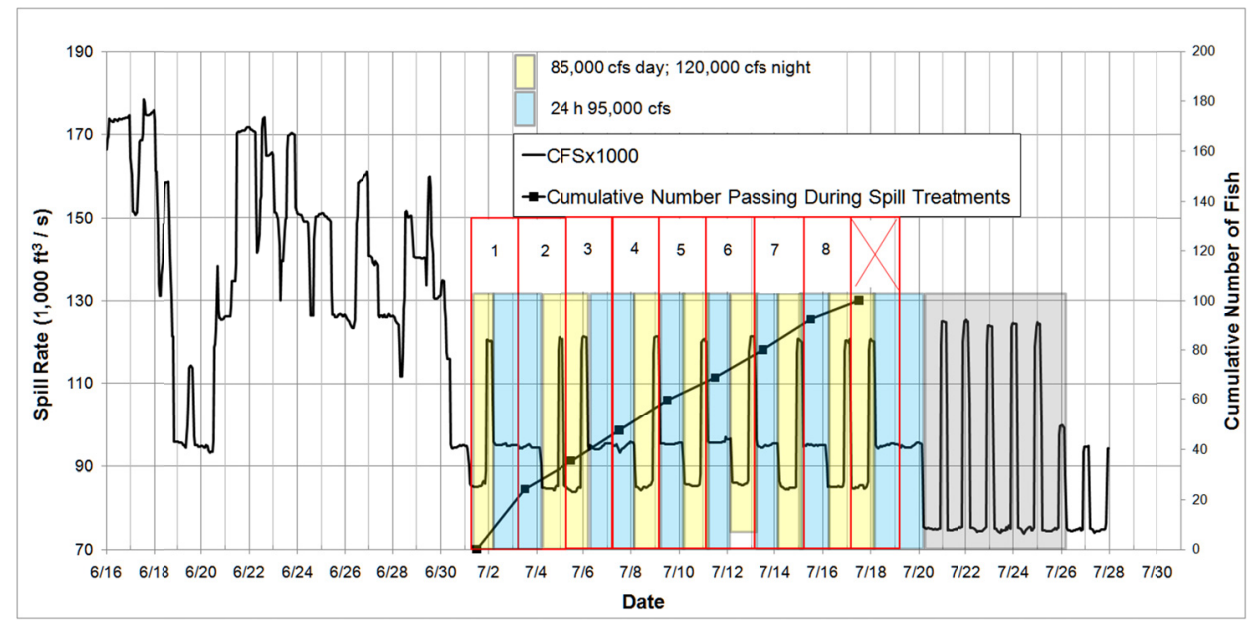

Figure 3.5. Plot of Spill Discharge Rate During Summer 2010 Showing Eight Successfully Realized Spill Treatment Blocks. Each block consisted of one randomly selected 1-day treatment followed by the alternative treatment. 


\subsection{Results - Yearling Chinook Salmon}

This section contains estimates of survival rates, travel times, passage efficiencies and distributions for $\mathrm{CH} 1$ at $\mathrm{BON}$ during spring 2010. Appendices to this report include related tagging and release data (Appendix A), hydrophone location data (Appendix B), capture history data (Appendix C), detection and survival probabilities (Appendix D), and an assessment of model assumptions (Appendix E).

The single-release design worked as conceived for CH1. Performance of the JSATS technology was good. The combined detection probability of the two independent dam-face arrays, based on a Lincoln Peterson index, exceeded $99 \%$ for every route, and detection probabilities of autonomous arrays were $>0.80$ for dam and forebay+dam-passage survival estimates (Appendix D.1 and D.2). Detection probabilities on survival detection arrays for dam $+81 \mathrm{~km}$ of tailwater passage and forebay + dam $+81 \mathrm{~km}$ of tailwater-passage survival estimates also exceeded $80 \%$. The survival model assumptions were met. The distribution of fish lengths for $\mathrm{CH} 1$ selected for tagging was very similar to the distribution for the same run in SMF samples at JDA (Figure E.1). Post-tagging mortality was only $0.1 \%$, and no acoustic tags were shed between the time of tagging and the time of release. Travel times were sufficiently short relative to tag life to adequately adjust the release-recapture data for tag failure (Figure E.4). For dampassage survival estimates, the probability that an acoustic tag was active at a downstream detection location was $>0.99$ (Table E.1; Figure E.5). Implementation produced near-perfect balance for the CH1 (Table E.4). Auxiliary analyses found no tagger effects (Table E.7) that might confound estimation of dam-passage survival. A separate release of 30 dead fish with active tags into the B2CC in spring 2010 resulted in no downstream detections at rkm 153,113, or 86. Downstream mixing of virtual release fish with reference release fish was not an issue because there were no reference releases of fish in the BON tailrace in 2010.

\subsection{Survival Estimates}

The single-release estimate of tag-life-adjusted dam passage for $\mathrm{CH} 1 V_{1}$ traveling from the BON dam-face array CR234 to detection array CR153 was calculated to be

$$
\hat{S}_{\text {BON \& Tailwater }}=\hat{S}_{1}=0.952
$$

with an associated standard error of 0.0040 . The standard error was based on both the multinomial sampling error of the release-recapture process and the sampling error associated with the estimation of the probabilities of tag activation. The single-release estimate of dam-passage survival for $\mathrm{CH} 1$ at BON in 2010 did not exceed the BiOp requirements of $\hat{S}_{\text {Dam }} \geq 0.960$ but the $\widehat{\mathrm{SE}}$ was $\leq 0.015$.

We also calculated a paired-release estimate of dam-passage survival by dividing the single-release estimate (above) by an estimate of B2CC-passage survival (0.9909; $\widehat{\mathrm{SE}}=0.0046)$ and that quotient met the BiOp standard:

$$
\frac{\hat{S}_{1}}{\hat{S}_{B 2 C C}}=\frac{0.9519}{0.9909}=0.9610 ; \quad \text { Paired } \widehat{\mathrm{SE}}=0.0060
$$


An estimate of forebay-to-tailrace-passage survival could not be calculated because there were no tailrace reference releases in 2010, so we made a single-release estimate of passage survival for yearlings passing through $2 \mathrm{~km}$ of forebay, the dam, and $81 \mathrm{~km}$ of tailwater:

$$
\hat{S}_{\text {forebay, dam, tailwater }}=0.951(\widehat{\mathrm{SE}}=0.0040)
$$

This estimate was 0.001 lower than the single-release estimate for passage through the dam and $81 \mathrm{~km}$ of tailwater, and presumably this difference represents mortality attributable to passage through $2 \mathrm{~km}$ of forebay.

Route-specific, single-release dam-passage survival estimates for $\mathrm{CH} 1$ were highest for the $\mathrm{B} 2 \mathrm{CC}$ (99.0\%), B1 turbines (98.7\%), B2 JBS (98.1), B1 sluiceway (98.0\%), B2 turbines $(95.7 \%)$, and the spillway (93.5\%; Table 4.1).

Table 4.1. Route-Specific Dam-Passage Survival Estimates for Yearling Chinook Salmon

\begin{tabular}{clccr}
\hline Metric & \multicolumn{1}{c}{ Route } & Estimate & SE & $\mathrm{n}$ \\
\hline Dam-Passage Survival & B2CC & 0.991 & 0.0046 & 634 \\
& B1 turbines & 0.987 & 0.0148 & 129 \\
& B2 JBS & 0.981 & 0.0104 & 218 \\
& B1 sluiceway & 0.980 & 0.0238 & 64 \\
& B2 turbines & 0.957 & 0.0093 & 533 \\
& Spillway & 0.935 & 0.0061 & 1766 \\
\hline
\end{tabular}

\subsection{Travel Times}

Median travel times for $\mathrm{CH} 1$ from the first detection on the forebay entrance array $2 \mathrm{~km}$ upstream of the dam until the last detection on the dam-face array was about $0.74 \mathrm{~h}$ and from the last dam-face detection until the last tailrace array detection was about $0.46 \mathrm{~h}$ (Table 4.2). The mean travel time was higher for forebay residence $(1.27 \mathrm{~h})$ than it was for tailrace egress $(0.94 \mathrm{~h})$. Mean and median travel times for project passage based on first detections on the forebay entrance array located $2 \mathrm{~km}$ upstream of the dam and last detections on the tailrace egress array were $2.21 \mathrm{~h}$ and $1.29 \mathrm{~h}$, respectively. There were no significant differences in travel time metrics between day and night time periods for $\mathrm{CH} 1$.

Table 4.2. Travel Times (h) for Yearling Chinook Salmon

\begin{tabular}{lrccc}
\hline \multicolumn{1}{c}{ Metric } & \multicolumn{1}{c}{$\mathrm{n}$} & Median & Mean & SE \\
\hline Forebay Residence (CR236 to CR234) & 3346 & 0.743 & 1.268 & 0.0456 \\
100-m Forebay Residence & 415 & 0.178 & 1.844 & 0.2675 \\
Tailrace Egress (CR234 to CR233) & 3246 & 0.455 & 0.943 & 0.1042 \\
Project Passage (CR236 to CR233) & 3259 & 1.290 & 2.213 & 0.1142 \\
\hline
\end{tabular}




\subsection{Passage Efficiencies}

Dam FPE was 11\% higher during daytime than it was at night on an absolute basis, and 95\% confidence intervals on those estimates did not overlap (Table 4.3). In examining FPE components, we observed that SPE was only 3.1\% higher during day than it was at night, but B2CC passage efficiency relative to the dam was a full $8 \%$ higher during the day than it was at night. Relative to $\mathrm{B} 2, \mathrm{~B} 2 \mathrm{CC}$ efficiency was $21.6 \%$ higher during the day than it was at night. B2 FGE also was higher during the day than it was at night by $17.1 \%$. Other day-night differences did not appear to differ significantly based on overlapping $95 \%$ confidence intervals.

Table 4.3. Passage Efficiencies for Yearling Chinook Salmon

\begin{tabular}{|c|c|c|c|c|}
\hline Metric & Period & Estimate & $\mathrm{SE}$ & $\mathrm{n}$ \\
\hline \multirow{3}{*}{ FPE } & Overall & 0.802 & 0.0069 & 3345 \\
\hline & Day & 0.842 & 0.0079 & 2156 \\
\hline & Night & 0.729 & 0.0129 & 1189 \\
\hline \multirow[t]{3}{*}{ SPE } & Overall & 0.528 & 0.0086 & 3345 \\
\hline & Day & 0.539 & 0.0107 & 2156 \\
\hline & Night & 0.509 & 0.0145 & 1189 \\
\hline \multirow[t]{3}{*}{$\mathrm{SPE}+\mathrm{B} 2 \mathrm{CC}$} & Overall & 0.717 & 0.0078 & 3345 \\
\hline & Day & 0.756 & 0.0092 & 2156 \\
\hline & Night & 0.647 & 0.0139 & 1189 \\
\hline \multirow[t]{3}{*}{ B1 Sluiceway $\|$ B1 = B1 FPE } & Overall & 0.330 & 0.0338 & 194 \\
\hline & Day & 0.292 & 0.0415 & 120 \\
\hline & Night & 0.392 & 0.0567 & 74 \\
\hline \multirow[t]{3}{*}{ B1 Sluiceway || Dam } & Overall & 0.019 & 0.0024 & 3345 \\
\hline & Day & 0.016 & 0.0027 & 2156 \\
\hline & Night & 0.024 & 0.0045 & 1189 \\
\hline \multirow[t]{3}{*}{$\mathrm{B} 2 \mathrm{CC} \| \mathrm{B} 2$} & Overall & 0.458 & 0.0134 & 1385 \\
\hline & Day & 0.539 & 0.0169 & 875 \\
\hline & Night & 0.322 & 0.0207 & 510 \\
\hline \multirow[t]{3}{*}{ B2CC $\|$ Dam } & Overall & 0.190 & 0.0068 & 3345 \\
\hline & Day & 0.218 & 0.0089 & 2156 \\
\hline & Night & 0.138 & 0.0100 & 1189 \\
\hline \multirow[t]{3}{*}{ B2 FGE } & Overall & 0.290 & 0.0166 & 751 \\
\hline & Day & 0.368 & 0.0240 & 405 \\
\hline & Night & 0.199 & 0.0215 & 346 \\
\hline \multirow[t]{3}{*}{ B2 JBS Passage Efficiency \| Dam } & Overall & 0.065 & 0.0043 & 3345 \\
\hline & Day & 0.069 & 0.0055 & 2156 \\
\hline & Night & 0.058 & 0.0068 & 1189 \\
\hline
\end{tabular}

\subsection{Passage Distributions}

The distributions of all detection events on the four forebay entrance array nodes were uniform, with only a slightly lower percent detected on the Washington shore node $(17.5 \%)$ than on the other three nodes toward the south, which accounted for 28,27 , and $28 \%$ of events, respectively. The distribution of passage at the three dam structures more closely followed the distribution of flow among the three structures than the distribution of detection events on the forebay array. The distribution of flow and fish 
passage through the dam was as follows: B1 passed $6 \%$ of yearlings in $13 \%$ of project flow; the spillway passed $52 \%$ of yearlings in $45 \%$ of river flow; B2 passed $42 \%$ of yearlings in $42 \%$ of flow. Over $99 \%$ of yearling Chinook passed through the Bonneville project at the dam structure where they were first detected, and this was true during high spill (spill $\geq 35 \%=99.8 \%)$ and low spill level $(<35 \%=99.2 \%$ ).

A plot of the distribution of passage among individual routes through the dam clearly shows that more $\mathrm{CH} 1$ passed through the spillway and B2 than through B1 (Figure 4.1). The plot also shows that surface-flow outlets passed a high percentage of fish at each powerhouse. Percent passage was slightly higher through end spill bays than through middle spill bays. Percent passage through the JBS was higher than the percent passing any individual turbine, and over half (52\%) of B2 turbine-passed yearlings went through three out of seven operational turbines at the south end of B2. If turbine 11 had not been out of service, the passage through southern B2 turbines likely would have been even higher.

\subsection{Effect of the B2 Behavioral Guidance System}

The mean B2CC passage efficiency for $\mathrm{CH} 1$ was $32.4 \%$ for the pre-BGS years and $44.9 \%$ for the post-BGS years - an increase of $12.5 \%$ (Table 4.4 ). A formal t-test only had $50.2 \%$ power to detect a significant difference, but a one-way hypothesis test that the post-BGS percentage was higher than the pre-BGS percentage was significant $(\mathrm{P}=0.0277)$ at a $5 \%$ level. The percent of turbine-passed yearlings decreased from an average of 44\% in 2004-2005 studies to an average of 32.6\% in 2008-2010 studies, a decrease of $11.4 \%$ (Table 4.4). This difference was not significant above the level of chance $(\alpha=0.05)$ in a one-tailed t-test $(\mathrm{P}=0.0618)$, but power to detect differences was low.

Table 4.4. Passage Percentage for Tagged Yearling Chinook Salmon Migrating Downstream Through B2CC and B2 Turbine Routes. Data from 2004 and 2005 are from U.S. Geological Survey radio-telemetry studies (Counihan et al. 2006a and b, respectively), and data from 2008, 2009, and 2010 are from the PNNL acoustic-telemetry studies (Faber et al. 2010, 2011; this study, respectively).

\begin{tabular}{cccc}
\hline Year & B2CC & Turbine & BGS \\
\hline 2004 & 35.5 & 43.5 & none \\
2005 & 29.3 & 44.0 & none \\
2008 & 49.0 & 33.0 & installed \\
2009 & 40.0 & 40.0 & installed \\
2010 & 45.8 & 25.2 & Installed \\
\hline
\end{tabular}




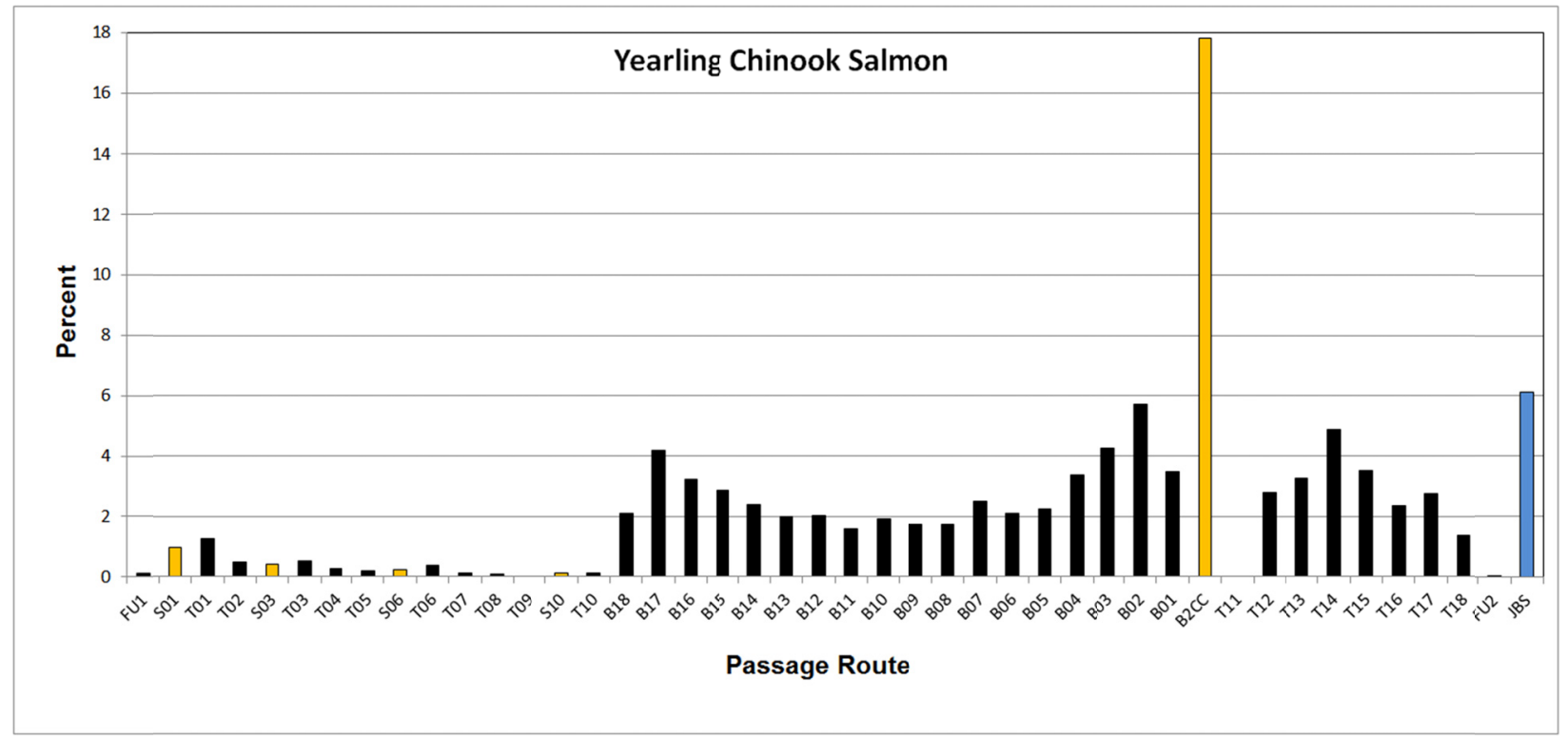

Figure 4.1. Horizontal Distribution of Yearling Chinook Salmon Passage in Spring 2010. Percent passage through surface-flow outlets (S01, S03, S06, S10, and the B2CC) are shown as gold bars, and B1 outlets are displayed to the left of the adjacent turbine with the same number, although they are actually physically located above the adjacent turbines. Abbreviations are as follows FU = fish units; S01, S03, S06, S10 = B1 sluiceway outlets; T1-T10= $\mathrm{B} 1$ turbines; $\mathrm{B} 01-\mathrm{B} 18=$ spill bays; $\mathrm{B} 2 \mathrm{CC}=\mathrm{B} 2$ Corner Collector; $\mathrm{T} 11-\mathrm{T} 18=\mathrm{B} 2$ turbines; $\mathrm{JBS}=\mathrm{B} 2$ juvenile bypass system. 


\subsection{Results - Juvenile Steelhead}

This section contains estimates of survival rates, travel times, passage efficiencies and distributions for juvenile STH at BON during spring 2010. Appendices to this report include related tagging and release data (Appendix A), hydrophone location data (Appendix B), capture history data (Appendix C), detection and survival probabilities (Appendix D), and an assessment of model assumptions (Appendix E).

The single-release design worked as conceived for juvenile STH. Performance of the JSATS technology was good. The combined detection probability of the two independent dam-face arrays, based on a Lincoln Peterson index, exceeded $99 \%$ for every route, and detection probabilities of autonomous arrays were $>0.75$ for dam $+81 \mathrm{~km}$ of tailwater and forebay + dam $+81 \mathrm{~km}$ of tailwater-passage survival estimates (Appendix D.9 and D.10). The survival model assumptions were met. The distribution of juvenile STH lengths selected for tagging was very similar to the distribution for the same run in SMF samples at JDA (Figure E.1). Post-tagging mortality was only $0.05 \%$, and no acoustic tags were shed between the time of tagging and the time of release. Travel times were sufficiently short relative to tag life to adequately adjust the release-recapture data for tag failure (Figure E.6). For dam-passage survival estimates, the probability that an acoustic tag was active at a downstream detection location was $>0.99$ (Table E.2). Study implementation produced near-perfect balance for the juvenile STH (Table E.5). Auxiliary analyses found no tagger effects (Table E.8) that might confound estimation of dam-passage survival. A separate release of 30 dead fish with active tags into the B2CC in spring 2010 resulted in no downstream detections at $\mathrm{rkm} 153,113$, or 86 . Downstream mixing of virtual release fish with reference release fish was not an issue because there were no reference releases of fish in the BON tailrace in 2010.

\subsection{Survival Estimates}

The single-release estimate of tag-life-adjusted dam passage for juvenile STH $V_{1}$ traveling from the BON dam-face array CR234 to detection array CR153 was calculated to be

$$
\hat{S}_{\text {BON \& Tailwater }}=\hat{S}_{1}=0.945
$$

with an associated standard error of 0.0043 . The standard error was based on both the multinomial sampling error of the release-recapture process and the sampling error associated with the estimation of the probabilities of tag activation. The single-release estimate of dam-passage survival for juvenile STH at BON in 2010 did not exceed the BiOp requirements of $\hat{S}_{\text {Dam }} \geq 0.960$ but the $\widehat{\text { SE }}$ was $\leq 0.015$.

A paired-release estimate of dam-passage survival also was calculated by dividing the single-release estimate (above) by an estimate of B2CC-passage survival $(0.975 ; \widehat{\mathrm{SE}}=0.0046)$ and that quotient met the BiOp standard:

$$
\frac{\hat{S}_{1}}{\hat{S}_{B 2 C C}}=\frac{0.945}{0.975}=0.969 ; \quad \text { Paired } \widehat{\mathrm{SE}}=0.0070
$$


An estimate of forebay-to-tailrace-passage survival could not be calculated because there were no tailrace reference releases in 2010, so a single-release estimate for juvenile STH passing through $2 \mathrm{~km}$ of forebay, the dam, and $81 \mathrm{~km}$ of tailwater was calculated:

$$
\hat{S}_{\text {forebay, dam, tailwater }}=0.944(\widehat{\mathrm{SE}}=0.0043) \text {. }
$$

This estimate was 0.001 lower than the single-release estimate for passage through the dam and $81 \mathrm{~km}$ of tailwater, and presumably this difference represents mortality attributable to passage through $2 \mathrm{~km}$ of forebay.

Route-specific, single-release dam-passage survival estimates for juvenile STH were highest for the B2 JBS (97.8\%), B2CC (97.5\%), B1 sluiceway (96.3\%), spillway (93.9\%), B2 turbines (0.911\%), and B1 turbines $(90.0 \%)$ (Table 5.1).

Table 5.1. Route-Specific Dam-Passage Survival Estimates for Juvenile Steelhead

\begin{tabular}{clccr}
\hline Metric & \multicolumn{1}{c}{ Route } & Estimate & SE & \multicolumn{1}{c}{$\mathrm{n}$} \\
\hline Dam-Passage Survival & B2 JBS & 0.978 & 0.0112 & 199 \\
& B2CC & 0.975 & 0.0054 & 1030 \\
& B1 sluiceway & 0.963 & 0.0260 & 80 \\
& Spillway & 0.939 & 0.0069 & 1364 \\
& B2 turbines & 0.911 & 0.0125 & 574 \\
& B1 turbines & 0.900 & 0.0284 & 116 \\
\hline
\end{tabular}

\subsection{Travel Times}

Median travel times for juvenile STH from the first detection on the forebay entrance array $2 \mathrm{~km}$ upstream of the dam until the last detection on the dam-face array was about $1.69 \mathrm{~h}$ and from the last dam-face detection until the last tailrace detection was about $0.41 \mathrm{~h}$ (Table 5.2). The mean travel time for forebay residence $(4.22 \mathrm{~h}$ ) was $3.8 \mathrm{~h}$ longer for than for tailrace egress $(0.42 \mathrm{~h})$. Median and mean travel times for project passage based on first detections on the forebay entrance array and last detections on the tailrace egress array were about $2.40 \mathrm{~h}$ and $5.32 \mathrm{~h}$, respectively. Median forebay residence time was significantly longer during the day $(2.32 \mathrm{~h})$ than it was at night (median $=1.19 \mathrm{~h})$, as was median project passage time (day $2.99 \mathrm{~h}$; night $=1.9 \mathrm{~h}$ ). Median estimates of $100-\mathrm{m}$ forebay residence time and tailrace egress time did not differ between day and night time periods.

Table 5.2. Travel Times (h) for Juvenile Steelhead

\begin{tabular}{lrrrl}
\hline \multicolumn{1}{c}{ Metric } & \multicolumn{1}{c}{$\mathrm{n}$} & \multicolumn{1}{c}{ Median } & \multicolumn{1}{c}{ Mean } & \multicolumn{1}{l}{ SE } \\
\hline Forebay Residence (CR236 to CR234) & 3358 & 1.687 & 4.219 & 0.1120 \\
100-m Forebay Residence & 435 & 1.426 & 6.060 & 0.5664 \\
Tailrace Egress (CR234 to CR233) & 3269 & 0.414 & 1.121 & 0.1351 \\
Project Passage (CR236 to CR233) & 3271 & 2.397 & 5.316 & 0.1765 \\
\hline
\end{tabular}




\subsection{Passage Efficiencies}

Dam FPE was $10.8 \%$ higher during daytime than it was at night on an absolute basis and 95\% confidence intervals on those estimates did not overlap (Table 5.3). In examining FPE components, SPE was observed to be $21.5 \%$ higher at night than it was during the day, so it could not help to explain why FPE was higher during the day than at night. The B2CC passage efficiency relative to the dam for juvenile STH was $31.1 \%$ higher during the day than it was at night. Relative to B2, B2CC passage efficiency for juvenile STH was 33.1\% higher during the day (72\%) than it was at night $(38.9 \%)$, and overall the B2CC passed $57.1 \%$ of juvenile STH that entered the B2 forebay. B2 FGE also was $9.8 \%$ higher during the day than it was at night. Other day-night differences did not differ significantly based on overlap of $95 \%$ confidence intervals.

Table 5.3. Passage Efficiencies for Juvenile Steelhead

\begin{tabular}{|c|c|c|c|c|}
\hline Metric & Period & Estimate & SE & $\mathrm{n}$ \\
\hline \multirow[t]{3}{*}{$\overline{F P E}$} & Overall & 0.795 & 0.0070 & 3363 \\
\hline & Day & 0.855 & 0.0090 & 1493 \\
\hline & Night & 0.747 & 0.0101 & 1870 \\
\hline \multirow[t]{3}{*}{ SPE } & Overall & 0.406 & 0.0085 & 3363 \\
\hline & Day & 0.287 & 0.0120 & 1493 \\
\hline & Night & 0.501 & 0.0116 & 1870 \\
\hline \multirow[t]{3}{*}{$\mathrm{SPE}+\mathrm{B} 2 \mathrm{CC}$} & Overall & 0.712 & 0.0078 & 3363 \\
\hline & Day & 0.766 & 0.0110 & 1493 \\
\hline & Night & 0.669 & 0.0109 & 1870 \\
\hline \multirow[t]{3}{*}{ B1 Sluiceway $\|$ B1 = B1 FPE } & Overall & 0.408 & 0.0351 & 196 \\
\hline & Day & 0.611 & 0.0570 & 72 \\
\hline & Night & 0.290 & 0.0408 & 124 \\
\hline \multirow[t]{3}{*}{ B1 Sluiceway || Dam } & Overall & 0.024 & 0.0026 & 3363 \\
\hline & Day & 0.029 & 0.0040 & 1493 \\
\hline & Night & 0.019 & 0.0032 & 1870 \\
\hline \multirow[t]{3}{*}{$\mathrm{B} 2 \mathrm{CC} \| \mathrm{B} 2$} & Overall & 0.571 & 0.0117 & 1803 \\
\hline & Day & 0.720 & 0.0140 & 993 \\
\hline & Night & 0.389 & 0.0171 & 810 \\
\hline \multirow[t]{3}{*}{ B2CC \| Dam } & Overall & 0.306 & 0.0079 & 3363 \\
\hline & Day & 0.479 & 0.0130 & 1493 \\
\hline & Night & 0.168 & 0.0087 & 1870 \\
\hline \multirow[t]{3}{*}{ B2 FGE } & Overall & 0.257 & 0.0157 & 773 \\
\hline & Day & 0.320 & 0.0280 & 278 \\
\hline & Night & 0.222 & 0.0187 & 495 \\
\hline \multirow[t]{3}{*}{ B2 JBS Passage Efficiency \| Dam } & Overall & 0.059 & 0.0041 & 3363 \\
\hline & Day & 0.060 & 0.006 & 1493 \\
\hline & Night & 0.059 & 0.0054 & 1870 \\
\hline
\end{tabular}




\subsection{Passage Distributions}

The distributions of all detection events on the four forebay entrance array nodes were uniform, with only a slightly lower percent detected on the Washington shore node $(16.9 \%)$ than on the other three nodes toward the south, which accounted for 28,27 , and $28 \%$ of STH detection events, respectively. The distribution of passage at the three dam structures more closely followed the distribution of flow among the three structures than the distribution of detection events on the forebay array. The distribution of flow and fish passage through the dam was as follows: B1 passed $6 \%$ of STH in 13\% of project flow; the spillway passed $40 \%$ of STH in $45 \%$ of river flow; B2 passed $54 \%$ of STH in $42 \%$ of flow. Only $88 \%$ of juvenile STH passed through the Bonneville project at the dam structure where they were first detected, and this was true during high spill (spill $\geq 35 \%=88.5 \%)$ and low spill levels $(<35 \%=87.6 \%)$. Of the $352 \mathrm{STH}$ that passed at an alternate structure than where first detected, $88.9 \%$ entered but subsequently rejected the spillway. Out of the 1,638 STH that first approached the spillway, 313 (19.1\%) subsequently passed at one of the powerhouses. About $91 \%$ of milling STH $(n=286)$ that first approached the spillway passed at B2. In contrast, only $2.2 \%(n=39)$ of STH that approached either B1 $(n=202)$ or B2 $(\mathrm{n}=1569)$ passed at another dam structure.

A plot of the distribution of passage among individual routes through the dam clearly shows that more juvenile STH passed through the spillway and B2 than through B1 (Figure 5.1) and that surfaceflow outlets passed a high percentage of fish at each powerhouse. Percent passage was slightly higher through end spill bays 2-3 and 16-18 than through most other bays in the middle of the spillway. Percent passage through the JBS was higher than the percent passing all but one turbine, and $61.5 \%$ of B2 turbine-passed STH went through three out of seven operational turbines at the south end of B2 even though turbine 11 was out of service all spring.

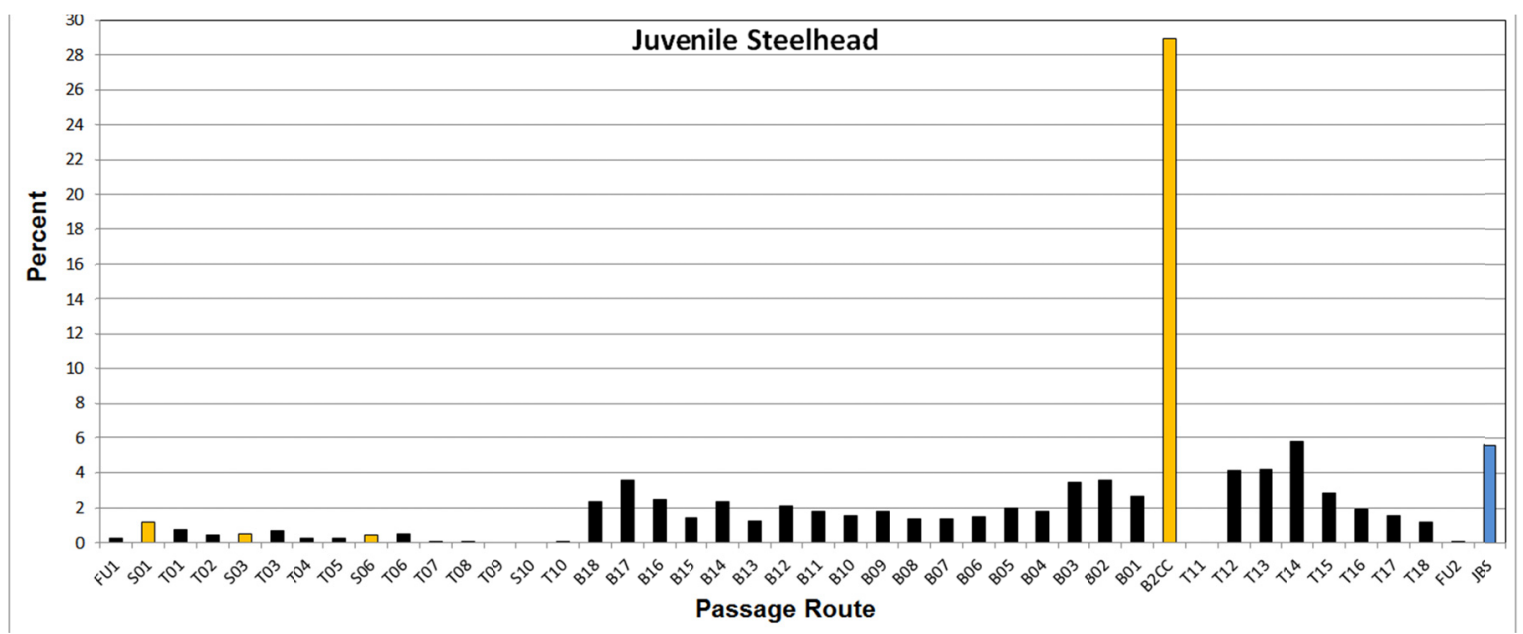

Figure 5.1. Horizontal Distribution of Juvenile Steelhead Passage in Spring 2010. Percent passage through surface-flow outlets (S01, S03, S06, S10, and the B2CC) are shown as gold bars, and $\mathrm{B} 1$ outlets are displayed to the left of the adjacent turbine with the same number, although they are actually physically located above the adjacent turbines. Abbreviations are as follows FU = fish units; S01, S03, S06, S10 = B1 sluiceway outlets; T1-T10= $\mathrm{B} 1$ turbines; $\mathrm{B} 01-\mathrm{B} 18=$ spill bays; $\mathrm{B} 2 \mathrm{CC}=\mathrm{B} 2$ Corner Collector; $\mathrm{T} 11-\mathrm{T} 18=\mathrm{B} 2$ turbines; $\mathrm{JBS}=\mathrm{B} 2$ juvenile bypass system. 


\subsection{Effect of the B2 Behavioral Guidance System}

There was insufficient power to reliably detect significant differences with available sample sizes, but the mean B2CC passage efficiency for juvenile steelhead was $67.1 \%$ for the pre BGS years and $58.1 \%$ for the post BGS years, a decrease of $9.1 \%$ (Table 5.4). The percent of turbine-passed juvenile STH increased 5.5\% from an average of $14.6 \%$ in 2004-2005 studies to an average of $20.1 \%$ in 2008-2010 studies (Table 5.4).

Table 5.4. Passage Percentage for Tagged Juvenile Steelhead Migrating Downstream Through B2CC and B2 Turbine Routes. Data from 2004 and 2005 are from USGS radio-telemetry studies (Counihan et al. 2006a and b, respectively), and data from 2008, 2009, and 2010 are from the PNNL acoustic-telemetry studies (Faber et al. 2010, 2011; and this study, respectively).

\begin{tabular}{cccc}
\hline Year & B2CC & Turbine & BGS \\
\hline 2004 & 73.0 & 16.7 & none \\
2005 & 67.1 & 12.4 & none \\
2008 & 75.0 & 16.0 & installed \\
2009 & 59.0 & 27.0 & installed \\
2010 & 57.1 & 17.2 & installed \\
\hline
\end{tabular}




\subsection{Results - Subyearling Chinook Salmon}

This section contains estimates of survival rates, travel times, passage efficiencies, and passage distributions for $\mathrm{CH} 0$ at $\mathrm{BON}$ during summer 2010. Appendices to this report include related tagging and release data (Appendix A), hydrophone location data (Appendix B), capture history data (Appendix C), detection and survival probabilities (Appendix D), and an assessment of model assumptions (Appendix E).

The single-release design worked as conceived for CH0. Performance of the JSATS technology was good. The combined detection probability of the two independent dam-face arrays, based on a Lincoln Peterson index, exceeded $99 \%$ for every route, and detection probabilities of autonomous arrays were $>0.85$ for dam $+81 \mathrm{~km}$ of tailwater and forebay + dam $+81 \mathrm{~km}$ of tailwater-passage survival estimates, (Appendix D, Tables D.17 and D.18). The survival model assumptions were met. The distribution of $\mathrm{CH} 0$ salmon lengths selected for tagging was shifted slightly (about $7 \mathrm{~mm}$ ) to the right of the distribution for fish in SMF samples because no fish $<95 \mathrm{~mm}$ were tagged (Figure E.2). The median length of tagged subyearlings was $6.5 \mathrm{~mm}$ longer than that of untagged fish passing through the JDA SMF. The length distributions for the $\mathrm{CHO}$ among releases were quite similar, and the median length of tagged fish across the course of the study remained stable (Skalski et al. 2010b). Tagging mortality was only $0.22 \%$, and no acoustic tags were shed between the time of tagging and the time of release. Travel times were sufficiently short relative to tag life to adequately adjust the release-recapture data for tag failure (Figure E.7). For dam-passage survival estimates, the probability that an acoustic tag was active at a downstream detection location was $>0.99$ (Table E.3). Study implementation produced near-perfect balance for the $\mathrm{CH0}$ (Table E.6). Auxiliary analyses found no tagger effects (Table E.9) that might confound estimation of dam-passage survival. A separate release of 67 dead fish with active tags into the $\mathrm{B} 2 \mathrm{CC}$ in summer 2010 resulted in no downstream detections at rkm 153, 113, or 86. Downstream mixing of virtual release fish with reference release fish was not an issue because there were no reference releases of fish in the BON tailrace in 2010.

\subsection{Survival Estimates}

The single-release estimate of tag-life-adjusted dam passage for $\mathrm{CH} 0 V_{1}$ traveling from the $\mathrm{BON}$ dam-face array CR234 to detection array CR153 was calculated to be

$$
\hat{S}_{\text {BON \& Tailwater }}=\hat{S}_{1}=0.958
$$

with an associated standard error of 0.0055 . The standard error was based on both the multinomial sampling error of the release-recapture process and the sampling error associated with the estimation of the probabilities of tag activation. The single-release estimate of dam-passage survival for $\mathrm{CH} 0$ at $\mathrm{BON}$ in 2010 was based only on a virtual release of tagged fish released in TDA and near Hood River, Oregon $(\mathrm{n}=1443)$. This point estimate exceeded the $2008 \mathrm{BiOp}$ standard of 0.930 , and the standard error was less than the BiOP requirement ( $\widehat{\mathrm{SE}}$ was $\leq 0.015$ ). Fish released near Roosevelt, Oregon, were not included in the virtual release because BON virtual release survival of those fish $(0.933 ; \widehat{\mathrm{SE}}=0.0058 ; n=$ 2033) was significantly lower than that of those released downstream of TDA, based on non-overlap of 95\% confidence intervals (Figure 6.1). Nevertheless, the virtual release survival of Roosevelt-released 
subyearlings also met the $2008 \mathrm{BiOp}$ standard (point estimate $\geq 0.930$ and $\widehat{\mathrm{SE}} \leq 0.015$ ). The $95 \%$ confidence intervals on day and night virtual release estimates of survival overlapped, and this suggests that day-night differences in virtual single-release survival were not significant.

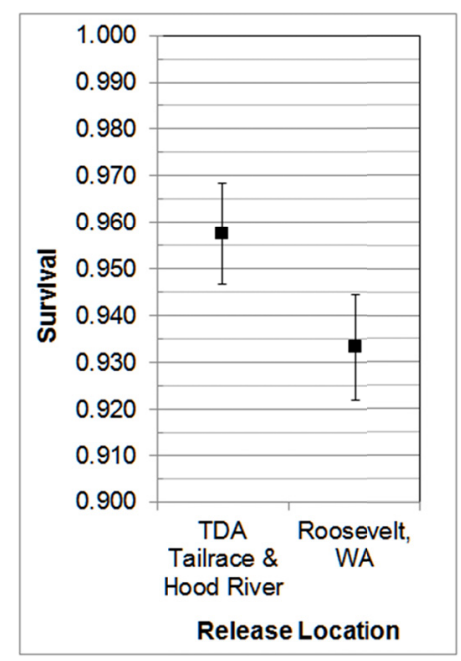

Figure 6.1. Plot of Virtual Single-Release Survival Estimates and 95\% Confidence Intervals for Subyearlings Released in The Dalles Tailrace and Near Hood River, Oregon Compared to an Estimate for Fish Released Near Roosevelt, Washington

We calculated a paired-release estimate of dam-passage survival by dividing the single-release estimate (above) by an estimate of B2CC-passage survival and that quotient met the BiOp standard, as did its standard error:

$$
\frac{\hat{S}_{1}}{\hat{S}_{B 2 C C}}=\frac{0.958}{0.970}=0.9870 ; \quad \text { Paired release } \widehat{\mathrm{SE}}=0.0117
$$

An estimate of forebay-to-tailrace passage survival could not be calculated because there were no tailrace reference releases in 2010, so we calculated a single-release estimate of passage survival for subyearlings passing $2 \mathrm{~km}$ of forebay, the dam, and $81 \mathrm{~km}$ of tailwater:

$$
\hat{S}_{\text {forebay, dam, tailwater }}=0.956(\widehat{\mathrm{SE}}=0.0054) \text {. }
$$

This estimate was 0.0021 lower than the single-release estimate for passage through the dam and $81 \mathrm{~km}$ of tailwater, and presumably this difference represents mortality attributable to passage through $2 \mathrm{~km}$ of forebay. The virtual single-release estimate for subyearlings passing through $2 \mathrm{~km}$ of forebay, the dam, and $81 \mathrm{~km}$ of tailwater also was based on fish released in The Dalles tailrace and near Hood River, Oregon $(\mathrm{n}=1571)$.

From highest to lowest, the rank of route-specific, virtual single-release estimates of dam-passage survival for subyearlings was as follows: B2 JBS (97.6\%), B2CC (97.0\%), B1 turbines (96.7, B1 sluiceway (94.3\%), B2 turbines (93.6\%), and spillway (93.0\%) (Table 6.1). Even the lowest routespecific single-release estimate met the $2008 \mathrm{BiOp}$ requirement. 
Table 6.1. Route-Specific Dam-Passage Survival Estimates for Subyearling Chinook Salmon

\begin{tabular}{clccc}
\hline Metric & \multicolumn{1}{c}{ Route } & Estimate & SE & $\mathrm{n}$ \\
\hline Dam-Passage Survival & B2 JBS & 0.976 & 0.0154 & 113 \\
& B2CC & 0.970 & 0.0101 & 311 \\
& B1 turbines & 0.967 & 0.0081 & 568 \\
& B1 sluiceway & 0.943 & 0.0173 & 196 \\
& B2 turbines & 0.936 & 0.0117 & 437 \\
& Spillway & 0.930 & 0.0062 & 1787 \\
\hline
\end{tabular}

\subsection{Travel Times}

Statistical estimates of travel times were based on fish in all releases upstream of BON (Table 6.2), because we did not see obvious travel-time differences for subyearlings in the Roosevelt release and those released downstream of TDA. The median forebay residence time for subyearlings was only $6.7 \%$ slower than estimates for $\mathrm{CH} 1$, but $41 \%$ slower than estimates for STH. Trends were similar for median project passage times. The median egress time was faster than the forebay residence time, but this was true for all three runs of fish.

Table 6.2. Travel Times (h) for Subyearling Chinook Salmon

\begin{tabular}{lrccc}
\hline \multicolumn{1}{c}{ Metric } & \multicolumn{1}{c}{$\mathrm{n}$} & Median & Mean & SE \\
\hline Forebay Residence (CR236 to CR234) & 3444 & 0.6933 & 1.1444 & 0.0421 \\
100-m Forebay Residence & 761 & 0.1331 & 1.0004 & 0.1640 \\
Tailrace Egress (CR234 to CR233) & 2993 & 0.4192 & 1.4454 & 0.2587 \\
Project Passage (CR236 to CR233) & 3233 & 1.2597 & 2.5804 & 0.2447 \\
\hline
\end{tabular}

\subsection{Passage Efficiencies}

Statistical estimates of passage efficiencies were based on fish in all releases upstream of BON (Table 6.3), because we did not observe obvious differences for subyearlings in the Roosevelt release and those released downstream of TDA. Day and night differences had the potential to be confounded by spill treatments, so we estimated passage metrics by day or night and spill treatment. Significant differences are based on the non-overlap of $95 \%$ confidence intervals.

Under the 24-h, 95-kcfs spill treatment, FPE was 21.4\% higher during daytime than it was at night on an absolute basis, and 95\% confidence intervals on those estimates did not overlap (Table 6.3). Similarly, estimates of SPE, spill + B2CC passage efficiency, B2CC passage efficiency relative to B2 and the dam, and B1 sluiceway efficiency relative to the dam all were higher during the day than they were at night under 24-h, $95 \mathrm{kcfs}$ spill, based on non-overlap of $95 \%$ confidence intervals. 
Table 6.3. Passage Efficiencies for Subyearling Chinook Salmon

\begin{tabular}{|c|c|c|c|c|}
\hline Metric & Period & Estimate & SE & $\mathrm{n}$ \\
\hline \multirow[t]{5}{*}{ FPE } & Overall & 0.705 & 0.0078 & 3412 \\
\hline & 95 kcfs day & 0.816 & 0.0158 & 604 \\
\hline & $95 \mathrm{kcfs}$ night & 0.602 & 0.0296 & 274 \\
\hline & $85 \mathrm{kcfs}$ day & 0.747 & 0.0187 & 541 \\
\hline & $120 \mathrm{kcfs}$ night & 0.746 & 0.0331 & 173 \\
\hline \multirow[t]{5}{*}{ Spill-Passage Efficiency } & Overall & 0.524 & 0.0086 & 3412 \\
\hline & 95 kcfs day & 0.632 & 0.0196 & 604 \\
\hline & $95 \mathrm{kcfs}$ night & 0.423 & 0.0298 & 274 \\
\hline & $85 \mathrm{kcfs}$ day & 0.514 & 0.0215 & 541 \\
\hline & $120 \mathrm{kcfs}$ night & 0.595 & 0.0373 & 173 \\
\hline \multirow[t]{5}{*}{ Spill+B2CC Passage Efficiency } & Overall & 0.615 & 0.0083 & 3412 \\
\hline & 95 kcfs day & 0.780 & 0.0169 & 604 \\
\hline & 95 kcfs night & 0.471 & 0.0302 & 274 \\
\hline & $85 \mathrm{kcfs}$ day & 0.669 & 0.0202 & 541 \\
\hline & $120 \mathrm{kcfs}$ night & 0.642 & 0.0365 & 173 \\
\hline \multirow[t]{5}{*}{ B1 Sluiceway $\|$ B1 = B1 FPE } & Overall & 0.257 & 0.0158 & 764 \\
\hline & $95 \mathrm{kcfs}$ day & 0.258 & 0.0786 & 31 \\
\hline & 95 kcfs night & 0.453 & 0.0684 & 53 \\
\hline & 85 kcfs day & 0.247 & 0.0468 & 85 \\
\hline & $120 \mathrm{kcfs}$ night & 0.421 & 0.1133 & 19 \\
\hline \multirow[t]{5}{*}{ B1 Sluiceway || Dam } & Overall & 0.057 & 0.0040 & 3412 \\
\hline & $95 \mathrm{kcfs}$ day & 0.013 & 0.0047 & 604 \\
\hline & $95 \mathrm{kcfs}$ night & 0.088 & 0.0171 & 274 \\
\hline & $85 \mathrm{kcfs}$ day & 0.039 & 0.0083 & 541 \\
\hline & $120 \mathrm{kcfs}$ night & 0.046 & 0.0160 & 173 \\
\hline \multirow[t]{5}{*}{$\mathrm{B} 2 \mathrm{CC} \| \mathrm{B} 2$} & Overall & 0.361 & 0.0164 & 861 \\
\hline & $95 \mathrm{kcfs}$ day & 0.466 & 0.0361 & 191 \\
\hline & $95 \mathrm{kcfs}$ night & 0.124 & 0.0321 & 105 \\
\hline & $85 \mathrm{kcfs}$ day & 0.472 & 0.0374 & 178 \\
\hline & $120 \mathrm{kcfs}$ night & 0.157 & 0.0509 & 51 \\
\hline \multirow[t]{5}{*}{ B2CC $\|$ Dam } & Overall & 0.091 & 0.0049 & 3412 \\
\hline & $95 \mathrm{kcfs}$ day & 0.147 & 0.0144 & 604 \\
\hline & $95 \mathrm{kcfs}$ night & 0.047 & 0.0128 & 274 \\
\hline & $85 \mathrm{kcfs}$ day & 0.155 & 0.0156 & 541 \\
\hline & $120 \mathrm{kcfs}$ night & 0.046 & 0.0160 & 173 \\
\hline \multirow[t]{5}{*}{ B2 FGE } & Overall & 0.205 & 0.0172 & 550 \\
\hline & $95 \mathrm{kcfs}$ day & 0.137 & 0.0341 & 102 \\
\hline & $95 \mathrm{kcfs}$ night & 0.130 & 0.0351 & 92 \\
\hline & $85 \mathrm{kcfs}$ day & 0.223 & 0.0430 & 94 \\
\hline & $120 \mathrm{kcfs}$ night & 0.233 & 0.0644 & 43 \\
\hline \multirow[t]{5}{*}{ B2 JBS || Dam } & Overall & 0.033 & 0.0031 & 3412 \\
\hline & $95 \mathrm{kcfs}$ day & 0.023 & 0.0061 & 604 \\
\hline & $95 \mathrm{kcfs}$ night & 0.044 & 0.0124 & 274 \\
\hline & $85 \mathrm{kcfs}$ day & 0.039 & 0.0083 & 541 \\
\hline & $120 \mathrm{kcfs}$ night & 0.058 & 0.0177 & 173 \\
\hline
\end{tabular}


During the daytime, 95-kcfs spill treatment produced higher FPE, SPE, spill + B2CC passage efficiency, and B1 sluiceway efficiency relative to the dam than did the 85-kcfs spill treatment (Table 6.3). During the nighttime, the 120-kcfs spill treatment provided for higher FPE, SPE, and spill + B2CC passage efficiency than did the $95-\mathrm{kcfs}$ spill treatment. However, the $95-\mathrm{kcfs}$ day treatment provided higher FPE, spill+B2CC passage efficiency, and B2CC passage efficiency (relative to B2 or the entire dam) than did the 120-kcfs night treatment. The 85- kcfs day treatment also provided for higher B2CC passage efficiency for subyearlings (relative to B2 or the dam) than did the 120 - kcfs night treatment. The 85- kcfs day treatment provided for higher FPE, spill+B2CC passage efficiency, and B2CC passage efficiency (re: B2 and the dam) than did the 95- kcfs night treatment. There were no apparent differences in B2 JBS efficiency relative to the dam among spill treatment and day/night conditions (Table 6.3).

\subsection{Passage Distributions}

The distributions of all detection events on the four forebay entrance array nodes were relatively uniform. From the Oregon shore north toward Washington, the percent of all subyearling detections on the four nodes were $23 \%, 22 \%, 34 \%$, and $21 \%$. The distribution of passage at the three dam structures more closely followed the distribution of flow among the three structures than the distribution of detection events on the forebay array. The distribution of flow and fish passage through the dam was as follows: B1 passed $22 \%$ of subyearlings in $16 \%$ of project flow; the spillway passed $51 \%$ of subyearlings in $50 \%$ of river flow; B2 passed $27 \%$ of subyearlings in $34 \%$ of flow. Over $99 \%$ of subyearlings passed through the Bonneville project at the dam structure where they were first detected, and this was true during high spill (spill $\geq 35 \%=99.8 \%)$ and lower spill $(<35 \%=100 \%)$ levels.

A plot of the distribution of passage among individual routes through the dam clearly shows that more $\mathrm{CH} 0$ passed through the spillway and B2 than through B1 (Figure 6.2). This pattern is consistent with observations for $\mathrm{CH} 0$ and $\mathrm{CH} 1$. The plot also shows that surface-flow outlets passed a high percentage of fish at each powerhouse. Percent passage was slightly higher through end spill bays 2-3 and 16-17 than through most other bays. Percent passage through the JBS was similar to the percent passing through turbine 14, although it was higher than the percent passing other individual turbines. Turbine 11 was out of service all summer and turbine 13 only ran a couple of days during the summer study. 


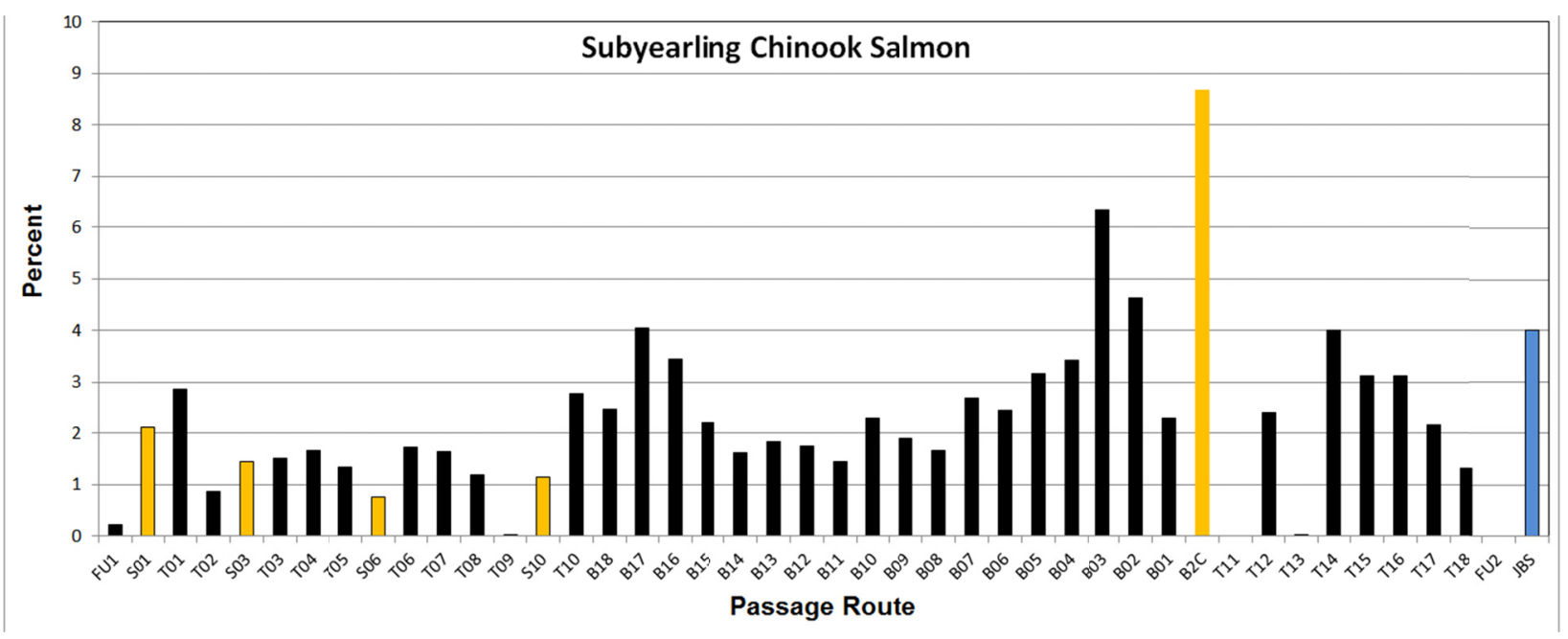

Figure 6.2. Horizontal Distribution of Subyearling Chinook Salmon Passage in Spring 2010. Percent passage through surface-flow outlets (S01, S03, S06, S10, and the B2CC) are shown as gold bars, and B1 outlets are displayed to the left of the adjacent turbine with the same number, although they are actually physically located above the adjacent turbines. Abbreviations are as follows FU = fish units; S01, S03, S06, S10 = B1 sluiceway outlets; T1-T10= $\mathrm{B} 1$ turbines; $\mathrm{B} 01-\mathrm{B} 18=$ spill bays; $\mathrm{B} 2 \mathrm{CC}=\mathrm{B} 2$ Corner Collector; $\mathrm{T} 11-\mathrm{T} 18=\mathrm{B} 2$ turbines; $\mathrm{JBS}=\mathrm{B} 2$ juvenile bypass system.

\subsection{Effect of the B2 Behavioral Guidance System}

There was insufficient statistical power to reliably detect significant differences given available sample sizes, but the mean B2CC passage efficiency for subyearlings was similar for the pre- and postBGS periods (Pre BGS averaged 44.9\% and Post BGS averaged 42.7\%; Table 6.4). The mean percent of turbine-passed subyearlings also was very similar for the two treatment periods (pre BGS averaged 41.2\% and post BGS averaged $40.8 \%$; Table 6.4 ).

Table 6.4. Passage Percentage for Tagged Subyearling Chinook Salmon Migrating Downstream Through B2CC and B2 Turbine Routes. Data from 2004 and 2005 are from USGS radiotelemetry studies (Counihan et al. 2006a and b, respectively), and data from 2008, 2009, and 2010 are from the PNNL acoustic-telemetry studies (Faber et al. 2010, 2011; and this study, respectively).

\begin{tabular}{cccc}
\hline Year & B2CC & Turbine & BGS \\
\hline 2004 & 43.4 & 43.3 & none \\
2005 & 46.4 & 39.0 & none \\
2008 & 40.0 & 43.0 & installed \\
2009 & 52.0 & 36.0 & installed \\
2010 & 36.1 & 43.4 & Installed \\
\hline
\end{tabular}




\subsection{Effects of Spill Treatments on Performance Metrics}

We used virtual releases of all fish released upstream of BON (Roosevelt, The Dalles Tailrace, and Hood River) to evaluate the effects of the two spill treatments in summer 2010. Survival estimates by treatment date are listed in Table 6.5. A plot of these data shows a typical summer decline in survival after July 10 for both treatments, but pairs of treatments consistently had overlapping $95 \%$ confidence intervals (Figure 6.2). A paired, two-tailed t-test based on the point estimates of survival rates in Table 6.5 detected no significant difference between the treatments, but the statistical power of this test was very low (0.284). A one-tailed t-test on the same data was significant $(\mathrm{P}=0.0484 ; \alpha=0.05$;

Table 6.6), indicating that the $24-\mathrm{h}, 95-\mathrm{kcfs}$ spill treatment provided higher survival for subyearlings than the $85-\mathrm{kcfs}$ day and 120 -kcfs night treatment.

Table 6.5. Virtual Single-Release Dam-Passage Survival Estimates and 95\% Confidence Intervals (CIs) by Spill Treatment in Summer 2010

\begin{tabular}{|c|c|c|c|c|c|c|c|}
\hline \multirow[b]{2}{*}{ Date } & \multicolumn{3}{|c|}{ 24-h, 95-kcfs Spill } & \multirow[b]{2}{*}{ Date } & \multicolumn{3}{|c|}{ Day $85-$ and Night $120-\mathrm{kcfs}$ Spill } \\
\hline & Survival & $1 / 295 \% \mathrm{CI}$ & $\mathrm{n}$ & & Survival & $1 / 295 \% \mathrm{CI}$ & $\mathrm{n}$ \\
\hline $7 / 3$ & 0.945 & 0.0652 & 51 & $7 / 2$ & 0.952 & 0.0337 & 161 \\
\hline $7 / 4$ & 0.962 & 0.0307 & 154 & $7 / 5$ & 0.973 & 0.0386 & 71 \\
\hline $7 / 7$ & 0.966 & 0.0462 & 59 & $7 / 6$ & 0.929 & 0.0450 & 127 \\
\hline $7 / 8$ & 0.955 & 0.0335 & 152 & $7 / 9$ & 0.960 & 0.0457 & 73 \\
\hline $7 / 10$ & 0.947 & 0.0368 & 147 & $7 / 11$ & 0.853 & 0.0842 & 68 \\
\hline $7 / 12$ & 0.914 & 0.0548 & 109 & $7 / 13$ & 0.842 & 0.0791 & 82 \\
\hline $7 / 14$ & 0.851 & 0.0640 & 120 & $7 / 15$ & 0.713 & 0.1297 & 48 \\
\hline $7 / 16 \& 19$ & 0.866 & 0.0657 & 104 & $7 / 17 \& 18$ & 0.875 & 0.0662 & 194 \\
\hline Mean & 0.923 & & 845 & Mean & 0.887 & & 824 \\
\hline
\end{tabular}

We observed no significant differences in travel time and passage efficiency metrics between the two spill treatments, as prescribed in the study design, based on overlap of $95 \%$ confidence intervals

(Table 6.7). We did find differences in some passage efficiency metrics among combinations of spill and day/night conditions (see Section 6.3 above), but significant differences were not observed for survival rates or travel times. 


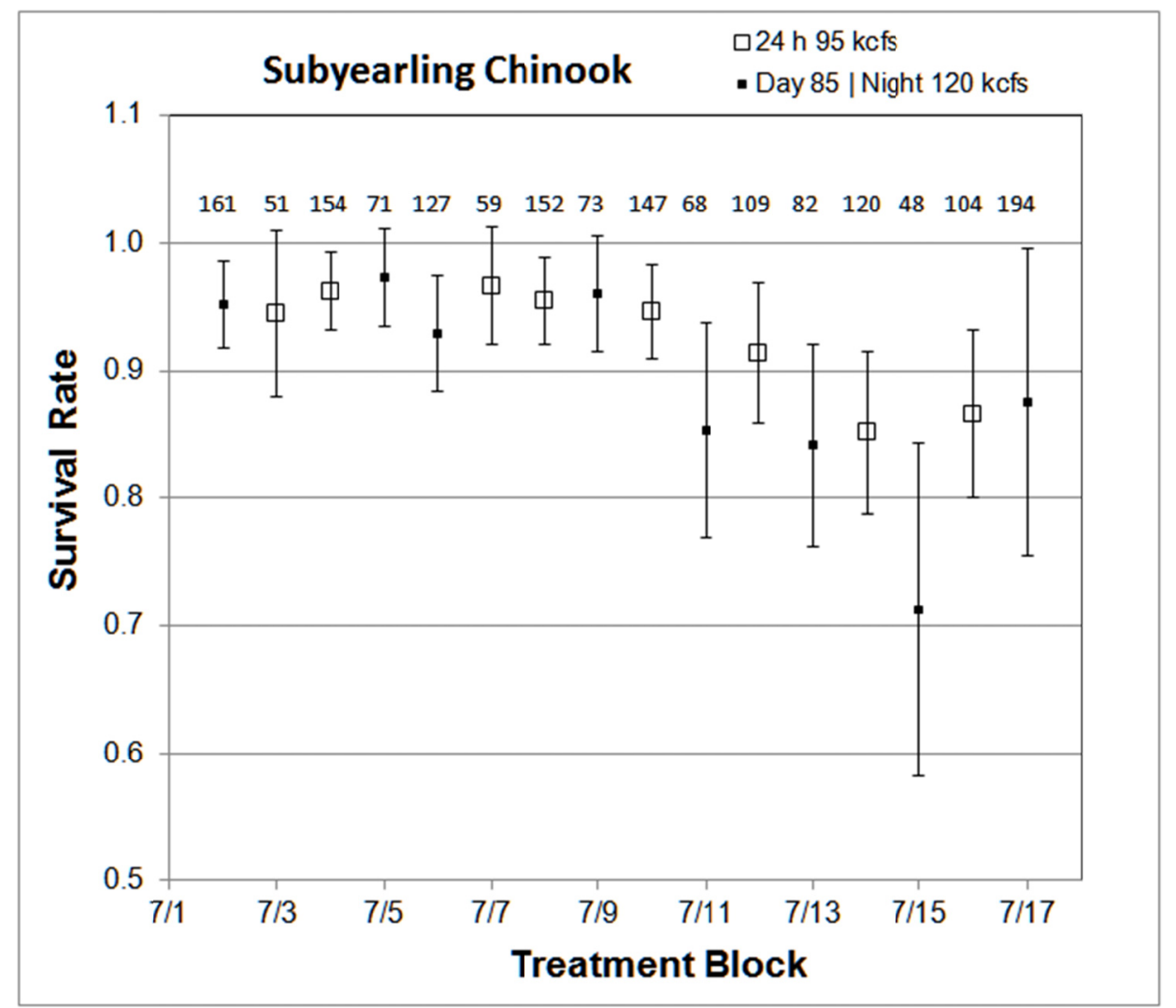

Figure 6.3. Plot of Subyearling Chinook Salmon Survival Rates by Spill Treatment Date. Estimates for the last two spill treatments $(n=104$ and $n=194)$ were based on pooling fish by treatment from blocks 8 and 9 .

Table 6.6. Statistical Tests on Subyearling Chinook Salmon Survival by Spill Treatment. The table includes one- and two-tailed t-test results for data in Table 6.5. Those data passed a normality test and a test on variance equality.

\begin{tabular}{lcc}
\hline \multicolumn{1}{c}{ Statistics } & 24-h 95-kcfs Spill & $\begin{array}{c}\text { Day 85- and } \\
\text { Night 120-kcfs Spill }\end{array}$ \\
\hline Mean & 0.9256 & 0.8870 \\
Variance & 0.0020 & 0.0075 \\
Observations & 8 & 8 \\
Pearson Correlation & 0.8062 & \\
Hypothesized Mean Difference & 0 & \\
df & 7 & \\
t Stat & 1.9161 & \\
$\mathrm{P}(\mathrm{T} \leq \mathrm{t})$ one-tail & 0.0484 & \\
t Critical one-tail & 1.8946 & \\
$\mathrm{P}(\mathrm{T} \leq \mathrm{t})$ two-tail & 0.0969 & \\
$\mathrm{t}$ Critical two-tail & 2.3646 & \\
\hline
\end{tabular}


Table 6.7. Comparison of Subyearling Chinook Salmon Travel Time and Passage Metrics Under the Two Summer Spill Treatments. Differences indicated in the last column were not considered to be different if there was overlap in $1 / 295 \%$ confidence intervals $(1.96 \times \widehat{\mathrm{SE}})$ for the two estimates.

\begin{tabular}{|c|c|c|c|c|c|c|c|}
\hline Metric & $\begin{array}{c}95 \mathrm{kcfs} \\
\text { Spill } \\
7 / 2-7 / 18\end{array}$ & $\widehat{\mathrm{SE}}$ & $\mathrm{n}$ & $\begin{array}{c}85 \mathrm{D} / 120 \mathrm{~N} \\
\text { kcfs Spill } \\
7 / 2-7 / 18\end{array}$ & $\widehat{\mathrm{SE}}$ & $\mathrm{n}$ & Different? \\
\hline Median Forebay Residence Time (CR236 to CR234) & 0.795 & 0.0617 & 884 & 0.943 & 0.1671 & 720 & No \\
\hline Median 100-m Forebay Residence Time (100 m to CR234) & 0.271 & 0.2671 & 120 & 0.471 & 0.9137 & 124 & No \\
\hline $\begin{array}{l}\text { Median Egress Time (dam to end of tailrace; CR234 to } \\
\text { CR233) }\end{array}$ & 0.483 & 0.0890 & 851 & 0.482 & 0.0643 & 678 & No \\
\hline Median Project Passage Time (CR236 to CR233) & 1.371 & 0.1101 & 861 & 1.533 & 0.1888 & 684 & No \\
\hline FPE \| Dam & 0.749 & 0.0146 & 878 & 0.747 & 0.0163 & 714 & No \\
\hline Spill Passage Efficiency || Dam & 0.567 & 0.0167 & 878 & 0.534 & 0.0187 & 714 & No \\
\hline Spill + B2CC Passage Efficiency $\|$ Dam & 0.683 & 0.0157 & 878 & 0.662 & 0.0177 & 714 & No \\
\hline B1 Sluiceway Passage Efficiency || B1 & 0.381 & 0.0530 & 84 & 0.279 & 0.0440 & 104 & No \\
\hline B2CC Passage Efficiency \| B2 & 0.345 & 0.0276 & 296 & 0.402 & 0.0324 & 229 & No \\
\hline B2 JBS Passage Efficiency || B2 & 0.088 & 0.0165 & 296 & 0.135 & 0.0226 & 229 & No \\
\hline B2 FGE (B2 Screen Efficiency) $\|$ (B2 turbine + B2 JBS) & 0.134 & 0.0245 & 194 & 0.226 & 0.0357 & 137 & No \\
\hline B2 FPE $\|$ B2 & 0.432 & 0.0288 & 296 & 0.537 & 0.0330 & 229 & No \\
\hline B1 Sluiceway Passage Efficiency || Dam & 0.036 & 0.0063 & 878 & 0.041 & 0.0074 & 714 & No \\
\hline B2CC Passage Efficiency \| Dam & 0.116 & 0.0108 & 878 & 0.129 & 0.0125 & 714 & No \\
\hline B2 JBS Passage Efficiency $\|$ Dam & 0.030 & 0.0057 & 878 & 0.043 & 0.0076 & 714 & No \\
\hline
\end{tabular}




\subsection{Discussion}

This section includes discussion of the statistical performance and survival model assumptions, historical context for 2010 estimates, day and night effects on passage metrics, effects of spillway discharge treatments in summer, and the performance of the B2 behavioral guidance structure in 2010.

\subsection{Statistical Performance and Survival Model Assumptions}

The survival study at BON in 2010 was not an official BiOp test because there were no tailrace and tailwater reference releases of fish as called for in the design by Skalski et al. (2010). Among other objectives, the 2010 study at BON was intended to verify that the proposed acoustic-tag monitoring system at the dam and downstream arrays would be adequate for an official BiOp study in 2011. For each run of fish in the 2010 study, we calculated a paired virtual-release survival estimate based on the ratio of virtual single-release survival rates of fish passing the dam and fish passing through the B2CC. This is not exactly the same as the virtual/paired-release design, but it did provide estimates of precision that were higher than estimates from the single-release model and similar in magnitude to those expected from the virtual/paired-release design.

The $2008 \mathrm{BiOp}$ requires estimates of dam-passage survival with standard errors $\leq 0.015$. The numbers of tagged fish released (Table 2.1; Appendix A) and the detection probabilities at the downstream autonomous node arrays (Appendix D, Sections D.1.1, D.2.1, D.3.1) in 2010 were sufficient to meet this precision requirement. Even when we calculated standard errors for paired-release dampassage survival estimates using B2CC-passed fish as a virtual reference release, standard errors were $\leq 0.007$ for $\mathrm{CH} 1$ and $\mathrm{STH}$ and $<0.012$ for $\mathrm{CH} 0$. Therefore, the number of tagged fish released for the survival studies in future years should be comparable to those used in 2010 to help ensure precision requirements will be achieved. If autonomous node densities in downstream survival detection arrays are changed or river discharge increases substantially, the number of fish tagged may need to be reassessed.

Testing of survival model assumptions (Appendix E) indicated that there were no serious violations that would invalidate the 2010 results. Length frequency distributions of tagged fish and the untagged fish passing through the JDA SMF were very similar for CH1 and juvenile STH. The 95-mm length limit imposed by acoustic-tag weight and acceptable tag burdens for small fish resulted in a slightly high grading of fish lengths for $\mathrm{CH} 0$, as indicated by a $6.5-\mathrm{mm}$ difference in median lengths of tagged and untagged fish. Post-tagging and pre-release mortality was low (CH1: $0.1 \%$, STH: $0.05 \%$; CH0: $0.22 \%$ ), and no acoustic tags were shed. In 2010, the study team released 97 dead fish with active acoustic tags into the $\mathrm{B} 2 \mathrm{CC}$, and none of these fish were detected on survival detection arrays located 81, 121, and $148 \mathrm{~km}$ downstream from the dam. Tag life was more than adequate for the survival study, and the probability of a tag being active when fish passed the downstream survival detection arrays exceeded $99 \%$. There were no observed tagger effects in 2010. Downstream mixing was not an assumption for the virtual single-release survival model. It also was not an issue for paired-release estimates based on the survival of fish passing through the dam and the $\mathrm{B} 2 \mathrm{CC}$, because fish in both of these virtual releases passed the dam during all hours of the day and B2CC-passed fish were a subset of dam-passed fish. 


\subsection{Historical Context}

The following sections compare historical estimates of survival rates, travel time, and passage efficiency with estimates in this report.

\subsubsection{Survival Estimates}

We provide context for 2010 dam-passage survival estimates by tabling them with estimates from previous studies. Before 2008, there was no BGS installed in the B2 forebay like there was from 2008 through 2010. The USGS conducted paired-release survival studies at B2 using radio telemetry in 2002, 2004, and 2005, which included dam passage of fish passing through the JBS, B2CC, and turbines (Counihan et al. 2003; Counihan et al. 2006a, b).

We visually looked for obvious non-overlap of $1 / 295 \%$ confidence intervals to judge whether $\mathrm{CH} 1$ survival estimates in Table 7.1 differed among years. For this exercise, estimates $>1$ were set to 1.0 so that obvious positive bias in point estimates would be eliminated. By these criteria, there were no significant differences in dam-passage survival among years. Survival rates of B1-passed yearlings were lower in 2002 and 2004 than they were in 2010, but estimates for 2002, 2004, and 2005 did not differ. Spillway survival rates appeared to be higher in 2002 than they were in 2004 and 2005, and the point estimate in 2010 was 3.4\% lower than the 2002 estimate, although confidence intervals for 2002 and 2010 overlapped slightly. Survival of B2-, B2CC-, B2 JBS-, and B2 turbine-passed yearlings did not differ among years. Survival of B2CC passed fish was very high in all years and the multi-year average would rank it as the best route of passage through the dam for yearlings. Survival estimates for yearlings passing through B2 turbines was surprisingly high (grand mean $=0.967$ ). A ranking of general routes and subroutes from highest to lowest according to the grand average survival rate (Table 7.1) was as follows: B2CC, JBS, B2, turbines, B1, and the spillway.

We visually looked for obvious non-overlapping of $1 / 295 \%$ confidence intervals to judge whether juvenile STH survival estimates in Table 7.2 differed among years. For this exercise, estimates $>1$ were set to 1.0 so that obvious positive bias in point estimates would be eliminated. Using these criteria, none of the passage survival rates in Table 7.2 differed significantly, except for the 2005 and 2008 turbinepassage estimates. We ranked routes from best to worst for STH according to the grand mean survival rate as follows: B2CC, JBS, B2, spillway or B1 (tied), and turbines.

For $\mathrm{CH} 0$, we again looked for obvious non-overlapping of $1 / 295 \%$ confidence intervals to judge whether survival estimates in Table 7.3 differed among years. For this exercise, estimates $>1$ were again set to 1.0 so that obvious positive bias in point estimates would be eliminated. Using these criteria, dampassage survival was higher in 2008 and 2010 than it was in 2004 and 2005, and the 2005 estimate was higher than the 2004 estimate. The confidence interval in 2009 was wide and overlapped intervals for all other dam-passage survival estimates. The B1-passage survival was higher in 2010 than it was in 2004, but the estimates in 2005 and 2010 were similar. The 2010 spill-passage survival rate was higher than rates in 2004 and 2005. Estimates of B2-, B2CC-, and JBS-passage survival did not differ among study years. Turbine-passage survival was higher in 2008, 2009, and 2010 than it was in 2004 and 2005. We ranked routes from best to worst for subyearlings according to the grand mean survival rate as follows: B2CC, JBS, B2, B1, turbines, and the spillway. 
Table 7.1. Survival of Yearling Chinook Salmon that Passed Through Various Routes at Bonneville Dam in Some Years from 2002 Through 2010. Numbers in parentheses are $1 / 2$ 95\% confidence limits. Unless otherwise indicated, estimates were derived from paired-release CJS recapture models that used control releases of fish in the tailrace of BON. Data from 2002 to 2005 were reported from radio-telemetry studies conducted by the USGS, and 2008 and 2009 data are from acoustic-telemetry studies conducted by PNNL.

\begin{tabular}{|c|c|c|c|c|c|c|c|}
\hline Year & $\mathrm{B} 1$ & Spillway & B2 & $\mathrm{B} 2 \mathrm{CC}$ & JBS & Turbines & Dam \\
\hline 2002 & $\begin{array}{c}0.902 \\
(0.063)\end{array}$ & $\begin{array}{c}0.977 \\
(0.023)\end{array}$ & $\begin{array}{c}0.993 \\
(0.028)\end{array}$ & & & & $\begin{array}{c}0.977 \\
(0.038)\end{array}$ \\
\hline 2004 & $\begin{array}{c}0.913 \\
(0.041)\end{array}$ & $\begin{array}{c}0.910 \\
(0.021)\end{array}$ & $\begin{array}{c}0.979 \\
(0.029)^{(\mathrm{a})}\end{array}$ & $\begin{array}{l}1.016 \\
(0.017)\end{array}$ & $\begin{array}{c}0.970 \\
(0.024)\end{array}$ & $\begin{array}{c}0.951 \\
(0.021)\end{array}$ & $\begin{array}{c}0.951 \\
(0.015)\end{array}$ \\
\hline 2005 & $\begin{array}{c}0.950 \\
(0.031)\end{array}$ & $\begin{array}{c}0.913 \\
(0.035)\end{array}$ & $\begin{array}{c}0.998 \\
(0.015)^{(\mathrm{a})}\end{array}$ & $\begin{array}{l}1.021 \\
(0.012)\end{array}$ & $\begin{array}{l}1.008 \\
(0.016)\end{array}$ & $\begin{array}{c}0.966 \\
(0.017)\end{array}$ & $\begin{array}{c}0.966 \\
(0.013)\end{array}$ \\
\hline 2008 & & & $\begin{array}{c}1.005 \\
(0.030)\end{array}$ & $\begin{array}{l}1.021 \\
(0.034)\end{array}$ & $\begin{array}{l}1.017 \\
(0.045)\end{array}$ & $\begin{array}{c}0.979 \\
(0.037)\end{array}$ & $\begin{array}{c}0.969 \\
(0.025)\end{array}$ \\
\hline 2009 & \multicolumn{2}{|c|}{$0.952(0.014)^{(b, c)}$} & $\begin{array}{c}0.986 \\
(0.008)^{(\mathrm{c})}\end{array}$ & $\begin{array}{c}0.996 \\
(0.004)^{(\mathrm{d})}\end{array}$ & $\begin{array}{c}0.988 \\
(0.013)^{(\mathrm{c})}\end{array}$ & $\begin{array}{c}0.970 \\
(0.020)^{(\mathrm{c})}\end{array}$ & $\begin{array}{c}0.962 \\
(0.011)^{(\mathrm{c})}\end{array}$ \\
\hline 2010 & $\begin{array}{c}0.994 \\
(0.026)^{(\mathfrak{c})}\end{array}$ & $\begin{array}{c}0.943 \\
(0.015)^{(\mathrm{c})}\end{array}$ & $\begin{array}{c}0.985 \\
(0.013)^{(\mathfrak{c})}\end{array}$ & $\begin{array}{c}0.991 \\
(0.009)^{(\mathrm{d})}\end{array}$ & $\begin{array}{c}0.990 \\
(0.023)^{(\mathrm{c})}\end{array}$ & $\begin{array}{c}0.971 \\
(0.018)^{(\mathrm{c})}\end{array}$ & $\begin{array}{c}0.961 \\
(0.012)^{(\mathrm{c})}\end{array}$ \\
\hline $\begin{array}{l}\text { Grand } \\
\text { Average }\end{array}$ & 0.940 & 0.936 & 0.991 & 1.009 & 0.9946 & 0.967 & 0.970 \\
\hline
\end{tabular}

(a) Calculated as an average of rates for B2 routes.

(b) B1 and spillway combined estimate.

(c) Relative release estimate, using fish passing through the $\mathrm{B} 2 \mathrm{CC}$ as the paired control fish.

(d) Single-release estimate.

Table 7.2. Survival of Juvenile Steelhead that Passed Through Various Routes at Bonneville Dam in Some Years from 2004 Through 2010. Numbers in parentheses are $1 / 295 \%$ confidence limits. Unless otherwise indicated, estimates were derived from paired-release CJS recapture models that used control releases of fish in the tailrace of BON. Data from 2002 to 2005 were reported from radio-telemetry studies conducted by the USGS, and 2008 and 2009 data are from acoustic-telemetry studies conducted by PNNL.

\begin{tabular}{|c|c|c|c|c|c|c|c|}
\hline Year & $\mathrm{B} 1$ & Spillway & $\mathrm{B} 2$ & $\mathrm{~B} 2 \mathrm{CC}$ & JBS & Turbines & Dam \\
\hline 2004 & $\begin{array}{c}0.965 \\
(0.034)\end{array}$ & $\begin{array}{c}0.979 \\
(0.023)\end{array}$ & $\begin{array}{c}0.956 \\
(0.042)^{(a)}\end{array}$ & $\begin{array}{c}1.030 \\
(0.017)\end{array}$ & $\begin{array}{c}0.951 \\
(0.024)\end{array}$ & $\begin{array}{c}0.889 \\
(0.038)\end{array}$ & $\begin{array}{c}0.991 \\
(0.016)\end{array}$ \\
\hline 2005 & $\begin{array}{c}0.933 \\
(0.030)\end{array}$ & $\begin{array}{c}0.955 \\
(0.021)\end{array}$ & $\begin{array}{c}0.944 \\
(0.027)^{(\mathrm{a})}\end{array}$ & $\begin{array}{c}1.009 \\
(0.012)\end{array}$ & $\begin{array}{c}0.956 \\
(0.016)\end{array}$ & $\begin{array}{c}0.868 \\
(0.035)\end{array}$ & $\begin{array}{c}0.963 \\
(0.013)\end{array}$ \\
\hline 2008 & & & $\begin{array}{c}0.982 \\
(0.019)\end{array}$ & $\begin{array}{c}0.984 \\
(0.027)\end{array}$ & $\begin{array}{c}0.984 \\
(0.045)\end{array}$ & $\begin{array}{c}0.982 \\
(0.024)\end{array}$ & $\begin{array}{c}0.972 \\
(0.010)\end{array}$ \\
\hline 2009 & \multicolumn{2}{|c|}{$0.961(0.021)^{(\mathrm{b}, \mathrm{c})}$} & $\begin{array}{c}0.979 \\
(0.026)^{(\mathrm{c})}\end{array}$ & $\begin{array}{c}0.993 \\
(0.020)^{(\mathrm{d})}\end{array}$ & $\begin{array}{c}0.964 \\
(0.013)^{(\mathrm{c})}\end{array}$ & $\begin{array}{c}0.946 \\
(0.054)^{(\mathrm{c})}\end{array}$ & $\begin{array}{c}0.970 \\
(0.013)^{(\mathrm{c})}\end{array}$ \\
\hline 2010 & $\begin{array}{c}0.950 \\
(0.042)\end{array}$ & $\begin{array}{c}0.963 \\
(0.017)\end{array}$ & $\begin{array}{c}0.979 \\
(0.015)\end{array}$ & $\begin{array}{c}0.975 \\
(0.011)\end{array}$ & $\begin{array}{c}1.003 \\
(0.025)\end{array}$ & $\begin{array}{c}0.933 \\
(0.025)\end{array}$ & $\begin{array}{c}0.969 \\
(0.014)\end{array}$ \\
\hline $\begin{array}{c}\text { Grand } \\
\text { Average }\end{array}$ & 0.952 & 0.952 & 0.968 & 0.998 & 0.972 & 0.924 & 0.973 \\
\hline
\end{tabular}

(a) Calculated as an average of rates for B2 routes.

(b) B1 and spillway combined estimate.

(c) Relative release estimate, using fish passing through the $\mathrm{B} 2 \mathrm{CC}$ as the paired control fish.

(d) Single-release estimate. 
Table 7.3. Survival of Subyearling Chinook Salmon that Passed Through Various Routes at Bonneville Dam in Some Years from 2004 Through 2010. Numbers in parentheses are $1 / 2$ 95\% confidence limits. Unless otherwise indicated, estimates were derived from paired-release CJS recapture models that used control releases of fish in the tailrace of BON. Data from 2002 to 2005 were reported from radio-telemetry studies conducted by the USGS, and 2008 and 2009 data are from acoustic-telemetry studies conducted by PNNL.

\begin{tabular}{cccccccc}
\hline Year & B1 & Spillway & B2 & B2CC & JBS & Turbines & Dam \\
\hline \multirow{2}{*}{2004} & 0.831 & 0.876 & 0.904 & 0.980 & 0.926 & 0.825 & 0.891 \\
& $(0.110)$ & $(0.025)$ & $(0.060)^{(\mathrm{a})}$ & $(0.023)$ & $(0.048)$ & $(0.037)$ & $(0.020)$ \\
\multirow{2}{*}{2005} & 0.976 & 0.911 & 0.964 & 1.013 & 0.984 & 0.895 & 0.938 \\
& $(0.072)$ & $(0.018)$ & $(0.026)^{(\mathrm{a})}$ & $(0.015)$ & $(0.028)$ & $(0.028)$ & $(0.014)$ \\
2008 & & & 0.981 & 0.996 & 0.991 & 0.954 & 0.970 \\
& & & $(0.016)$ & $(0.016)$ & $(0.024)$ & $(0.020)$ & $(0.014)$ \\
2009 & \multirow{2}{*}{$0.930(0.062)^{(\mathrm{b}, \mathrm{c})}$} & 0.991 & 0.942 & 0.933 & 0.998 & 0.959 \\
& & $(0.063)^{(\mathrm{c})}$ & $(0.054)^{(\mathrm{d})}$ & $(0.087)^{(\mathrm{c})}$ & $(0.079)^{(\mathrm{c})}$ & $(0.063)^{(\mathrm{c})}$ \\
2010 & 0.990 & 0.959 & 0.983 & 0.970 & 1.006 & 0.965 & 0.987 \\
Grand & $(0.025)$ & $(0.023)$ & $(0.025)$ & $(0.020)$ & $(0.037)$ & $(0.031)$ & $(0.023)$ \\
Average & 0.929 & 0.915 & 0.965 & 0.978 & 0.968 & 0.927 & 0.949 \\
\hline
\end{tabular}

(a) Calculated as an average of rates for B2 routes.

(b) B1 and spillway combined estimate.

(c) Relative release estimate, using fish passing through the $\mathrm{B} 2 \mathrm{CC}$ as the paired control fish.

(d) Single-release estimate.

The ranking of routes in 2010 varied among the runs of fish studied, but it is important to note that the spillway ranked as the worst route for passing $\mathrm{CH} 1$ and $\mathrm{CH} 0$ smolts (see Tables 7.1 and 7.3). For juvenile STH, the spillway ranked fourth after the B2 JBS, B2CC, and B1 sluiceway, but the spill-passage survival rate of 0.939 for STH was only slightly better than rates observed for $\mathrm{CH} 1(0.935)$ and $\mathrm{CH} 0$ (0.930) passing the spillway. The turbines at B1 and B2 clearly were the worst routes for passing STH, probably because injury associated with blade strike is directly correlated with fish length (Ploskey and Carlson 2004; Deng et al. 2007, 2011b). The median length of tagged juvenile STH (214 mm) was considerably longer than that of $\mathrm{CH} 1(152 \mathrm{~mm})$ and $\mathrm{CHO}(110 \mathrm{~mm})$ smolts.

Survival of fish passing through the B1 sluiceway was high in spring $(\mathrm{CH} 1=0.980 ; \mathrm{STH}=0.963)$, but in summer, B1 sluiceway-passage survival of subyearlings was only $0.943,2.4 \%$ lower than the rate for subyearlings passing through B1 turbines. The reason for lower B1 sluiceway survival in summer might be related to debris loading on the B1 sluiceway route because the hydrograph clearly peaked in summer (Figure 3.1). The shallow openings in the B1 surface-flow outlets are more prone to clogging than the B2CC outlet, which provided high survival in both seasons.

\subsubsection{Travel Time Estimates}

Forebay residence times were longer for STH than for Chinook salmon smolts, and this was not a surprise given the extensive searching behavior exhibited by STH in the B2 forebay. A full 12\% of STH passed the project at a dam structure other than the one at which they were first detected. Out of the 1,638 STH that first approached the spillway, 313 (19.1\%) subsequently passed at one of the 
powerhouses. In contrast, only $2.2 \%(n=39)$ of STH that approached either B1 $(n=202)$ or B2 $(n=$ 1569) passed at another dam structure. The median 100-m forebay residence time also was very short for Chinook salmon smolts $(0.133-0.178 \mathrm{~h})$ compared with that of STH(1.426 h).

The 100-m forebay residence time can be a misleading metric because the number of fish that can be tracked from $100 \mathrm{~m}$ upstream from the dam to the dam face is higher for quiet forebay areas such as B1 than it is in noisy areas such as the spillway. Historically, forebay residence times were calculated for each dam structure at Bonneville as the time from first detection by radio telemetry (presumably about $100 \mathrm{~m}$ from antennas) until the time of passage through the dam. Historical average estimates summarized by Ploskey et al. (2007a) for juvenile STH were $5.4 \mathrm{~h}$ for B1, 0.3 for the spillway and $3.0 \mathrm{~h}$ for B2. The average of those mean estimates for juvenile steelhead was $2.9 \mathrm{~h}$, and this was $48 \%$ of the mean estimate of $6.1 \mathrm{~h}$ in this study. About $40 \%$ of the STH in the 2010 sample were detected in the B1 forebay, which was acoustically very quiet relative to the spillway and somewhat quieter than the B2 forebay. The high proportion of STH from B1 likely biased the 2010 average 100-m residence time estimate high because flow through B1 was less than flow through the spillway or B2. The median travel time for STH in 2010 was $1.43 \mathrm{~h}$ and this was slightly lower than the historical average residence time for STH passing B2 and the spillway $(1.65 \mathrm{~h})$. Estimates of forebay residence summarized by Ploskey et al. (2007a) for CH1 were $2.2 \mathrm{~h}$ for B1, 0.2 for the spillway, and 0.5 for B2. The average of those mean estimates $(0.97 \mathrm{~h})$ was about $52 \%$ of the 2010 estimate for yearlings $(1.87 \mathrm{~h})$, which likely was biased high by having $43 \%$ of the sample from the B1 forebay, where the range of acoustic detection was high but forebay flow through the B1 powerhouse was low. The median forebay residence time for yearlings was just $0.17 \mathrm{~h}$ in 2010, and this was lower than the average historical estimate for yearlings passing B2 and the spillway. For $\mathrm{CH} 0$ smolts, average estimates of forebay residence times summarized by Ploskey et al. (2007a), were $4.4 \mathrm{~h}$ at B1, $0.4 \mathrm{~h}$ at the spillway, and $0.2 \mathrm{~h}$ at B2. The average of the historical means for the three locations $(1.67 \mathrm{~h}$ ) was reasonably close to the mean estimate for the dam in summer 2010 $(1.57 \mathrm{~h})$. The median $100-\mathrm{m}$ forebay residence time for subyearlings was just $0.133 \mathrm{~h}$. We prefer the use of median forebay residence times instead of means because they are less susceptible to bias by fish readily detected in quiet areas with low flow to carry fish to passage through the dam. Unfortunately, we could not find median estimates of forebay residence times to compare with 2010 estimates.

Holmberg et al. (2001) estimated median tailrace egress times for STH and CH1 and CH0. The estimated median egress times from the forebay to the B2 outfall vicinity for juvenile STH that passed B1 was $0.41 \mathrm{~h}$ and for STH passing the spillway it was $0.43 \mathrm{~h}$, and those historical egress times were reasonably close to our median estimate of $0.414 \mathrm{~h}$ for STH in 2010. Their estimate of median egress times from the forebay to the B2 outfall vicinity for $\mathrm{CH} 1$ that passed $\mathrm{B} 1$ was $0.49 \mathrm{~h}$ and for yearlings passing the spillway it was $0.41 \mathrm{~h}$. Those historical estimates were reasonably close to our median estimate of $0.455 \mathrm{~h}$ for yearlings in spring 2010. Their estimated median egress times from the forebay to the B2 outfall vicinity for subyearling Chinook that passed B1 was $0.40 \mathrm{~h}$ and for those subyearlings passing the spillway it was $0.41 \mathrm{~h}$. Those historical egress times were close to our median estimate of $0.42 \mathrm{~h}$ for subyearlings in summer 2010 .

Historical estimates of project passage time were not directly available from previous studies so we had no historical estimates to compare with 2010 estimates. 


\subsubsection{Passage-Efficiency Estimates}

Passage-efficiency metrics for each run of fish studied in 2010 were compared to available historical estimates as summarized by Ploskey et al. (2007a; Table 7.4). Most metrics were within the range of historical estimates, and those that were not within that range usually were off by only a few percentage points. For example, FPE estimates for STH and $\mathrm{CH} 0$ were within range, but FPE for $\mathrm{CH} 1$ was about $4.4 \%$ higher than the historical range. Other 2010 estimates that were slightly outside of their historical range were as follows: B1 sluiceway efficiency relative to B1 for subyearlings $(-3.3 \%$ below historical minimum), B2CC efficiency relative to $\mathrm{B} 2(\mathrm{STH}=-1.9 \%$; subyearlings $=-0.3 \%)$, and $\mathrm{B} 2 \mathrm{FGE}(\mathrm{STH}=$ $-8.3 \%, \mathrm{CH} 1=-4 \%$, and subyearlings $=-1.5 \%$ ).

Table 7.4. Comparison of Passage-Efficiency Metric Estimates in 2010 Relative to Available Historical Ranges for Non-Drought Years

\begin{tabular}{lcccccc}
\hline \multicolumn{1}{c}{ Metric (Percent) } & \multicolumn{2}{c}{$\begin{array}{c}\text { Historical } \\
\text { Range }^{(\mathrm{b})}\end{array}$} & $\mathrm{CH1}^{(\mathrm{a})}$ & $\begin{array}{c}\text { Historical } \\
\text { Range }^{(\mathrm{b})}\end{array}$ & $\mathrm{CH0}^{(\mathrm{a})}$ & $\begin{array}{c}\text { Historical } \\
\text { Range }^{(\mathrm{b})}\end{array}$ \\
\hline Fish-Passage Efficiency (FPE) || Dam & 79.5 & $78-86$ & 80.2 & $71-76$ & 70.5 & $68-90$ \\
Spill-Passage Efficiency (SPE) || Dam & 40.6 & $26-55$ & 52.8 & $33-57$ & 52.4 & $35-65$ \\
Spill + B2CC Passage Efficiency || Dam & 71.2 & & 71.7 & & 61.5 & \\
B1 Sluiceway Passage Efficiency || B1 (B1 FPE) & 40.8 & $29-65$ & 33.0 & $29-53$ & 25.7 & $29-59$ \\
B2CC Passage Efficiency || B2 & 57.10 & $59-75$ & 45.8 & $29-49$ & $36.1^{(\mathrm{c})}$ & $37-40$ \\
B2 Fish-Guidance Efficiency || JBS+Turbine & 25.7 & $34-59$ & 29 & $33-46$ & 20.5 & $22-47$ \\
B1 Sluiceway Passage Efficiency || Dam & 2.4 & & 1.9 & & 5.7 & \\
B2CC Passage Efficiency || Dam & 30.6 & & 19.0 & & 9.1 & \\
B2 JBS Passage Efficiency || Dam & 5.9 & & 6.5 & & 3.3 & \\
\hline
\end{tabular}

(a) $\mathrm{STH}=$ juvenile steelhead; $\mathrm{CH} 1=$ yearling Chinook salmon; $\mathrm{CH} 0=$ subyearling Chinook salmon.

(b) Non-drought years except for B2 FGE.

(c) Unit 11 out of service all year and Unit 13 operated only a few hours.

There was no backsliding on SPE in 2010. Historical estimates of SPE for non-drought spring periods ranged from 0.26 to 0.55 for juvenile $\mathrm{STH}$ and from 0.33 to 0.57 for $\mathrm{CH} 1$ (summarized by Ploskey et al. 2007a). The spring 2010 estimate of SPE was 0.406 for STH and 0.528 for CH1, and both of these estimates fall within the respective historical ranges for non-drought years. Historical estimates of subyearling SPE for non-drought summers ranged from 0.35 to 0.65 (summarized by Ploskey et al. 2007a). The 2010 estimate of SPE for subyearlings (0.524) is near the middle of the historical range for subyearlings in non-drought years.

\subsection{Day and Night Effects on Passage Metrics}

We found significant differences in some passage metrics related to day and night passage in spring or to combinations of day and night and spill condition in summer that could have important management implications. For CH1 smolts (Table 4.3), we observed that FPE, spill + B2CC passage efficiency, and $\mathrm{B} 2 \mathrm{CC}$ passage efficiency relative to $\mathrm{B} 2$ or the entire dam, and B2 JBS efficiency were all higher during the day than they were at night. The biggest difference was for in $\mathrm{CH} 1 \mathrm{~B} 2 \mathrm{FPE}$, which was $25.1 \%$ higher during the day $(70.7 \%)$ than it was at night (45.7\%). The CH1 B2CC-passage efficiency was $21.6 \%$ 
higher during the day than it was at night. For juvenile STH (Table 5.3), several metrics were higher during the day than they were at night, including $\mathrm{B} 2 \mathrm{CC}$ passage efficiency relative to $\mathrm{B} 2(+33.1 \%)$ or relative to the dam $(+31 \%)$, B1 sluiceway passage efficiency relative to B1 $(+32.1 \%)$, B2 FPE $(+28.5 \%)$, FPE $(+10.8 \%)$, and spillway + B2CC passage efficiency $(+9.7 \%)$. It is interesting to note that daytime periods had $9.7 \%$ higher spillway $+\mathrm{B} 2 \mathrm{CC}$ passage efficiency than nighttime periods in spite of the fact that spillway passage efficiency was $21.4 \%$ lower during the day than it was at night. For $\mathrm{CH} 0$ under the 95-kcfs spill treatment, daytime estimates were higher than nighttime estimates of FPE $(+21.4 \%)$, spill passage efficiency $(+20.9 \%)$, spill + B2CC passage efficiency $(30.9 \%)$, B2CC passage efficiency relative to $\mathrm{B} 2$ and the dam $(+34.2 \%)$, and $\mathrm{B} 2 \mathrm{CC}$ passage efficiency relative to the dam $(+10 \%)$. The passage efficiency of the B1 sluiceway relative to the entire dam was the only metric that actually was lower during the day than at night, and that was an artifact of most B1 turbines being shut down at night to accommodate $120-\mathrm{kcfs}$ spill treatments. The B1 sluiceway becomes the only option when B1 turbine operations are severely curtailed.

Fixed-aspect hydroacoustic and especially acoustic camera sampling of smolts passing into the B2CC and B1 sluiceway previously revealed that more smolts actively enter these surface-flow outlets during the day than enter at night (Ploskey et al. 2005, 2006). Sampling with a dual frequency identification sonar at the B1 sluiceway outlet above turbine 3 in 2005 clearly indicated that most smolts hold position upstream of the sluiceway outlet at night, where they are routinely attacked by piscivores. During the daytime, smolts were recorded actively passing into the sluiceway in schools and piscivore attacks were less common during the day than they were at night.

\subsection{Effect of Spillway Discharge Treatments in Summer}

We could not detect a significant difference between the two prescribed spill treatments tested in 2010 by comparing pooled survival estimates and associated $95 \%$ confidence intervals or by comparing similar measures for other fish passage metrics. The seasonal decline in subyearling survival was common to both spill treatments, and pairs of treatments in statistical blocks consistently had overlapping 95\% confidence intervals (see Figure 6.2).

The summer treatment study called for 16 blocks of paired spill treatments, with a randomized order of treatments within blocks. Unfortunately, river discharge overwhelmed dam operators' ability to provide prescribed spill treatments during the first half of the summer study between June 16 and July 1 (see Figure 3.3), and nine out of 16 pairs of 1-day treatments were realized, but the 24-h, 95-kcfs treatment in the ninth block only had six fish in it, so we pooled fish from the same treatments in blocks 8 and 9. Formal statistical tests lacked power to detect significant differences in survival, although a onetailed t-test on data in Table 6.5 was significant $(\mathrm{P}=0.0484 ; \alpha=0.05$; Table 6.3$)$. This result suggested that the 24-h, 95-kcfs spill treatment provided higher mean survival for subyearlings than did the $85-\mathrm{kcfs}$ day and $120-\mathrm{kcfs}$ night treatment. However, the calculated mean for the $85-\mathrm{kcfs}$ day and $120-\mathrm{kcfs}$ night treatment $(0.887$ ) was biased low by one point estimate on July 15 (survival $=0.713 ; \mathrm{n}=48$ ) relative to the seasonal pooled estimate for the same treatment (0.903), and this bias suggest that this test result is not reliable. The July 15 sample size for 48 fish was the smallest for any block and treatment. 


\subsection{Performance of the B2 Behavior Guidance Structure}

If successful, the behavioral guidance structure in the B2 forebay should have substantially increased yearling B2CC passage efficiency and reduced the percentage passing through turbines in 2008, 2009, and 2010 over passage rates observed in 2004 and 2005 before the BGS was installed. Any increase in B2 JBS passage proportions would be a bonus.

The B2 BGS showed some benefit for $\mathrm{CH} 1$ by increasing $\mathrm{B} 2 \mathrm{CC}$ passage efficiency by about $12.5 \%$, but a similar benefit was not obvious for juvenile STH and CH0. The survival of B2- and B2CC-passed fish of the three runs studied did not differ between pre- and post-BGS years. Having turbine 11, which is adjacent to the $\mathrm{B} 2 \mathrm{CC}$, out of service in spring and summer reduced the strength of lateral surface flows toward the south along the face of the powerhouse toward the $\mathrm{B} 2 \mathrm{CC}$ and may have adversely affected B2CC passage efficiency in 2010. In summer, turbine 13 ran only a few hours, and the combined loss of turbines 11 and 13 resulted in an atypical horizontal passage distribution that was much higher through the north turbine than through the south turbines. When all B2 turbines are running, fish passage typically is higher through turbines 11-14 than through turbines 15-18 (Ploskey et al. 2007a), and that skew is believed to be responsible for good $\mathrm{B} 2 \mathrm{CC}$ passage performance. 


\subsection{Conclusions and Recommendations}

The JSATS deployed at BON performed well and appears to be ready for an official BiOp test in 2011. The B2 BGS showed some benefit for CH1 by increasing B2CC passage efficiency by about $12.5 \%$, but such benefit was not obvious for juvenile STH and $\mathrm{CH} 0$. We could not detect a significant difference between the two spill treatments tested in 2010 by comparing pooled survival estimates or fishpassage metrics and their associated $95 \%$ confidence intervals for $\mathrm{CH} 0$. Point estimates of survival for pairs of treatment days within blocks consistently had overlapping $1 / 295 \%$ confidence intervals. Formal statistical tests on eight pairs of survival rates lacked power to detect significant differences, but the 24-h, $95-\mathrm{kcfs}$ point estimate was $2 \%$ higher than the point estimate under the $85-\mathrm{kcfs}$ day and $120-\mathrm{kcfs}$ night spill treatment.

Recommendations derived from the 2010 BON study are as follows:

1. Proceed with an official BiOp and Fish Accord compliance test in 2011. The JSATS acoustics monitoring system appears to be ready barring unforeseen circumstances.

2. Based on preliminary results of the 2010 study, we recommend that the Portland District remove the BGS from the B2 forebay before the 2011 study. We also recommended that the Portland District try to have turbines 11-14 in operation for any future compliance tests, because those units seem to be important for setting up forebay circulation that enhances B2CC passage efficiency.

3. We believe that the USACE should deploy focused stadium lighting at strategic locations within about $100 \mathrm{~m}$ of surface-flow outlets at B1 and B2. This could start with a temporary test deployment to determine whether the light deployment could successfully change the nighttime holding behavior of smolts upstream of surface-flow outlets, so that smolts would readily enter surface-flow outlets from the forebays like they do during the daytime. Many fish-passage metrics and especially those related to surface-flow outlets were significantly higher during the day than they were at night (see Section 7.3). In addition, previous acoustic camera studies at BON surface-flow outlets indicate clear differences in smolt behavior and the frequency of piscivore predator attacks during day and night periods (also in Section 7.3). If test light deployments are successful in changing smolt passage behavior at night, permanent light deployments should be designed and installed.

4. Debris clogging surface-flow outlets in the B1 forebay should be cleared as soon as possible, particularly in in summer when river discharge typically peaks each year. Survival of fish passing through the B1 sluiceway was high in spring $(\mathrm{CH} 1=0.980 ; \mathrm{STH}=0.963)$, but in summer, B1 sluiceway-passage survival of subyearlings was only $0.943,2.4 \%$ lower than the rate for subyearlings passing through B1 turbines. The shallow openings in the B1 surface-flow outlets are more prone to clogging in summer than is the $\mathrm{B} 2 \mathrm{CC}$ outlet, which provides for relatively high passage survival in spring and summer.

5. We recommend operating the project to avoid any further increase in the number or percent of fish passing through the spillway, until the underlying cause for its poor fish-passage survival performance is understood. We observed that point estimates of spill-passage survival were lower than point estimates for any other route used by $\mathrm{CH} 1$ and $\mathrm{CH} 0$. For $\mathrm{STH}$ smolts, the point estimate (0.935) was only higher than survival estimates for fish passing through B1 and B2 turbines (0.911 and 0.900, respectively). For STH smolts, spill-passage survival (0.939) was lower than passage survival for the B2 JBS (0.978), B2CC (0.975), and the B1 sluiceway (0.963). The 85-kcfs day and 120 -kcfs night spill treatment in summer produced a point estimate of virtual release survival that was 
$2.3 \%$ lower than the point estimate for the $24-\mathrm{h}, 95-\mathrm{kcfs}$ spill treatment. Given the apparent risk to subyearlings passing the spillway under the $85-\mathrm{kcfs}$ day and 120 - kcfs night treatment, we cannot in good conscience recommend further use of the latter treatment until the reason for poor spill-passage survival is understood.

6. The analysis of STH behavior in the forebay areas prior to passage (see Section 4.5 on passage distributions and discussion of travel time estimates in Section 7.2.2) made it clear that a lot of juvenile STH are rejecting the spillway as a passage route and passing through B1 or B2. If spillpassage survival could be improved, we would readily recommend installing two or three top spill weirs to reduce the spillway rejection rate for STH. However, STH that rejected the spillway in favor of B2 passage experienced $97.6 \%$ survival as opposed to $93.7 \%$ survival for STH passing through the spillway. 


\subsection{References}

3 Treaty Tribes-Action Agencies. 2008. Memorandum of Agreement Among the Umatilla, Warm Springs and Yakama Tribes, Bonneville Power Administration, U.S. Army Corps of Engineers, and U.S. Bureau of Reclamation, Portland, Oregon, April 4, 2008. Available at http://www.salmonrecovery.gov/Files/BiologicalOpinions/MOA_ROD.pdf.

Anglea S, T Poe, and A Giorgi. 2001. Synthesis of Radio Telemetry, Hydroacoustic, and Survival Studies of Juvenile Salmon at John Day Dam. PNWD-3117, report prepared for the U.S. Army Corps of Engineers, Portland District, by Battelle Pacific Northwest Division, Richland, Washington.

Beitinger TL and LC Fitzpatrick. 1979. "Physiological and ecological correlates of preferred temperature in fish." Am. Zool. 19:319-329.

Burnham KP, DR Anderson, GC White, C Brownie, and KH Pollock. 1987. "Design and Analysis Methods for Fish Survival Estimates Based on Release-recapture." American Fisheries Society Monograph 5.

Cash KM, DM Faber, TW Hatton, EC Jones, RJ Magie, NM Swyers, RK Burns, MD Sholtis, SA Zimmerman, JS Hughes, TL Gilbride, NS Adams, and DW Rondorf. 2005. Three-Dimensional Behavior and Passage of Juvenile Salmonids at The Dalles Dam, 2004. Final report for the U.S. Army Corps of Engineers, Portland, Oregon (Contract W66QKZ40278562), by the U.S. Geological Survey and Pacific Northwest National Laboratory, Richland, Washington.

Cormack RM. 1964. "Estimates of Survival from the Sightings of Marked Animals." Biometrika 51:429-438.

Counihan TD, GS Holmberg, and JH Petersen. 2003. Survival Estimates of Migrant Juvenile Salmonids through Bonneville Dam Using Radio-Telemetry, 2002. Annual report prepared for the U.S. Army Corps of Engineers, Portland District, Portland, Oregon, by the U.S. Geological Survey, Cook, Washington.

Counihan TD, AL Puls, CE Walker, JM Hardiman, and GS Holmberg. 2006a. Survival Estimates of Migrant Juvenile Salmonids through The Dalles Dam Using Radiotelemetry, 2004. Final Report of Research prepared by the U.S. Geological Survey, Cook, Washington, for the U.S. Army Corps of Engineers, Portland, Oregon.

Counihan TD, AL Puls, CE Walker, JM Hardiman, and GS Holmberg. 2006b. Survival Estimates of Migrant Juvenile Salmonids through The Dalles Dam Using Radiotelemetry, 2005. Final Report of Research prepared by the U.S. Geological Survey, Cook, Washington, for the U.S. Army Corps of Engineers, Portland, Oregon.

Deng ZD, MA Weiland, T Fu, TA Seim, BL LaMarche, EY Choi, TJ Carlson, and MB Eppard. 2011a. "A Cabled Acoustic Telemetry System for Detecting and Tracking Juvenile Salmon: Part 2. ThreeDimensional Tracking and Passage Outcomes." Sensors 11:5661-5676.

Deng Z, TJ Carlson, DD Dauble, and GR Ploskey. 2011b. "Fish Passage Assessment of an Advanced Hydropower Turbine and Conventional Turbine Using Blade-Strike Modeling." Energies 4(1):57-67. 
Deng Z, TJ Carlson, GR Ploskey, MC Richmond, and DD Dauble. 2007. "Evaluation of blade-strike models for estimating the biological performance of Kaplan turbines." Ecological Modeling 208:165-176.

Faber DM, MA Weiland, RA Moursund, TJ Carlson, N Adams, and D Rondorf. 2001. Evaluation of the Fish Passage Effectiveness of Bonneville I Prototype Surface Collector Using Three-Dimensional Ultrasonic Fish Tracking. PNNL-13526, Pacific Northwest National Laboratory, Richland, Washington.

Faber DM, GR Ploskey, MA Weiland, Z Deng, JS Hughes, RL McComas, J Kim, RL Townsend, T Fu, JR Skalski, and ES Fischer. 2010. Evaluation of a Behavioral Guidance Structure at Bonneville Dam Second Powerhouse including Passage Survival of Juvenile Salmon and Steelhead using Acoustic Telemetry, 2008. PNNL-18753, Pacific Northwest National Laboratory, Richland, Washington.

Faber, DM, GR Ploskey, MA Weiland, D Deng, JS Hughes, J Kim, T Fu, ES Fischer, TJ Monter, JS Skalski. 2011. Evaluation of Behavioral Guidance Structure on Juvenile Salmonid Passage and Survival at Bonneville Dam in 2009. PNNL 20338, Pacific Northwest National Laboratory Richland, Washington.

Giorgi AE and JR Stevenson. 1995. A Review of Biological Investigations Describing Smolt Passage Behavior at Portland District Corps of Engineers' Projects: Implications to Surface Collection Systems. Report prepared for the U.S. Army Corps of Engineers, Portland District by BioAnaysts, Inc., Redmond, Washington.

Hochachka P. 1990. "Scope for survival: A conceptual 'mirror' of Fry's scope for activity." Transactions of the American Fisheries Society 119:622-628.

Holmberg, GS, R E Wardell, MG Mesa, NS Adams, and DW Rondorf. 2001. Evaluation of the Bonneville Dam Second Powerhouse new Juvenile Bypass System, 1999. Annual Report by U.S. Geological Survey, Columbia River Research Laboratory, Cook, Washington for the U.S. Army Engineer District, Portland, Oregon.

Jolly GM. 1965. "Explicit estimates from capture-recapture data with both death and immigration Stochastic model." Biometrika 52:225-247.

Johnson G, J Beeman, I Duran, and A Puls. 2007. "Synthesis of Juvenile Salmonid Passage Studies at The Dalles Dam, Volume II: 2001-2005." PNNL-16443, final report submitted to the U.S. Army Corps of Engineers Portland District, by the Pacific Northwest National Laboratory, Richland, Washington, and the U.S. Geological Survey, Cook, Washington.

Kerr SR. 1990. “The Fry paradigm: Its significance for contemporary ecology.” Trans. Am. Fish. Soc. 1-119:779-785.

Kramer DL, RW Rangeley, and LJ Chapman. 1997. Habitat selection: Patterns of spatial distribution from behavioural decisions. In: Gaudin J-G (ed.). Behavioural Ecology of Teleost Fishes. Oxford University Press; Oxford, UK. pp. 37-79. 
Lady JM, P Westhagen, and JR Skalski. 2010. Program ATLAS 1: Active Tag Life Adjusted Survival. Columbia Basin Research, School of Aquatic and Fishery Sciences, University of Washington, Seattle, Washington.

Li T and JJ Anderson. 2009. "The vitality model: A way to understand population survival and demographic heterogeneity." Theoretical Population Biology 76(2):118-131.

Martinson R, G Kovalchuk, and D Ballinger. 2006. Monitoring of Downstream Salmon and Steelhead at Federal Hydroelectric Facilities, 2005-2006 Annual Report. Project No. 198712700, BPA Report DOE/BP-00022085-2, Bonneville Power Administration, Portland, Oregon.

McMichael GA, MB Eppard, TJ Carlson, JA Carter, BD Ebberts, RS Brown, M Weiland, GR Ploskey, RA Harnish, and Z Daniel Deng. 2010. "The Juvenile Salmon Acoustic Telemetry System: A New Tool." Fisheries 35(1):9-22.

NOAA (National Atmospheric and Oceanic Administration) Fisheries. 2008. Biological OpinionConsultation on Remand for Operation of the Federal Columbia River Power System, 11 Bureau of Reclamation Projects in the Columbia Basin and ESA Section 10(a)(1)(A) Permit for Juvenile Fish Transportation Program. National Marine Fisheries Service (NOAA Fisheries) - Northwest Region, Seattle, Washington. Available at: http://www.salmonrecovery.gov/.

Ploskey G, T Poe, A Giorgi, and G Johnson. 2001. Synthesis of Radio Telemetry, Hydroacoustic, and Survival Studies of Juvenile Salmon at The Dalles Dam (1982-2000). PNWD-3131, final report submitted to U.S. Army Corps of Engineers, Portland District, by Battelle Pacific Northwest Division, Richland, Washington.

Ploskey GR and TJ Carlson. 2004. Comparison of Blade-Strike Modeling Results with Empirical Data. Tech. Rep. PNNL-14603 to the U.S. Department of Energy Hydropower Program. 28 pp.

Ploskey GR, MA Weiland, CR Schilt, PN Johnson, ME Hanks, DS Patterson, JR Skalski, and J Hedgepeth. 2005. Hydroacoustic Evaluation of Fish Passage through Bonneville Dam in 2004. PNNL-15249, Pacific Northwest National Laboratory, Richland, Washington.

Ploskey GR, MA Weiland, SA Zimmerman, JS Hughes, K Bouchard, ES Fischer, CR Schilt, ME Hanks, J Kim, JR Skalski, J Hedgepeth, and WT Nagy. 2006. Hydroacoustic Evaluation of Fish Passage through Bonneville Dam in 2005. PNNL-15944, Pacific Northwest National Laboratory, Richland, Washington.

Ploskey GR, GE Johnson, AE Giorgi, RL Johnson, JR Stevenson, CR Schilt, PN Johnson, and DS Patterson. 2007a. Synthesis of Biological Reports on Juvenile Fish Passage and Survival at Bonneville Dam, 1939-2005. PNNL-15041, Pacific Northwest National Laboratory, Richland, Washington.

Ploskey GR, MA Weiland, JS Hughes, SA Zimmerman, RE Durham, ES Fischer, J Kim, RL Townsend, JR Skalski, and RL McComas. 2007b. Acoustic Telemetry Studies of Juvenile Chinook Salmon Survival at the Lower Columbia Projects in 2006. PNNL-16560, Pacific Northwest National Laboratory, Richland, Washington. 
Ploskey GR, MA Weiland, JS Hughes, SA Zimmerman, RE Durham, ES Fischer, J Kim, RL Townsend, JR Skalski, RA Buchanan, and RL McComas. 2008. Survival of Juvenile Chinook Salmon Passing the Bonneville Dam Spillway in 2007. PNNL-18113, prepared for the U.S. Army Corps of Engineer District, Portland, Oregon, by Pacific Northwest National Laboratory, Richland, Washington.

Ploskey GR, MA Weiland, DM Faber, Z Deng, GE Johnson, JS Hughes, SR Zimmerman, AW Cushing, MC Wilberding, RL Townsend, JR Skalski, J Kim, ES Fischer, MM Meyer, RL McComas, and JP Everett. 2009. Survival of Juvenile Salmonids Passing Bonneville Dam and Spillway in 2008. Draft Technical Report prepared for the U.S. Army Corps of Engineers, Portland District, by the Pacific Northwest National Laboratory, Richland, Washington.

Seber GAF. 1965. “A Note on the Multiple Recapture Census.” Biometrika 52:249-259.

Skalski JR. 2009. Statistical Design for the Lower Columbia River Acoustic-Tag Investigations of Dam Passage Survival and Associated Metrics. Study Design Document by the Columbia Basin Research School of Aquatic and Fishery Sciences, University of Washington, Seattle, for the U.S. Army Engineer District, Portland, Oregon.

Skalski JR, GE Johnson, and TJ Carlson. 2010a. Compliance Monitoring of Juvenile Yearling Chinook Salmon and Steelhead Survival and Passage at The Dalles Dam, Spring 2010. Summary Report PNNL-19819, Pacific Northwest National Laboratory, Richland, Washington.

Skalski JR, GE Johnson, and TJ Carlson. 2010b. Compliance Monitoring of Juvenile Subyearling Chinook Salmon Survival and Passage at The Dalles Dam, Summer 2010. Summary Report PNNL-20042, Pacific Northwest National Laboratory, Richland, Washington.

Townsend RL, JR Skalski, P Dillingham, and TW Steig. 2006. "Correcting Bias in Survival Estimation Resulting from Tag Failure in Acoustic and Radiotelemetry Studies.” Journal of Agricultural Biology and Environmental Statistics 11:183-196.

U.S. Army Corps of Engineers. 2011. Surgical Protocols for Implanting JSATS Transmitters into Juvenile Salmonids for Studies Conducted for the U. S. Army Corps of Engineers. Version 1.0. USACE, Portland District, Portland, Oregon.

Weiland MA, GR Ploskey, JS Hughes, Z Deng, T Fu, TJ Monter, GE Johnson, F Khan, MC Wilberding, AW Cushing, SA Zimmerman, DM Faber, RE Durham, RL Townsend, JR Skalski, J Kim, ES Fischer, and MM Meyer. 2009. Acoustic Telemetry Evaluation of Juvenile Salmonid Passage and Survival at John Day Dam with Emphasis on the Prototype Surface Flow Outlet, 2008. PNNL-18890, Pacific Northwest National Laboratory, Richland, Washington.

Weiland MA, GR Ploskey, JS Hughes, Z Deng, T Fu, JA Kim, GE Johnson, ES Fischer, F Khan, SA Zimmerman, DM Faber, KM Carter, JW Boyd, RL Townsend, JR Skalski, TJ Monter, AW Cushing, MC Wilberding, and MM Meyer. 2011a. Acoustic Telemetry Evaluation of Juvenile Salmonid Passage and Survival Proportions at John Day Dam, 2009. PNNL-20766, Pacific Northwest National Laboratory, Richland, Washington. 
Weiland MA, ZD Deng, TA Seim, BL LaMarche, EY Choi, T Fu, TJ Carlson, AI Thronas, and MB Eppard. 2011b. "A Cabled Acoustic Telemetry System for Detecting and Tracking Juvenile Salmon: Part 1. Engineering Design and Instrumentation.” Sensors 11:5645-5660.

Underwood AJ, MG Chapman, and SD Connell. 2000. "Observations in ecology: You can't make progress on processes without understanding the patterns." Journal of Experimental Marine Biology and Ecology 250:97-115. 
Appendix A

Fish-Tagging Tables 


\section{Appendix A}

\section{Fish-Tagging Tables}

Table A.1. 2010 Yearling Chinook Salmon Tagged at John Day Dam and Released Live at Three Sites

\begin{tabular}{|c|c|c|c|c|c|}
\hline Tag Date & Release Date & Number Tagged & Release Location & Number Released & Mortalities \\
\hline $4 / 27 / 2010$ & $4 / 28 / 2010$ & 72 & Roosevelt & 72 & \\
\hline $4 / 28 / 2010$ & $4 / 29 / 2010$ & 72 & Roosevelt & 72 & \\
\hline \multirow[t]{2}{*}{$4 / 29 / 2010$} & $4 / 30 / 2010$ & 97 & Roosevelt & 72 & \\
\hline & & & TDA tailrace & 25 & \\
\hline \multirow[t]{2}{*}{$4 / 30 / 2010$} & $5 / 1 / 2010$ & 97 & Roosevelt & 72 & \\
\hline & & & Hood River & 25 & \\
\hline \multirow[t]{3}{*}{$5 / 1 / 2010$} & $5 / 2 / 2010$ & 147 & Roosevelt & 72 & \\
\hline & & & TDA tailrace ${ }^{(a)}$ & 50 & \\
\hline & & & Hood River & 25 & \\
\hline \multirow[t]{2}{*}{$5 / 2 / 2010$} & $5 / 3 / 2010$ & 96 & Roosevelt & 72 & \\
\hline & & & Hood River & 24 & \\
\hline \multirow[t]{3}{*}{$5 / 3 / 2010$} & $5 / 4 / 2010$ & 147 & Roosevelt & 72 & \\
\hline & & & TDA tailrace ${ }^{(a)}$ & 49 & 1 \\
\hline & & & Hood River & 25 & \\
\hline \multirow[t]{2}{*}{$5 / 4 / 2010$} & $5 / 5 / 2010$ & 103 & Roosevelt & 72 & $5^{(\mathrm{b})}$ \\
\hline & & & Hood River & 26 & \\
\hline \multirow[t]{3}{*}{$5 / 5 / 2010$} & $5 / 6 / 2010$ & 147 & Roosevelt & 71 & 1 \\
\hline & & & TDA tailrace $^{(\mathrm{a})}$ & 50 & \\
\hline & & & Hood River & 25 & \\
\hline \multirow[t]{2}{*}{$5 / 6 / 2010$} & $5 / 7 / 2010$ & 97 & Roosevelt & 72 & \\
\hline & & & Hood River & 25 & \\
\hline \multirow[t]{3}{*}{$5 / 7 / 2010$} & $5 / 8 / 2010$ & 147 & Roosevelt & 71 & 1 \\
\hline & & & TDA tailrace $^{(a)}$ & 49 & 1 \\
\hline & & & Hood River & 25 & \\
\hline \multirow{2}{*}{$5 / 8 / 2010$} & $5 / 9 / 2010$ & 97 & Roosevelt & 72 & \\
\hline & & & Hood River & 25 & \\
\hline \multirow[t]{3}{*}{$5 / 9 / 2010$} & $5 / 10 / 2010$ & 148 & Roosevelt & 72 & $1^{(\mathrm{b})}$ \\
\hline & & & TDA tailrace ${ }^{(\mathrm{a})}$ & 50 & \\
\hline & & & Hood River & 25 & \\
\hline $5 / 10 / 2010$ & $5 / 11 / 2010$ & 23 & & & $23^{(\mathrm{b})}$ \\
\hline \multirow[t]{3}{*}{$5 / 11 / 2010$} & $5 / 12 / 2010$ & 147 & Roosevelt & 72 & \\
\hline & & & TDA tailrace ${ }^{(\mathrm{a})}$ & 50 & \\
\hline & & & Hood River & 25 & \\
\hline \multirow[t]{2}{*}{$5 / 12 / 2010$} & $5 / 13 / 2010$ & 194 & Roosevelt & 144 & \\
\hline & & & Hood River & 50 & \\
\hline \multirow[t]{3}{*}{$5 / 13 / 2010$} & $5 / 14 / 2010$ & 146 & Roosevelt & 72 & \\
\hline & & & TDA tailrace ${ }^{(a)}$ & 50 & \\
\hline & & & Hood River & 24 & \\
\hline
\end{tabular}


Table A.1. (contd)

\begin{tabular}{|c|c|c|c|c|c|}
\hline Tag Date & Release Date & Number Tagged & Release Location & Number Released & Mortalities \\
\hline \multirow[t]{2}{*}{$5 / 14 / 2010$} & $5 / 15 / 2010$ & 97 & Roosevelt & 72 & \\
\hline & & & Hood River & 25 & \\
\hline \multirow[t]{3}{*}{$5 / 15 / 2010$} & $5 / 16 / 2010$ & 147 & Roosevelt & 72 & \\
\hline & & & TDA tailrace ${ }^{(a)}$ & 50 & \\
\hline & & & Hood River & 25 & \\
\hline \multirow[t]{2}{*}{$5 / 16 / 2010$} & $5 / 17 / 2010$ & 97 & Roosevelt & 72 & \\
\hline & & & Hood River & 25 & \\
\hline \multirow[t]{3}{*}{$5 / 17 / 2010$} & $5 / 18 / 2010$ & 146 & Roosevelt & 72 & \\
\hline & & & TDA tailrace ${ }^{(\mathrm{a})}$ & 49 & \\
\hline & & & Hood River & 25 & \\
\hline \multirow[t]{2}{*}{$5 / 18 / 2010$} & $5 / 19 / 2010$ & 96 & Roosevelt & 71 & \\
\hline & & & Hood River & 25 & \\
\hline \multirow[t]{3}{*}{$5 / 19 / 2010$} & $5 / 20 / 2010$ & 147 & Roosevelt & 72 & \\
\hline & & & TDA tailrace ${ }^{(\mathrm{a})}$ & 50 & \\
\hline & & & Hood River & 25 & \\
\hline \multirow[t]{2}{*}{$5 / 20 / 2010$} & $5 / 21 / 2010$ & 97 & Roosevelt & 72 & \\
\hline & & & Hood River & 25 & \\
\hline \multirow[t]{3}{*}{$5 / 21 / 2010$} & $5 / 22 / 2010$ & 147 & Roosevelt & 72 & \\
\hline & & & TDA tailrace ${ }^{(\mathrm{a})}$ & 50 & \\
\hline & & & Hood River & 25 & \\
\hline \multirow[t]{2}{*}{$5 / 22 / 2010$} & $5 / 23 / 2010$ & 97 & Roosevelt & 72 & \\
\hline & & & Hood River & 25 & \\
\hline \multirow[t]{3}{*}{$5 / 23 / 2010$} & $5 / 24 / 2010$ & 147 & Roosevelt & 72 & \\
\hline & & & TDA tailrace ${ }^{(\mathrm{a})}$ & 50 & \\
\hline & & & Hood River & 25 & \\
\hline \multirow[t]{2}{*}{$5 / 24 / 2010$} & $5 / 25 / 2010$ & 97 & Roosevelt & 72 & \\
\hline & & & Hood River & 25 & \\
\hline \multirow[t]{3}{*}{$5 / 25 / 2010$} & $5 / 26 / 2010$ & 146 & Roosevelt & 71 & \\
\hline & & & TDA tailrace ${ }^{(\mathrm{a})}$ & 50 & \\
\hline & & & Hood River & 25 & \\
\hline \multirow[t]{2}{*}{$5 / 26 / 2010$} & $5 / 27 / 2010$ & 97 & Roosevelt & 72 & \\
\hline & & & Hood River & 25 & \\
\hline \multirow[t]{3}{*}{$5 / 27 / 2010$} & $5 / 28 / 2010$ & 147 & Roosevelt & 73 & \\
\hline & & & TDA tailrace ${ }^{(a)}$ & 50 & \\
\hline & & & Hood River & 24 & \\
\hline \multirow[t]{2}{*}{$5 / 28 / 2010$} & $5 / 29 / 2010$ & 83 & Roosevelt & 58 & \\
\hline & & & Hood River & 25 & \\
\hline \multirow[t]{2}{*}{$5 / 29 / 2010$} & $5 / 30 / 2010$ & 75 & TDA tailrace $^{(\mathrm{a})}$ & 50 & \\
\hline & & & Hood River & 25 & \\
\hline $5 / 30 / 2010$ & $5 / 31 / 2010$ & 25 & Hood River & 25 & \\
\hline \multirow[t]{2}{*}{$5 / 31 / 2010$} & $6 / 1 / 2010$ & 48 & TDA tailrace & 24 & \\
\hline & & & Hood River & 24 & \\
\hline
\end{tabular}

(a) Two releases (0800-0900 hours and 1900-2000 hours).

(b) Sacrificed to reach dead tagged fish quota for spring. 
Table A.2. 2010 Juvenile Steelhead Tagged at John Day Dam and Released Live at Three Sites

\begin{tabular}{|c|c|c|c|c|c|}
\hline Tag Date & Release Date & Number Tagged & Release Location & Number Released & Mortalities \\
\hline $4 / 27 / 2010$ & $4 / 28 / 2010$ & 72 & Roosevelt & 71 & 1 \\
\hline $4 / 28 / 2010$ & $4 / 29 / 2010$ & 72 & Roosevelt & 72 & \\
\hline \multirow[t]{2}{*}{$4 / 29 / 2010$} & $4 / 30 / 2010$ & 97 & Roosevelt & 72 & \\
\hline & & & TDA tailrace & 25 & \\
\hline \multirow[t]{2}{*}{$4 / 30 / 2010$} & $5 / 1 / 2010$ & 97 & Roosevelt & 72 & \\
\hline & & & Hood River & 25 & \\
\hline \multirow[t]{3}{*}{$5 / 1 / 2010$} & $5 / 2 / 2010$ & 147 & Roosevelt & 72 & \\
\hline & & & TDA tailrace ${ }^{(a)}$ & 50 & \\
\hline & & & Hood River & 25 & \\
\hline \multirow[t]{2}{*}{$5 / 2 / 2010$} & $5 / 3 / 2010$ & 96 & Roosevelt & 72 & \\
\hline & & & Hood River & 24 & \\
\hline \multirow[t]{3}{*}{$5 / 3 / 2010$} & $5 / 4 / 2010$ & 150 & Roosevelt & 75 & \\
\hline & & & TDA tailrace $^{(a)}$ & 49 & 1 \\
\hline & & & Hood River & 25 & \\
\hline \multirow[t]{3}{*}{$5 / 4 / 2010$} & $5 / 5 / 2010$ & 105 & Roosevelt & 71 & \\
\hline & & & Hood River & 26 & \\
\hline & & & & & $8^{(\mathrm{b})}$ \\
\hline \multirow[t]{3}{*}{$5 / 5 / 2010$} & $5 / 6 / 2010$ & 147 & Roosevelt & 72 & \\
\hline & & & TDA tailrace $^{(a)}$ & 50 & \\
\hline & & & Hood River & 25 & \\
\hline \multirow[t]{2}{*}{$5 / 6 / 2010$} & $5 / 7 / 2010$ & 97 & Roosevelt & 72 & \\
\hline & & & Hood River & 25 & \\
\hline \multirow{3}{*}{$5 / 7 / 2010$} & $5 / 8 / 2010$ & 147 & Roosevelt & 72 & \\
\hline & & & TDA tailrace $^{(a)}$ & 50 & \\
\hline & & & Hood River & 25 & \\
\hline \multirow[t]{2}{*}{$5 / 8 / 2010$} & $5 / 9 / 2010$ & 97 & Roosevelt & 72 & \\
\hline & & & Hood River & 25 & \\
\hline \multirow[t]{3}{*}{$5 / 9 / 2010$} & $5 / 10 / 2010$ & 147 & Roosevelt & 72 & \\
\hline & & & TDA tailrace $^{(\mathrm{a})}$ & 50 & \\
\hline & & & Hood River & 25 & \\
\hline $5 / 10 / 2010$ & $5 / 11 / 2010$ & 27 & & & $27^{(\mathrm{b})}$ \\
\hline \multirow[t]{3}{*}{$5 / 11 / 2010$} & $5 / 12 / 2010$ & 147 & Roosevelt & 72 & \\
\hline & & & TDA tailrace ${ }^{(a)}$ & 50 & \\
\hline & & & Hood River & 25 & \\
\hline \multirow[t]{2}{*}{$5 / 12 / 2010$} & $5 / 13 / 2010$ & 192 & Roosevelt & 142 & \\
\hline & & & Hood River & 50 & \\
\hline \multirow[t]{3}{*}{$5 / 13 / 2010$} & $5 / 14 / 2010$ & 146 & Roosevelt & 72 & \\
\hline & & & TDA tailrace ${ }^{(a)}$ & 50 & \\
\hline & & & Hood River & 24 & \\
\hline \multirow[t]{2}{*}{$5 / 14 / 2010$} & $5 / 15 / 2010$ & 97 & Roosevelt & 72 & \\
\hline & & & Hood River & 25 & \\
\hline \multirow[t]{3}{*}{$5 / 15 / 2010$} & $5 / 16 / 2010$ & 146 & Roosevelt & 71 & \\
\hline & & & TDA tailrace $^{(a)}$ & 50 & \\
\hline & & & Hood River & 25 & \\
\hline \multirow[t]{2}{*}{$5 / 16 / 2010$} & $5 / 17 / 2010$ & 97 & Roosevelt & 72 & \\
\hline & & & Hood River & 25 & \\
\hline
\end{tabular}


Table A.2. (contd)

\begin{tabular}{|c|c|c|c|c|c|}
\hline Tag Date & Release Date & Number Tagged & Release Location & Number Released & Mortalities \\
\hline \multirow{3}{*}{$5 / 17 / 2010$} & $5 / 18 / 2010$ & 147 & Roosevelt & 72 & \\
\hline & & & TDA tailrace $^{(\mathrm{a})}$ & 50 & \\
\hline & & & Hood River & 25 & \\
\hline \multirow[t]{2}{*}{$5 / 18 / 2010$} & $5 / 19 / 2010$ & 97 & Roosevelt & 72 & \\
\hline & & & Hood River & 25 & \\
\hline \multirow[t]{3}{*}{$5 / 19 / 2010$} & $5 / 20 / 2010$ & 147 & Roosevelt & 72 & \\
\hline & & & TDA tailrace $^{(a)}$ & 50 & \\
\hline & & & Hood River & 25 & \\
\hline \multirow[t]{2}{*}{$5 / 20 / 2010$} & $5 / 21 / 2010$ & 97 & Roosevelt & 72 & \\
\hline & & & Hood River & 25 & \\
\hline \multirow[t]{3}{*}{$5 / 21 / 2010$} & $5 / 22 / 2010$ & 147 & Roosevelt & 72 & \\
\hline & & & TDA tailrace ${ }^{(a)}$ & 50 & \\
\hline & & & Hood River & 25 & \\
\hline \multirow[t]{2}{*}{$5 / 22 / 2010$} & $5 / 23 / 2010$ & 97 & Roosevelt & 72 & \\
\hline & & & Hood River & 25 & \\
\hline \multirow[t]{3}{*}{$5 / 23 / 2010$} & $5 / 24 / 2010$ & 147 & Roosevelt & 72 & \\
\hline & & & TDA tailrace $^{(a)}$ & 50 & \\
\hline & & & Hood River & 25 & \\
\hline \multirow[t]{2}{*}{$5 / 24 / 2010$} & $5 / 25 / 2010$ & 97 & Roosevelt & 72 & \\
\hline & & & Hood River & 25 & \\
\hline \multirow[t]{3}{*}{$5 / 25 / 2010$} & $5 / 26 / 2010$ & 147 & Roosevelt & 72 & \\
\hline & & & TDA tailrace $^{(a)}$ & 50 & \\
\hline & & & Hood River & 25 & \\
\hline \multirow[t]{2}{*}{$5 / 26 / 2010$} & $5 / 27 / 2010$ & 97 & Roosevelt & 72 & \\
\hline & & & Hood River & 25 & \\
\hline \multirow[t]{3}{*}{$5 / 27 / 2010$} & $5 / 28 / 2010$ & 147 & Roosevelt & 72 & \\
\hline & & & TDA tailrace ${ }^{(a)}$ & 50 & \\
\hline & & & Hood River & 25 & \\
\hline \multirow[t]{2}{*}{$5 / 28 / 2010$} & $5 / 29 / 2010$ & 83 & Roosevelt & 58 & \\
\hline & & & Hood River & 25 & \\
\hline \multirow[t]{2}{*}{$5 / 29 / 2010$} & $5 / 30 / 2010$ & 75 & TDA tailrace ${ }^{(a)}$ & 50 & \\
\hline & & & Hood River & 25 & \\
\hline $5 / 30 / 2010$ & $5 / 31 / 2010$ & 25 & Hood River & 25 & \\
\hline \multirow[t]{2}{*}{$5 / 31 / 2010$} & $6 / 1 / 2010$ & 49 & TDA tailrace & 25 & \\
\hline & & & Hood River & 24 & \\
\hline
\end{tabular}

(a) Two releases (0800-0900 hours and 1900-2000 hours).

(b) Sacrificed to reach a dead tagged fish quota for spring. 
Table A.3. 2010 Summer Subyearling Chinook Salmon Smolts Tagged at John Day Dam and Released Live at Three Sites

\begin{tabular}{|c|c|c|c|c|c|}
\hline Tag Date & Release Date & Number Tagged & Release Location & Number Released & Mortalities \\
\hline $6 / 12 / 2010$ & $6 / 13 / 2010$ & 89 & Roosevelt & 89 & \\
\hline $6 / 13 / 2010$ & $6 / 14 / 2010$ & 88 & Roosevelt & 88 & \\
\hline $6 / 14 / 2010$ & $6 / 15 / 2010$ & 114 & $\begin{array}{l}\text { Roosevelt } \\
\text { TDA tailrace }\end{array}$ & $\begin{array}{l}89 \\
25\end{array}$ & \\
\hline $6 / 15 / 2010$ & $6 / 16 / 2010$ & 114 & $\begin{array}{l}\text { Roosevelt } \\
\text { Hood River }\end{array}$ & $\begin{array}{l}89 \\
25\end{array}$ & \\
\hline $6 / 16 / 2010$ & $6 / 17 / 2010$ & 165 & $\begin{array}{l}\text { Roosevelt } \\
\text { TDA tailrace } \\
\text { Hood River }\end{array}$ & $\begin{array}{l}89 \\
50 \\
\\
25\end{array}$ & 1 \\
\hline $6 / 17 / 2010$ & $6 / 18 / 2010$ & 114 & $\begin{array}{l}\text { Roosevelt } \\
\text { Hood River }\end{array}$ & $\begin{array}{l}89 \\
24\end{array}$ & 1 \\
\hline $6 / 18 / 2010$ & $6 / 19 / 2010$ & 177 & $\begin{array}{c}\text { Roosevelt } \\
\text { TDA tailrace } \\
\text { Hood River }\end{array}$ & $\begin{array}{l}88 \\
50 \\
25\end{array}$ & $\begin{array}{c}1 \\
13^{(\mathrm{b})}\end{array}$ \\
\hline $6 / 19 / 2010$ & $6 / 20 / 2010$ & 114 & $\begin{array}{l}\text { Roosevelt } \\
\text { Hood River }\end{array}$ & $\begin{array}{l}89 \\
25\end{array}$ & \\
\hline $6 / 20 / 2010$ & $6 / 21 / 2010$ & 164 & $\begin{array}{c}\text { Roosevelt } \\
\text { TDA tailrace }^{(a)} \\
\text { Hood River }\end{array}$ & $\begin{array}{l}89 \\
50 \\
25\end{array}$ & \\
\hline $6 / 21 / 2010$ & $6 / 22 / 2010$ & 113 & $\begin{array}{l}\text { Roosevelt } \\
\text { Hood River }\end{array}$ & $\begin{array}{l}89 \\
24\end{array}$ & \\
\hline $6 / 22 / 2010$ & $6 / 23 / 2010$ & 164 & $\begin{array}{c}\text { Roosevelt } \\
\text { TDA tailrace }^{(a)} \\
\text { Hood River }\end{array}$ & $\begin{array}{l}89 \\
50 \\
25\end{array}$ & \\
\hline $6 / 23 / 2010$ & $6 / 24 / 2010$ & 115 & $\begin{array}{l}\text { Roosevelt } \\
\text { Hood River }\end{array}$ & $\begin{array}{l}89 \\
26\end{array}$ & \\
\hline $6 / 24 / 2010$ & $6 / 25 / 2010$ & 135 & $\begin{array}{c}\text { Roosevelt } \\
\text { TDA tailrace } \\
\text { Hood River }\end{array}$ & $\begin{array}{l}75 \\
40 \\
20\end{array}$ & \\
\hline $6 / 25 / 2010$ & $6 / 26 / 2010$ & 128 & $\begin{array}{l}\text { Roosevelt } \\
\text { Hood River }\end{array}$ & $\begin{array}{l}89 \\
25\end{array}$ & $14^{(\mathrm{b})}$ \\
\hline $6 / 26 / 2010$ & $6 / 27 / 2010$ & 162 & $\begin{array}{c}\text { Roosevelt } \\
\text { TDA tailrace }^{(a)} \\
\text { Hood River }\end{array}$ & $\begin{array}{l}89 \\
50 \\
23\end{array}$ & \\
\hline $6 / 27 / 2010$ & $6 / 28 / 2010$ & 116 & $\begin{array}{l}\text { Roosevelt } \\
\text { Hood River }\end{array}$ & $\begin{array}{l}90 \\
25\end{array}$ & 1 \\
\hline $6 / 28 / 2010$ & $6 / 29 / 2010$ & 165 & $\begin{array}{c}\text { Roosevelt } \\
\text { TDA tailrace } \\
\text { Hood River }\end{array}$ & $\begin{array}{l}90 \\
49 \\
24\end{array}$ & $\begin{array}{l}1 \\
1\end{array}$ \\
\hline $6 / 29 / 2010$ & $6 / 30 / 2010$ & 114 & $\begin{array}{l}\text { Roosevelt } \\
\text { Hood River }\end{array}$ & $\begin{array}{l}89 \\
25\end{array}$ & \\
\hline
\end{tabular}


Table A.3. (contd)

\begin{tabular}{|c|c|c|c|c|c|}
\hline Tag Date & Release Date & Number Tagged & Release Location & Number Released & Mortalities \\
\hline \multirow{3}{*}{$6 / 30 / 2010$} & $7 / 1 / 2010$ & 193 & Roosevelt & 103 & \\
\hline & & & TDA tailrace ${ }^{(\mathrm{a})}$ & 60 & \\
\hline & & & Hood River & 30 & \\
\hline \multirow[t]{2}{*}{ 7/1/2010 } & $7 / 2 / 2010$ & 113 & Roosevelt & 89 & \\
\hline & & & Hood River & 23 & 1 \\
\hline \multirow[t]{3}{*}{$7 / 2 / 2010$} & $7 / 3 / 2010$ & 164 & Roosevelt & 89 & \\
\hline & & & TDA tailrace ${ }^{(a)}$ & 50 & \\
\hline & & & Hood River & 25 & \\
\hline \multirow[t]{2}{*}{ 7/3/2010 } & $7 / 4 / 2010$ & 114 & Roosevelt & 89 & \\
\hline & & & Hood River & 25 & \\
\hline \multirow[t]{3}{*}{$7 / 4 / 2010$} & $7 / 5 / 2010$ & 164 & Roosevelt & 89 & \\
\hline & & & TDA tailrace ${ }^{(\mathrm{a})}$ & 50 & \\
\hline & & & Hood River & 25 & \\
\hline \multirow[t]{3}{*}{ 7/5/2010 } & $7 / 6 / 2010$ & 125 & Roosevelt & 88 & 1 \\
\hline & & & Hood River & 25 & \\
\hline & & & & & $11^{(\mathrm{b})}$ \\
\hline \multirow[t]{3}{*}{$7 / 6 / 2010$} & $7 / 7 / 2010$ & 164 & Roosevelt & 89 & \\
\hline & & & TDA tailrace ${ }^{(a)}$ & 50 & \\
\hline & & & Hood River & 25 & \\
\hline \multirow[t]{2}{*}{ 7/7/2010 } & $7 / 8 / 2010$ & 114 & Roosevelt & 89 & \\
\hline & & & Hood River & 25 & \\
\hline \multirow[t]{3}{*}{$7 / 8 / 2010$} & $7 / 9 / 2010$ & 163 & Roosevelt & 88 & \\
\hline & & & TDA tailrace ${ }^{(a)}$ & 49 & 1 \\
\hline & & & Hood River & 25 & \\
\hline \multirow[t]{3}{*}{ 7/9/2010 } & $7 / 10 / 2010$ & 129 & Roosevelt & 89 & \\
\hline & & & Hood River & 25 & \\
\hline & & & & & $15^{(\mathrm{b})}$ \\
\hline \multirow[t]{3}{*}{$7 / 10 / 2010$} & $7 / 11 / 2010$ & 163 & Roosevelt & 89 & \\
\hline & & & TDA tailrace ${ }^{(a)}$ & 50 & \\
\hline & & & Hood River & 23 & 1 \\
\hline \multirow[t]{2}{*}{$7 / 11 / 2010$} & $7 / 12 / 2010$ & 115 & Roosevelt & 90 & \\
\hline & & & Hood River & 24 & 1 \\
\hline \multirow[t]{3}{*}{$7 / 12 / 2010$} & $7 / 13 / 2010$ & 166 & Roosevelt & 90 & \\
\hline & & & TDA tailrace ${ }^{(\mathrm{a})}$ & 50 & \\
\hline & & & Hood River & 25 & 1 \\
\hline \multirow[t]{2}{*}{$7 / 13 / 2010$} & $7 / 14 / 2010$ & 115 & Roosevelt & 90 & \\
\hline & & & Hood River & 25 & \\
\hline \multirow[t]{2}{*}{$7 / 14 / 2010$} & $7 / 15 / 2010$ & 82 & TDA tailrace ${ }^{(a)}$ & 52 & \\
\hline & & & Hood River & 30 & \\
\hline \multirow[t]{2}{*}{$7 / 15 / 2010$} & $7 / 16 / 2010$ & 31 & Hood River & 29 & \\
\hline & & & & & $2^{(\mathrm{b})}$ \\
\hline \multirow[t]{2}{*}{$7 / 16 / 2010$} & $7 / 17 / 2010$ & 50 & TDA tailrace ${ }^{(a)}$ & 25 & \\
\hline & & & Hood River & 25 & \\
\hline
\end{tabular}

(a) Two releases (0800-0900 hours and 1900-2000 hours).

(b) Sacrificed to reach a dead tagged fish quota for summer. 


\section{Appendix B}

Hydrophone and Autonomous Node Deployment Tables 


\section{Appendix B}

\section{Hydrophone and Autonomous Node Deployment Tables}

Table B.1. Hydrophone Locations in the Bonneville Dam-Face Array in 2010

\begin{tabular}{|c|c|c|c|}
\hline Hydrophone Name & Latitude (NAD83) & Longitude (NAD83) & Elevation (NAVD88, $\mathrm{ft}$ ) \\
\hline BS_00_D & 45.6457754 & -121.9406238 & 43.25 \\
\hline BS_00_S & 45.6457754 & -121.9406238 & 70.08 \\
\hline BS_01_D & 45.6456319 & -121.9406189 & 43.26 \\
\hline BS_01_S & 45.6456319 & -121.9406189 & 70.09 \\
\hline BS_02_D & 45.6454679 & -121.9406235 & 42.38 \\
\hline BS_02_S & 45.6454679 & -121.9406235 & 70.25 \\
\hline BS_03_D & 45.6453039 & -121.9406281 & 42.72 \\
\hline BS_03_S & 45.6453039 & -121.9406281 & 70.64 \\
\hline BS_04_D & 45.6451386 & -121.9406335 & 42.88 \\
\hline BS_04_S & 45.6451386 & -121.9406335 & 70.59 \\
\hline BS_05_D & 45.6449734 & -121.9406385 & 42.55 \\
\hline BS_05_S & 45.6449734 & -121.9406385 & 70.67 \\
\hline BS_06_D & 45.6448104 & -121.9406426 & 42.42 \\
\hline BS_06_S & 45.6448104 & -121.9406426 & 70.34 \\
\hline BS_07_D & 45.6446455 & -121.9406479 & 42.47 \\
\hline BS_07_S & 45.6446455 & -121.9406479 & 70.39 \\
\hline BS_08_D & 45.6444806 & -121.9406530 & 43.73 \\
\hline BS_08_S & 45.6444806 & -121.9406530 & 71.27 \\
\hline BS_09_D & 45.6443162 & -121.9406579 & 43.72 \\
\hline BS_09_S & 45.6443162 & -121.9406579 & 71.38 \\
\hline BS_10_D & 45.6441527 & -121.9406624 & 43.31 \\
\hline BS_10_S & 45.6441527 & -121.9406624 & 70.60 \\
\hline BS_11_D & 45.6439873 & -121.9406677 & 43.19 \\
\hline BS_11_S & 45.6439873 & -121.9406677 & 70.86 \\
\hline BS_12_D & 45.6438228 & -121.9406723 & 42.63 \\
\hline BS_12_S & 45.6438228 & -121.9406723 & 70.38 \\
\hline BS_13_D & 45.6436600 & -121.9406773 & 43.22 \\
\hline BS_13_S & 45.6436600 & -121.9406773 & 70.93 \\
\hline BS_14_D & 45.6434942 & -121.9406824 & 43.12 \\
\hline BS_14_S & 45.6434942 & -121.9406824 & 70.78 \\
\hline BS_15_D & 45.6433303 & -121.9406880 & 43.26 \\
\hline BS_15_S & 45.6433303 & -121.9406880 & 70.80 \\
\hline BS_16_D & 45.6431654 & -121.9406920 & 42.37 \\
\hline BS_16_S & 45.6431654 & -121.9406920 & 69.79 \\
\hline
\end{tabular}


Table B.1. (contd)

\begin{tabular}{|c|c|c|c|}
\hline Hydrophone Name & Latitude (NAD83) & Longitude (NAD83) & Elevation (NAVD88, ft) \\
\hline BS_17_D & 45.6429996 & -121.9406974 & 41.45 \\
\hline BS_17_S & 45.6429996 & -121.9406974 & 69.20 \\
\hline BS_18_D & 45.6428602 & -121.9407015 & 42.98 \\
\hline BS_18_S & 45.6428602 & -121.9407015 & 70.85 \\
\hline BPH1NWW & 45.6403227 & -121.9457555 & 72.14 \\
\hline BPH1SWW & 45.6403065 & -121.9457652 & 67.53 \\
\hline BSS_F1S & 45.6390935 & -121.9468644 & 67.59 \\
\hline B01_F1D & 45.6391509 & -121.9467887 & 16.09 \\
\hline B01_F1S & 45.6391630 & -121.9468228 & 66.45 \\
\hline B01_02D & 45.6393625 & -121.9466646 & 16.08 \\
\hline B01_02S & 45.6393721 & -121.9467003 & 66.44 \\
\hline B02_03D & 45.6395733 & -121.9465415 & 16.14 \\
\hline B02_03S & 45.6395811 & -121.9465780 & 66.50 \\
\hline B03_04D & 45.6397863 & -121.9464179 & 15.97 \\
\hline B03_04S & 45.6397915 & -121.9464554 & 66.33 \\
\hline B04_05D & 45.6399809 & -121.9463025 & 15.99 \\
\hline B04_05S & 45.6399945 & -121.9463354 & 66.35 \\
\hline B05_06D & 45.6401955 & -121.9461767 & 15.88 \\
\hline B05_06S & 45.6402045 & -121.9462127 & 66.24 \\
\hline B06_7ND & 45.6404088 & -121.9460488 & 23.57 \\
\hline B06_7NS & 45.6404088 & -121.9460488 & 66.45 \\
\hline B06_7SD & 45.6403921 & -121.9460630 & 18.04 \\
\hline B06_7SS & 45.6403921 & -121.9460630 & 60.97 \\
\hline B07_08D & 45.6406087 & -121.9459354 & 15.76 \\
\hline B07_08S & 45.6406199 & -121.9459701 & 66.12 \\
\hline B08_09D & 45.6408202 & -121.9458109 & 15.71 \\
\hline B08_09S & 45.6408290 & -121.9458470 & 66.07 \\
\hline B09_10D & 45.6410285 & -121.9456890 & 15.84 \\
\hline B09_10S & 45.6410370 & -121.9457253 & 66.20 \\
\hline B1N_10D & 45.6412207 & -121.9455825 & 15.83 \\
\hline B1N_10S & 45.6412207 & -121.9455825 & 66.19 \\
\hline BNORWAL & 45.6412335 & -121.9450736 & 74.09 \\
\hline B1S_SW1 & 45.6386370 & -121.9461653 & 66.90 \\
\hline BCC_11S & 45.6472569 & -121.9383610 & 71.52 \\
\hline BCC_11D & 45.6472491 & -121.9383485 & 58.94 \\
\hline B11_12D & 45.6474348 & -121.9380910 & 16.01 \\
\hline B11_12S & 45.6474492 & -121.9381139 & 69.81 \\
\hline B12_13S & 45.6476410 & -121.9378682 & 69.58 \\
\hline B12_13D & 45.6476267 & -121.9378454 & 17.58 \\
\hline B13_14D & 45.6478239 & -121.9375939 & 17.95 \\
\hline B13_14S & 45.6478382 & -121.9376167 & 69.95 \\
\hline B14_15S & 45.6480298 & -121.9373713 & 69.69 \\
\hline
\end{tabular}


Table B.1. (contd)

\begin{tabular}{cccc}
\hline Hydrophone Name & Latitude (NAD83) & Longitude (NAD83) & Elevation (NAVD88, ft) \\
\hline B14_15D & 45.6480155 & -121.9373484 & 17.69 \\
\hline B15_16D & 45.6482032 & -121.9371106 & 17.89 \\
\hline B15_16S & 45.6482176 & -121.9371335 & 69.89 \\
\hline B16_17S & 45.6484092 & -121.9368895 & 69.56 \\
\hline B16_17D & 45.6483949 & -121.9368667 & 17.56 \\
\hline B17_18D & 45.6485863 & -121.9366197 & 17.76 \\
\hline B17_18S & 45.6486007 & -121.9366425 & 69.76 \\
\hline B18_19S & 45.6487928 & -121.9363969 & 69.81 \\
\hline B18_19D & 45.6487785 & -121.9363741 & 17.81 \\
\hline B19_NOS & 45.6489836 & -121.9361548 & 71.57 \\
\hline B15A_T1 & 45.6479821 & -121.9372776 & 72.97 \\
\hline B15C_T2 & 45.6480989 & -121.9371235 & 72.99 \\
\hline B17A_T3 & 45.6483647 & -121.9367849 & 72.84 \\
\hline B18B_T4 & 45.6486162 & -121.9364637 & 73.37 \\
\hline BGS_C01 & 45.6468219 & -121.9383161 & 75.74 \\
\hline BGS_C02 & 45.6466241 & -121.9380157 & 75.42 \\
\hline BGS_C03 & 45.6464991 & -121.9378074 & 75.70 \\
\hline BGS_C04 & 45.6463806 & -121.9374317 & 75.61 \\
\hline BGS_C05 & 45.6462957 & -121.9369925 & 75.74 \\
\hline BGS_C06 & 45.6462442 & -121.9366974 & 75.68 \\
\hline BGS_C07 & 45.6462059 & -121.9363118 & 75.72 \\
\hline BGS_W01 & 45.6483706 & -121.9352006 & 75.73 \\
\hline BGS_W02 & 45.6481994 & -121.9348416 & 75.59 \\
\hline BGS_W03 & 45.6480165 & -121.9345007 & 75.72 \\
\hline BGS_W04 & 45.6478505 & -121.9338666 & 75.57 \\
\hline BGS_W06 & 45.6477023 & -121.9334464 & 75.56 \\
\hline BGS_W07 & 45.6475595 & -121.9330686 & 75.58 \\
\hline BGS_W08 & 45.6474384 & -121.9325314 & \\
\hline & & & \\
\hline & & & \\
\hline
\end{tabular}


Table B.2. Approximate Global Positioning System Coordinates of Autonomous Nodes Deployed in Arrays Just Above and Below Bonneville Dam in 2010. Array_Node is a concatenation of an array name and an autonomous node number. The array name is a concatenation of "CR" for Columbia River, with a three-digit number corresponding to river kilometer upstream of the mouth of the Columbia River. Nodes within an array are numbered from the Washington to the Oregon shore.

\begin{tabular}{lccc}
\hline Array_Node & Array Function & Latitude Degrees North & Longitude Degrees West \\
\hline CR236.0_01 & BON Forebay & 45.6509740 & -121.9203458 \\
\hline CR236.0_02 & & 45.6504350 & -121.9198846 \\
\hline CR236.0_03 & & 45.6498599 & -121.9193208 \\
\hline CR236.0_04 & & 45.6493209 & -121.9188596 \\
\hline CR233.0_01 & BON Egress & 45.6350168 & -121.9624832 \\
\hline CR233.0_02 & & 45.6350270 & -121.9613769 \\
\hline CR233.0_03 & & 45.6346313 & -121.9606050 \\
\hline CR153.0_01 & BON Primary & 45.7449562 & -122.7858224 \\
\hline CR153.0_02 & & 45.7445609 & -122.7660408 \\
\hline CR153.0_03 & & 45.7465749 & -122.7629473 \\
\hline CR153.0_04 & & 45.7452083 & -122.7637150 \\
\hline CR153.0_05 & & 45.7441297 & -122.7652561 \\
\hline CR113.0_01 & BON Secondary & 46.0633259 & -122.8693984 \\
\hline CR113.0_02 & & 46.0707306 & -122.8868271 \\
\hline CR113.0_03 & & 46.0699943 & -122.8872084 \\
\hline CR113.0_04 & & 46.0693229 & -122.8888071 \\
\hline CR113.0_05 & & 46.0694009 & -122.8900944 \\
\hline CR113.0_06 & & 46.0711953 & -122.8919111 \\
\hline CR113.0_07 & & 46.0687756 & -122.8902994 \\
\hline CR113.0_08 & & 46.0691116 & -122.8916534 \\
\hline CR113.0_09 & & 46.0684816 & -122.8922447 \\
\hline CR113.0_10 & BON Tertiary & 46.0689276 & -122.8939764 \\
\hline CR086.2_01 & 46.1860936 & -123.1806843 \\
\hline CR086.2_02 & & 46.1859806 & -123.1792560 \\
\hline CR086.2_03 & 46.1849006 & -123.1805780 \\
\hline CR086.2_04 & & 46.1841513 & -123.1789230 \\
\hline CR086.2_05 & & 46.1840586 & -123.1778617 \\
\hline CR086.2_06 & 46.1834166 & -123.1784803 \\
\hline & & & \\
\hline
\end{tabular}




\section{Appendix C}

\section{Capture Histories}




\section{Appendix C}

\section{Capture Histories}

This appendix contains detailed capture histories for each of the three runs of fish studied at Bonneville Dam in 2010. In capture history tables, the headings of columns 2 through 9 have three digits and each digit represents a detection (1) or non-detection (0) at three successive survival arrays (CR153, CR113, and CR086).

\section{C.1 Capture Histories of Yearling Chinook Salmon in Spring}

\section{C.1.1 Bonneville Dam Passage}

Table C.1. Bonneville Dam Passage Capture History for Yearling Chinook Salmon

\begin{tabular}{ccccccccc}
\hline & 111 & 011 & 101 & 001 & 110 & 010 & 100 & 000 \\
\hline Number of Fish & 2278 & 525 & 141 & 44 & 121 & 48 & 27 & 174 \\
\hline
\end{tabular}

\section{C.1.2 Forebay and Dam Passage}

Table C.2. Forebay Virtual Release Capture History for Yearling Chinook Salmon

\begin{tabular}{ccccccccc}
\hline & 111 & 011 & 101 & 001 & 110 & 010 & 100 & 000 \\
\hline Number of Fish & 2287 & 527 & 142 & 44 & 121 & 48 & 27 & 177 \\
\hline
\end{tabular}

\section{C.1.3 B1 Sluiceway Passage}

Table C.3. B1 Sluiceway Virtual Release Capture History for Yearling Chinook Salmon

\begin{tabular}{ccccccccc}
\hline & 111 & 011 & 101 & 001 & 110 & 010 & 100 & 000 \\
\hline Number of Fish & 34 & 20 & 4 & 1 & 1 & 1 & 1 & 2 \\
\hline
\end{tabular}

\section{C.1.4 B1 Turbine Passage}

Table C.4. B1 Turbine Virtual Release Capture History for Yearling Chinook Salmon

\begin{tabular}{ccccccccc}
\hline & 111 & 011 & 101 & 001 & 110 & 010 & 100 & 000 \\
\hline Number of Fish & 68 & 40 & 8 & 2 & 5 & 1 & 2 & 3 \\
\hline
\end{tabular}




\section{C.1.5 Spillway Passage}

Table C.5. Bonneville Spillway Virtual Release Capture History for Yearling Chinook Salmon

\begin{tabular}{ccccccccc}
\hline & 111 & 011 & 101 & 001 & 110 & 010 & 100 & 000 \\
\hline Number of Fish & 1175 & 260 & 80 & 23 & 63 & 32 & 12 & 121 \\
\hline
\end{tabular}

\section{C.1.6 B2CC Passage}

Table C.6. B2CC Passage Capture History for Yearling Chinook Salmon

\begin{tabular}{ccccccccc}
\hline & 111 & 011 & 101 & 001 & 110 & 010 & 100 & 000 \\
\hline Number of Fish & 488 & 78 & 15 & 9 & 23 & 7 & 6 & 8 \\
\hline
\end{tabular}

\section{C.1.7 B2 JBS Passage}

Table C.7. B2 JBS Passage Capture History for Yearling Chinook Salmon

\begin{tabular}{lcccccccc}
\hline & 111 & 011 & 101 & 001 & 110 & 010 & 100 & 000 \\
\hline Number of Fish & 152 & 36 & 9 & 4 & 6 & 3 & 2 & 5 \\
\hline
\end{tabular}

\section{C.1.8 B2 Turbine Passage}

Table C.8. B2 Turbine Passage Capture History for Yearling Chinook Salmon

\begin{tabular}{lcccccccc}
\hline & 111 & 011 & 101 & 001 & 110 & 010 & 100 & 000 \\
\hline Number of Fish & 356 & 91 & 25 & 5 & 23 & 4 & 4 & 25 \\
\hline
\end{tabular}

\section{C.2 Capture Histories of Juvenile Steelhead Salmon in Spring}

\section{C.2.1 Bonneville Dam Passage}

Table C.9. Bonneville Dam Passage Capture History for Juvenile Steelhead

\begin{tabular}{lcccccccc}
\hline & 111 & 011 & 101 & 001 & 110 & 010 & 100 & 000 \\
\hline Number of Fish & 2089 & 642 & 140 & 72 & 148 & 41 & 36 & 205 \\
\hline
\end{tabular}




\section{C.2.2 Forebay and Dam Passage}

Table C.10. Forebay Virtual Release Capture History for Juvenile Steelhead

\begin{tabular}{ccccccccc}
\hline & 111 & 011 & 101 & 001 & 110 & 010 & 100 & 000 \\
\hline Number of Fish & 2088 & 642 & 141 & 73 & 149 & 41 & 36 & 206 \\
\hline
\end{tabular}

\section{C.2.3 B1 Sluiceway Passage}

Table C.11. B1 Sluiceway Virtual Release Capture History for Juvenile Steelhead

\begin{tabular}{lcccccccc}
\hline & 111 & 011 & 101 & 001 & 110 & 010 & 100 & 000 \\
\hline Number of Fish & 44 & 19 & 4 & 3 & 4 & 0 & 2 & 4 \\
\hline
\end{tabular}

\section{C.2.4 B1 Turbine Passage}

Table C.12. B1 Turbine Virtual Release Capture History for Juvenile Steelhead

\begin{tabular}{lcccccccc}
\hline & 111 & 011 & 101 & 001 & 110 & 010 & 100 & 000 \\
\hline Number of Fish & 57 & 33 & 4 & 6 & 3 & 1 & 0 & 12 \\
\hline
\end{tabular}

\section{C.2.5 Spillway Passage}

Table C.13. Bonneville Spillway Virtual Release Capture History for Juvenile Steelhead

\begin{tabular}{ccccccccc}
\hline & 111 & 011 & 101 & 001 & 110 & 010 & 100 & 000 \\
\hline Number of Fish & 828 & 262 & 69 & 18 & 64 & 15 & 17 & 91 \\
\hline
\end{tabular}

\section{C.2.6 B2CC Passage}

Table C.14. B2CC Passage Capture History for Juvenile Steelhead

\begin{tabular}{ccccccccc}
\hline & 111 & 011 & 101 & 001 & 110 & 010 & 100 & 000 \\
\hline Number of Fish & 681 & 194 & 38 & 21 & 42 & 16 & 8 & 30 \\
\hline
\end{tabular}




\section{C.2.7 B2 JBS Passage}

Table C.15. B2 JBS Passage Capture History for Juvenile Steelhead

\begin{tabular}{ccccccccc}
\hline & 111 & 011 & 101 & 001 & 110 & 010 & 100 & 000 \\
\hline Number of Fish & 134 & 31 & 10 & 8 & 9 & 2 & 0 & 5 \\
\hline
\end{tabular}

\section{C.2.8 B2 Turbine Passage}

Table C.16. B2 Turbine Passage Capture History for Juvenile Steelhead

\begin{tabular}{lcccccccc}
\hline & 111 & 011 & 101 & 001 & 110 & 010 & 100 & 000 \\
\hline Number of Fish & 343 & 103 & 15 & 16 & 26 & 7 & 9 & 55 \\
\hline
\end{tabular}

\section{C.3 Capture Histories of Subyearling Chinook Salmon in Spring}

\section{C.3.1 Bonneville Dam Passage}

Table C.17. Bonneville Dam Passage Capture History for Subyearling Chinook Salmon

\begin{tabular}{lcccccccc}
\hline & 111 & 011 & 101 & 001 & 110 & 010 & 100 & 000 \\
\hline Number of Fish $^{(\mathrm{a})}$ & 1044 & 160 & 52 & 8 & 0 & 0 & 86 & 10 \\
\hline
\end{tabular}

(a) After BON dam-face virtual release of subyearlings from TDA tailrace and Hood River releases only.

\section{C.3.2 Bonneville Dam Passage (85 kcfs day \& 120 kcfs night spill treatment)}

Table C.18. Bonneville Dam Passage Capture History for Subyearling Chinook Salmon during the 8- kcfs Day and 120-kcfs Night Spill Treatment (Figure 3.5)

\begin{tabular}{ccccccccc}
\hline & 111 & 011 & 101 & 001 & 110 & 010 & 100 & 000 \\
\hline Number of Fish $^{(\mathrm{a})}$ & 572 & 27 & 19 & 1 & 0 & 0 & 19 & 2 \\
\hline
\end{tabular}

(a) After BON dam-face virtual release of subyearlings from all upstream releases (Roosevelt, The Dalles Dam tailrace, and Hood River). 


\section{C.3.3 Bonneville Dam Passage (24-h, 95-kcfs spill treatment)}

Table C.19. Bonneville Dam Passage Capture History for Subyearling Chinook Salmon During the 24-h, 95-kcfs Spill Treatment (Figure 3.5)

\begin{tabular}{|c|c|c|c|c|c|c|c|c|}
\hline & 111 & 011 & 101 & 001 & 110 & 010 & 100 & 000 \\
\hline Number of Fish ${ }^{(a)}$ & 700 & 49 & 28 & 1 & 0 & 0 & 22 & 1 \\
\hline \multicolumn{9}{|c|}{$\begin{array}{l}\text { (a) After Bonneville dam-face virtual release of subyearlings from all upstream releases (Roosevelt, The Dalles } \\
\text { Dam tailrace, and Hood River). }\end{array}$} \\
\hline
\end{tabular}

\section{C.3.4 Forebay and Dam Passage}

Table C.20. Forebay Virtual Release Capture History for Subyearling Chinook Salmon

\begin{tabular}{lllllllll}
\hline & 111 & 011 & 101 & 001 & 110 & 010 & 100 & 000 \\
\hline Number of Fish $^{(a)}$ & 1129 & 1129 & 1129 & 1129 & 1129 & 1129 & 1129 & 1129 \\
\hline
\end{tabular}

(a) After Bonneville Dam forebay virtual release of subyearlings from The Dalles Dam tailrace and Hood River releases only.

\section{C.3.5 B1 Sluiceway Passage}

Table C.21. B1 Sluiceway Virtual Release Capture History for Subyearling Chinook Salmon

\begin{tabular}{lcccccccc}
\hline & 111 & 011 & 101 & 001 & 110 & 010 & 100 & 000 \\
\hline Number of Fish & 128 & 25 & 11 & 0 & 14 & 2 & 4 & 12 \\
\hline
\end{tabular}

\section{C.3.6 B1 Turbine Passage}

Table C.22. B1 Turbine Virtual Release Capture History for Subyearling Chinook Salmon

\begin{tabular}{lcccccccc}
\hline & 111 & 011 & 101 & 001 & 110 & 010 & 100 & 000 \\
\hline Number of Fish & 378 & 89 & 12 & 5 & 39 & 15 & 9 & 21 \\
\hline
\end{tabular}

\section{C.3.7 Spillway Passage}

Table C.23. Bonneville Spillway Virtual Release Capture History for Subyearling Chinook Salmon

\begin{tabular}{ccccccccc}
\hline & 111 & 011 & 101 & 001 & 110 & 010 & 100 & 000 \\
\hline Number of Fish & 1238 & 188 & 66 & 11 & 109 & 16 & 30 & 129 \\
\hline
\end{tabular}




\section{C.3.8 B2CC Passage}

Table C.24. B2CC Passage Capture History for Subyearling Chinook Salmon

\begin{tabular}{ccccccccc}
\hline & 111 & 011 & 101 & 001 & 110 & 010 & 100 & 000 \\
\hline Number of Fish & 249 & 24 & 11 & 1 & 4 & 5 & 7 & 10 \\
\hline
\end{tabular}

\section{C.3.9 B2 JBS Passage}

Table C.25. B2 JBS Passage Capture History for Subyearling Chinook Salmon

\begin{tabular}{ccccccccc}
\hline & 111 & 011 & 101 & 001 & 110 & 010 & 100 & 000 \\
\hline Number of Fish & 76 & 11 & 8 & 1 & 9 & 2 & 2 & 3 \\
\hline
\end{tabular}

\section{C.3.10 B2 Turbine Passage}

Table C.26. B2 Turbine Passage Capture History for Subyearling Chinook Salmon

\begin{tabular}{lcccccccc}
\hline & 111 & 011 & 101 & 001 & 110 & 010 & 100 & 000 \\
\hline Number of Fish & 332 & 49 & 10 & 1 & 14 & 2 & 1 & 28 \\
\hline
\end{tabular}


Appendix D

\section{Detection and Survival Probabilities}




\section{Appendix D}

\section{Detection and Survival Probabilities}

\section{D.1 Detection and Survival of Yearling Chinook Salmon}

\section{D.1.1 Bonneville Dam Passage}

Table D.1. Bonneville Dam Passage Detection and Survival Rates for Yearling Chinook Salmon Survival Detail:

\begin{tabular}{|l|c|c|c|c|}
\hline & \multicolumn{2}{|c|}{ CR234.0 to CR153.0 } & \multicolumn{2}{c|}{ CR153.0 to CR113.0 } \\
\hline & Estimate & s.e.† & Estimate & s.e. $^{*}$ \\
\hline Yearling Chinook - All Upstr & 0.9519 & 0.003968 & 0.9938 & 0.002057 \\
\hline
\end{tabular}

Capture Detail:

\begin{tabular}{|c|c|c|c|c|c|c|}
\hline & \multicolumn{2}{|c|}{ CR153.0 } & \multicolumn{2}{|c|}{ CR113.0 } & \multicolumn{2}{|c|}{ CR086.2 Survival*Capture } \\
\hline & Estimate & s.e.* & Estimate & s.e.* & Estimate & s.e.* \\
\hline Yearling Chinook - All Upstr & 0.8046 & 0.007057 & 0.9381 & 0.004409 & 0.9437 & 0.004250 \\
\hline
\end{tabular}

* Standard error is based on the inverse Hessian.

† Standard error is based on bootstrapping.

\section{D.1.2 Forebay and Dam Passage}

Table D.2. Forebay Virtual Release Detection and Survival Rates for Yearling Chinook Salmon Survival Detail:

\begin{tabular}{|l|c|c|c|c|}
\hline \hline & \multicolumn{2}{|c|}{ CR236.0 to CR153.0 } & \multicolumn{2}{c|}{ CR153.0 to CR113.0 } \\
\hline & Estimate & s.e.t & Estimate & s.e.* \\
\hline Yearling Chinook - All Upstr & 0.9513 & 0.004014 & 0.9939 & 0.002049 \\
\hline
\end{tabular}

\section{Capture Detail:}

\begin{tabular}{|l|c|c|c|c|c|c|}
\hline & \multicolumn{2}{|c|}{ CR153.0 } & \multicolumn{2}{c|}{ CR113.0 } & \multicolumn{2}{c|}{ CR086.2 Survival*Capture } \\
\hline & Estimate & s.e. $^{*}$ & Estimate & s.e. $^{*}$ & Estimate & s.e. $^{*}$ \\
\hline Yearling Chinook - All Upstr & 0.8047 & 0.007043 & 0.9380 & 0.004403 & 0.9439 & 0.004235 \\
\hline
\end{tabular}

* Standard error is based on the inverse Hessian.

† Standard error is based on bootstrapping. 


\section{D.1.3 B1 Sluiceway Passage}

Table D.3. B1 Sluiceway Virtual Release Detection and Survival Rates for Yearling Chinook Salmon Survival Detail:

\begin{tabular}{|l|c|c|c|c|}
\hline & \multicolumn{2}{|c|}{ CR234.0 to CR153.0 } & \multicolumn{2}{c|}{ CR153.0 to CR113.0 } \\
\hline & Estimate & s.e.† & Estimate & s.e.* \\
\hline Yearling Chinook - All Upstr & 0.9795 & 0.023829 & 0.9788 & 0.024905 \\
\hline
\end{tabular}

\section{Capture Detail:}

\begin{tabular}{|l|c|c|c|c|c|c|}
\hline & \multicolumn{2}{|c|}{ CR153.0 } & \multicolumn{2}{c|}{ CR113.0 } & \multicolumn{2}{c|}{ CR086.2 Survival ${ }^{*}$ Capture } \\
\hline & Estimate & s.e. $^{*}$ & Estimate & s.e. & Estimate & s.e. $^{*}$ \\
\hline Yearling Chinook - All Upstr & 0.6393 & 0.061482 & 0.9153 & 0.036258 & 0.9648 & 0.024812 \\
\hline
\end{tabular}

* Standard error is based on the inverse Hessian.

$\dagger$ Standard error is based on bootstrapping.

\section{D.1.4 B1 Turbine Passage}

Table D.4. B1 Turbine Virtual Release Detection and Survival Rates for Yearling Chinook Salmon Survival Detail:

\begin{tabular}{|l|c|c|c|c|}
\hline & \multicolumn{2}{|c|}{ CR234.0 to CR153.0 } & CR153.0 to CR113.0 \\
\hline & Estimate & s.e.t & Estimate & s.e. \\
\hline Yearling Chinook - All Upstr & 0.9871 & 0.014753 & 0.9810 & 0.017072 \\
\hline
\end{tabular}

\section{Capture Detail:}

\begin{tabular}{|l|c|c|c|c|c|c|}
\hline & \multicolumn{2}{|c|}{ CR153.0 } & \multicolumn{2}{c|}{ CR113.0 } & \multicolumn{2}{c|}{ CR086.2 Survival*Capture } \\
\hline & Estimate & s.e.* & Estimate & s.e. & Estimate & s.e. $^{*}$ \\
\hline Yearling Chinook - All Upstr & 0.6532 & 0.042741 & 0.9153 & 0.025638 & 0.9479 & 0.020926 \\
\hline
\end{tabular}

* Standard error is based on the inverse Hessian.

† Standard error is based on bootstrapping. 


\section{D.1.5 Spillway Passage}

Table D.5. Bonneville Spillway Virtual Release Detection and Survival Rates for Yearling Chinook Salmon

\section{Survival Detail:}

\begin{tabular}{|l|c|c|c|c|}
\hline & \multicolumn{2}{c|}{ CR234.0 to CR153.0 } & \multicolumn{2}{c|}{ CR153.0 to CR113.0 } \\
\hline & Estimate & s.e.t & Estimate & s.e. $^{*}$ \\
\hline Yearling Chinook - All Upstr & 0.9349 & 0.006142 & 0.9960 & 0.002672 \\
\hline
\end{tabular}

\section{Capture Detail:}

\begin{tabular}{|l|c|c|c|c|c|c|}
\hline \hline & \multicolumn{2}{|c|}{ CR153.0 } & \multicolumn{2}{c|}{ CR113.0 } & \multicolumn{2}{c|}{ CR086.2 Survival*Capture } \\
\hline & Estimate & s.e. & Estimate & s.e. & Estimate & s.e. $^{*}$ \\
\hline Yearling Chinook - All Upstr & 0.8071 & 0.009764 & 0.9330 & 0.006374 & 0.9385 & 0.006173 \\
\hline
\end{tabular}

* Standard error is based on the inverse Hessian.

† Standard error is based on bootstrapping.

\section{D.1.6 B2CC Passage}

Table D.6. B2CC Passage Detection and Survival Rates for Yearling Chinook Salmon

\section{Survival Detail:}

\begin{tabular}{|l|c|c|c|c|}
\hline & \multicolumn{2}{|c|}{ CR234.0 to CR153.0 } & \multicolumn{2}{c|}{ CR153.0 to CR113.0 } \\
\hline & Estimate & s.e.t & Estimate & s.e. $^{*}$ \\
\hline Yearling Chinook - All Upstr & 0.9909 & 0.004625 & 0.9916 & 0.004625 \\
\hline
\end{tabular}

\section{Capture Detail:}

\begin{tabular}{|l|c|c|c|c|c|c|}
\hline & \multicolumn{2}{|c|}{ CR153.0 } & \multicolumn{2}{c|}{ CR113.0 } & \multicolumn{2}{c|}{ CR086.2 Survival*Capture } \\
\hline & Estimate & s.e. & Estimate & s.e. & Estimate & s.e. $^{*}$ \\
\hline Yearling Chinook - All Upstr & 0.8484 & 0.014404 & 0.9593 & 0.008133 & 0.9502 & 0.008961 \\
\hline
\end{tabular}

* Standard error is based on the inverse Hessian.

† Standard error is based on bootstrapping. 


\section{D.1.7 B2 JBS Passage}

Table D.7. B2 JBS Passage Detection and Survival Rates for Yearling Chinook Salmon

\section{Survival Detail:}

\begin{tabular}{|l|c|c|c|c|}
\hline & \multicolumn{2}{|c|}{ CR234.0 to CR153.0 } & \multicolumn{2}{c|}{ CR153.0 to CR113.0 } \\
\hline & Estimate & s.e.t & Estimate & s.e.* \\
\hline Yearling Chinook - All Upstr & 0.9814 & 0.010443 & 0.9920 & 0.008447 \\
\hline
\end{tabular}

\section{Capture Detail:}

\begin{tabular}{|l|c|c|c|c|c|c|}
\hline \hline & \multicolumn{2}{|c|}{ CR153.0 } & \multicolumn{2}{c|}{ CR113.0 } & \multicolumn{2}{c|}{ CR086.2 Survival*Capture } \\
\hline & Estimate & s.e.* & Estimate & s.e.* $^{*}$ & Estimate & s.e.* $^{*}$ \\
\hline Yearling Chinook - All Upstr & 0.7952 & 0.027846 & 0.9353 & 0.017348 & 0.9549 & 0.014885 \\
\hline
\end{tabular}

* Standard error is based on the inverse Hessian.

† Standard error is based on bootstrapping.

\section{D.1.8 B2 Turbine Passage}

Table D.8. B2 Turbine Passage Detection and Survival Rates for Yearling Chinook Salmon

\section{Survival Detail:}

\begin{tabular}{|l|c|c|c|c|}
\hline & \multicolumn{2}{|c|}{ CR234.0 to CR153.0 } & \multicolumn{2}{c|}{ CR153.0 to CR113.0 } \\
\hline & Estimate & s.e.t & Estimate & s.e. $^{*}$ \\
\hline Yearling Chinook - All Upstr & 0.9568 & 0.009312 & 0.9946 & 0.004990 \\
\hline
\end{tabular}

\section{Capture Detail:}

\begin{tabular}{|l|c|c|c|c|c||c|}
\hline \hline & \multicolumn{2}{|c|}{ CR153.0 } & \multicolumn{2}{c|}{ CR113.0 } & \multicolumn{2}{c|}{ CR086.2 Survival ${ }^{*}$ Capture } \\
\hline & Estimate & s.e.* & Estimate & s.e.* & Estimate & s.e. $^{*}$ \\
\hline Yearling Chinook - All Upstr & 0.8016 & 0.017764 & 0.9371 & 0.011116 & 0.9436 & 0.010652 \\
\hline
\end{tabular}

* Standard error is based on the inverse Hessian.

$\uparrow$ Standard error is based on bootstrapping. 


\section{D.2 Detection and Survival of Juvenile Steelhead}

\section{D.2.1 Bonneville Dam Passage}

Table D.9. Bonneville Dam Passage Detection and Survival Rates for Juvenile Steelhead

Survival Detail:

\begin{tabular}{|l|c|c|c|c|}
\hline \hline & \multicolumn{2}{|c|}{ CR234.0 to CR153.0 } & \multicolumn{2}{c|}{ CR153.0 to CR113.0 } \\
\hline & Estimate & s.e.t & Estimate & s.e. \\
\hline Steelhead - All Upstream Sit & 0.9445 & 0.004329 & 0.9906 & 0.002524 \\
\hline
\end{tabular}

\section{Capture Detail:}

\begin{tabular}{|l|c|c|c|c|c|c|}
\hline & \multicolumn{2}{|c|}{ CR153.0 } & \multicolumn{2}{c|}{ CR113.0 } & \multicolumn{2}{c|}{ CR086.2 Survival ${ }^{*}$ Capture $^{*}$} \\
\hline & Estimate & s.e. $^{*}$ & Estimate & s.e. $^{*}$ & Estimate & s.e. $^{*}$ \\
\hline Steelhead - All Upstream Sit & 0.7589 & 0.007643 & 0.9280 & 0.004766 & 0.9358 & 0.004556 \\
\hline
\end{tabular}

* Standard error is based on the inverse Hessian.

† Standard error is based on bootstrapping.

\section{D.2.2 Forebay and Dam Passage}

Table D.10. Forebay Virtual Release Detection and Survival Rates for Juvenile Steelhead

\section{Survival Detail:}

\begin{tabular}{|l|c|c|c|c|}
\hline & \multicolumn{2}{|c|}{ CR236.0 to CR153.0 } & \multicolumn{2}{c|}{ CR153.0 to CR113.0 } \\
\hline & Estimate & s.e.t & Estimate & s.e. $^{*}$ \\
\hline Steelhead - All Upstream Sit & 0.9442 & 0.004326 & 0.9906 & 0.002525 \\
\hline
\end{tabular}

\section{Capture Detail:}

\begin{tabular}{|l|c|c|c|c|c|c|}
\hline & \multicolumn{2}{|c|}{ CR153.0 } & \multicolumn{2}{c|}{ CR113.0 } & \multicolumn{2}{c|}{ CR086.2 Survival ${ }^{*}$ Capture } \\
\hline & Estimate & s.e. $^{*}$ & Estimate & s.e. $^{*}$ & Estimate & s.e. $^{*}$ \\
\hline Steelhead - All Upstream Sit & 0.7588 & 0.007642 & 0.9273 & 0.004785 & 0.9354 & 0.004567 \\
\hline
\end{tabular}

* Standard error is based on the inverse Hessian.

† Standard error is based on bootstrapping. 


\section{D.2.3 B1 Sluiceway Passage}

Table D.11. B1 Sluiceway Virtual Release Detection and Survival Rates for Juvenile Steelhead Survival Detail:

\begin{tabular}{|l|c|c|c|c|}
\hline & \multicolumn{2}{|c|}{ CR234.0 to CR153.0 } & \multicolumn{2}{l|}{ CR153.0 to CR113.0 } \\
\hline & Estimate & s.e.t & Estimate & s.e. $^{*}$ \\
\hline Steelhead - All Upstream Sit & 0.9629 & 0.025966 & 0.9695 & 0.026130 \\
\hline
\end{tabular}

\section{Capture Detail:}

\begin{tabular}{|l|c|c|c|c|c|c|}
\hline & \multicolumn{2}{|c|}{ CR153.0 } & \multicolumn{2}{c|}{ CR113.0 } & \multicolumn{2}{c|}{ CR086.2 Survival ${ }^{*}$ Capture $^{*}$} \\
\hline & Estimate & s.e. $^{*}$ & Estimate & s.e. $^{*}$ & Estimate & s.e. $^{*}$ \\
\hline Steelhead - All Upstream Sit & 0.7027 & 0.053133 & 0.9000 & 0.035857 & 0.9407 & 0.028960 \\
\hline
\end{tabular}

* Standard error is based on the inverse Hessian.

$\dagger$ Standard error is based on bootstrapping.

\section{D.2.4 B1 Turbine Passage}

Table D.12. B1 Turbine Virtual Release Detection and Survival Rates for Juvenile Steelhead Survival Detail:

\begin{tabular}{|l|c|c|c|c|}
\hline \hline & \multicolumn{2}{|c|}{ CR234.0 to CR153.0 } & \multicolumn{2}{c|}{ CR153.0 to CR113.0 } \\
\hline & Estimate & s.e.† & Estimate & s.e. \\
\hline Steelhead - All Upstream Sit & 0.9001 & 0.028439 & 1.0000 & 0.000000 \\
\hline
\end{tabular}

\section{Capture Detail:}

\begin{tabular}{|l|c|c|c|c|c|c|}
\hline & \multicolumn{2}{|c|}{ CR153.0 } & \multicolumn{2}{c|}{ CR113.0 } & \multicolumn{2}{c|}{ CR086.2 Survival*Capture } \\
\hline & Estimate & s.e. ${ }^{*}$ & Estimate & s.e. ${ }^{*}$ & Estimate & s.e. $^{*}$ \\
\hline Steelhead - All Upstream Sit & 0.6142 & 0.047761 & 0.9025 & 0.029280 & 0.9605 & 0.019550 \\
\hline
\end{tabular}

* Standard error is based on the inverse Hessian.

$\dagger$ Standard error is based on bootstrapping. 


\section{D.2.5 Spillway Passage}

Table D.13. Bonneville Spillway Virtual Release Detection and Survival Rates for Juvenile Steelhead Survival Detail:

\begin{tabular}{|l|c|c|c|c|}
\hline & \multicolumn{2}{|c|}{ CR234.0 to CR153.0 } & \multicolumn{2}{l|}{ CR153.0 to CR113.0 } \\
\hline & Estimate & s.e.t & Estimate & s.e. \\
\hline Steelhead - All Upstream Sit & 0.9389 & 0.006932 & 0.9884 & 0.004274 \\
\hline
\end{tabular}

\section{Capture Detail:}

\begin{tabular}{|l|c|c|c|c|c|c|}
\hline \hline & \multicolumn{2}{|c|}{ CR153.0 } & \multicolumn{2}{c|}{ CR113.0 } & CR086.2 Survival ${ }^{*}$ Capture \\
\hline & Estimate & s.e. $^{*}$ & Estimate & s.e. $^{*}$ & Estimate & s.e. $^{*}$ \\
\hline Steelhead - All Upstream Sit & 0.7651 & 0.011962 & 0.9261 & 0.007626 & 0.9329 & 0.007346 \\
\hline
\end{tabular}

* Standard error is based on the inverse Hessian.

$\dagger$ Standard error is based on bootstrapping.

\section{D.2.6 B2CC Passage}

Table D.14. B2CC Passage Detection and Survival Rates for Juvenile Steelhead

\section{Survival Detail:}

\begin{tabular}{|l|c|c|c|c|}
\hline \hline & \multicolumn{2}{|c|}{ CR234.0 to CR153.0 } & \multicolumn{2}{c|}{ CR153.0 to CR113.0 } \\
\hline & Estimate & s.e.† & Estimate & s.e. \\
\hline Steelhead - All Upstream Sit & 0.9751 & 0.005422 & 0.9943 & 0.003747 \\
\hline
\end{tabular}

\section{Capture Detail:}

\begin{tabular}{|l|c|c|c|c|c||c|}
\hline \hline & \multicolumn{2}{|c|}{ CR153.0 } & \multicolumn{2}{c|}{ CR113.0 } & \multicolumn{2}{c|}{ CR086.2 Survival ${ }^{*}$ Capture } \\
\hline & Estimate & s.e. & Estimate & s.e. $^{*}$ & Estimate $^{\text {s.e. }}$ & \\
\hline Steelhead - All Upstream Sit & 0.7671 & 0.013419 & 0.9368 & 0.007960 & 0.9383 & 0.007909 \\
\hline
\end{tabular}

* Standard error is based on the inverse Hessian.

† Standard error is based on bootstrapping. 


\section{D.2.7 B2 JBS Passage}

Table D.15. B2 JBS Passage Detection and Survival Rates for Juvenile Steelhead

\section{Survival Detail:}

\begin{tabular}{|l|c|c|c|c|}
\hline & \multicolumn{2}{|c|}{ CR234.0 to CR153.0 } & CR153.0 to CR113.0 \\
\hline & Estimate & s.e.t & Estimate & s.e. \\
\hline Steelhead - All Upstream Sit & 0.9784 & 0.011221 & 1.0000 & 0.000000 \\
\hline
\end{tabular}

\section{Capture Detail:}

\begin{tabular}{|l|c|c|c|c|c|c|}
\hline & \multicolumn{2}{|c|}{ CR153.0 } & \multicolumn{2}{c|}{ CR113.0 } & CR086.2 Survival ${ }^{*}$ Capture $^{*}$ \\
\hline & Estimate & s.e. & Estimate & s.e. & Estimate & s.e. $^{*}$ \\
\hline Steelhead - All Upstream Sit & 0.7876 & 0.029420 & 0.9062 & 0.021043 & 0.9427 & 0.016914 \\
\hline
\end{tabular}

* Standard error is based on the inverse Hessian.

† Standard error is based on bootstrapping.

\section{D.2.8 B2 Turbine Passage}

Table D.16. B2 Turbine Passage Detection and Survival Rates for Juvenile Steelhead

\section{Survival Detail:}

\begin{tabular}{|l|c|c|c|c|}
\hline \hline & \multicolumn{2}{|c|}{ CR234.0 to CR153.0 } & \multicolumn{2}{c|}{ CR153.0 to CR113.0 } \\
\hline & Estimate & s.e.† & Estimate & s.e. \\
\hline Steelhead - All Upstream Sit & 0.9111 & 0.012548 & 0.9824 & 0.007666 \\
\hline
\end{tabular}

\section{Capture Detail:}

\begin{tabular}{|l|c|c|c|c|c|c|}
\hline \hline & \multicolumn{2}{|c|}{ CR153.0 } & \multicolumn{2}{c|}{ CR113.0 } & \multicolumn{2}{c|}{ CR086.2 Survival*Capture } \\
\hline & Estimate & s.e. & Estimate & s.e. & Estimate & s.e. $^{*}$ \\
\hline Steelhead - All Upstream Sit & 0.7529 & 0.019098 & 0.9350 & 0.011287 & 0.9316 & 0.011578 \\
\hline
\end{tabular}

* Standard error is based on the inverse Hessian.

† Standard error is based on bootstrapping. 


\section{D.3 Capture Histories of Subyearling Chinook Salmon}

\section{D.3.1 Bonneville Dam Passage (V1 from TDA tailrace and Hood River Releases)}

Table D.17. Bonneville Dam Passage Detection and Survival Rates for Subyearling Chinook Salmon

Survival Detail:

\begin{tabular}{|l|c|c|c|c|}
\hline & \multicolumn{2}{|c|}{ CR234.0 to CR153.0 } & \multicolumn{2}{c|}{ CR153.0 to CR113.0 } \\
\hline & Estimate & s.e.† & Estimate & s.e. $^{*}$ \\
\hline Summer - TDA TR and Hood Riv & 0.9576 & 0.005475 & 0.9876 & 0.003658 \\
\hline
\end{tabular}

\section{Capture Detail:}

\begin{tabular}{|l|c|c|c|c|c|c|}
\hline & \multicolumn{2}{|c|}{ CR153.0 } & \multicolumn{2}{c|}{ CR113.0 } & \multicolumn{2}{c|}{ CR086.2 Survival ${ }^{*}$ Capture } \\
\hline & Estimate & s.e. & Estimate & s.e. ${ }^{*}$ & Estimate & s.e. $^{*}$ \\
\hline Summer - TDA TR and Hood Riv & 0.8691 & 0.009146 & 0.9525 & 0.005981 & 0.9262 & 0.007253 \\
\hline
\end{tabular}

* Standard error is based on the inverse Hessian.

† Standard error is based on bootstrapping.

\section{D.3.2 Bonneville Dam Passage under the 85 kcfs Day and 120 kcfs Night Spill Treatment (V1 from all upstream releases)}

Table D.18. Bonneville Dam Passage Detection and Survival Rates for Subyearling Chinook Salmon during the $85 \mathrm{kcfs}$ Day and $120 \mathrm{kcfs}$ Night Spill Treatment

Survival Detail:

\begin{tabular}{|l|c|c|c|c|}
\hline & \multicolumn{2}{|c|}{ CR234.0 to CR153.0 } & \multicolumn{2}{l|}{ CR153.0 to CR113.0 } \\
\hline & Estimate & s.e.† & Estimate & s.e. \\
\hline Summer - All Release Upstream & 0.9030 & 0.011085 & 0.9786 & 0.005945 \\
\hline
\end{tabular}

\section{Capture Detail:}

\begin{tabular}{|l|c|c|c|c|c|c|}
\hline & \multicolumn{2}{|c|}{ CR153.0 } & \multicolumn{2}{c|}{ CR113.0 } & \multicolumn{2}{c|}{ CR086.2 Survival ${ }^{*}$ Capture $^{*}$} \\
\hline & Estimate & s.e.* & Estimate & s.e. $^{*}$ & Estimate & s.e. $^{*}$ \\
\hline Summer - All Release Upstream & 0.9531 & 0.008355 & 0.9677 & 0.007107 & 0.9661 & 0.007265 \\
\hline
\end{tabular}

* Standard error is based on the inverse Hessian.

$\dagger$ Standard error is based on bootstrapping. 


\section{D.3.3 Bonneville Dam Passage Under the 24-h, 95-kcfs Spill Treatment (V1 from All Upstream Releases)}

Table D.19. Bonneville Dam Passage Detection and Survival Rates for Subyearling Chinook Salmon During the 24-h, 95-kcfs Spill Treatment

\section{Survival Detail:}

\begin{tabular}{|l|c|c|c|c|}
\hline & \multicolumn{2}{|c|}{ CR234.0 to CR153.0 } & \multicolumn{2}{c|}{ CR153.0 to CR113.0 } \\
\hline & Estimate & s.e.t & Estimate & s.e. \\
\hline Summer - All Release Upstrea & 0.9262 & 0.008931 & 0.9663 & 0.006584 \\
\hline
\end{tabular}

\section{Capture Detail:}

\begin{tabular}{|l|c|c|c|c|c|c|}
\hline \hline & \multicolumn{2}{|c|}{ CR153.0 } & \multicolumn{2}{c|}{ CR113.0 } & \multicolumn{2}{c|}{ CR086.2 Survival ${ }^{*}$ Capture $^{*}$} \\
\hline & Estimate & s.e. $^{*}$ & Estimate & s.e. & Estimate & s.e. $^{*}$ \\
\hline Summer - All Release Upstrea & 0.9363 & 0.008627 & 0.9627 & 0.006792 & 0.9702 & 0.006119 \\
\hline
\end{tabular}

* Standard error is based on the inverse Hessian.

† Standard error is based on bootstrapping.

\section{D.3.4 Forebay and Dam Passage}

Table D.20. Forebay Virtual Release Detection and Survival Rates for Subyearling Chinook Salmon

\section{Survival Detail:}

\begin{tabular}{|l|c|c|c|c|}
\hline & \multicolumn{2}{|c|}{ CR236.0 to CR153.0 } & \multicolumn{2}{c|}{ CR153.0 to CR113.0 } \\
\hline & Estimate & s.e.t & Estimate & s.e.* \\
\hline Summer - All Release Upstrea & 0.9413 & 0.004082 & 0.9842 & 0.002536 \\
\hline
\end{tabular}

\section{Capture Detail:}

\begin{tabular}{|l|c|c|c|c|c|c|}
\hline & \multicolumn{2}{|c|}{ CR153.0 } & \multicolumn{2}{c|}{ CR113.0 } & \multicolumn{2}{c|}{ CR086.2 Survival ${ }^{*}$ Capture } \\
\hline & Estimate & s.e. & Estimate & s.e. & Estimate & s.e. $^{*}$ \\
\hline Summer - All Release Upstrea & 0.8601 & 0.005918 & 0.9539 & 0.003713 & 0.9246 & 0.004603 \\
\hline
\end{tabular}

* Standard error is based on the inverse Hessian.

† Standard error is based on bootstrapping. 


\section{D.3.5 B1 Sluiceway Passage}

Table D.21. B1 Sluiceway Virtual Release Detection and Survival Rates for Subyearling Chinook Salmon

\section{Survival Detail:}

\begin{tabular}{|l|c|c|c|c|}
\hline & \multicolumn{2}{|c|}{ CR234.0 to CR153.0 } & \multicolumn{2}{c|}{ CR153.0 to CR113.0 } \\
\hline & Estimate & s.e.† & Estimate & s.e. \\
\hline Summer - All Release Upstrea & 0.9424 & 0.017319 & 0.9808 & 0.012890 \\
\hline
\end{tabular}

\section{Capture Detail:}

\begin{tabular}{|l|c|c|c|c|c|c|}
\hline \hline & \multicolumn{2}{|c|}{ CR153.0 } & \multicolumn{2}{c|}{ CR113.0 } & \multicolumn{2}{c|}{ CR086.2 Survival ${ }^{*}$ Capture } \\
\hline & Estimate & s.e. & Estimate & s.e. $^{*}$ & Estimate & s.e. $^{*}$ \\
\hline Summer - All Release Upstrea & 0.8500 & 0.026615 & 0.9329 & 0.019533 & 0.9053 & 0.022520 \\
\hline
\end{tabular}

* Standard error is based on the inverse Hessian.

† Standard error is based on bootstrapping.

\section{D.3.6 B1 Turbine Passage}

Table D.22. B1 Turbine Virtual Release Detection and Survival Rates for Subyearling Chinook Salmon Survival Detail:

\begin{tabular}{|l|c|c|c|c|}
\hline & \multicolumn{2}{|c|}{ CR234.0 to CR153.0 } & \multicolumn{2}{c|}{ CR153.0 to CR113.0 } \\
\hline & Estimate & s.e.† & Estimate & s.e. \\
\hline Summer - All Release Upstrea & 0.9671 & 0.008108 & 0.9831 & 0.006876 \\
\hline
\end{tabular}

\section{Capture Detail:}

\begin{tabular}{|l|c|c|c|c|c|c|}
\hline \hline & \multicolumn{2}{|c|}{ CR153.0 } & \multicolumn{2}{c|}{ CR113.0 } & \multicolumn{2}{c|}{ CR086.2 Survival ${ }^{*}$ Capture } \\
\hline & Estimate & s.e. & Estimate & s.e. & Estimate $^{*}$ s.e. $^{*}$ \\
\hline Summer - All Release Upstrea & 0.7974 & 0.017329 & 0.9649 & 0.008368 & 0.8964 & 0.013355 \\
\hline
\end{tabular}

* Standard error is based on the inverse Hessian.

† Standard error is based on bootstrapping. 


\section{D.3.7 Spillway Passage}

Table D.23. Bonneville Spillway Virtual Release Detection and Survival Rates for Subyearling Chinook Salmon

\section{Survival Detail:}

\begin{tabular}{|l|c|c|c|c|}
\hline & \multicolumn{2}{|c|}{ CR234.0 to CR153.0 } & \multicolumn{2}{c|}{ CR153.0 to CR113.0 } \\
\hline & Estimate & s.e.† & Estimate & s.e.* \\
\hline Summer - All Release Upstrea & 0.9304 & 0.006196 & 0.9833 & 0.003817 \\
\hline
\end{tabular}

\section{Capture Detail:}

\begin{tabular}{|l|c|c|c|c|c|c|}
\hline & \multicolumn{2}{|c|}{ CR153.0 } & \multicolumn{2}{c|}{ CR113.0 } & \multicolumn{2}{c|}{ CR086.2 Survival*Capture } \\
\hline & Estimate & s.e.* & Estimate & s.e.* & Estimate & s.e.* $^{*}$ \\
\hline Summer - All Release Upstrea & 0.8679 & 0.008391 & 0.9488 & 0.005687 & 0.9194 & 0.006912 \\
\hline
\end{tabular}

* Standard error is based on the inverse Hessian.

† Standard error is based on bootstrapping.

\section{D.3.8 B2CC Passage}

Table D.24. B2CC Passage Detection and Survival Rates for Subyearling Chinook Salmon

\section{Survival Detail:}

\begin{tabular}{|l|c|c|c|c|}
\hline \hline & \multicolumn{2}{|c|}{ CR234.0 to CR153.0 } & \multicolumn{2}{c|}{ CR153.0 to CR113.0 } \\
\hline & Estimate & s.e.† & Estimate & s.e.* $^{*}$ \\
\hline Summer - All Release Upstrea & 0.9704 & 0.010104 & 0.9755 & 0.009666 \\
\hline
\end{tabular}

\section{Capture Detail:}

\begin{tabular}{|l|c|c|c|c|c|c|}
\hline \hline & \multicolumn{2}{|c|}{ CR153.0 } & \multicolumn{2}{c|}{ CR113.0 } & \multicolumn{2}{c|}{ CR086.2 Survival ${ }^{*}$ Capture } \\
\hline & Estimate & s.e. & Estimate & s.e. & Estimate $^{*}$ s.e. $^{*}$ \\
\hline Summer - All Release Upstrea & 0.8980 & 0.017654 & 0.9579 & 0.011896 & 0.9681 & 0.010467 \\
\hline
\end{tabular}

* Standard error is based on the inverse Hessian.

† Standard error is based on bootstrapping. 


\section{D.3.9 B2 JBS Passage}

Table D.25. B2 JBS Passage Detection and Survival Rates for Subyearling Chinook Salmon Survival Detail:

\begin{tabular}{|l|c|c|c|c|}
\hline & \multicolumn{2}{|c|}{ CR234.0 to CR153.0 } & \multicolumn{2}{c|}{ CR153.0 to CR113.0 } \\
\hline & Estimate & s.e.† & Estimate & s.e.* \\
\hline Summer - All Release Upstrea & 0.9759 & 0.015447 & 0.9894 & 0.015611 \\
\hline
\end{tabular}

\section{Capture Detail:}

\begin{tabular}{|l|c|c|c|c|c|c|}
\hline & \multicolumn{2}{|c|}{ CR153.0 } & \multicolumn{2}{c|}{ CR113.0 } & \multicolumn{2}{c|}{ CR086.2 Survival ${ }^{*}$ Capture $^{*}$} \\
\hline & Estimate & s.e. $^{*}$ & Estimate & s.e. $^{*}$ & Estimate & s.e. $^{*}$ \\
\hline Summer - All Release Upstrea & 0.8692 & 0.032601 & 0.9063 & 0.029749 & 0.8878 & 0.031887 \\
\hline
\end{tabular}

* Standard error is based on the inverse Hessian.

† Standard error is based on bootstrapping.

\section{D.3.10 B2 Turbine Passage}

Table D.26. B2 Turbine Passage Detection and Survival Rates for Subyearling Chinook Salmon Survival Detail:

\begin{tabular}{|l|c|c|c|c|}
\hline & \multicolumn{2}{|c|}{ CR234.0 to CR153.0 } & \multicolumn{2}{c|}{ CR153.0 to CR113.0 } \\
\hline & Estimate & s.e.† & Estimate & s.e.* \\
\hline Summer - All Release Upstrea & 0.9363 & 0.011736 & 0.9983 & 0.002835 \\
\hline
\end{tabular}

\section{Capture Detail:}

\begin{tabular}{|l|c|c|c|c|c|c|}
\hline \hline & \multicolumn{2}{|c|}{ CR153.0 } & \multicolumn{2}{c|}{ CR113.0 } & \multicolumn{2}{c|}{ CR086.2 Survival ${ }^{*}$ Capture } \\
\hline & Estimate & s.e.* & Estimate & s.e. & Estimate $^{*}$ s.e. $^{*}$ \\
\hline Summer - All Release Upstrea & 0.8725 & 0.016510 & 0.9719 & 0.008341 & 0.9597 & 0.009870 \\
\hline
\end{tabular}

* Standard error is based on the inverse Hessian.

$\uparrow$ Standard error is based on bootstrapping. 
Appendix E

Assessment of Survival Model Assumptions 


\section{Appendix E}

\section{Assessment of Survival Model Assumptions}

The assessment of assumptions covers fish size distribution, handling mortality and tag shedding, taglife corrections, arrival distributions, and tagger effects. Downstream mixing was not an issue with the Bonneville Dam (BON) study in 2010 because there were no downstream releases of fish. Our use of B2CC-passage survival estimates as a reference release was assured to have downstream mixing because dam-passed and B2CC-passed fish arrived at all hours of the day from the two most upstream release locations.

\section{E.1 Fish Size Distribution}

Comparison of acoustic-tagged fish with run-of-river (ROR) fish sampled at John Day Dam (JDA) through the Smolt Monitoring Program shows that the length frequency distributions were generally well matched for yearling Chinook salmon (CH1) and juvenile steelhead (STH) (Figure E.1). For STH, the upper size limit for the tagged fish was $260 \mathrm{~mm}$, and none of the very large fish (>260 mm) were tagged. Median length for acoustic-tagged CH1 was $153 \mathrm{~mm}$. For STH smolts, the median length of the tagged fish was $214 \mathrm{~mm}$. The median length of tagged $\mathrm{CH} 1$ and STH remained stable throughout the study (Skalski et al. 2010a).

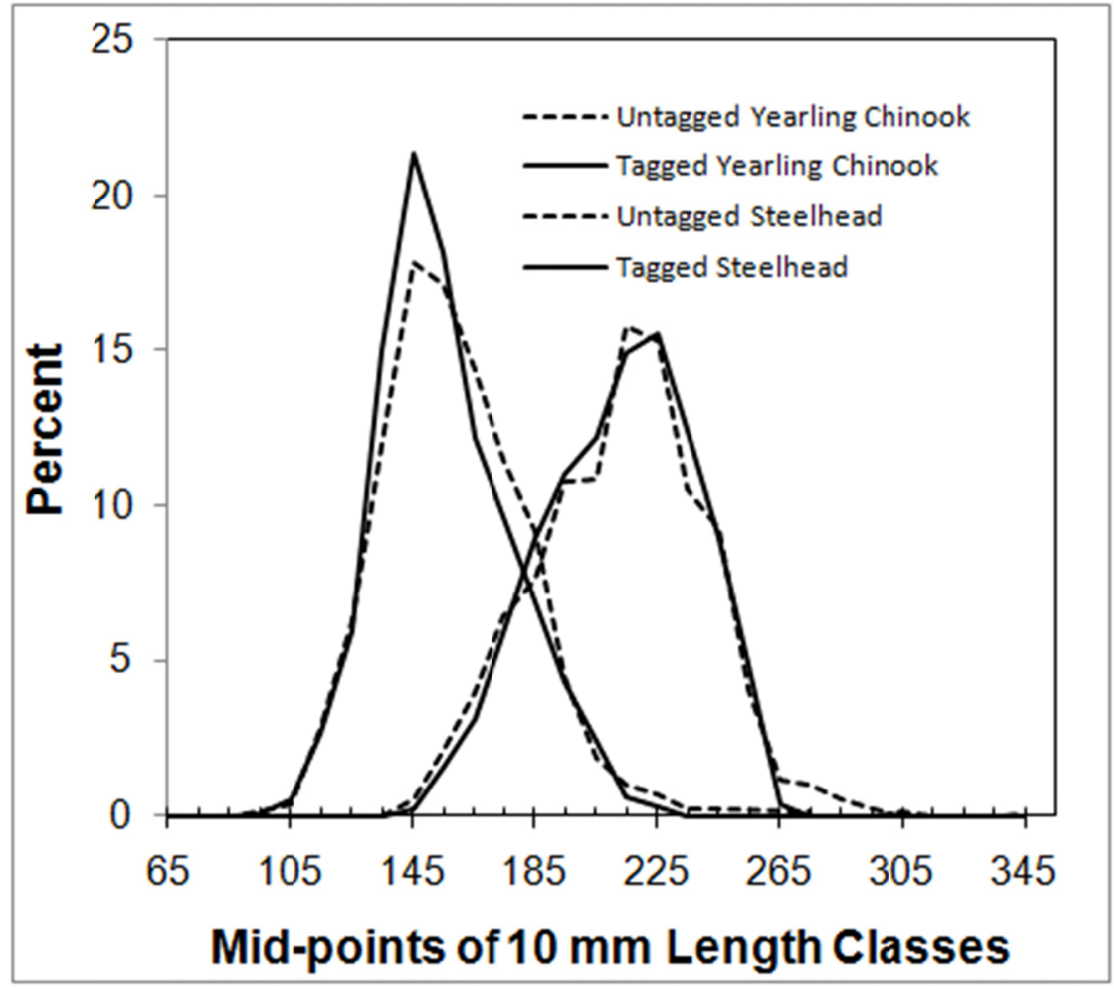

Figure E.1. Comparison of Length Frequency Distributions of Tagged and Untagged Fish Passing the John Day Dam Smolt Monitoring Facility 
Comparison of acoustic-tagged fish with ROR fish sampled at JDA through the Smolt Monitoring Program shows that the length frequency distributions were generally well-matched for subyearling Chinook salmon (CH0) (Figure E.2). The tagged fish had less representation in the 95- to 100-mm and 105- to 110 -mm categories than the ROR fish because no fish $<95 \mathrm{~mm}$ were tagged. The length distributions for the three $\mathrm{CH} 0$ releases were quite similar, and the median length of tagged fish across the course of the study remained stable (Skalski et al. 2010b).

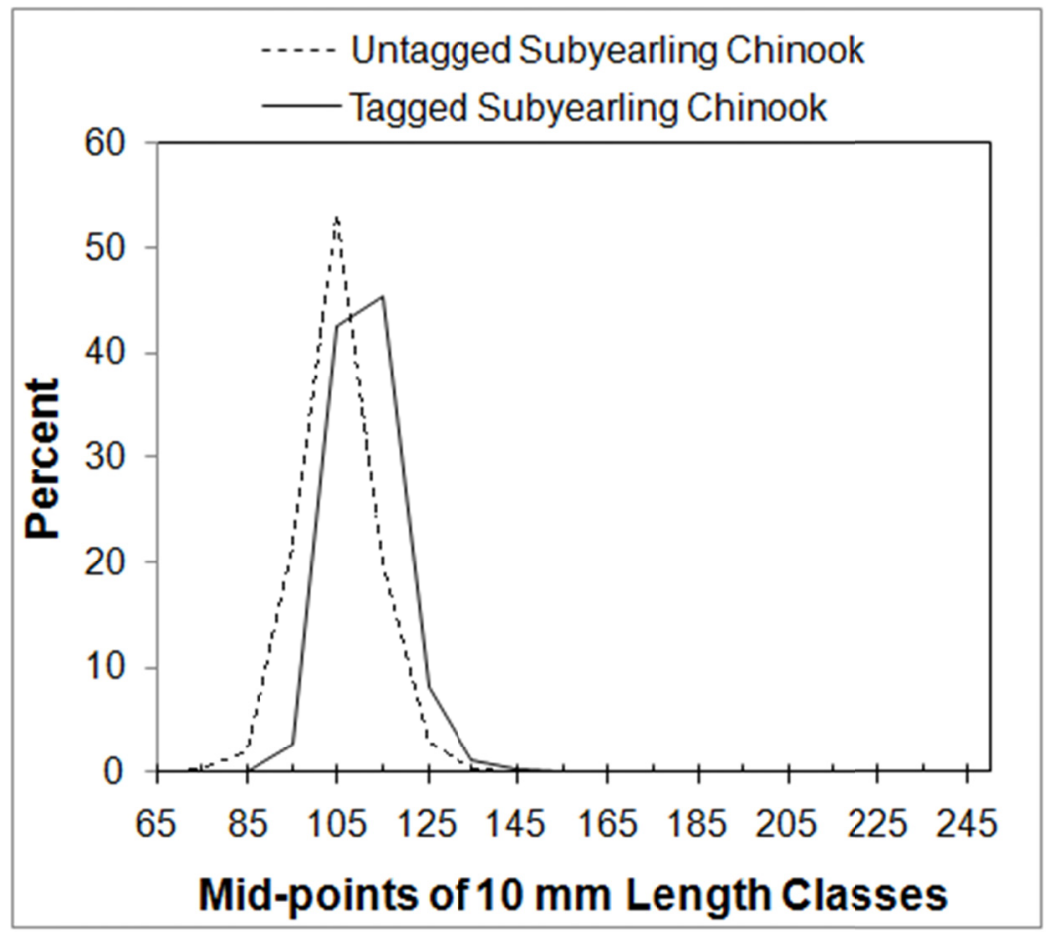

Figure E.2. Relative Length Frequency Distributions of Tagged and Untagged Subyearling Chinook in John Day Smolt Monitoring Facility Samples in Summer 2010

\section{E.2 Handling Mortality and Tag Shedding}

Fish were held for $24 \mathrm{~h}$ prior to release. The 24 -h tagging mortality was $0.10 \%$ for $\mathrm{CH} 1,0.05 \%$ for juvenile STH, and $0.22 \%$ for $\mathrm{CH}$. No tags were shed during the 24 -h holding period in either season.

\section{E.3 Tag-Life Corrections}

For the spring 2010 study, mean tag life $(n=49)$ was 32.73 days. The earliest tag failure was at 7.8 days and the longest at 39.6 days (Figure E.3). The failure-time data for the acoustic tags was fit to a four-parameter vitality model of $\mathrm{Li}$ and Anderson (2009). The maximum likelihood estimates for the four model parameters were $\hat{r}=0.02963, \hat{s}=-5.59145 \times 10^{-9}, \hat{k}=0.00173$, and $\hat{u}=0.05730$. This tag-life survivorship model was subsequently used to estimate the probabilities of tag failure and provide tag-lifeadjusted estimates of smolt survival. 


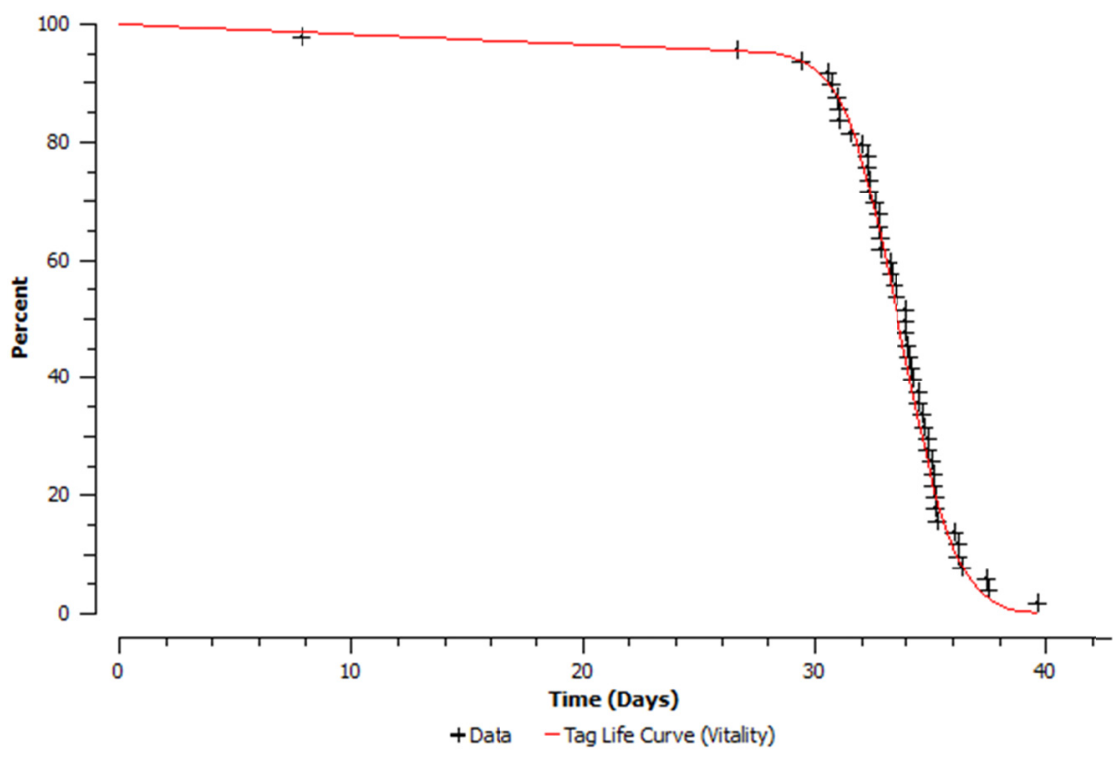

Figure E.3. Individual Failure Times for the $n=49$ Acoustic Tags Used in the Tag-Life Study, Along with the Fitted Four-Parameter Vitality Model of Li and Anderson (2009) for Spring 2010

For the summer study, mean tag life $(n=50)$ was 35.54 days. The earliest tag failure was at 31.27 days and the longest at 40.13 days (Figure E.4). The failure-time data for the acoustic tags was fit to a four-parameter vitality model of Li and Anderson (2009). The maximum likelihood estimates for the four model parameters were $\hat{r}=0.028261, \hat{s}=-2.91111 \times 10^{-9}, \hat{k}=0$, and $\hat{u}=0.058789$ (Figure C.6). This tag-life survivorship model was subsequently used to estimate the probabilities of tag failure and provide tag-life-adjusted estimates of smolt survival.

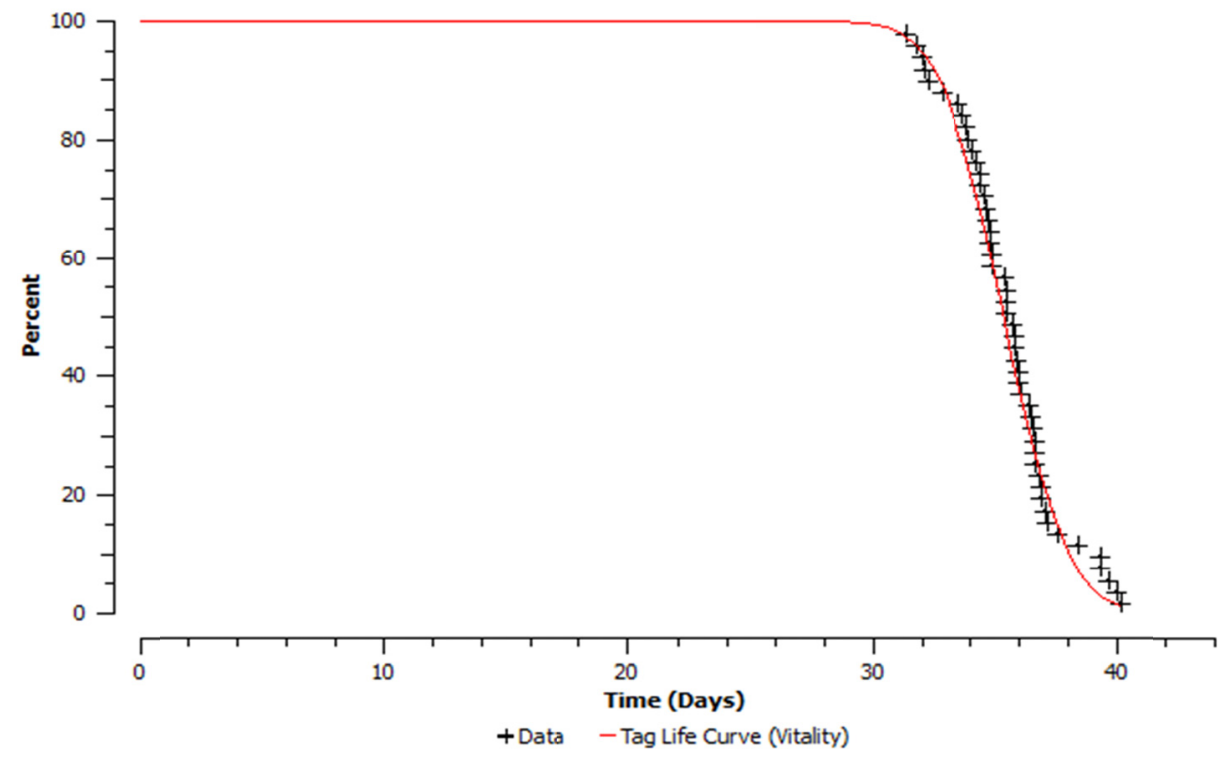

Figure E.4. Individual Failure Times for the $n=49$ Acoustic Tags Used in the Tag-Life Study, Along with the Fitted Four-Parameter Vitality Model of Li and Anderson (2009) for Summer 2010 


\section{E.4 Arrival Distributions at Downstream Arrays}

The estimated probability an acoustic tag was active when fish arrived at a downstream detection array depends on the tag-life curve and the distribution of observed travel times. These probabilities were calculated by integrating the tag survivorship curves (Figures E.3 and E.4) over the observed distribution of fish arrival times (i.e., time from tag activation to arrival) for the three tagged fish stocks separately. The estimated probabilities of tag activation for the various release groups at the different detection arrays always exceeded 0.98. The tag-life-adjusted survival estimates were based on the estimated probabilities of tag activation reported in Table E.1, E.2, and E.3 for the respective runs of fish studied.

The last distinct detection array used in the survival analysis was rkm 86.2 (Figure 2.12). Plots of the arrival distributions of the three release groups (i.e., $V_{1}, R_{2}$, and $R_{3}$ ) to that array indicate the $\mathrm{CH} 1$ (Figure E.5), STH (E.6), and CH0 (Figure E.7) should have arrived well before tag failure became problematic. Tag-life adjustments to survival estimates would be incomplete if fish have arrival times beyond the range of observed tag lives.

Table E.1. Estimated Probabilities $(L)$ of an Acoustic Tag Being Active When a Yearling Chinook Salmon Arrived at a Detection Array Used in Estimating Dam-Passage Survival at Bonneville Dam in 2010. For the $V_{1}$ release, the $L$ values are the conditional probability a tag is active, given it was active at the time the group was formed at the detection array at rkm 234. (Standard errors are in parentheses.)

\begin{tabular}{|c|c|c|c|c|c|c|}
\hline \multicolumn{3}{|c|}{ Release } & \multicolumn{4}{c|}{ Detection Sites } \\
\hline Group & Site & Bin & D0: CR234.0 & D1: CR153.0 & D2: CR113.0 & D3: CR086.2 \\
\hline V1 & Yearling Chinook - All Upstr & 1 & $0.9878(0.006508)$ & $0.9981(0.001025)$ & $0.9972(0.001486)$ & $0.9967(0.001800)$ \\
\hline
\end{tabular}

Table E.2. Estimated Probabilities $(L)$ of an Acoustic Tag Being Active When a Steelhead Arrived at a Detection Array Used in Estimating Dam-Passage Survival at Bonneville Dam in 2010. For the $V_{1}$ release, the $L$ values are the conditional probability a tag is active, given it was active at the time the group was formed at the detection array at rkm 234. (Standard errors are in parentheses.)

\begin{tabular}{|c|c|c|c|c|c|c|}
\hline \multicolumn{3}{|c|}{ Release } & \multicolumn{4}{c|}{ Detection Sites } \\
\hline Group & Site & Bin & D0: CR234.0 & D1: CR153.0 & D2: CR113.0 & D3: CR086.2 \\
\hline V1 & Steelhead - All Upstream Sit & 1 & $0.9872(0.007080)$ & $0.9981(0.001089)$ & $0.9972(0.001577)$ & $0.9967(0.001861)$ \\
\hline
\end{tabular}

Table E.3. Estimated Probabilities $(L)$ of an Acoustic Tag Being Active When a Subyearling Chinook Salmon Arrived at a Detection Array Used in Estimating Dam-Passage Survival at Bonneville Dam in 2010. For the $V_{1}$ release, the $L$ values are the conditional probability a tag is active, given it was active at the time the group was formed at the detection array at rkm 234. (Standard errors are in parentheses.)

\begin{tabular}{|c|c|c|c|c|c|c|}
\hline \hline \multicolumn{2}{|c|}{ Release } & \multicolumn{4}{c|}{ Detection Sites } \\
\hline Group & Site & Bin & D0: CR234.0 & D1: CR153.0 & D2: CR113.0 & D3: CR086.2 \\
\hline V1 & Summer - All Release Upstrea & 1 & $1.0000(0.002390)$ & $1.0000(0.000690)$ & $1.0000(0.000993)$ & $1.0000(0.001207)$ \\
\hline
\end{tabular}




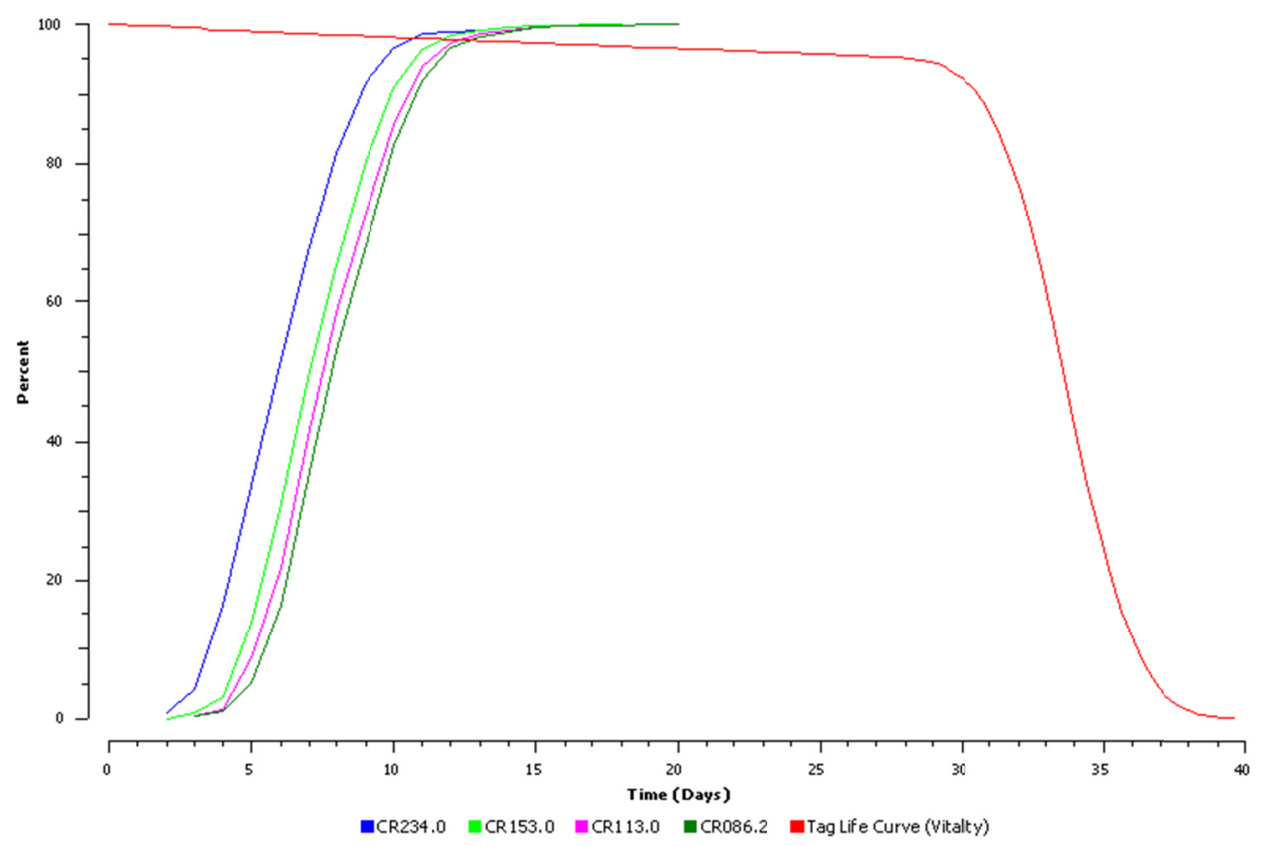

Figure E.5. Fish Passage Plots (expressed as percentages) of Downstream Arrival Timing for All Yearling Chinook Salmon Release $V_{1}$ at Detection Arrays Located at Rkm 234, Rkm 153, Rkm 113, and Rkm 86.2 Versus Tag-Life Curve. All times adjusted relative to the release time of $V_{1}$. The distributions averaged over all release groups.

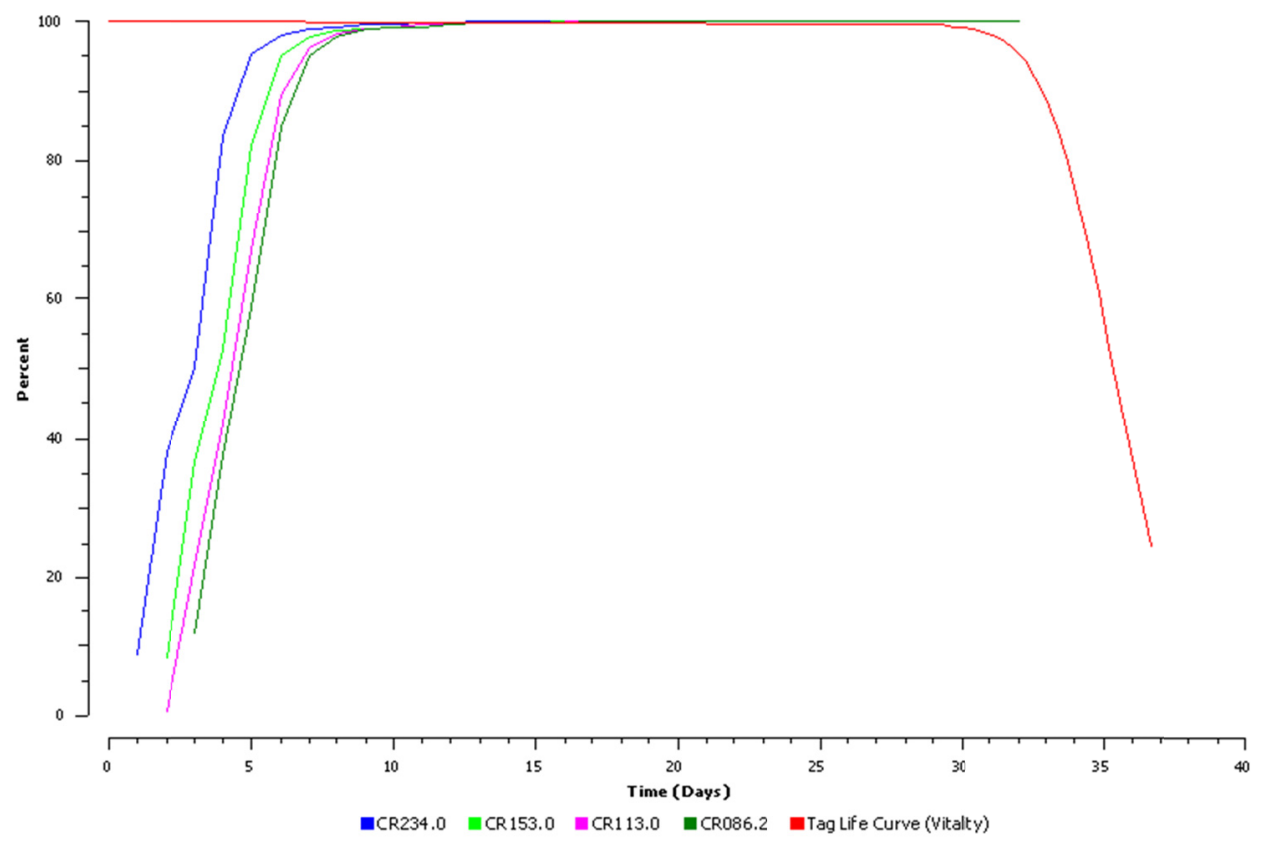

Figure E.6. Fish Passage Plots (expressed as percentages) of Downstream Arriving Timing for All Steelhead Release, $V_{1}$ at Detection Arrays Located at Rkm 234, Rkm 153, Rkm 113, and Rkm 86.2 Versus Tag-Life Curve. All times adjusted relative to the release time of $V_{1}$. The distributions averaged over all release groups. 


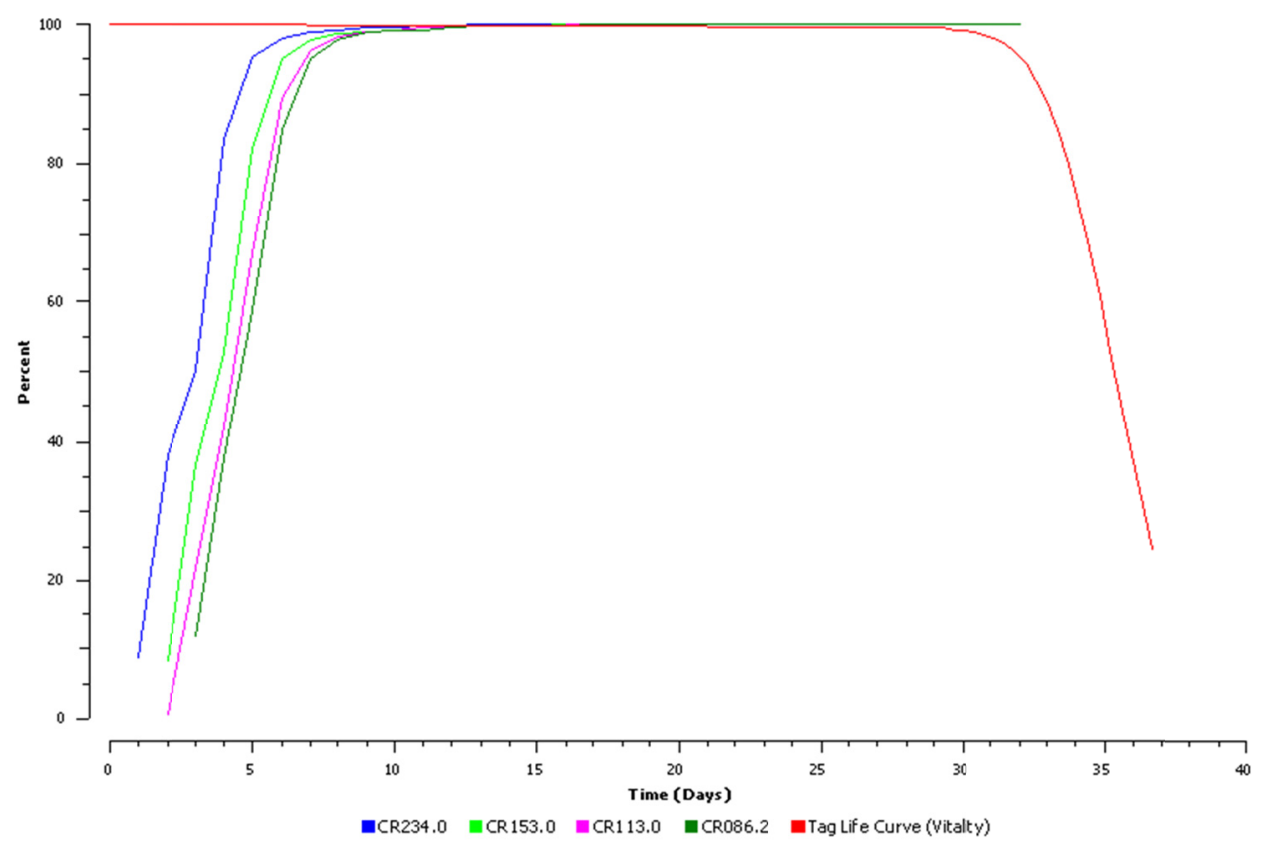

Figure E.7. Fish Passage Plots (expressed as percentages) of Downstream Arriving Timing for All Subyearling Chinook Salmon Release $V_{1}$ at Detection Arrays Located at Rkm 234, Rkm 153, Rkm 113, and Rkm 86.2 Versus Tag-Life Curve. All times adjusted relative to the release time of $V_{1}$. The distributions averaged over all release groups.

\section{E.5 Tagger Effects}

Having various fish handlers tag the same proportions of fish for release at each of the release sites helped minimize but did not necessarily eliminate handling effects in the survival study. The study was therefore designed to balance tagger effort across locations. Implementation produced near-perfect balance for the CH1 (Table E.3), STH (Table E.4), and CH0 (Table E.5) releases.

To further assess whether tagger effects may have occurred, reach survivals for the fish tagged by the different staff were calculated using the Cormack-Jolly-Seber single release-recapture model. For both CH1 (Table E.6) and STH (Table E.7), reach survivals were found to be homogeneous $(P>0.05)$ across all reaches examined. For this reason, all fish, regardless of fish tagger, were included in the survival analyses for $\mathrm{CH} 1$ and $\mathrm{STH}$.

For CH0, significant $(P<0.05)$ heterogeneity was detected (Table E.8). However, further examination indicated that seasonal trends in survival were confounding attempts to assess the presence of tagger effects using the $F$-tests because the effect of the various taggers was not evenly distributed across the course of the study. Fish tagged by tagger $\mathrm{G}$ had lower survivals because that staff member only tagged fish towards the end of the season. Fish tagged by tagger B had very good survival because that staff member only tagged fish at the beginning of the study. The remaining taggers had fish with intermediate survivals because they tagged fish more or less across the breadth of the season. The fish tagged by different staff during the same time were examined; survivals were homogeneous with no obvious evidence of any tagger effect. Therefore, fish tagged by all taggers were included in the analysis for this report. 
Table E.4. Number of Yearling Chinook Salmon Tagged at Each Release Site by Tagger. Tagger effort was homogeneous $\left(P\left(\chi_{10}^{2} \geq 1.0336\right)=0.9998\right)$

\begin{tabular}{cccccccc}
\hline & \multicolumn{7}{c}{ Tagger } \\
\cline { 2 - 6 } Release Location & $\# 1$ & $\# 2$ & $\# 3$ & $\# 4$ & $\# 5$ & $\# 6$ & Total \\
\hline$R_{1}$ & 441 & 356 & 311 & 350 & 372 & 457 & $\mathbf{2 2 8 7}$ \\
$R_{2}$ & 149 & 123 & 110 & 129 & 124 & 161 & $\mathbf{7 9 6}$ \\
$R_{3}$ & 152 & 126 & 109 & 117 & 130 & 163 & $\mathbf{7 9 7}$ \\
\hline Total Tags & $\mathbf{7 4 2}$ & $\mathbf{6 0 5}$ & $\mathbf{5 3 0}$ & $\mathbf{5 9 6}$ & $\mathbf{6 2 6}$ & $\mathbf{7 8 1}$ & $\mathbf{3 8 8 0}$ \\
\hline
\end{tabular}

Table E.5. Number of Steelhead Tagged at Each Release Site by Tagger. Tagger effort was homogeneous $\left(P\left(\chi_{10}^{2} \geq 0.5851\right)=1.0000\right)$

\begin{tabular}{|c|c|c|c|c|c|c|c|}
\hline \multirow[b]{2}{*}{ Release Location } & \multicolumn{6}{|c|}{ Tagger } & \multirow[b]{2}{*}{ Total } \\
\hline & \#1 & \#2 & \#3 & \#4 & \#5 & \#6 & \\
\hline$R_{1}$ & 430 & 359 & 331 & 354 & 365 & 449 & 2288 \\
\hline$R_{2}$ & 155 & 124 & 114 & 126 & 125 & 155 & 799 \\
\hline$R_{3}$ & 157 & 121 & 112 & 126 & 126 & 156 & 798 \\
\hline Total Tags & 742 & 604 & 557 & 606 & 616 & 760 & 3885 \\
\hline
\end{tabular}

Table E.6. Number of Subyearling Chinook Salmon Tagged at Each Release Site by Tagger. Tagger effort was homogeneous $\left(P\left(\chi_{12}^{2} \geq 8.6496\right)=0.7325\right)$.

\begin{tabular}{ccccccccc}
\hline & \multicolumn{7}{c}{ Tagger } \\
\hline Release Location & $\mathrm{A}$ & $\mathrm{B}$ & $\mathrm{C}$ & $\mathrm{D}$ & $\mathrm{E}$ & $\mathrm{F}$ & $\mathrm{G}$ & Total \\
\hline$R_{1}$ & 436 & 489 & 463 & 454 & 171 & 369 & 467 & $\mathbf{2 , 8 4 9}$ \\
$R_{2}$ & 132 & 135 & 116 & 123 & 40 & 108 & 146 & $\mathbf{8 0 0}$ \\
$R_{3}$ & 131 & 133 & 128 & 119 & 35 & 115 & 139 & $\mathbf{8 0 0}$ \\
\hline Total Tags & $\mathbf{6 9 9}$ & $\mathbf{7 5 7}$ & $\mathbf{7 0 7}$ & $\mathbf{6 9 6}$ & $\mathbf{2 4 6}$ & $\mathbf{5 9 2}$ & $\mathbf{7 5 2}$ & $\mathbf{4 , 4 4 9}$ \\
\hline
\end{tabular}


Table E.7. Cormack-Jolly-Seber Estimates of Reach Survivals by Release Site and Tagger for Yearling Chinook Salmon Smolts. Standard errors in parentheses. $F$-tests below each release and reach test for homogeneity of survival across taggers. No tests were significant $(\alpha<0.05)$.

\begin{tabular}{|c|c|c|c|c|c|c|c|}
\hline \multirow[b]{2}{*}{$\begin{array}{l}\text { Release } \\
\text { Site }\end{array}$} & \multirow[b]{2}{*}{ Tagger } & \multicolumn{6}{|c|}{ Cormack-Jolly-Seber Survival } \\
\hline & & $\begin{array}{l}\text { Release to Rkm } \\
309\end{array}$ & $\mathrm{Rkm} 309$ to 275 & Rkm 275 to 234 & Rkm 234 to 153 & Rkm 153 to 113 & Rkm 113 to 86 \\
\hline \multirow{6}{*}{ 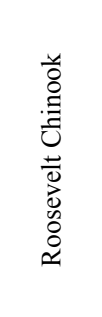 } & $\# 1$ & $0.8912(0.0148)$ & $0.9364(0.0123)$ & $0.9790(0.0076)$ & $0.9165(0.0147)$ & $0.9975(0.0034)$ & $1.0000(<0.0001)$ \\
\hline & $\# 2$ & $0.8934(0.0164)$ & $0.9527(0.0119)$ & $0.9910(0.0057)$ & $0.9512(0.0134)$ & $0.9790(0.0102)$ & $1.0000(<0.0001)$ \\
\hline & $\# 3$ & $0.8489(0.0203)$ & $0.9318(0.0155)$ & $0.9797(0.0090)$ & $0.9554(0.0135)$ & $0.9953(0.0054)$ & $1.0000(<0.0001)$ \\
\hline & $\# 4$ & $0.8943(0.0164)$ & $0.9457(0.0128)$ & $0.9767(0.0088)$ & $0.9383(0.0148)$ & $0.9789(0.0102)$ & $0.9917(0.0141)$ \\
\hline & $\# 5$ & $0.9140(0.0145)$ & $0.9382(0.0131)$ & $0.9906(0.0053)$ & $0.9215(0.0152)$ & $0.9985(0.0048)$ & $0.9899(0.0131)$ \\
\hline & $\# 6$ & $0.9059(0.0137)$ & $0.9348(0.0121)$ & $0.9798(0.0072)$ & $0.9282(0.0136)$ & $0.9880(0.0070)$ & $1.0000(0.0165)$ \\
\hline \multirow{9}{*}{ 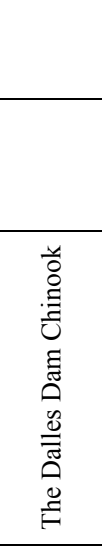 } & $F$-test & 1.9448 & 0.3597 & 0.7243 & 1.2466 & 1.5091 & 0.2137 \\
\hline & $P$-value & 0.0828 & 0.8763 & 0.6051 & 0.2840 & 0.1832 & 0.9569 \\
\hline & \multicolumn{3}{|r|}{$\begin{array}{c}\text { Release to Rkm } \\
275\end{array}$} & Rkm 275 to 234 & Rkm 234 to 153 & Rkm 153 to 113 & Rkm 113 to 86 \\
\hline & $\# 1$ & & $0.9731(0.0132)$ & $0.9798(0.0118)$ & $0.9295(0.0216)$ & $1.0000(0.0073)$ & $1.0000(<0.0001)$ \\
\hline & $\# 2$ & & $0.9756(0.0139)$ & $0.9750(0.0142)$ & $0.9403(0.0219)$ & $1.0000(<0.0001)$ & $1.0000(0.0260)$ \\
\hline & $\# 3$ & & $0.9909(0.0089)$ & $0.9821(0.0128)$ & $0.9534(0.0206)$ & $1.0000(<0.0001)$ & $0.9986(0.0403)$ \\
\hline & $\# 4$ & & $0.9690(0.0152)$ & $0.9760(0.0137)$ & $0.9275(0.0237)$ & $0.9916(0.0101)$ & $0.9933(0.0230)$ \\
\hline & $\# 5$ & & $0.9919(0.0079)$ & $0.9756(0.0139)$ & $0.9419(0.0214)$ & $1.0000(0.0145)$ & $0.9795(0.0180)$ \\
\hline & $\# 6$ & & $0.9813(0.0106)$ & $0.9943(0.0062)$ & $0.9568(0.0168)$ & $0.9925(0.0086)$ & $1.0000(<0.0001)$ \\
\hline \multicolumn{2}{|r|}{$F$-test } & & 0.6328 & 0.3480 & 0.3221 & 0.2312 & 0.1259 \\
\hline \multicolumn{2}{|r|}{$P$-value } & & 0.6747 & 0.8838 & 0.9000 & 0.9490 & 0.9866 \\
\hline \multicolumn{8}{|c|}{$\begin{array}{c}\text { Release to Rkm } \\
234\end{array}$} \\
\hline \multirow{6}{*}{ 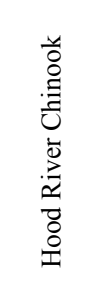 } & $\# 1$ & & & $0.9737(0.0130)$ & $0.9599(0.0162)$ & $1.0000(0.0083)$ & $1.0000(<0.0001)$ \\
\hline & $\# 2$ & & & $0.9921(0.0078)$ & $0.9710(0.0159)$ & $0.9821(0.0138)$ & $1.0000(<0.0001)$ \\
\hline & $\# 3$ & & & $0.9816(0.0128)$ & $0.9445(0.0223)$ & $1.0000(<0.0001)$ & $1.0000(<0.0001)$ \\
\hline & $\# 4$ & & & $0.9829(0.0119)$ & $0.9485(0.0207)$ & $1.0000(<0.0001)$ & $0.9841(0.0356)$ \\
\hline & $\# 5$ & & & $0.9923(0.0076)$ & $0.9473(0.0200)$ & $0.9928(0.0098)$ & $1.0000(0.0305)$ \\
\hline & $\# 6$ & & & $0.9945(0.0060)$ & $0.9510(0.0172)$ & $1.0000(<0.0001)$ & $0.9440(0.0242)$ \\
\hline \multicolumn{2}{|r|}{$F$-test } & & & 0.1386 & 0.2795 & 0.9024 & 0.6280 \\
\hline \multicolumn{2}{|r|}{$P$-value } & & & 0.9834 & 0.9246 & 0.4783 & 0.6784 \\
\hline
\end{tabular}


Table E.8. Cormack-Jolly-Seber Estimates of Reach Survivals by Release Site and Tagger for Steelhead Smolts. Standard errors in parentheses. $F$-tests below each release and reach test for homogeneity of survival across taggers. No tests were significant $(\alpha<0.05)$.

\begin{tabular}{|c|c|c|c|c|c|c|c|}
\hline \multirow[b]{2}{*}{$\begin{array}{l}\text { Release } \\
\text { Site }\end{array}$} & \multirow[b]{2}{*}{ Tagger } & \multicolumn{6}{|c|}{ Cormack-Jolly-Seber Survivals } \\
\hline & & $\begin{array}{l}\text { Release to Rkm } \\
309\end{array}$ & Rkm 309 to 275 & Rkm 275 to 234 & Rkm 234 to 153 & Rkm 153 to 113 & Rkm 113 to 86 \\
\hline \multirow{6}{*}{ 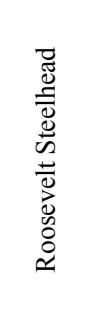 } & $\# 1$ & $0.8930(0.0149)$ & $0.9505(0.0111)$ & $0.9699(0.0089)$ & $0.9107(0.0153)$ & $0.9978(0.0041)$ & $1.0000(<0.0001)$ \\
\hline & $\# 2$ & $0.8831(0.0170)$ & $0.9621(0.0107)$ & $0.9671(0.0102)$ & $0.9131(0.0166)$ & $1.0000(0.0083)$ & $0.9869(0.0225)$ \\
\hline & $\# 3$ & $0.9063(0.0160)$ & $0.9600(0.0113)$ & $0.9831(0.0077)$ & $0.8978(0.0186)$ & $0.9824(0.0102)$ & $1.0000(<0.0001)$ \\
\hline & $\# 4$ & $0.8729(0.0177)$ & $0.9320(0.0143)$ & $0.9725(0.0097)$ & $0.9479(0.0149)$ & $0.9683(0.0134)$ & $0.9934(0.0254)$ \\
\hline & $\# 5$ & $0.9151(0.0146)$ & $0.9372(0.0133)$ & $0.9776(0.0084)$ & $0.9069(0.0172)$ & $0.9805(0.0105)$ & $0.9737(0.0208)$ \\
\hline & $\# 6$ & $0.9065(0.0137)$ & $0.9656(0.0090)$ & $0.9804(0.0072)$ & $0.9118(0.0149)$ & $0.9892(0.0076)$ & $0.9895(0.0239)$ \\
\hline \multirow{9}{*}{ 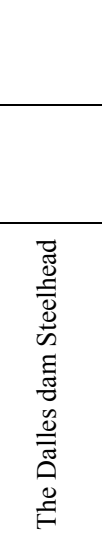 } & $F$-test & 1.0452 & 1.4044 & 0.5128 & 1.1099 & 1.5660 & 0.2701 \\
\hline & $P$-value & 0.3890 & 0.2192 & 0.7668 & 0.3525 & 0.1659 & 0.9297 \\
\hline & & & $\begin{array}{c}\text { Release to Rkm } \\
275\end{array}$ & Rkm 275 to 234 & Rkm 234 to 153 & Rkm 153 to 113 & Rkm 113 to 86 \\
\hline & $\# 1$ & & $0.9806(0.0110)$ & $0.9803(0.0113)$ & $0.9333(0.0205)$ & $1.0000(<0.0001)$ & $0.9967(0.0345)$ \\
\hline & $\# 2$ & & $0.9758(0.0138)$ & $0.9752(0.0141)$ & $0.9527(0.0205)$ & $0.9805(0.0151)$ & $0.9944(0.0206)$ \\
\hline & $\# 3$ & & $0.9912(0.0087)$ & $0.9734(0.0151)$ & $0.9478(0.0218)$ & $0.9902(0.0120)$ & $1.0000(<0.0001)$ \\
\hline & $\# 4$ & & $0.9920(0.0078)$ & $0.9840(0.0112)$ & $0.9843(0.0114)$ & $1.0000(0.0075)$ & $1.0000(<0.0001)$ \\
\hline & $\# 5$ & & $0.9920(0.0078)$ & $0.9919(0.0079)$ & $0.9504(0.0215)$ & $0.9673(0.0189)$ & $0.9905(0.0096)$ \\
\hline & $\# 6$ & & $0.9742(0.0127)$ & $1.0000(<0.0001)$ & $0.9781(0.0135)$ & $0.9855(0.0129)$ & $0.9594(0.0224)$ \\
\hline \multicolumn{2}{|r|}{$F$-test } & & 0.6342 & 0.8435 & 1.0881 & 0.9839 & 0.6524 \\
\hline \multicolumn{2}{|r|}{$P$-value } & & 0.6736 & 0.5185 & 0.3646 & 0.4258 & 0.6597 \\
\hline \multirow{7}{*}{ 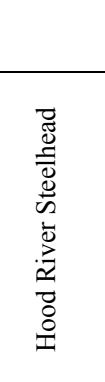 } & & & & $\begin{array}{c}\text { Release to Rkm } \\
234 \\
\end{array}$ & Rkm 234 to 153 & Rkm 153 to 113 & $\mathrm{Rkm} 113$ to 86 \\
\hline & $\# 1$ & & & $0.9745(0.0126)$ & $0.9416(0.0190)$ & $1.0000(<0.0001)$ & $1.0000(<0.0001)$ \\
\hline & $\# 2$ & & & $0.9669(0.0162)$ & $0.9600(0.0190)$ & $0.9891(0.0117)$ & $1.0000(<0.0001)$ \\
\hline & $\# 3$ & & & $0.9732(0.0152)$ & $0.9565(0.0202)$ & $0.9900(0.0120)$ & $1.0000(<0.0001)$ \\
\hline & $\# 4$ & & & $0.9687(0.0156)$ & $0.9429(0.0212)$ & $1.0000(<0.0001)$ & $0.9875(0.0238)$ \\
\hline & $\# 5$ & & & $0.9920(0.0078)$ & $0.9785(0.0140)$ & $0.9945(0.0110)$ & $1.0000(<0.0001)$ \\
\hline & $\# 6$ & & & $0.9430(0.0187)$ & $0.9151(0.0239)$ & $0.9846(0.0138)$ & $0.9620(0.0314)$ \\
\hline \multicolumn{3}{|c|}{ F-test } & & 1.1524 & 1.1703 & 0.3951 & 0.9084 \\
\hline \multicolumn{2}{|r|}{$P$-value } & & & 0.3303 & 0.3211 & 0.8525 & 0.4743 \\
\hline
\end{tabular}


Table E.9. Cormack-Jolly-Seber Estimates of Reach Survivals by Release Site and Tagger for Subyearling Chinook Salmon. F-tests below each release and reach test for homogeneity of survival across taggers. No tests were significant $(\alpha<0.05)$.

\begin{tabular}{|c|c|c|c|c|c|c|c|c|c|c|c|c|c|}
\hline \multirow{3}{*}{$\begin{array}{l}\text { Release } \\
\text { Site }\end{array}$} & \multirow[b]{3}{*}{ Tagger } & \multicolumn{12}{|c|}{ Cormack-Jolly-Seber Survival } \\
\hline & & \multicolumn{2}{|c|}{ Release to Rkm 309} & \multicolumn{2}{|c|}{ Rkm 309 to 275} & \multicolumn{2}{|c|}{ Rkm 275 to 234} & \multicolumn{2}{|c|}{$\mathrm{Rkm} 234$ to 153} & \multicolumn{2}{|c|}{ Rkm 153 to 113} & \multicolumn{2}{|c|}{$\mathrm{Rkm} 113$ to 86} \\
\hline & & Estimate & SE & Estimate & SE & Estimate & SE & Estimate & SE & Estimate & SE & Estimate & SE \\
\hline \multirow{7}{*}{$R_{1}$} & A & $0.8395(5)$ & 0.0177 & $0.9141(4)$ & 0.0147 & $0.9671(5)$ & 0.0104 & $0.9426(4)$ & 0.0138 & $0.9810(4)$ & 0.0086 & $0.9912(4)$ & 0.0061 \\
\hline & $\mathrm{B}$ & $0.8938(2)$ & 0.0141 & $0.9394(3)$ & 0.0115 & $1.0000(2)$ & 0.0044 & $0.9592(2)$ & 0.0102 & $0.9909(2)$ & 0.0052 & $0.9980(3)$ & 0.0023 \\
\hline & $\mathrm{C}$ & $0.8522(4)$ & 0.0165 & $0.9465(2)$ & 0.0114 & $1.0000(2)$ & 0.0000 & $0.9195(5)$ & 0.0142 & $0.9965(1)$ & 0.0034 & $0.9989(2)$ & 0.0045 \\
\hline & $\mathrm{D}$ & $0.8027(6)$ & 0.0187 & $0.9033(5)$ & 0.0155 & $0.9520(6)$ & 0.0124 & $0.9126(6)$ & 0.0168 & $0.9732(5)$ & 0.0106 & $0.9746(6)$ & 0.0101 \\
\hline & $\mathrm{E}$ & 0.9357 (1) & 0.0188 & $0.9562(1)$ & 0.0162 & $1.0000(2)$ & 0.0000 & $0.9782(1)$ & 0.0133 & $0.9822(3)$ & 0.0125 & $1.0000(1)$ & 0.0096 \\
\hline & $\mathrm{F}$ & $0.8910(3)$ & 0.0163 & $0.9016(6)$ & 0.0165 & $0.9879(4)$ & 0.0068 & $0.9500(3)$ & 0.0135 & $0.9722(6)$ & 0.0107 & $0.9787(5)$ & 0.0094 \\
\hline & G & $0.7795(7)$ & 0.0194 & $0.8908(7)$ & 0.0165 & $0.9515(7)$ & 0.0138 & $0.8806(7)$ & 0.0198 & $0.9692(7)$ & 0.0111 & $0.9648(7)$ & 0.0117 \\
\hline \multirow{2}{*}{ All Taggers } & $F$-test & 9.8531 & & 2.9625 & & 6.8130 & & 4.9085 & & 1.1627 & & 2.8155 & \\
\hline & $P$-value & $<0.0001$ & & 0.0068 & & $<0.0001$ & & $<0.0001$ & & 0.3229 & & 0.0097 & \\
\hline \multirow{2}{*}{$\begin{array}{l}\text { Tagger G } \\
\text { Omitted }\end{array}$} & $F$-test & 7.5949 & & 2.6425 & & 7.6624 & & 3.1904 & & 1.1168 & & 2.1171 & \\
\hline & $P$-value & $<0.0001$ & & 0.0215 & & $<0.0001$ & & 0.0070 & & 0.3487 & & 0.0603 & \\
\hline & & \multicolumn{12}{|c|}{ Cormack-Jolly-Seber Survival } \\
\hline \multirow{2}{*}{$\begin{array}{l}\text { Release } \\
\text { Site }\end{array}$} & \multirow[b]{2}{*}{ Tagger } & & & \multicolumn{2}{|c|}{ Release 309 to 275} & \multicolumn{2}{|c|}{$\mathrm{Rkm} 275$ to 234} & \multicolumn{2}{|c|}{$\mathrm{Rkm} 234$ to 153} & \multicolumn{2}{|c|}{ Rkm 153 to 113} & \multicolumn{2}{|c|}{ Rkm 113 to 86} \\
\hline & & & & Estimate & SE & Estimate & SE & Estimate & SE & Estimate & SE & Estimate & SE \\
\hline \multirow{7}{*}{$R_{2}$} & A & & & $0.9924(3)$ & 0.0074 & $0.9807(5)$ & 0.0132 & $0.9511(5)$ & 0.0201 & $0.9925(4.5)$ & 0.0098 & $0.9761(4)$ & 0.0155 \\
\hline & B & & & $0.9704(7)$ & 0.0146 & $0.9874(2)$ & 0.0108 & $0.9619(4)$ & 0.0183 & $0.9814(6)$ & 0.0136 & $0.9842(3)$ & 0.0121 \\
\hline & $\mathrm{C}$ & & & $0.9914(5)$ & 0.0085 & $0.9806(6)$ & 0.0153 & $0.9421(6)$ & 0.0239 & $0.9925(4.5)$ & 0.0118 & $0.9511(7)$ & 0.0226 \\
\hline & $\mathrm{D}$ & & & $0.9918(4)$ & 0.0080 & $0.9867(3)$ & 0.0116 & $0.9637(3)$ & 0.0178 & $1.0000(2)$ & 0.0175 & $0.9671(5)$ & 0.0170 \\
\hline & $\mathrm{E}$ & & & $1.0000(1.5)$ & 0.0071 & $1.0000(1)$ & 0.0071 & $0.9750(2)$ & 0.0247 & $1.0000(2)$ & 0.0084 & $1.0000(1.5)$ & 0.0072 \\
\hline & $\mathrm{F}$ & & & $1.0000(1.5)$ & 0.0000 & 0.9819 (4) & 0.0129 & $0.9902(1)$ & 0.0097 & $1.0000(2)$ & 0.0000 & $1.0000(1.5)$ & 0.0000 \\
\hline & G & & & $0.9795(6)$ & 0.0117 & $0.9785(7)$ & 0.0142 & $0.9226(7)$ & 0.0237 & $0.9777(7)$ & 0.0137 & $0.9592(6)$ & 0.0181 \\
\hline \multirow{2}{*}{ All Taggers } & $F$-test & & & 1.3856 & & 0.3499 & & 1.1805 & & 0.6034 & & 1.6362 & \\
\hline & $P$-value & & & 0.2159 & & 0.9103 & & 0.3130 & & 0.7279 & & 0.1326 & \\
\hline \multirow{2}{*}{$\begin{array}{l}\text { Tagger G } \\
\text { Omitted }\end{array}$} & $F$-test & & & 1.5552 & & 0.3728 & & 0.7505 & & 0.4070 & & 1.7774 & \\
\hline & $P$-value & & & 0.1691 & & 0.8676 & & 0.5856 & & 0.8443 & & 0.1138 & \\
\hline
\end{tabular}




\section{E.6 References}

Li T and JJ Anderson. 2009. "The vitality model: A way to understand population survival and demographic heterogeneity." Theoretical Population Biology 76(2):118-131.

Skalski JR, GE Johnson, and TJ Carlson. 2010a. Compliance Monitoring of Juvenile Yearling Chinook Salmon and Steelhead Survival and Passage at The Dalles Dam, Spring 2010. Summary Report PNNL-19819, Pacific Northwest National Laboratory, Richland, Washington.

Skalski JR, GE Johnson, and TJ Carlson. 2010b. Compliance Monitoring of Juvenile Subyearling Chinook Salmon Survival and Passage at The Dalles Dam, Summer 2010. Summary Report PNNL-20042, Pacific Northwest National Laboratory, Richland, Washington. 
PNNL-20835

\section{Distribution}

No. of

Copies

\section{OFFSITE}

15 Paper copies and PDF

Brad Eppard

USACE District, Portland

CENWP-PM-E

333 SW 1st Avenue (R. Duncan Plaza)

Portland, OR 97204-3495

21 Paper copies and PDF

Gene Ploskey

390 Evergreen Drive

P.O. Box 241

North Bonneville, WA 98639
No. of

Copies

\section{ONSITE}

3 Pacific Northwest National Laboratory

KD Ham (Paper and PDF)

K6-85

DR Geist (Paper and PDF)

K6-85

PNNL Library (Paper and PDF) 


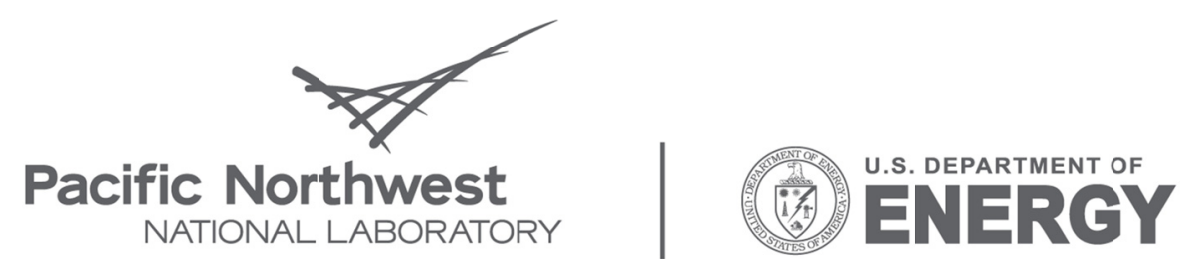

Proudly Operated by Battelle Since 1965

902 Battelle Boulevard

P.O. Box 999

Richland, WA 99352

1-888-375-PNNL (7665)

www.pnl.gov 